\title{
LUÍS POMPEO MARTINS
}

\section{A CIDADE}

EM MOVIMENTO:

A VIA EXPRESSA E O PENSAMENTO URBANISTICO NO SÉCULO XX

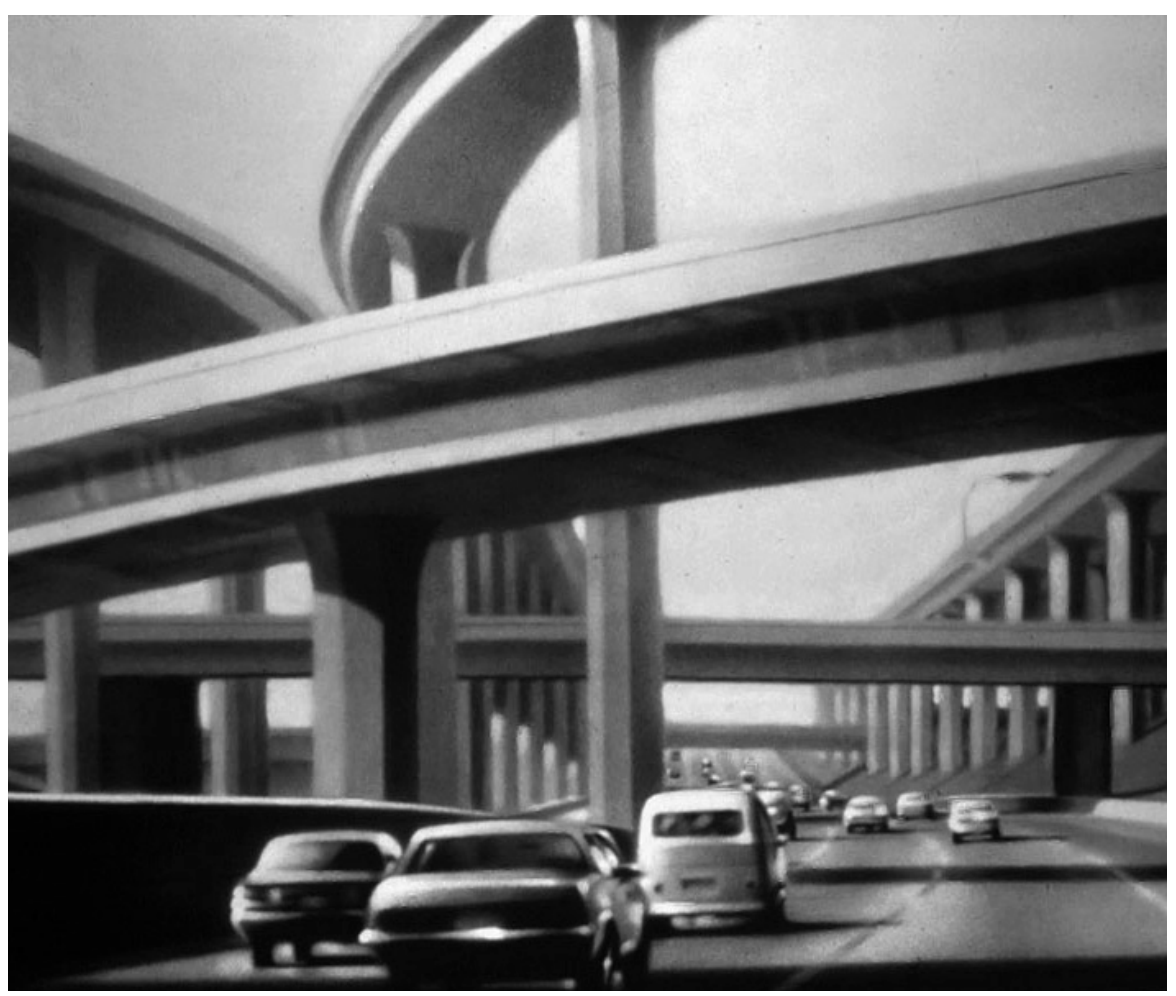

SÃO PAULO, 2017 



\section{A CIDADE EM MOVIMENTO: \\ A VIA EXPRESSA E O PENSAMENTO URBANÍSTICO NO SÉCULO XX}

ORIENTAÇÃO: LUÍS ANTÔNIO JORGE

Dissertação apresentada à

Faculdade de Arquitetura e Urbanismo da Universidade de São Paulo para a obtenção do título de Mestre em Ciências,

Programa de Arquitetura e Urbanismo

Área de concentração:

Projeto, Espaço e Cultura

SÃO PAULO, 2017 
Autorizo a reprodução e divulgação total ou parcial deste trabalho, por qualquer meio convencional ou eletrônico, para fins de estudo e pesquisa, desde que citada a fonte.

E-mai: luis.pompeo@gmail.com

Martins, Luís Pompeo

M379c A cidade em movimento: a via expressa e o pensamento urbanístico no século xx / Luis Pompeo Martins ; orientador Luís Antônio Jorge. - São Paulo, 2017. $200 \mathrm{p}$.

Dissertação (Mestrado) - Faculdade de Arquitetura e Urbanismo da Universidade de São Paulo. Área de concentração: Projeto, Espaço e Cultura

1. Urbanização. 2. Vias Expressas. 3. Espaço Público. 4. Mobilidade Urbana. 5. Espaço Urbano. 6. Modernização. 7. Infraestrutura de Transportes. I. Jorge, Luís Antônio, orient. II. Título. 


\section{LUÍS POMPEO MARTINS}

A CIDADE EM MOVIMENTO:

A VIA EXPRESSA E O

PENSAMENTO URBANÍSTICO

NO SÉCULOXX

Dissertação apresentada à

Faculdade de Arquitetura e Urbanismo da

Universidade de São Paulo para a obtenção

do título de Mestre em Ciências,

Programa de Arquitetura e Urbanismo

Área de concentração:

Projeto, espaço e cultura

APROVADO EM:

BANCA EXAMINADORA:

PROF. DR.:

ASSINATURA

INSTITUIÇÃO:

PROF. DR.:

ASSINATURA

INSTITUIÇÃO:

PROF. DR.:

ASSINATURA

INSTITUIÇÃO: 



\title{
AGRADECIMENTOS
}

\author{
À Universidade de São Paulo, que mais uma vez me acolheu. \\ À Coordenação de Aperfeiçoamento de Pessoal de Nível Superior (CAPES) \\ pelo apoio à pesquisa. \\ Ao orientador, Luís Antônio Jorge, principal interlocutor destas reflexões, debatidas \\ desde 2009 ao longo do desenvolvimento do meu trabalho final de graduação, intitulado \\ "Automóvel: Barreiras e Transposições em São Paulo". \\ Às professoras Klara Kaiser - importante interlocutora durante todo o processo - e \\ Maria Cristina Leme pelas contribuições na banca de qualificação. Aos professores \\ Regina Meyer, Vera Pallamin, Luiz Recamán, Ana Barone, e Andreína Negriello \\ que, através das disciplinas contribuíram diretamente para o desenvolvimento da disserta- \\ ção. Aos professores e alunos colegas durante as atividades docentes do programa PAE. \\ À Camila Bachichi pelo projeto gráfico desta dissertação. \\ Ao Guilherme Wisnik, curador da X Bienal de Arquitetura de São Paulo, que, em \\ 2013, deu espaço para que pudesse dar continuidade às inquietudes do TFG; bem como \\ a todos os colegas da equipe de curadoria, em especial aos participantes da exposição \\ "Carrópolis": Denis Joelsons, Francesco Perrotta-Bosch, Luiz Fabio Anto- \\ nioli, Damien Murat.
}

Aos meus "veteranos" Marco Lagonegro e Pablo Hereñú pela importante interlocução - tanto em texto quanto em diálogo - junto às questões do "rodoviarismo".

Aos amigos-interlocutores, que em muito contribuíram para o amadurecimento destas ideias: Rafael Urano, Luiz Florence, Lucas Girard, Moreno Zaidan Garcia, Guilherme Pianca, Roberto Rusche, Luís Felipe Abbud, Santiago D'Ávila e Ricardo Gusmão. Ao José Paulo Gouvêa pelo importante incentivo.

Aos amigos contemporâneos na pós-graduação: André Villas Boas, Tiago Oakley, Marina Malagolini, Martin Benavidez. A todos os amigos e familiares que se solidarizaram ao longo do processo.

Ao André Sant'anna da Silva, Gabriel Manzi, Ivo Magaldi, Anelise Bertolini, João Miguel Silva, Leonardo Klis, Mario do Val, e a todo o pessoal da 23SUL, que me cobriu durante minha ausência e sempre apoiou a pesquisa. 
Ao irmão e colega de FAU, Eduardo Pompeo, que em sua cruzada em favor dos espaços públicos na gestão Haddad me apontou pela primeira vez o jaywalker de Peter Norton, uma contribuição inestimável ao trabalho.

À Aída Pompeo, que além de mãe, me apresentou em 2006 à fascinante visão de modernidade de Marshall Berman, base fundamental de toda a pesquisa do mestrado e desta dissertação.

Ao João Carlos Martins, o "Pompai", pela visão de mundo e generosidade de sempre. À Fernanda Kalena, pelo amor e companheirismo incondicionais (e pela revisão do texto!), o meu muito obrigado. 




\section{RESUMO}

MARTINS, Luís Pompeo. A cidade em movimento: a via expressa e o pensamento urbanístico no século XX. 2017. 190p. Dissertação de Mestrado - Faculdade de Arquitetura e Urbanismo, Universidade de São Paulo, São Paulo, 2017.

Este trabalho apresenta uma visão sobre a conceituação e o desenvolvimento tipológico das vias expressas urbanas durante a primeira metade do século XX. Partindo do entendimento das condições que determinaram a sua invenção para, em seguida, analisar o desenvolvimento técnico dessas infraestruturas nos campos da engenharia e do urbanismo. As promissoras possibilidades que as novas velocidades do automóvel ofereciam no início do século entraram imediatamente em conflito com a estrutura física, histórica e social da cidade tradicional. Para que fosse possível mediar tal embate, seria necessário um novo pacto social do uso da rua que segregasse pessoas e veículos, separando-os entre a calçada e o leito carroçável. É a partir da regulamentação do espaço viário dos centros urbanos - concebida pelos primeiros engenheiros de tráfego, nos Estados Unidos, entre as décadas de 1910 e 1920 - que a rua deixa de ser primordialmente espaço público para se tornar infraestrutura, dedicada ao transporte urbano de pedestres e motoristas. No entanto, a partir da década de 1930, devido ao crescimento dos acidentes de trânsito e dos congestionamentos, tornou-se necessário o desenvolvimento de um novo tipo de infraestrutura, que contemplasse as necessidades do carro, permitindo-lhe trafegar em velocidade com segurança. Era preciso construir um espaço absolutamente segregado, sem nenhum tipo de obstáculo, numa ruptura radical entre suas pistas e o restante da cidade. É dessa forma que surge a via segregada de acesso limitado - a via expressa -, um dos momentos mais contundentes da ideologia rodoviarista no espaço urbano, transformando radicalmente sua estrutura física e social. Ao longo do desenvolvimento da via expressa como tipologia por diversos profissionais, na primeira metade do século $X X$, sua relação com o espaço urbano é enfrentada de forma dialética. Enquanto algumas propostas negavam a cidade tradicional na sua busca por segregação através de novas formas de urbanismo, outras a enfrentaram, cortando a cidade com suas pistas, tornando os centros urbanos acessíveis ao automóvel. A partir da segunda metade do século $X X$, a síntese se estabelece. Ambas as formas de relação entre rodovia e cidade - de negação e enfrentamento - prosperam, tornando-se parte da realidade inexorável de uma nova condição urbana. Por fim, em contrapartida, a via expressa é analisada de forma abstrata, através da leitura de aspectos culturais, do conceito de "progresso" como um mito contemporâneo, bem como as noções de "lugar" e "não-lugar", à luz das condições impostas pela modernidade do capitalismo pós-industrial.

Palavras-chave: Urbanização, Vias Expressas, Espaço Público, Mobilidade Urbana, Espaço Urbano, Modernização, Infraestrutura de Transportes 



\section{ABSTRACT}

MARTINS, Luís Pompeo. A cidade em movimento: a via expressa e o pensamento urbanístico no século XX. 2017. 190p. Dissertação de Mestrado - Faculdade de Arquitetura e Urbanismo, Universidade de São Paulo, São Paulo, 2017.

This paper presents a vision on the conceptualization and the typological development of urban expressways during the first half of the 20th century. Starting from the understanding of the conditions that determined its invention, and furtherly, analyzing the technical development of these infrastructures in the fields of engineering and urbanism. The promising possibilities offered by the automobile at the turn of the century immediately clashed with the physical, historical, and social structure of the traditional city. In order to mediate such a conflict, a new social pact regarding street use would be needed, managing the segregation between people and vehicles. In the United States, between the 1910s and 1920s, the street regulation conceived by the first traffic engineers transformed the public space of the street into infrastructure, dedicated almost exclusively to the urban transportation of Pedestrians and drivers. However, since the 1930s, due to the increase in traffic accidents and congestion, it became necessary to develop a new type of infrastructure, which would meet the needs of the car, allowing it to travel safely at a proper speed. It has become necessary the construction of an entirely segregated space to the car, rid of any kind of obstacle, in a radical rupture between its tracks and the rest of the city. The urban limited-access highway - also known as the "expressway" - emerges along this scenario, being one of the most striking moments of the car culture in urban space, radically transforming its physical and social structure. Throughout the development of the expressway as typology by several professionals, in the first half of the twentieth century, its relationship with urban space is dialectically confronted. While some proposals "denied" the traditional city through new forms of road design and urbanism, others "confronted" it, cutting through the city with its tracks, making urban centers accessible to the automobile. From the second half of the twentieth century, synthesis is established. Both forms of relationship between highway and city - of denial and confrontation - thrive, becoming part of the inexorable reality of a new urban condition. Finally, the expressway is analyzed in a more abstract approach, through the reading of some of its cultural aspects. The concept of "progress" as a contemporary myth is also mentioned, as well as the notions of "place" and "non-place", regarding the conditions imposed by the modernity of post-industrial capitalism.

Keywords: Urbanization, Expressways, Public Space, Urban Mobility, Urban Space, Modernization, Transportation Infrastructure. 


\section{SUMÁRIO}

INTRODUÇÃO

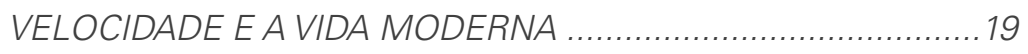

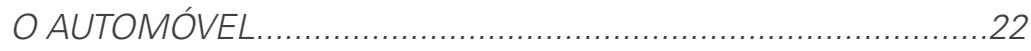

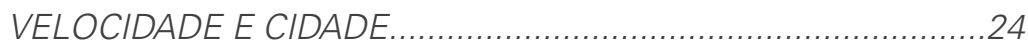

1.0 NOVO PACTO SOCIAL DA RUA: A SEGREGAÇÃO COMO MEDIAÇÃO DO CONFLITO 29

1. 1. O HOMEM ATRAVESSANDO A RUA..............................................31

1.2. O CONFLITO ENTRE O AUTOMÓVEL E A RUA

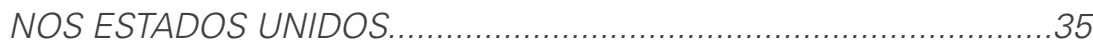

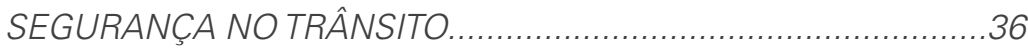

CONGESTIONAMENTOS E ENGENHEIROS DETRÁFEGO.........41

LOBBY AUTOMOBILÍSTICO: POR MAIS ESPAÇO VIÁRIO...........44

2. A RODOVIA NEGANDO A CIADADE 51

2. 1. A CRISE DA CIDADE TRADICIONAL.................................................53

2.2. AS RODOVIAS PARA AUTOMÓVEIS E SEU

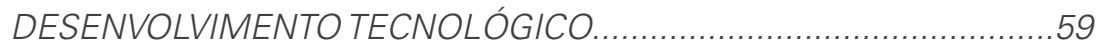

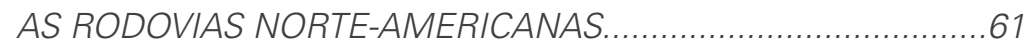

AS RODOVIAS EUROPEIAS..................................................64

AUTOSTRADAS ITALIANAS.......................................................65

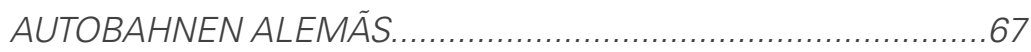

2.3. FUGERE URBEM: O URBANISMO A PARTIR DA RODOVIA...........70

O PLANEJAMENTO REGIONAL DA RPAA .............................70

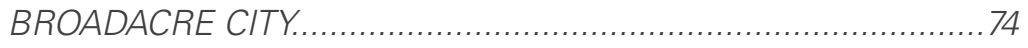

A MODERNIDADE PASTORAL DE LE CORBUSIER ..................76

2.4. AS PARKWAYS DE NOVA IORQUE: SÍNTESE DA

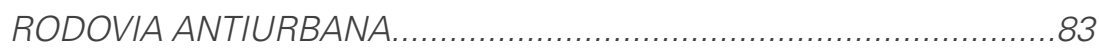

3. A RODOVIA ENFRENTANDO A CIDADE 89

3. 1. A CIRCULAÇÃO NA CIDADE INDUSTRIAL...................................91 
3.2. AS FORMULAÇÕES RODOVIARISTAS URBANAS .........................99

LE CORBUSIER ENFRENTANDO CIDADE TRADICIONAL.......... 105

A UTOPIA DO LOBBY AUTOMOBILÍSTICO............................ 110

3.3. VIAS EXPRESSAS URBANAS: CATALIZADORES DO

URBANISMO FUTURO NORTE-AMERICANO ........................... 114

A CENTRAL ARTERY DE BOSTON.................................. 122

AS VIAS ELEVADAS DE NOVA IORQUE ............................... 126

4. A RODOVIA VENCENDO A CIDADE

4.1. VIA EXPRESSA COMO PROJETO NACIONAL

NORTE-AMERICANO....

O RELATÓRIO TOLL ROADS AND FREE ROADS, 1939 134

O RELATÓRIO INTERREGIONAL HIGHWAYS, 1944. 138

AMERICAN ASSOCIATION OF STATE HIGHWAY

OFFICIALS (AASHO)...... 141

LEGISLAÇÃO FEDERAL. 143

4.2. O TRÂNSITO PEDE PASSAGEM: A VIA EXPRESSA NO NOVO PARADIGMA URBANÍSTICO. 144

TURNPIKES: AS RODOVIAS PEDAGIADAS..... 148

FEDERAL AID HIGHWAY ACT, 1956. 150

4.3. A CULTURA DO AUTOMÓVEL NO SEGUNDO PÓS-GUERRA. 153

\section{APONTAMENTOS PARA UMA PAUTA} DO URBANISMO CONTEMPORÂNEO

5.1. O MITO DO PROGRESSO. 163

5.2. VIA EXPRESSA E A CRISE DO CONCEITO DE "CIDADE".. 170

5.3. VIA EXPRESSA COMO SOLUÇÃO PARA O TRÂNSITO. 178

5.4. PERSPECTIVAS. 181 

|II/ INTRODUÇÃO 



\section{VELOCIDADE E A VIDA MODERNA}

Com a ascensão da classe burguesa ao poder o homem muda sua relação com o tempo. Fatores naturais como a duração do dia e da noite, as estações do ano e as épocas de colheita deixam de ditar o ritmo da vida dos homens, que passa a ser determinada pelas novas relações sociais entre eles estabelecida. Nessa nova ordem social, as relações de trabalho pautam a vida humana através dos processos produtivos ${ }^{1}$, que exigem ritmos cada vez mais pulsantes de homens e mulheres. Até a revolução burguesa, os privilégios de classe eram obtidos de forma hereditária. A burguesia, no entanto, passou a se afirmar a partir de suas próprias ações. Como descreveu Marshall Berman: "Eles produziram novas imagens e paradigmas, vívidos, da vida boa como a vida de ação. Provaram que é possível, através da ação organizada e concertada, realmente mudar o mundo" ${ }^{2}$.

A partir desse ímpeto transformador, imprimiu-se um novo ritmo para a sociedade, baseado no conceito de produtividade. Partindo do princípio de que o valor de uma mercadoria se estabelece a partir do trabalho socialmente necessário para a sua produção ${ }^{3}$ - e que a quantidade de trabalho é medida através do tempo -, maiores velocidades resultam em aumento da produtividade das horas trabalhadas. Mais do que isso, o aumento de produtividade é fundamental para a sobrevivência dos negócios ${ }^{4}$, transformando o processo produtivo em uma corrida contra o relógio, como novamente coloca Berman:

"Sob pressão, todos os burgueses, do mais humilde ao mais poderoso, são forçados a inovar, simplesmente para manter o seu negócio e a si mesmos à tona; quem quer que deixe de mudar, de maneira ativa, tornar-se-á vítima passiva das mudanças draconianamente impostas por aqueles que dominam

1 "O capital cria a sociedade burguesa e a apropriação universal da natureza, bem como o próprio vinculo social entre os membros da sociedade. Daí decorre a grande influência civilizatória do capital; sua produção de um estágio da sociedade em comparação com qual todos os estágios anteriores parecem meros desenvolvimentos locais da humanidade e idolatria da natureza. Pela primeira vez, a natureza se torna para a humanidade mero objeto, mera questão de utilidade, cessando de ser reconhecida como um poder em si mesma; e a descoberta teórica de suas leis autônomas parece somente um artifício destinado à subjugá-las às necessidades humanas" (MARX, citado por HARVEY, 1993: p.106)

2 BERMAN, 1986: p.92

3 "Um valor-de-uso ou um bem só possui, portanto, valor, porque nele está corporificado, materializado, trabalho humano abstrato. Como medir a grandeza do seu valor? Por meio da quantidade da "substância criadora de valor" nele contida, o trabalho. A quantidade de trabalho, por sua vez, mede-se pelo tempo de sua duração, e o tempo de trabalho, por frações de tempo, como hora, dia etc. (...) O que determina a grandeza do valor, portanto, é a quantidade de trabalho socialmente necessário ou o tempo de trabalho socialmente necessário para a produção do valor-de-uso". (MARX, 1989: p. 45-46).

4 "A grandeza do valor de uma mercadoria permaneceria, portanto, invariável, se fosse constante o tempo de trabalho requerido para a sua produção. Mas este muda com qualquer variação na produtividade (força produtiva) do trabalho. A produtividade do trabalho é determinada pelas mais diversas circunstâncias, entre elas a destreza média dos trabalhadores, o grau de desenvolvimento da ciência e sua aplicação tecnológica, a organização social do processo de produção, o volume e a eficácia dos meios de produção e as condições naturais" (Ibid.: p. 46) 
o mercado, ou seja, 'não pode subsistir sem constantemente revolucionar os meios de produção". A intensa e incansável pressão no sentido de revolucionar a produção tende a extrapolar, impondo transformações também naquilo que Marx chama de 'condições de produção', 'e com elas, todas as condições e relações sociais." 6

Grande aliada do capital no processo produtivo, a tecnologia passava a ajudar os homens a encurtar distâncias, revolucionando as formas de deslocamento através das grandes velocidades obtidas. A ferrovia para locomotiva a vapor, inventada no Reino Unido, em 1814, transformou radicalmente os parâmetros de velocidade do mundo moderno, imprimindo novos padrões de deslocamento terrestre. O fascínio com a velocidade da ferrovia foi imediato, já que ela transformava as relações do homem com o território e com o tempo, como mostra o depoimento de Jules Janin, em 1842, após uma viagem entre Saint Étienne e Lyon:

"Andar tão depressa, atravessar tantas montanhas, ultrapassar os precipícios, tudo isso por causa de duas linhas de ferro paralelas! Lembre-se de que o carro, logo que sai, já chegou. Podemos nos vangloriar de termos feito a viagem mais surpreendente que existe hoje" ${ }^{7}$.

Fica claro o fascínio do homem moderno com as possibilidades ampliadas pela máquina. A defesa da tecnologia aos poucos se torna a tônica do discurso da época, aparecendo no imaginário popular e na literatura. Em outro depoimento, o jornalista francês Misard relata:

"Uma campainha toca a partida. A Máquina põe-se em andamento. Desloca-se inicialmente com lentidão, mas logo começa a ganhar velocidade, arrebatando-se depois, para logo voar como se fugisse do ruído da carruagem que atrás de si arrasta. Corre tão depressa quanto a mais tenaz impaciência do homem. Transporta seu corpo com uma rapidez semelhante à do pensamento humano" ${ }^{8}$

O período de passagem do século XIX para o século XX é marcado por uma quebra de paradigma do mundo moderno, onde esse entusiasmo se intensifica e alguns homens passam a abraçar sem medo as emoções contraditórias da modernidade. O "temor respeitoso e exaltação impregnados um senso de horror" dos movimentos e pressões da moderna vida econômica: de sua incansável e insaciável demanda de crescimento e progresso" ${ }^{10}$. O autor cita Rimbaud", que afirmava: "é preciso ser absolutamente moderno" para que seja possível enfrentar um mundo em constante transformação. A essa postura positiva em relação à modernidade Berman dá o nome de

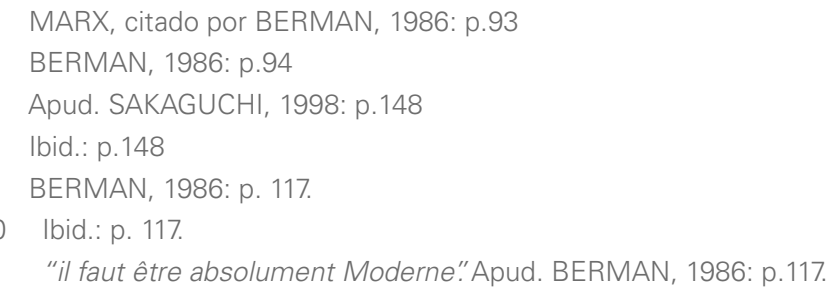


"modernolatria". Não à toa, Giulio Carlo Argan agrupa sob o "termo genérico" ${ }^{12}$ de "Modernismo" os artistas que "propõem-se a interpretar, apoiar e acompanhar o esforço progressista, econômico-tecnológico, da civilização industrial" ${ }^{13}$. Segundo o autor, eles buscariam “interpretar a 'espiritualidade' que se dizia (com um pouco de ingenuidade, um pouco de hipocrisia) inspirar e redimir o industrialismo" ${ }^{14}$.

Talvez uma das vanguardas artísticas mais emblemáticas do espírito da modernolatria desse período seja o Movimento Futurista, marcado pelo seu manifesto publicado no jornal Parisiense Le Figaro, em 1909, escrito pelo poeta italiano Filippo Tommaso Marinetti. Nele, fica evidente o desejo de assimilar por completo todas as forças contraditórias da modernidade, exaltando o espírito em movimento, revolucionário, em constante transformação, valorizando a obsolescência em seus aspectos mais destrutivos, em nome do que está por vir ${ }^{15}$ :

"Não há mais beleza, a não ser na luta. Nenhuma obra que não tenha um caráter agressivo pode ser uma obra prima." 16

"Nós cantaremos as grandes multidões agitadas pelo trabalho (...); cantaremos as marés multicores e polifônicas das revoluções nas capitais modernas (...)" 17

"Os mais velhos dentre nós têm trinta anos: resta-nos, portanto, pelo menos uma década, para cumprir nossa obra. Quando tivermos quarenta anos, outros homens mais jovens e mais válidos que nós, atirar-nos-ão ao cesto, como manuscritos inúteis. - Nós o desejamos!" 18

"A arte, de fato, não pode ser mais que violência, crueldade e injustiça" 19

Dentro esse espírito impetuoso e aguerrido, uma pavorosa exaltação da velocidade surge como elemento-síntese dos anseios futuristas. O homem moderno, pressionado para ser mais eficiente e mais rápido, enxerga na velocidade proporcionada pela máquina uma poderosa aliada. Caberia assim ao movimento futurista exaltá-la eloquentemente em sua totalidade, sem deixar de lado sua face mórbida, pelo contrário, fascinando-se com a iminente proximidade da morte:

"Nós afirmamos que a magnificência do mundo enriqueceu-se de uma beleza nova: a beleza da velocidade" ${ }^{20}$.

12 Palavras utilizadas pelo próprio autor.

13 ARGAN, 1992: p. 185.

14 Ibid.: p.185.

15 Como explica Argan, "Por volta de 1910, quando ao entusiasmo pelo progresso industrial sucede-se a consciência da transformação em curso nas próprias estruturas da vida e da atividade social, formar-se-ão no interior do 'Modernismo' as 'vanguardas' artísticas preocupadas não mais apenas em modernizar ou atualizar, e sim revolucionar radicalmente as modalidades e finalidades da arte". (Ibid.: p.185)

16 MARINETTI, in. BERNARDINI, 1980: p. 34

17 Ibid.: p. 34

18 Ibid.: p. 36

19 Ibid:: p. 36

20 Ibid.: p. 34 
"(...) o tempo e o espaço morreram ontem. Nós já estamos vivendo no absoluto, pois já criamos a eterna velocidade onipresente" ${ }^{21}$

"E nós corríamos, esmagando nas soleiras das portas os cães de guarda que se arredondavam debaixo de nossos pneus ardentes. A morte, domesticada, ultrapassava-me em cada curva, para oferecer-me a pata com graça." 22

Posteriormente, Marinetti publica mais um manifesto, intitulado "A Nova Religião-Moral da Velocidade", transcendendo a velocidade ao nível do sublime, do divino;

"Se rezar significa comunicar-se com a divindade, correr à grande velocidade é uma oração. Santidade da roda e dos trilhos" ${ }^{23}$;

traduzindo essa nova condição em forma, em estética;

"A velocidade dá finalmente à vida humana uma das características da divindade: a linha reta" ${ }^{24}$;

dramatizando ainda mais o seu aspecto dúbio, sua liberdade ameaçadora;

"Correr, correr, correr, voar, voar. Perigo perigo perigo perigo perigo à direita à esquerda sob sobre dentro fora cheirar respirar beber a morte" ${ }^{25}$;

até que na frase final do manifesto o autor apela a todos que abracem a modernidade por completo:

"Somente a velocidade poderá matar o maligno luar, nostálgico, sentimental, pacifista, neutro. Italianos, sejam velozes e serão fortes, otimistas, invencíveis, imortais!" ${ }^{26}$.

\section{O AUTOMÓVEL}

Dentro da apologia à velocidade e à tecnologia, os futuristas demonstram apreço especial ao automóvel. Fruto do desenvolvimento de diversos componentes tecnológicos ao longo do século XIX, como o motor a combustão e o pneu, o veículo automotor se tornou um produto comercializado a partir da década de 1890, na Europa e nos Estados Unidos. Surge de forma intensa uma enorme quantidade de organizações dispostas a construí-lo: 167 na França, 35 na Alemanha, 112 na Inglaterra, 11 na Itália e 215 nos Estados Unidos ${ }^{27}$.

21 Ibid:: p. 34

22 Ibid.: p. 32

23 Ibid.: p. 213

24 Ibid.: p. 212

25 MARINETTI, in. BERNARDINI, 1980: p. 215

26 Ibid.: p. 217

27 GIUCCI, 2004: p. 13. Segundo o autor, em momento posterior a automatização será responsável pela drástica diminuição de fabricantes de automóvel ao longo do século XX: Nos Estados Unidos restaram 12 fabricantes em 1941, 22 na Grã-Bretanha em 1930, 13 na Alemanha em 1936. 
De início, o automóvel era uma máquina excêntrica, - alvo da incredulidade de muitos - e tornou-se interesse de consumo da burguesia. Mais do que um meio de transporte, o automóvel triunfou na Europa como esporte, através da organização de corridas - que se aproximam do que seriam hoje os ralis -, porém com velocidades ainda muito limitadas. Contudo, a tecnologia evoluiu rapidamente, possibilitando já em 1900 a construção de veículos automotores que beirassem os $100 \mathrm{~km} / \mathrm{h}$. Dotado de extraordinária vitalidade, o automóvel passou rapidamente a ser visto como uma exigência do mundo moderno. Ele era capaz de propiciar a economia de tempo, tão fundamental ao aumento de produtividade, necessária ao homem moderno. Ele se distinguia dos outros meios de transporte - como bondes, bicicletas e veículos de tração animal - pelas suas possibilidades de aceleração, sendo, portanto, um sinônimo de velocidade. Como afirmou Ray W. Sherman, executivo da indústria automobilística norte-americana, "o carro a motor foi inventado para que o homem pudesse ir mais rápido" e "a maior qualidade inerente do automóvel é a velocidade" ${ }^{28}$.

Mas o automóvel ia além. Mais do que um simples meio de transporte, ele propiciava a velocidade de uma máquina terrestre ao indivíduo. Esse fato seria especialmente importante ao homem moderno, pois, como afirma o filósofo Georg Simmel: "os problemas fundamentais da vida moderna provêm de que o indivíduo deseja a qualquer preço, diante das forças esmagadoras da sociedade (...) preservar a autonomia e a originalidade de sua experiência" ${ }^{29}$. Tal desejo é parte elementar do espírito futurista. Como homens modernos, eles buscam no automóvel a ferramenta ideal para possibilitar uma experiência verdadeiramente moderna.

Em "A Nova Religião-Moral da Velocidade", a divinização da velocidade coloca o automóvel como elemento de adoração, objeto transformado em fetiche ${ }^{30}$ :

"A embriaguez das grandes velocidades em automóvel não é mais que a alegria de sentir-se fundido com a única divindade. Os esportistas são os primeiros neófitos dessa religião. Próxima destruição das casas e das cidades, para formar grandes agrupamentos de automóveis e de aeroplanos." ${ }^{31}$

"LOCAIS HABITADOS PELO DIVINO: (...) a praça da ópera de Paris (...) os circuitos de automóveis (...) os motores a explosão e os pneumáticos de um automóvel são divinos. As bicicletas e motocicletas são divinas. A gasolina é divina. (...). Alegria de passar da $3^{a}$ para a $4^{a}$ marcha. Alegria de apertar o acelerador, pedal ressoante da velocidade musical." 32

Assim como balas disparadas por armas de fogo, automóveis eram igualmente rápidos e mortais. Essa próxima relação entre velocidade e perigo dá a tônica ao primeiro manifesto futurista, onde o automóvel ocupa papel principal:

28 "the motor car was invented so that man could go faster"; "the major inherent quality of the automobile is speed". Citado por NORTON, 2008: p. 99.

29 SIMMEL, in. CHOAY, 2005: p. 330. O título em português também já foi traduzido para "A Metrópole e a Vida Mental".

30 O termo aqui utilizado remete ao conceito de "fetichismo" que Marx aborda em "O Capital", onde um objeto criado pelo homem acaba adquirindo características sobrenaturais que fogem ao seu controle.

31 MARINETTI, in. BERNARDINI, 1980: p 213.

32 Ibid:: p 214. 
"Mas, enquanto escutávamos o extenuado murmúrio de orações do velho canal e o estralar dos ossos dos palácios moribundos sobre as barbas de úmida verdura, nós escutamos, subitamente, rugir sob as janelas os automóveis famélicos.

- Vamos, disse eu: vamos amigos! Partamos! Finalmente a mitologia e o ideal místico estão superados. Nós estamos prestes a assistir ao nascimento do centauro e logo veremos voar os primeiros anjos! Será preciso sacudir as portas da vida para experimentar seus gonzos e ferrolhos! Partamos! Não há nada que iguale o resplendor da espada vermelha do sol que esgrima pela primeira vez nas nossas trevas milenares!...

Aproximamo-nos das três feras bufantes, para apalpar amorosamente seus tórridos peitos. Eu estendi-me em meu carro, como cadáver no leito, mas logo em seguida ressuscitei sob o volante, lâmina de guilhotina que ameaçava meu estômago." 33

O fascínio pelo automóvel descrito por Marinetti demonstra de modo contundente a força do seu caráter simbólico, ou como afirmaria Roland Barthes, o automóvel é a "catedral gótica dos nossos tempos" ${ }^{34}$. Eduardo Vasconcellos sintetiza as relações mencionadas entre homem e automóvel em quatro visões distintas. Dentre elas, a relação psicológica exalta o prazer em dirigir um veículo em velocidade, como vemos no discurso futurista. As possibilidades que o veículo automotivo trouxe ao indivíduo transcendem o ato de dirigir em um ato estético ${ }^{35}$.

Ao proporcionar velocidade ao indivíduo, a simbologia do automóvel também se torna particularmente adequada aos ideais norte-americanos, sobretudo pela liberdade que é possibilitada ao indivíduo através do automóvel. Por conta dessa afinidade, a cultura do automóvel se desenvolveria ao longo do século XX nos Estados Unidos como em nenhum outro país. Para Roy Chaplin, presidente da Hudson Motor Car Company, os norte-americanos são uma "raça de pessoas independentes", cujos "ancestrais vieram a esse país em nome da liberdade e aventura", e "o automóvel satisfaz esses instintos" ${ }^{36}$.

\section{VELOCIDADE E CIDADE}

As promissoras possibilidades que as novas velocidades ofereciam acabavam por entrar em conflito com a cidade tradicional, cujas formas ainda se baseavam nas necessidades e escala do homem. Os longos e rápidos deslocamentos passam a entrar em conflito com as demais atividades urbanas. Ninguém estava satisfeito. Para se transportar com rapidez pela cidade - demanda sempre crescente nos grandes centros urbanos - seriam necessárias novas formas urbanas, em escala nunca antes vista, afastando-se cada vez mais do tempo do homem, em direção ao tempo da máquina.

33 MARINETTI, in. BERNARDINI, 1980: p. 32.

34 VASCONCELLOS, 1996: p. 105.

35 Ibid.: p. 106.

36 "are a race of independent people"; "ancestors came to this country for the sake of freedom and adventure,"; "the automobile satisfies these instincts."Apud. NORTON, 2008: p. 205. 
Da mesma forma como a cidade tradicional não mais se adequava às necessidades dos rápidos deslocamentos, usos corriqueiros da rua também passavam a ser impossibilitados pela velocidade urbana. Para que esse conflito fosse pacificado, seria necessário um novo pacto social do uso desse espaço, que segregasse pessoas e veículos, separando a calçada do leito carroçável. A rua deixaria de abrigar diversas atividades urbanas para se tornar exclusivamente espaço de deslocamento, infraestrutura de circulação de veículos. Quando muito, pessoas teriam seu lugar restrito às calçadas, que também, aos poucos, passariam a primar pelos os deslocamentos humanos. Pessoas nas ruas se tornariam meros pedestres.

Em última instância, em nome da velocidade o automóvel necessitaria de um espaço exclusivo, onde o veículo não pudesse encontrar nenhum tipo de obstáculo, numa separação absolutamente drástica de qualquer uma das atividades urbanas. Era preciso, antes de tudo, possibilitar ao maior número de indivíduos deslocamentos, o mais rápido possível. É dessa forma que a via segregada de acesso limitado se expressa como o momento mais contundente da ideologia rodoviarista na cidade, isolando o automóvel do conflito com todas as demais atividades urbanas. Até onde fomos capazes de abrir mão de outras necessidades humanas na cidade em nome do deslocamento individual em velocidade?

Mesmo essa separação sendo desejável não apenas aos automóveis, a construção dessas infraestruturas teve um alto preço a ser pago pela cidade como um todo. Para que os automóveis pudessem circular livremente nas freeways, os espaços públicos circundantes foram prejudicados, muitas vezes afetando bairros inteiros, ou mesmo cidades. Vias expressas se tornaram antes de tudo um elemento de segregação. Na esfera política, a via segregada separa o homem ao volante do homem a pé. Na esfera espacial, a linha contínua da pista veloz separa os espaços em suas margens, dificultando - e às vezes impossibilitando - o livre trânsito entre um lado e o outro. Em alguns casos, a cidade é segregada de uma frente d'agua doce ou salgada. Em outros, bairros - muitas vezes de classes sociais diferentes tem sua comunicação dificultada. Dessa maneira, esta dissertação trata de investigar esse processo dialético, estabelecido a partir do conflito existente entre as dinâmicas urbanas dos espaços públicos e as necessidades individuais de circulação.

O primeiro capítulo, “O Novo Pacto Social da Rua: a Segregação como Mediação do Conflito", é marcado pelo embate entre a veloz circulação de automóveis nas cidades e a apropriação histórica e social da estrutura urbana tradicional, com destaque para o contexto das cidades norte-americanas nas primeiras décadas do século XX. Consequentemente, a segregação da circulação de automóveis em alta velocidade das demais atividades urbanas é apontada como principal solução para o conflito, opondo a noção da via expressa - como infraestrutura - aos costumes e valores atrelados aos lugares da cidade tradicional, fortemente atacada por diversas vertentes urbanísticas, tanto progressistas quanto culturalistas. Dessa constatação surge um novo embate dialético, onde as noções de "rodovia" e "cidade" se opõem de duas formas distintas: enquanto algumas soluções apresentadas negam a cidade tradicional, outras - em sua antítese - a enfrentam.

O segundo capítulo, "A Rodovia Negando a Cidade", evoca projetos relevantes desenvolvidos na primeira metade do século XX - sejam eles rodoviários ou urbanísticos - que, em suas propostas, negam as características da cidade tradicional. Enquanto algumas soluções rodoviárias pretendiam estabelecer comunicações urbanas isoladas, cercadas por uma paisagem pastoral; modelos "antiurbanos" propunham novas formas de cidade que negassem as características das grandes metrópoles, seja através de densidades menores, 
da reconstrução do espírito de "comunidade" das pequenas aglomerações, ou mesmo na conformação de uma paisagem urbana pouco edificada, em simbiose com a paisagem natural ou campestre.

Já o terceiro capítulo, "A Rodovia Enfrentando a Cidade", a antítese do capítulo anterior, apresenta projetos que, no mesmo período, enfrentaram a cidade tradicional buscando viabilizar a plena circulação de automóveis individuais em seu interior. Como forma de solucionar o problema do trânsito dos centros comerciais, a rodovia - desenvolvida fora da cidade no início do século - penetraria no complexo contexto urbano. Tal incursão passou a suscitar conflitos entre as necessidades de grande escala que essas infraestruturas atendiam e a escala dos lugares por onde passavam, transformando-os - muitas vezes negativamente - em nome do progresso.

O quarto e último capítulo, "A Rodovia Vencendo a Cidade" sintetiza o processo, onde, a partir da segunda metade do século XX, ambos os modelos de rodovia e cidade, urbanos e antiurbanos, prosperam. Consolidam-se, dessa forma, ambos os modelos - de negação e enfrentamento da cidade - como realidade inexorável da nova condição urbana do século $X X$, imposta pela ascensão do capitalismo monopolista em escala global. Ao mesmo tempo que subúrbios - e também periferias - começaram a crescer rapidamente, afastados dos centros urbanos, ao longo das rodovias; a cidade passava a ser atravessada por vias expressas urbanas que cortavam bairros consolidados e antigos centros urbanos em decadência, enfrentando - em vão - o problema do congestionamento urbano. Como afirma Marshall Berman, "por obra de uma dialética fatídica, como a cidade e a rodovia não se coadunam, a cidade deve sair" ${ }^{37}$.

Por fim, a construção dialética materialmente retratada pelos projetos e processos mencionados é analisada de forma abstrata, enfrentando-se a ideia de "progresso" como um mito contemporâneo; além de se investigar os conceitos lefebvrianos de "cidade" e "urbano", bem como as noções de "lugar" e "não-lugar", à luz da condição imposta pela modernidade do capitalismo pós-industrial. 




\section{I//// 1. \\ O NOVO PACTO SOCIAL DA RUA: A SEGREGAÇÃO COMO MEDIAÇÃO DO CONFLITO}
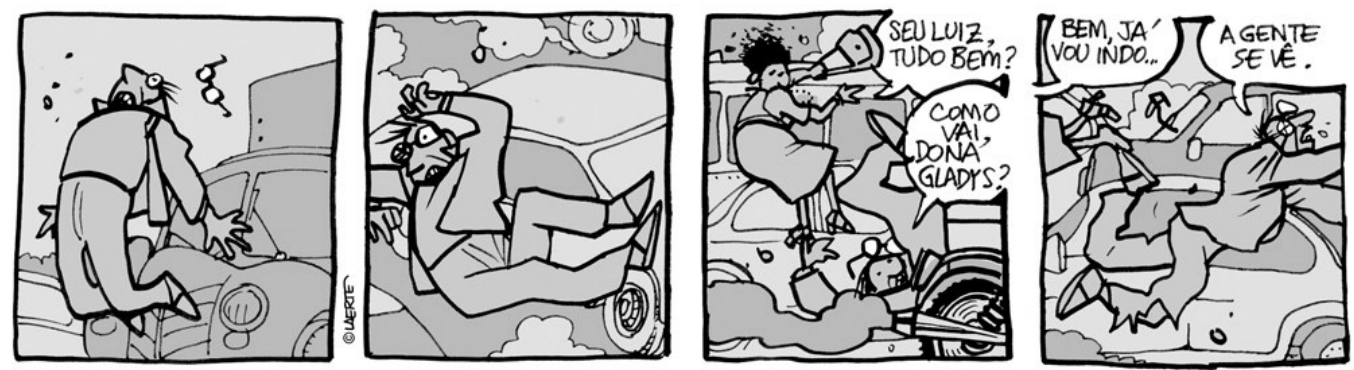

Laerte. Folha de S. Paulo, 15 de março de 2012 



\section{1. O HOMEM ATRAVESSANDO A RUA}

Antes mesmo da invenção do automóvel individual, as transformações ocorridas na cidade industrial revolucionaram as formas de utilização de seus espaços públicos. O desenho largo e retilíneo do bulevar, cartesiano, determinado pela essência do rápido deslocamento urbano, buscava maximizar a eficiência da cidade como mecanismo produtivo, de acordo com as necessidades do capital. O bulevar parisiense é um caso emblemático da nova relação que se estabelecia entre vida pública e circulação no espaço urbano. As antigas praças pré-revolucionárias da capital francesa perdem sua função de local de socialização, de parada, ou mesmo de "expressão estética do poder", transformando-se em lugares de circulação. Sua nova função se limita a fazer fluir o tráfego de veículos a cavalo no cruzamento entre duas, três, ou mais grandes vias ${ }^{1}$. Na Paris haussmanniana, os bulevares se tornam o espaço público por excelência; o lugar do comércio, da moda, onde as elites saíam para passear, para fazer o trotoir, desfrutando os prazeres de uma vida social conhecida pelos seus cafés, restaurantes e cabarés ${ }^{2}$, influenciando, desde 1860, gerações de pintores, escritores, fotógrafos ${ }^{3}$, dentre tantos outros. A vida social então deixa os espaços de repouso e passa a conviver com os espaços de circulação, emblemática da nova relação que o capital estabeleceu entre o homem moderno e o tempo.

Edmond About, em seu Paris Guide de 1867 dizia:

“(...) porque as grandes cidades, no estado atual da civilização não são mais do que aglomerações de homens apressados; que lá vão para produzir, para trocar, para desfrutar, para aparecer, são perseguidos pelo tempo, não suportam nem demora, nem obstáculo (...). Uma rua reta, larga e bem rolante aproxima e coloca por assim dizer em contato dois pontos que nos parecem distantes de uma légua. Um e outro se estabelecem às margens de grandes caminhos parisienses; os produtores e os comerciantes tiram partido para se estabelecer na corrente da circulação; o ocioso de nosso tempo tem o hábito e a necessidade de ir sem pena ou retardo onde o prazer chama..." ${ }^{4}$

No desenho dos novos espaços públicos de Paris prevalece a lógica cartesiana representada pela objetividade da linha reta. A estética do eixo é muito pertinente aos objetivos burgueses de aumento da eficiência do espaço urbano. A pavimentação das vias em ma-

1 "Ces places n'ont plus pour vocation d'être des lieux de socialisation (espace de contact médiéval) ou des lieux de parade et d'expression esthétique du pouvoir (espace de spetacle classique), mais de faciliter le trafic (espace de circulation): leur efficacité est mesurée par le nombre de voies qui y aboutissent." CHOAY, 2000: p.13.

2 SAKAGUCHI, 1998: p. 157.

3 BERMAN, 1980: p.147.

4 SAKAGUCHI, 1998: p.165. 
cadame, desejo imposto pelo imperador francês, utilizado largamente na pavimentação de estradas, era tão adequado ao tráfego de animais quanto inadequada para pedestres: criava poeira em dias secos e se tornava um verdadeiro lamaçal em dias de chuva ou neve. Haussmann, que discordou de Napoleão III quanto ao macadame, dizia que esse tipo de superfície exigia dos parisienses "ou ter uma carruagem, ou caminhar sobre pernas de $\mathrm{pau}^{\prime \prime}$.

Com isso, a vida dos bulevares, 'mais radiante e excitante que toda a vida urbana do passado', era também mais arriscada e ameaçadora para as multidões de homens e

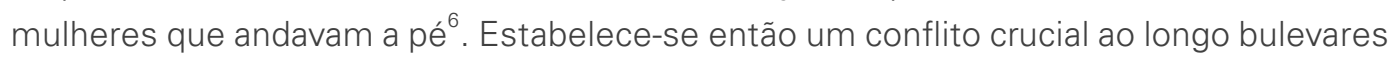
arteriais. Eles "foram desde o início sobrecarregados com uma dupla função: dar vazão aos fluxos mais intensos do tráfego através da cidade e servir de principais ruas de comércio e negócios; à medida que o volume de tráfego crescia, as duas funções se mostraram incompatíveis"7.

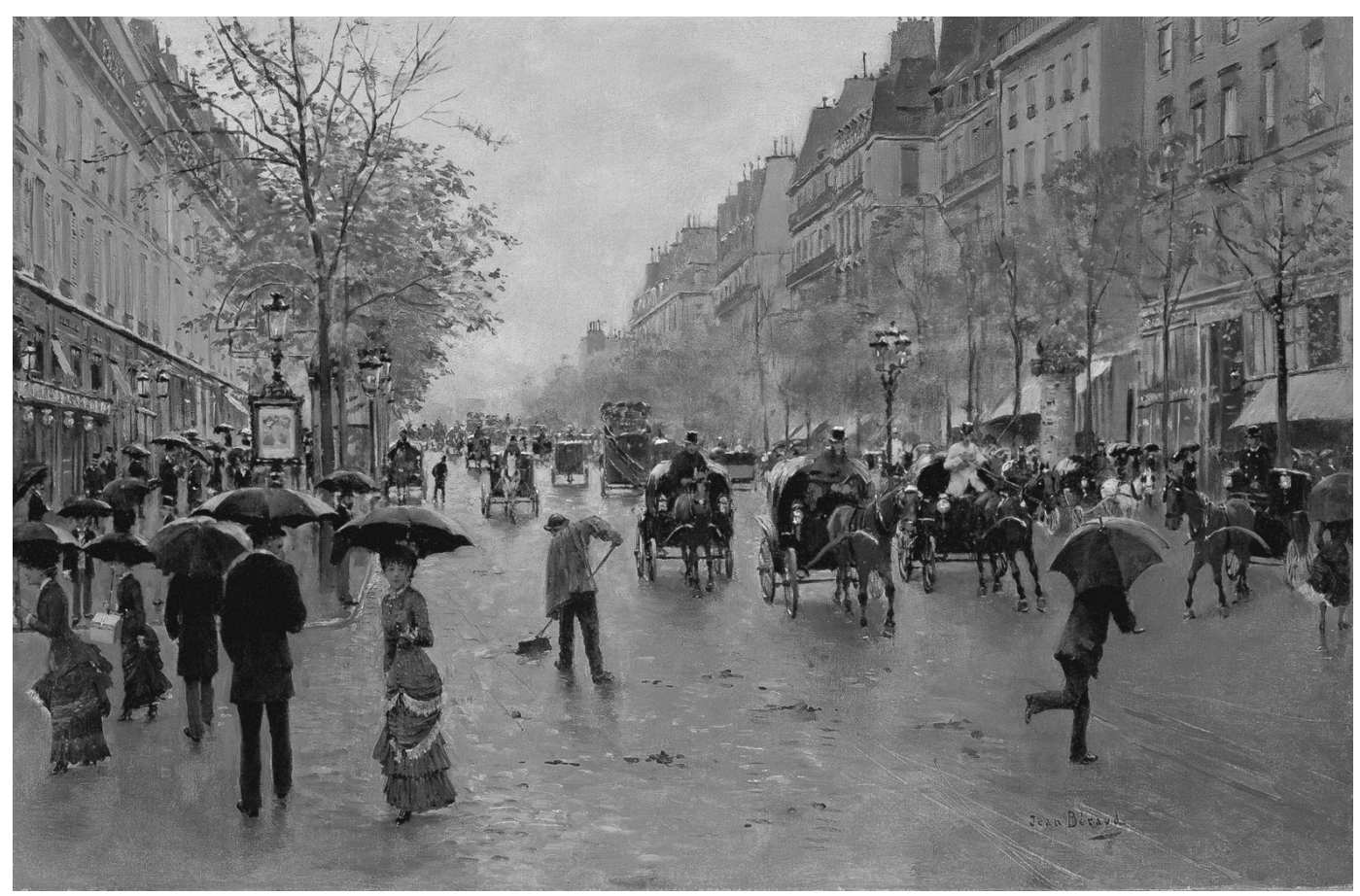

Figura 01 | Jean Béraud - "Boulevard Piossonniére en Automne," 1885

Berman destaca a percepção de modernidade na vida urbana ${ }^{8}$ após as transformações modernizadoras de Paris $^{9}$ no conjunto de poemas reunidos pelo título de "Spleen de Paris," do poeta francês Charles Baudelaire. Em seu trabalho, criado no fim de sua vida, ao longo da década de 1860, "Baudelaire nos mostra algo que nenhum escritor pôde ver com tanta clareza: como a modernização da cidade simultaneamente inspira e força a

\footnotetext{
5 BERMAN, 1986: p.153.

6 Ibid.: p. 153

7 Excerto do estudo de David Pinkney: Napoleão III e a Reconstrução de Paris. Apud. BERMAN, 1986: p.153.

8 "Seu coração e sua sensibilidade o encaminharam de maneira irresistível para as luzes brilhantes da cidade, as belas mulheres, a moda, o luxo, seu jogo de superfícies deslumbrantes e cenas grandiosas". Ibid.: p.143.

9 Como o próprio autor admite, suas leituras do Spleen de Paris são tributárias dos famosos estudos de Walter Benjamin, do início do século XX.
} 
modernização da alma de seus cidadãos ${ }^{10}$." O poeta relata esse processo de forma contundente no poema "A Perda do Halo", de 1865, de onde saiu este excerto:

'Meu amigo, você sabe como me aterrorizam os cavalos e os veículos? Bem, agora mesmo eu cruzava o bulevar, com muita pressa, chapinhando na lama, em meio ao caos, com a morte galopando na minha direção, de todos os lados, quando fiz um movimento brusco e o halo despencou de minha cabeça indo cair no lodaçal de macadame. Eu estava muito assustado para recolhê-lo. Pensei que seria menos desagradável perder minha insígnia do que ter meus ossos quebrados. (...) agora eu posso andar por aí incógnito, cometer baixezas, dedicar-me a qualquer espécie de atividade crapulosa, como um simples mortal. Assim, aqui estou, tal como você me vê, tal como você mesmo." 11

Destaca-se no poema a relação ambígua e conflituosa da vida urbana dos homens com o espaço público moderno. Ao mesmo tempo que se valoriza a vivacidade pulsante da vida metropolitana, seus espaços públicos principais - e a vida urbana que neles se desenvolve - estão em conflito com a assustadora velocidade dos veículos. É precisa a leitura do poema realizada por Berman:

"na calçada, pessoas de todas as classes se reconhecem comparando-se umas às outras segundo o modo como se sentam ou caminham. Na sarjeta, pessoas são forçadas a se esquecer do que são enquanto lutam pela sobrevivência. A nova força que os bulevares trazem à existência, a força que arranca o halo do herói $i^{12}$, conduzindo-o a um novo estado mental, é o tráfego moderno" ${ }^{13}$.

"O homem moderno arquétipo, como vemos aqui, é o pedestre lançado no turbilhão do tráfego da cidade moderna, um homem sozinho, lutando contra um aglomerado de massa e energia pesadas, velozes e mortíferas - como na imagem, o sujeito de guarda-chuva à direita. O borbulhante tráfego da rua e do bulevar não conhece fronteiras espaciais ou temporais, espelha-se na direção de qualquer espaço urbano, impõe seu ritmo ao tempo de todas as pessoas, transforma todo o ambiente moderno em 'caos'. O caos aqui não se refere apenas aos passantes - cavaleiros ou condutores, cada qual procurando abrir o caminho mais eficiente para si mesmo - mas à sua interação, à totalidade de seus movimentos em um espaço comum" ${ }^{14}$.

Com o advento do automóvel esse conflito se intensifica, a ponto de tornar as intervenções de Haussmann obsoletas. Acentuou-se o conflito entre circulação e vida pública não apenas nos bulevares e vias principais; qualquer rua ou estrada poderia ser utilizada por um motorista sedento a lançar mão das máximas velocidades que seu carro pudesse atingir.

10 BERMAN, 1986: p.143.

11 BAUDELAIRE Apud. BERMAN, 1986: p.151.

12 Tanto para Marx quanto Baudelaire, a "dessacralização" era uma das mais cruciais experiências endêmicas da vida moderna. BERMAN, 1986: p.153.

13 Ibid.: p.153.

14 Ibid.: p.154. 
Ao analisar as condições de Paris - talvez a cidade mais motorizada da Europa no primeiro pós-guerra -, Le Corbusier observa o descompasso entre as demandas de circulação e dos espaços públicos: "o automobilismo é um evento novo com consequências imensas para a grande cidade. (...) pois a forma da rua não é adaptada" ${ }^{15}$ ao carro. Como destaca Von Moss, "o crescimento da densidade urbana e da motorização fizeram da rua um teatro da perturbação, literalmente insuportável, de suas funções" ${ }^{\prime 16}$. Em seu livro L'Urbanisme, de 1924, Le Corbusier descreve um passeio por um bulevar parisiense repleto de automóveis. Ao ser expulso da rua pelo tráfego, o arquiteto relata: "foi como se o mundo tivesse enlouquecido"17, ou como ele mesmo descreve de modo mais genérico: "as cidades, onde o automóvel apareceu, tornaram-se desertos de pedras e de asfalto, no barulho e no tédio, com as condições da natureza abolidas e esquecidas" ${ }^{18}$. Corridas de automóveis no início do século XX traziam perturbação semelhante em pequenos vilarejos cortados por estradas. Os eventos ocorriam nas mesmas estradas de macadame onde antes passavam no máximo cavalos à galope e carruagens, conflitando com as demais atividades que ali ocorriam. Do ponto de vista de um motorista,

"Ovelhas e galinhas estão em toda parte que não deveriam estar, e não parece haver maneira de escapar delas. (...) Os cães são ruins demais e devem ser exterminados. São os animais mais insensatos que se pode encontrar descontrolados nas estradas. As crianças, é claro, devem ser retiradas, mas eles são escandalosamente descuidadas e muito tolas às vezes, e em suma são a maior responsabilidade dos motoristas nas pequenas cidades da Inglaterra e França" 19 .

O automóvel surge no espaço público como um intruso, um hospede indesejado, ao inviabilizar diversas atividades que antes ocorriam naturalmente. A intensificação do conflito entre espaço público e circulação em velocidade propiciada pelo motor torna premente um novo pacto acerca do uso da rua como espaço público. Roncayolo ${ }^{20}$ descreve esse processo como "primado da mobilidade": sob essa perspectiva, "deslocar" passava a ser mais importante do que "habitar". O espaço reservado à passagem, cada vez maior e mais valorizado, compete com o espaço reservado às outras atividades.

15 LE CORBUSIER Apud. SAKAGUCHI, 1998: p.185

16 Tradução livre a partir do original em francês: "L'accroissement de la densité urbaine et de la motorisation a fait de la rue un théâtre de la perturbation, littéralement insupportable, de ses fonctions». MOOS, 1971: p.147.

17 LE CORBUSIER Apud. BERMAN, 1986: p. 160.

18 LE CORBUSIER, 1979: p.18.

19 "Sheep and hens are everywhere that they ought not to be, and there seems no way of escaping them. (...) Dogs are bad enough and ought to be exterminated. They are the silliest beasts which one finds uncontrolled on the roadways. Children, of course, one defers to, but they are outrageously careless and very foolish at times, and in short are the greatest responsibility for the driver in the small towns of England and France." Apud. SCHIPPER, 2008: p. 46.

20 RONCAYOLO Apud. SAKAGUCH, 1998: p. 165. 


\subsection{O CONFLITO ENTRE O AUTOMÓVEL E A RUA NOS ESTADOS UNIDOS}

Foram os norte-americanos que tomaram a dianteira ${ }^{21}$ na problematização da questão do trânsito nas cidades, por conta da rápida disseminação do automóvel ao longo de seu território. Em um país de dimensões continentais, o automóvel foi considerado um meio de transporte estratégico e já de início tornou-se objeto de consumo dos mais difundidos por conta de seu preço acessível. Em 1902, Ransom Olds desenvolve pela primeira vez a produção de automóveis em larga escala, a preços mais baixos, batizado Oldsmobile. Poucos anos depois, em 1908, Henry Ford segue o mesmo conceito e lança o Model T: um veículo robusto, seguro, fácil de guiar e reparar. No entanto, é em 1913 que Ford revoluciona a indústria, desenvolvendo a linha de montagem de veículos que possibilitou um significativo barateamento de seus produtos através da produção em larga escala; um fenômeno de vendas que bateu a marca de 15 milhões de unidades vendidas em $1923^{22}$. Para se ter a dimensão da diferença de valores, um Model T produzido em 1908, antes da linha de montagem, custava US\$ 850. Em 1927, quando o produto foi descontinuado, o preço havia baixado para US\$290, devido ao aumento da produção. Ao final desse surto produtivo, encontravam-se em território norte-americano, na década de 1930, 85\% dos automóveis produzidos no planeta ${ }^{23}$.

Consequentemente, os norte-americanos tiveram papel fundamental na organização de políticas de tráfego e no desenvolvimento tecnológico de infraestrutura rodoviária, que posteriormente seriam exportadas mundo afora. O historiador norte-americano Peter D. Norton, em seu livro "Fighting Traffic: the dawn of the motor age in the American city", mostra em detalhes o processo de transformação do papel da rua nas cidades norte-americanas, entre as décadas de 1920 e 1930. A reflexão presente em seu trabalho - a quem deve ser creditada a estruturação das ideias apresentadas neste capítulo - possibilita não só a compreensão desse processo nos Estados Unidos, mas também lança luz ao mesmo conflito em outros contextos, já que o embate entre automóvel e espaço público hoje se tornou universal.

De acordo com Norton, até a década de 1920, diversos agentes sociais batalharam para que a rua permanecesse como um espaço livre a diversas atividades: pedestres, pais, polícia e associações comerciais batalharam para que seus direitos em relação à rua fossem mantidos. Eles questionavam a legitimidade de uma minoria de motoristas perturbar

21 Mesmo que defasados dos avanços norte-americanos, importantes avanços eram realizados também na Europa, sobretudo na Itália e na Alemanha. CABRAL, 2006: p.60. De acordo com VASCONCELLOS (1996: p.89): "A visão tradicional do planejamento de circulação está relacionada à grande influência da literatura norte-americana, que privilegia a intervenção como dedicada a 'otimização do espaço de circulação'".

22 SEIXAS, 2010: p. 69.

23 HALL, 1988: p. 54. 
a ordem social das ruas. Pedestres caminhavam livremente onde quisessem, e as crianças brincavam livremente. Nas calçadas ocorriam diversas atividades comerciais, assim como tantas outras relacionadas aos usos dos imóveis ao seu redor. Carros eram considerados "perigosos" e serviam a uma pequena minoria de motoristas. Seus veículos eram estacionados junto às calçadas, muitas vezes obstruindo a passagem e atrapalhando o comércio. Conforme aumentava a frota de veículos em uma cidade os problemas de congestionamento se tornavam cada vez mais sérios e a falta de orientação tornava o trânsito caótico. Foi necessário um grande esforço do lobby automobilístico ${ }^{24}$ para que, na década de 1930, a sociedade como um todo assimilasse o conceito de que as ruas são feitas para os carros ${ }^{25}$.

\section{SEGURANÇA NO TRÂNSITO}

Em meio a esse distúrbio da ordem social provocado pelo carro, o problema da segurança se tornou alarmante. Nos primeiros quatro anos após o fim da Primeira Guerra Mundial, mais norte-americanos foram mortos em fatalidades de trânsito do que em batalhas na França. Esse fato fora amplamente publicado na época, chocando a opinião pública de todo o país ${ }^{26}$. A grande maioria dessas vítimas eram pedestres, com significativo destaque ao elevado número de mortes infantis, causando uma atmosfera de comoção generalizada perante à opinião pública. Morte de crianças - assim como soldados - resultavam em luto coletivo, erguendo-se inclusive monumentos dedicados a elas em meio a campanhas pela segurança das ruas.

Em sua grande maioria, a responsabilidade pelas mortes ocorridas no trânsito era creditada aos motoristas, sobretudo por trafegarem em altas velocidades ${ }^{27}$, ou como afirmou, na época, um colunista de jornal, "as delinquências dos motoristas são responsáveis por quase todos os acidentes" ${ }^{28}$. Juízes ao proferir suas sentenças costumavam culpar os motoristas, onde certa vez um juiz defendeu "o direito das crianças a brincar na rua" ${ }^{29}$. Automóveis não eram considerados uma necessidade, mas sim veículos de lazer, destacando-se sobretudo pelas altas velocidades que atingia. Norton ressalta através de artigos e charges de jornal uma amostra da opinião pública negativa acerca dos automóveis. Para muitos, um automóvel não se diferenciava de uma arma de fogo, um item iminentemente perigoso, especialmente em cidades ${ }^{30}$, já para outros, tratava-se de um "ídolo pagão pedindo por sacrifícios" ${ }^{31}$.

Em meio a essa situação caótica, tornou-se latente o debate acerca da regulamentação do uso da rua. Responsável pela manutenção da ordem pública, a polícia foi a primeira responsável por estabelecer regras de trânsito nas cidades norte-americanas. Para eles, o

24 NORTON (2008) faz menção diversas vezes ao termo "motordom,", referindo-se aos diversos atores envolvidos na produção de peças, montagem e venda de automóveis.

25 Ibid.: p. 2.

26 Ibid.: p. 25.

27 Ibid.: p. 30.

28 "the delinquencies of drivers are responsible for nearly all acidentes." Ibid.: p. 30.

29 "Juries tended to favor pedestrians as well. 'Juries in accident cases involving a motorist and a pedestrian almost invariably give the pedestrian the benefi t of the doubt', a safety expert explained in 1923; 'the policy of the average juryman is to make the automobile owner pay, irrespective of responsibility for the particular accident."'

Ibid.: p. 69-70.

30 Ibid.: p. 30.

31 Ibid.: p. 23. 
automóvel era o verdadeiro elemento desagregador: era preciso adequá-lo à antiga ordem do espaço público, sendo assim fundamental privá-lo de sua característica mais fundamental: a velocidade ${ }^{32}$. Congestionamentos passam a fazer parte do vocabulário urbano por conta do aumento de veículos nas ruas e a regulamentação do trânsito estabelecida pela polícia tampouco colaborava para melhorar sua fluidez; pelo contrário, era de interesse dos oficiais de trânsito manter baixas as velocidades de circulação como forma de evitar qualquer tipo de fatalidade. As primeiras tentativas de regulamentação municipal estabelecidas pela polícia surgem na primeira década do Século XX, sendo ainda muito elementares, tornando oficiais algumas regras já consolidadas, como o tráfego do lado direito da via, a ultrapassagem pela esquerda, além de estabelecer uma velocidade segura e adequada ao tráfego urbano ${ }^{33}$. No entanto, as velocidades estabelecidas eram sempre baixas, abaixo dos vinte quilômetros por hora, e poderiam ser ainda menores ${ }^{34}$. Com o aumento da frota de veículos e uma ordenação das ruas que atrapalhava a fluidez, o problema do trânsito se tornava cada vez mais grave.
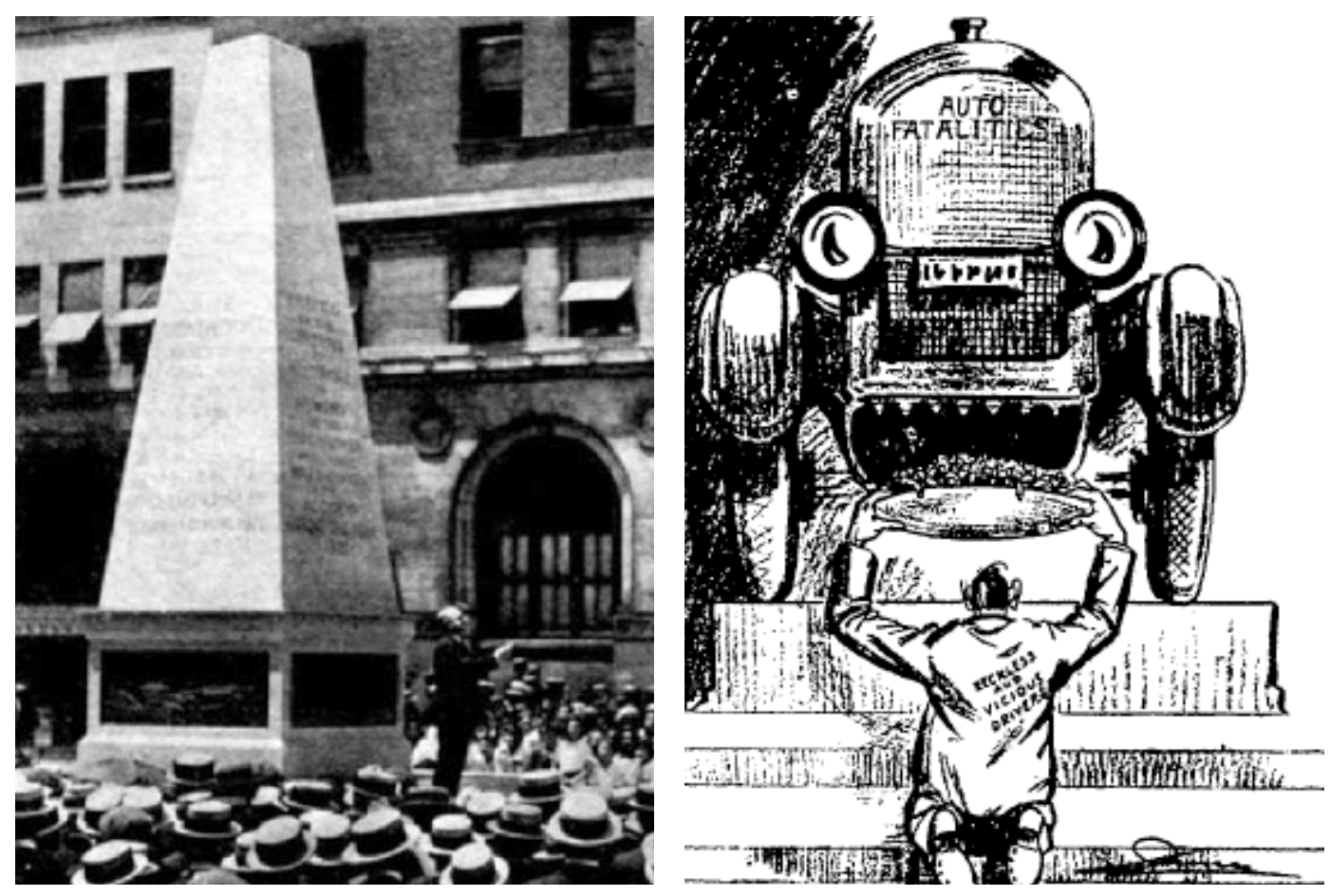

Figura 02 | Memorial dedicado às crianças vítimas de acidente de trânsito, em Baltimore, 1922

Figura 03 | "Sacrifice to the Modern Moloch." Charge publicada no St. Louis Star, em 1926

Nos cruzamentos ocorriam grande parte das fatalidades. Policiais eram alocados nos pontos principais organizando a passagem de veículos. Em 1903, a prefeitura de Nova Iorque instalou postes no centro de grandes cruzamentos como forma de organizar as conversões à esquerda. O motorista era instruído a contornar o poste, de modo a não obstruir a passagem do fluxo no sentido oposto. A medida surtiu efeitos positivos, pois tornava dispensável a presença de um policial na organização do trânsito. Na década seguinte, a sinalização das ruas - embasada pelos modelos de sinalização ferroviária - começou a ser implementada. Na cidade de Cincinatti foi inaugurado o primeiro semáforo de trânsito 
nos modelos conhecidos de hoje, no ano de 1914. Utilizando luzes para se comunicar com os motoristas o artefato exigia operação manual de um oficial que coordenava o trânsito. O elemento, no entanto, não foi difundido de imediato, tornando-se comum nas cidades americanas apenas na década de $1920^{35}$. Já a pintura do leito carroçável se torna comum: são pintadas, na década de 1910, as primeiras faixas de pedestre nos cruzamentos, mas a maioria dos pedestres as ignoravam ${ }^{36}$. Afinal, as pessoas nunca haviam sido privadas de andar nas ruas, fazendo com que "faixas de pedestre" não fizessem muito sentido. Muitos criticavam esse tipo de iniciativa, afirmavam que os automóveis eram "tiranos, que privavam outros cidadãos de suas liberdades individuais" ou "seus direitos constitucionais" ${ }^{37}$. Não havia lei que restringisse a passagem do pedestre, pelo contrário, a opinião pública afirmava que todos os cidadãos, pedestres e motoristas, tinham os mesmos direitos de utilização das ruas.
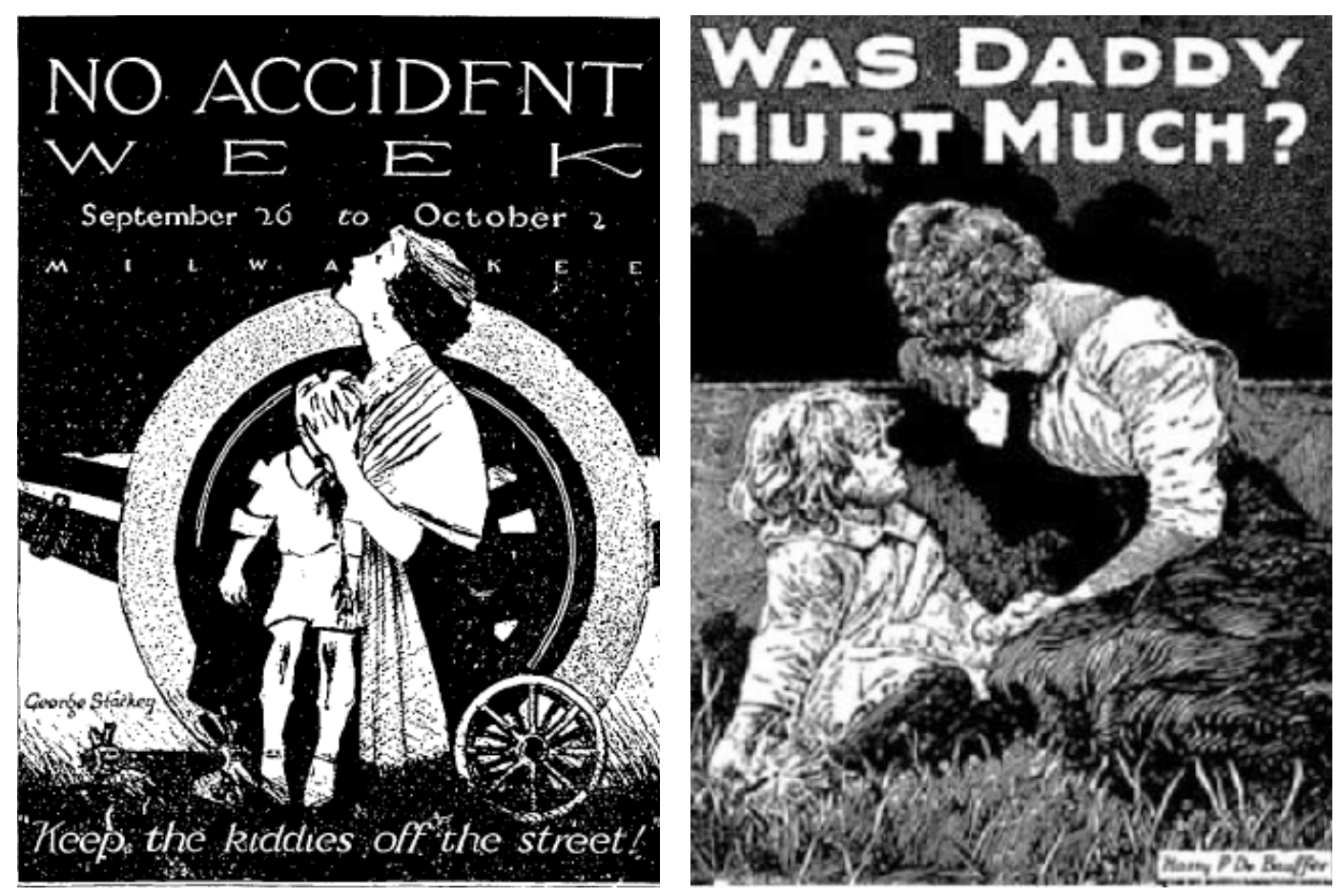

Figura 04 | Cartaz de George Starkey para a No Accident Week de 1920: "keep the kids off the street"

Figura 05 | Cartaz de Harry De Bauffer, reproduzido no Milwaukee Journal, 1920

Em contrapartida, alguns grupos sociais passam a encarar a questão da segurança no trânsito de forma diferente. Clubes do automóvel, com o apoio de igrejas, escolas e associações comerciais passaram a organizar campanhas de segurança no trânsito ${ }^{38}$. Tais campanhas, denominadas "Safety First" eram baseadas na filosofia incorporada no setor industrial, onde instruía-se o operário a tomar medidas de segurança que evitassem acidentes de trabalho ${ }^{39}$. As campanhas de segurança no trânsito baseavam-se no princípio de que mortes poderiam ser evitadas se cada cidadão fizesse sua parte. A motivação da iniciativa 
era divergente: de um lado, pais e professores queriam evitar fatalidades, preocupados com a vida de crianças; enquanto que os clubes do automóvel batalhavam para melhorar sua imagem pública.

Clubes do automóvel eram entidades organizadas por motoristas com o apoio dos fabricantes, que passaram a batalhar pelo seu direito de dirigir, sobretudo em velocidade, contrários a qualquer tipo de regulamentação do trânsito e cerceamento de suas liberdades. Eles acusavam policiais de perseguirem os motoristas e de aplicarem multas com interesse meramente financeiro ${ }^{40}$. Em meio a uma guerra na opinião pública acerca da imagem do automóvel, era preciso dar respostas à altura. No início da década de 1920, campanhas de segurança no trânsito passam a divulgar o termo "jaywalker," referindo-se aos pedestres que não atravessavam nas faixas de pedestre. O termo tinha uma conotação pejorativa, partindo do termo "Jay", que poderia ser traduzido do inglês como "caipira". Um jaywalker seria, portanto, um forasteiro que não sabe como se comportar diante as regras da cidade e atravessa a rua fora da faixa de pedestres ${ }^{41}$. De início, o termo era considerado ofensivo, porém, ao longo da década de 1920, passou a ser incorporado no vocabulário norte-americano. Segundo Norton, na década de 1930 o termo já havia sido assimilado, demonstrando a difusão na opinião pública do conceito de que o espaço da rua está destinado primordialmente ao carro. Mais do que isso, trata-se de um contundente exemplo do intenso trabalho realizado pelo lobby automobilístico - organizado por diversos agentes sociais relacionados ao automóvel, desde fabricantes e vendedores, até simples entusiastas - para transformar a opinião pública norte-americana acerca do papel da rua nas cidades.

Mortes e acidentes no trânsito traziam uma péssima reputação para o lobby automobilístico, que temia que o crescimento da imagem negativa do automóvel perante à opinião pública pudesse impor restrições ao seu uso. Tais restrições privariam motoristas da liberdade que o automóvel propiciava, e, sobretudo, prejudicariam o futuro das vendas de veículos. De acordo com Norton, o lobby automobilístico passa a se unir de forma organizada a partir de um plebiscito ocorrido em Cincinatti, em 1923, onde foi votada a obrigatoriedade de limitadores mecânicos de velocidade nos motores dos automóveis. A ideia - que ganhava muitos adeptos frente ao grande número de mortes - ameaçaria um dos conceitos fundamentais do automóvel, privando-o de uma de suas principais características. Foi a partir dessa ameaça - e do sucesso em seu combate - que o lobby automobilístico criou diversas e bem financiadas instituições de segurança que redefiniram o problema nos Estados Unidos ${ }^{42}$; passou a ser de interesse da indústria automobilística combater os acidentes de trânsito.

O lobby automobilístico atacou a questão da segurança na opinião pública partindo da assimilação de uma visão modernizadora, onde "nascia uma nova era", para qual era preciso construir um novo conceito de segurança no trânsito, adequando a cidade à "era do motor" ${ }^{43}$. Através desse discurso, constituía-se uma nova ideologia acerca do papel público da rua, que passaria a ser um espaço primordialmente de circulação em velocidade. O automóvel

40 "To the clubs, the police were at best biased against motorists, and clubs accused police of harassing motorists simply to raise money from fines. 'Some of our cities live off the motorist', one auto club executive complained. 'The fine is what they are interested in'" NORTON, 2008: p. 78.

41 Ibid.: p. 72. Hoje, o verbo "to jaywalk" - em inglês - está dicionarizado, designando o ato de caminhar desobedecendo as regras de trânsito.

42 lbid.: p. 97.

43 Ibid.: p. 208 
deixaria de ser um simples "carro de lazer" para se transformar em uma necessidade do mundo moderno, elemento fundamental que mereceria seu espaço na rua, da mesma forma que os pedestres. Para divulgar essa ideologia, a NACC - National Automobile Chamber of Commerce - incorporou em sua papelaria oficial, ao final de cada carta, uma frase de seu presidente, que dizia: “O Carro a Motor se Tornou um Indispensável Instrumento na Nossa Vida Política, Social e Industrial (...) o carro se tornou um item essencial, e não mais um luxo" ${ }^{44}$.

Desde então, a responsabilidade pelos acidentes de trânsito deixaria de ser de exclusividade do motorista, e passaria a ser compartilhada com o pedestre. Norton cita algumas frases representativas desse discurso enviesado. Em 1924, George Graham, fabricante de automóveis e presidente do comitê de segurança da NACC, afirma que "pedestres precisam ser educados para saber que automóveis tem direitos" "45. John Hertz, presidente da Yellow Cab Company, afirma que "Estamos vivendo em uma era do motor, e precisamos não apenas de uma educação (...), mas um senso de responsabilidade da era do motor" ${ }^{46}$.
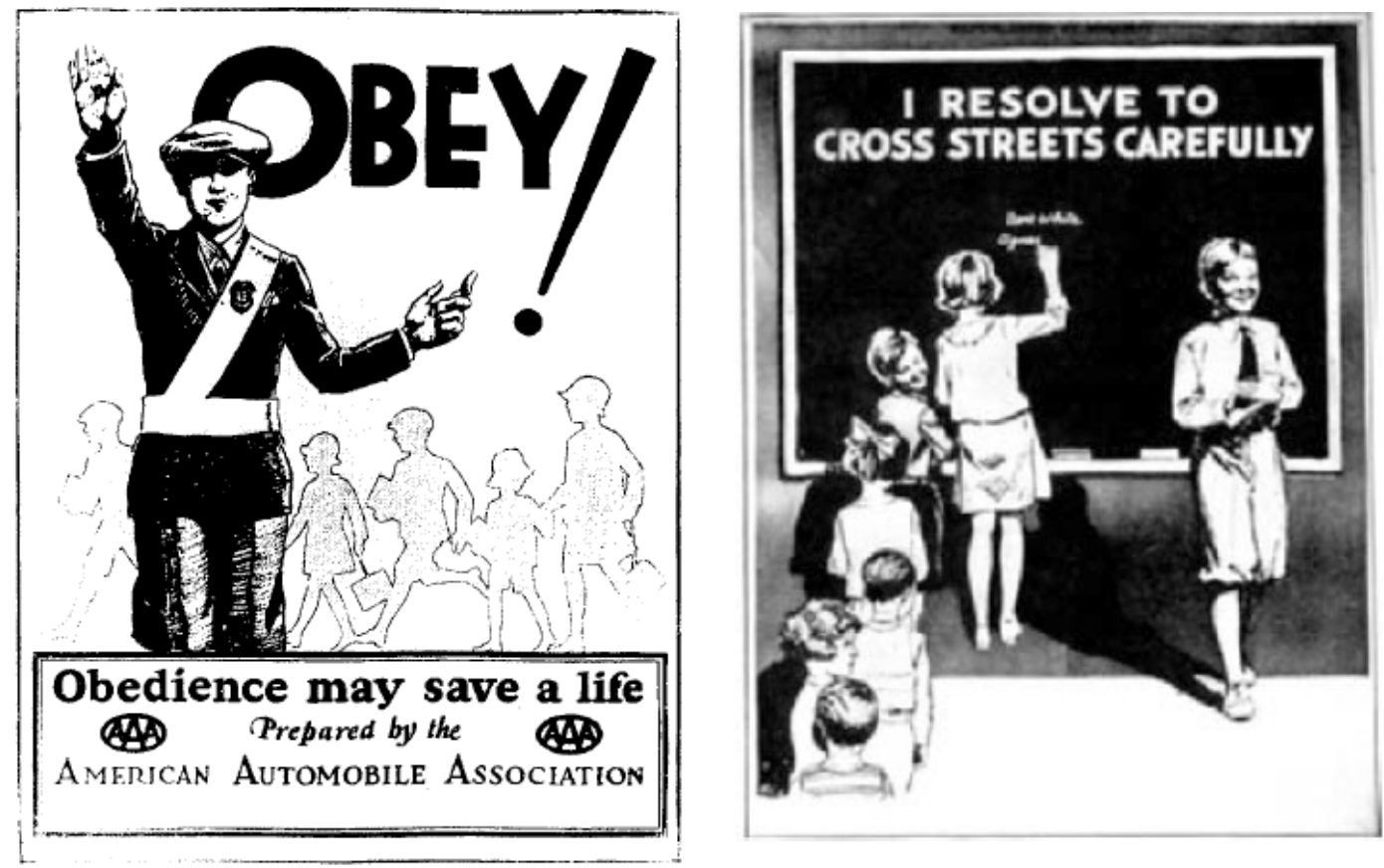

Figura 06 | Cartaz da American Automobile Association, 1927

Figura 07 | Cartaz de campanha de segurança do Chicago Motor Club, 1932.

Norton consegue retratar através dessa e de muitas outras declarações a forma como a imprensa transformou sua maneira de reportar fatalidades de trânsito. O mesmo Graham, por exemplo, nota na mídia uma postura desfavorável aos motoristas ao chamar qualquer morte no trânsito de 'morte do automóvel', fosse o motorista responsável ou não. Para ele, "era hora de mudar essa prática" ${ }^{47}$, sendo necessário influir na maneira

\footnotetext{
44 "The Motor Car Has Become an Indispensable Instrument in our Political, Social and Industrial Life" (...) "The automobile, has become an essential rather than a luxury." NORTON, 2008.: p. 220.

45 "Pedestrians must be educated to know that automobiles have rights." Ibid.: p. 207.

46 "We are living in a motor age, and we must have not only motor age education, but a motor age sense of responsibility." Ibid.: p. 207.

47 "was time to challenge such practices." Ibid: p. 208-9.
} 
como essas mortes eram retratadas na imprensa. Como estratégia para difundir essa visão em todo o país, ao invés de comprar espaços em centenas de jornais, a NACC criou sua própria agência de notícias sobre acidentes, garantindo que os repórteres recebessem os fatos essenciais. Além de dar sua visão acerca do caso, cada notícia era acompanhada de sugestões para que acidentes desse tipo não voltassem a acontecer. Ao interpretar as palavras do próprio Graham sobre o trabalho da agência, fica evidente a postura tendenciosa enviada para os jornais: "na maioria dos acidentes de automóvel a culpa está com o pedestre, e não com o motorista" ${ }^{48}$. Posteriormente, um magistrado da Corte de Trânsito de Nova lorque, nota que "virou moda creditar setenta a noventa por cento de todos os acidentes como jaywalking" ${ }^{49}$. Ele inclusive relata suas suspeitas acerca do lobby automobilístico sobre a responsabilidade em relação a essa súbita mudança na divulgação dessas notícias.

Mesmo creditando a maioria das mortes e ferimentos no trânsito à irresponsabilidade dos pedestres, havia ainda uma porção significativa das fatalidades causadas por motoristas, que inevitavelmente seriam responsabilizados. Era preciso justifica-las de forma a não relacionar as mortes com as altas velocidades praticadas pelos veículos, ou qualquer outro motivo que pudesse levar a redução dos limites de velocidade. Como fizera com o pedestre, mais uma vez, a saída encontrada pelo lobby automobilístico foi culpar o indivíduo, apontando a "irresponsabilidade" e a "falta de cuidado" de certos motoristas como a causa de acidentes. Segundo essa lógica, se esses motoristas fossem impedidos de dirigir, os números de acidente cairiam ${ }^{50}$. Além de perseguir alguns de seus pares e clientes, o lobby automobilístico demonstraria seu comprometimento com a questão da segurança ao defender punições a esses motoristas. Como resultado dessa política, defendeu-se a implementação em escala nacional de licenças para motoristas através do estabelecimento do código de trânsito nacional em 1926, que exigia a emissão de licenças para dirigir após a aprovação em um exame ${ }^{51}$.

\section{CONGESTIONAMENTOS E ENGENHEIROS DE TRÁFEGO}

Como consequência do rápido crescimento da frota de automóveis nos Estados Unidos, os centros das cidades norte-americanas passaram a ter que conviver com congestionamentos cada vez maiores e frequentes com o passar dos anos. As medidas tomadas por policiais para organizar o tráfego nas ruas na primeira década do século primavam pelo estabelecimento da ordem sem se preocupar com a fluidez do tráfego. Afinal, as baixas velocidades no trânsito diminuíam o número de acidentes ${ }^{52}$. Para o comércio, a dificuldade em circular e estacionar pelo centro da cidade prejudicava as vendas e precisava ser combatida. Ao mesmo tempo, era fundamental manter o centro com a maior densidade possível, aproximando cada vez mais clientes; era preciso tornar a densidade eficiente.

"In a majority of automobile acidentes the fault is with the pedestrian rather than with the automobile driver." NORTON, 2008: p. 210.

49 "It is now the fashion to ascribe from 70 to 90 per cent of all accidents to jaywalking,." lbid.: p.210.

50 Ibid.: p.214-5.

51 Ibid.: p. 218.

52 Ibid.: p. 106. 
Como alternativa às soluções de trânsito apontadas pela polícia, associações comerciais voltaram-se para os engenheiros em busca de especialistas que apontassem soluções de aumento da fluidez das áreas congestionadas da cidade ${ }^{53}$. A engenharia já havia aumentado a eficiência de diversos serviços públicos, como abastecimento de água e saneamento básico e pareciam os mais indicados para organizar os fluxos de veículos nas cidades. Norton também afirma que engenheiros não eram apenas apontados para resolver problemas de ordem técnica, mas também questões sociais complexas, resolvendo-as de forma técnica ${ }^{54}$. Engenheiros já faziam parte da administração municipal em quase metade das cidades americanas em $1919^{55}$. Era preciso encontrar formas baratas e eficientes que resultassem em alívio dos congestionamentos imediatamente. A solução apontada passou pelo controle de tráfego ${ }^{56}$. Através de análises sistemáticas e de pesquisas ${ }^{57}$ que auxiliavam no entendimento do problema do trânsito, engenheiros de tráfego - uma profissão que surgia naquele momento - buscavam regulamentar o espaço viário, estabelecendo maior fluidez e velocidade.

Norton afirma que os primeiros engenheiros de tráfego acreditavam que um espaço viário eficiente poderia beneficiar todos os agentes envolvidos ao aliviar as ineficiências através da regulamentação do uso do espaço. Para que lhes fosse concedida permissão para estabelecer restrições para as ruas e calçadas, engenheiros lançaram mão do princípio do "interesse público", utilizado especialmente para a implementação de serviços de infraestrutura - como água, gás, luz e transporte coletivo - que lhes permitia estabelecer regras também sobre o funcionamento do trânsito ${ }^{58}$. Aliando-se ao controle do zoneamento das áreas centrais, a regulamentação era vista como forma de tornar a cidade como um todo mais eficiente. Ao contrário da metodologia policial, baseada na opressão de condutas consideradas indevidas, engenheiros de tráfego apostavam no que Norton chama de "regulamentação positiva". Este princípio estabelecia regras de conduta que deviam ser obedecidas em nome do beneficiamento coletivo, que impera sobre o interesse individual ${ }^{59}$.

A definição de "utilidade pública", antes empregada apenas para infraestruturas com utilidade única, como trilhos, fios e canos, estava sendo ampliada para incorporar a rua como um todo. Afinal, a capacidade de transporte que a rua suportava se aproximava de sua saturação, e "o limite de espaço disponível nas ruas urbanas justificavam a regulamentação de seus usos" ${ }^{\prime 60}$, tornando-as passíveis de taxação. Economistas enquadravam as ruas na categoria de monopólios por exigirem grandes investimentos, pela sua capacidade reduzida, por não serem facilmente duplicáveis e por fornecerem serviços de deslocamento inseparáveis de sua infraestrutura ${ }^{61}$. Para que a rua fosse o mais eficiente possível para a maior quantidade de pessoas, engenheiros de tráfego também aplicavam o conceito de equidade em suas regulamentações, proibindo certas atividades realizadas por poucos que prejudicassem o bem-estar geral ${ }^{62}$. 
Ao contrário da política de trânsito policial, que opunha velocidade e segurança em nome da ordem, os engenheiros defendiam a velocidade, afirmando que seria possível conciliá-la com medidas de segurança. Afinal, o aumento da velocidade de circulação de veículos na cidade aumentaria a capacidade da via, tornando-a mais eficiente. Em contrapartida, ao incorporar uma visão utilitarista da rua como área de "utilidade pública" as políticas municipais passavam a trata-la como espaço primordialmente destinado à circulação, fazendo com que, naturalmente, qualquer outra atividade relacionada ao seu uso fosse desestimulada. Foram os engenheiros de tráfego que regulamentaram o uso da calçada como espaço exclusivo de circulação do pedestre, recomendando a retirada de qualquer tipo de obstáculo - como quiosques, caixas e até fossos de iluminação - que obstruísse a passagem de pessoas. Dessa forma, pedestres eram estimulados a não caminhar ao longo do leito carroçável, local única e exclusivamente para a passagem de veículos ${ }^{63}$.

Engenheiros de tráfego fizeram largo uso de sinalização como forma de controle sobre o trânsito, implementando ruas de mão única e demarcando faixas de circulação em vias largas. Um de seus maiores sucessos foi o uso de semáforos coordenados, que permitiam que veículos trafegassem por diversos blocos sem interrupção, aumentando a velocidade de circulação. O primeiro sistema integrado de semáforos foi implementado na área do "Loop" de Chicago, onde quarenta e nove cruzamentos foram conectados a uma única central que sincronizava seu funcionamento. Os benefícios causados pelo sistema foram notáveis, melhorando significativamente a velocidade de tráfego dos veículos, tornando-o uma unanimidade entre motoristas ${ }^{64}$. No entanto, ao tornar os semáforos extremamente eficientes para os carros, a travessia de pedestres havia se tornado quase impossível, pois não haviam sido levados em consideração dentro da sua concepção. Como afirmou um engenheiro administrador municipal de Cincnatti, "conforme as demandas de tráfego se tornam mais severas o uso das ruas para outros propósitos deve ser mais e mais restrito" ${ }^{65}$.

Ao longo dos anos, engenheiros de tráfego passaram a entender cada vez melhor o problema do trânsito nos centros urbanos e passaram a identificar o próprio automóvel como um dos seus principais atores. Como defensores da eficiência dos densos centros urbanos, eles não podiam perdoar os automóveis por ocuparem tanto espaço ${ }^{66}$. Rapidamente engenheiros de tráfego notaram que o estacionamento de veículos ao longo das calçadas era responsável pela obstrução do trânsito. Essa análise resultou em propostas de proibição de estacionamento nas vias principais. Alguns engenheiros chegaram a pensar na possibilidade de restringir a passagem de veículos em ruas importantes, que, em casos extremos, poderia levar até a proibição do tráfego de veículos nas ruas centrais durante o horário comercial ${ }^{67}$.

Mesmo assim, a atuação restritiva dos engenheiros de tráfego tinha eficácia limitada. 0 desenho tradicional das ruas dos centros urbanos não mais conseguia suportar a crescente quantidade de veículos em circulação. Para engenheiros de tráfego, os carros ocupavam uma quantidade desproporcional de espaço em relação a sua eficiência como meio de transpor-

63 NORTON, 2008: p. 134.

64 Ibid.: p. 135.

65 "as traffic demands grow more acute the use of streets for other purposes must be more and more restricted." Ibid.: p. 151.

66 Ibid.: p. 151-2.

67 Ibid.: p. 155. 


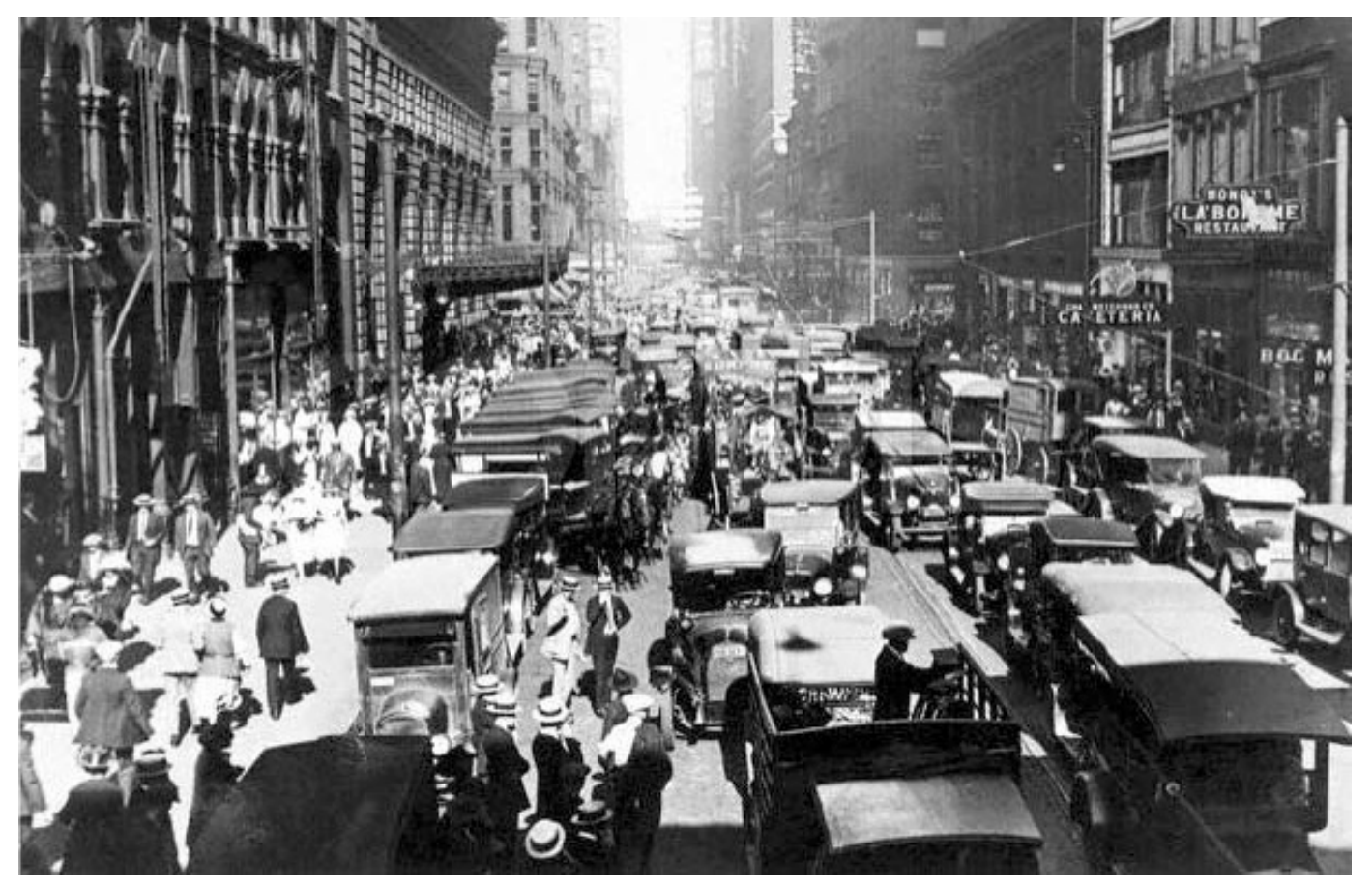

Figura 9 | Chicago em 1929, antes da coordenação semafórica e proibição de estacionamento

$t e^{68}$. Em contrapartida, os sistemas de bonde eram muito mais eficientes ao transportar em um único veículo uma quantidade muito maior de pessoas. Estabelecia-se uma batalha pela superfície das saturadas ruas das cidades, respaldada por um embate de ordem econômica: enquanto os bondes representavam o conceito de utilidade pública através de monopólio regulamentado pelo estado, o automóvel representava o livre mercado, mais alinhado com os padrões ideológicos norte-americanos ${ }^{69}$.

\section{LOBBY AUTOMOBILÍSTICO: POR MAIS ESPAÇO VIÁRIO}

Com o aumento de medidas que restringiam direitos individuais, as políticas de regulamentação defendidas pelos engenheiros de tráfego passaram a perder não apenas o apoio da opinião pública, como também passaram a ser considerados uma ameaça pelo lobby automobilístico. O receio do lobby era que a visão do automóvel como inimigo da eficiência e o aumento de medidas proibitivas que limitassem seu potencial de circulação em liberdade, diminuíssem o interesse da população na compra de veículos. Roy Chaplin, da Hudson Motor Car Company, chegou a afirmar que a "regulamentação não era apenas uma política ruim, mas também contrária aos princípios norte-americanos"70 ${ }^{170}$ A preocupação do lobby

68 NORTON, 2008: p. 139.

69 O lobby automobilístico, foi capaz de vencer essa batalha livrando-se da concorrência através de uma ação coordenada de compra e sucateamento de empresas de bonde em mais de quarenta e cinco cidades norte-americanas entre 1936 e 1950, num processo que posteriormente se tornou conhecido como o "Great American Streetcar Scandal" (HEREÑú, 2016: p.64). Após o sucateamento das empresas e a queda da qualidade do serviço oferecido, suas atividades foram encerradas, tornando o leito carroçável espaço exclusivo para os veículos sobre rodas.

70 "Regulation was more than just bad policy it was contrary to American principles." Apud. NORTON, 2008: p. 205. 


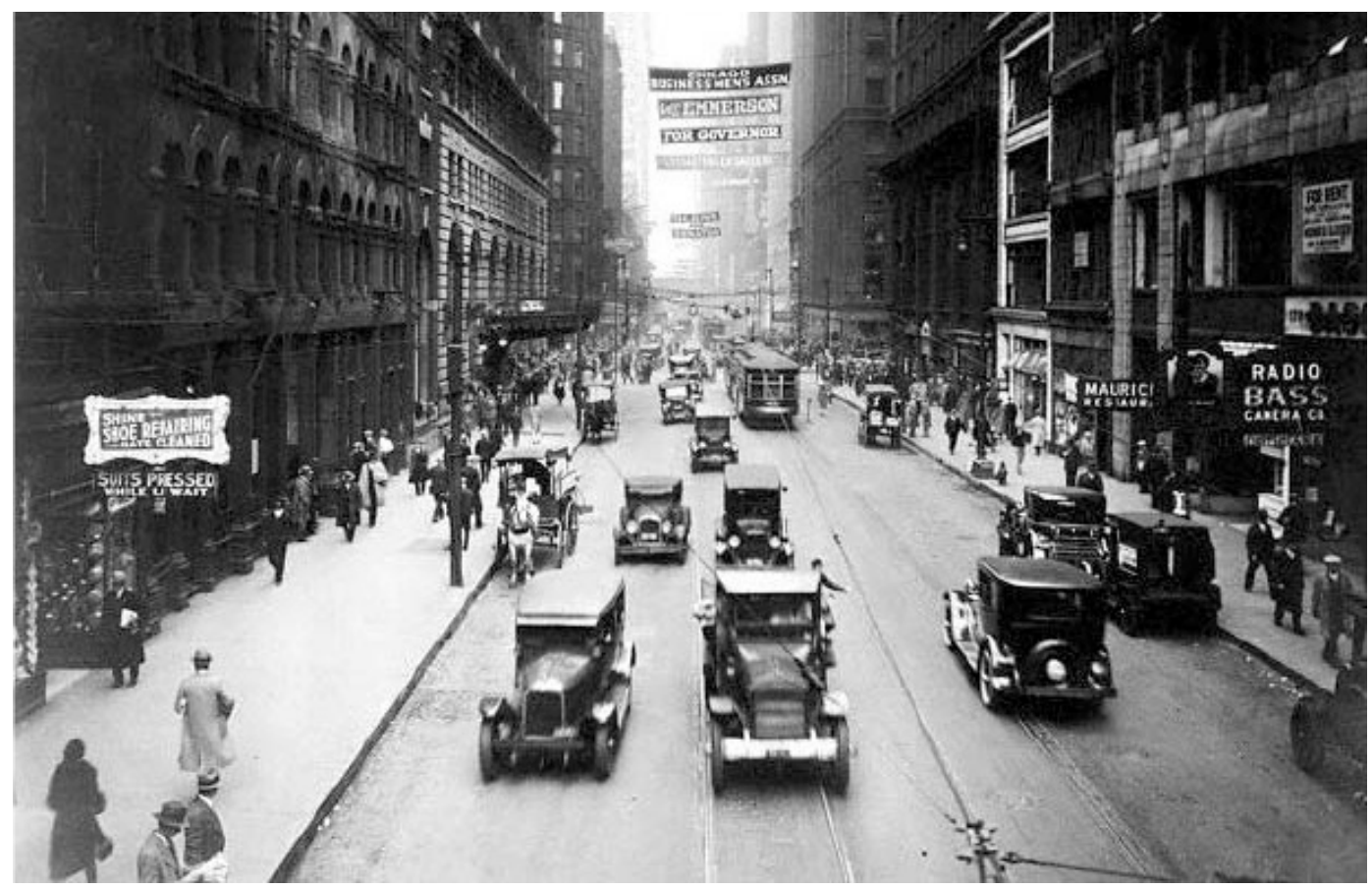

Figura 10 | Chicago em 1929, depois da coordenação semafórica e proibição de estacionamento

automobilístico tinha fundamentos muito concretos. A saturação da infraestrutura viária chegou ao ponto de afetar negativamente a venda de automóveis, sobretudo nas cidades ${ }^{71}$.

Entre os anos de 1923 e 1924 o ritmo de venda de automóveis caiu significativamente, devido - de acordo com a NACC - aos congestionamentos e as polêmicas envolvendo a questão da segurança" ${ }^{72}$. O lobby automobilístico buscava diversas formas de ampliação das vendas, desde o barateamento de preços, o lançando alterações anuais nos modelos, incentivos a compra de dois veículos por família e ao mesmo tempo buscavam conter a prática da venda de carros usados. As montadoras buscavam também expandir as vendas fora do país, em locais onde as ruas ainda não estivessem saturadas ${ }^{73}$. Mesmo assim, era preciso resolver o que se entendia como a raiz do problema. Insatisfeitos com a atuação dos engenheiros de tráfego e suas posturas proibitivas, o lobby automobilístico passou a procurar novas formas de combater o problema do trânsito que permitissem uma maior presença de veículos nas ruas. Para eles, a origem do problema era clara, sendo resultado da inadequação da infraestrutura de tráfego da cidade tradicional. Era preciso transformar a rua, aumentando sua capacidade além da demanda, através de transformações radicais do espaço urbano ${ }^{74}$. Afinal, com o aumento do espaço destinado à circulação de veículos, maiores seriam suas vendas, mesmo que sua capacidade voltasse a chegar a um novo limite no futuro. Do ponto de vista comercial, o plano funcionava muito bem.

A cruzada do lobby automobilístico contra a regulamentação do trânsito imposta pelos engenheiros de tráfego tinha como base os conceitos clássicos de liberalismo político e 
econômico ${ }^{75}$ - também associados à imagem do próprio automóvel. Enquanto engenheiros pregavam um discurso tecnocrático, os empresários se opunham através de um discurso de valorização da livre iniciativa, adaptado para os problemas sociais da época ${ }^{76}$. O automóvel incorporava, como nenhum outro bem de consumo, o conceito de "liberdade", que se opunha ao conceito de "regulamentação." "Este país foi fundado no princípio de liberdade (...). Agora o automóvel trouxe algo que é parte integral do espírito americano - a liberdade de movimento"77, afirmou o pesquisador Miller McClintock, diretor do Erskine Bureau for Street Traffic Research da Universidade de Harvard. Para ele, a rua não deveria ser regulamentada, pois "o congestionamento do trânsito nas ruas é um problema de desequilíbrio entre oferta e demanda" 78 .

Miller McClintock foi o primeiro engenheiro de tráfego a adquirir um doutorado em sua área de atuação, em 1924, abordando pela primeira vez de forma acadêmica os princípios de regulamentação de tráfego. No ano seguinte, com o patrocínio da montadora Studebaker - presidida por Albert Russel Erskine -, McClintock fundou seu instituto, onde realizava pesquisas para a melhora das condições de trânsito das cidades. De acordo com Norton, a abordagem e os resultados das pesquisas do Erskine Bureau sempre estiveram alinhados com os interesses do lobby automobilístico, que financiava suas ações ${ }^{79}$. Antes defensor dos princípios de controle de tráfego como solução para o trânsito urbano - como colocado em seu doutorado -, McClintock paulatinamente passou a apoiar o aumento do espaço viário como saída: "a solução mais básica para o congestionamento de ruas e estradas está na provisão de mais área de rua" ${ }^{80}$. Com a chancela de uma renomada universidade através do Erskine Bureau, McClintock se tornou um dos principais porta-vozes dos interesses do lobby automobilístico dentro da academia ${ }^{81}$. A NACC também instaurou seu próprio “departamento de Segurança e Trânsito" no final de 1923, utilizado para debater e divulgar os conceitos do lobby automobilístico, sem sequer ensaiar qualquer tipo de imparcialidade. No entanto, ao contrário do que ocorria no Erskine Bureau, seus membros não pertenciam a esfera acadêmica; pelo contrário, eram executivos de diversos setores da indústria.

Em meio a esse embate, o secretário de comércio - e posteriormente presidente dos Estados Unidos - Herbert Hoover teve importante papel na organização dos agentes do ramo automobilístico na posterior regulamentação das regras de trânsito em âmbito nacional. A partir da repulsa ideológica ao modelo de forte regulamentação estatal defendido pelos engenheiros de tráfego, Hoover era favorável a associação entre diversos representantes do setor produtivo - aqui chamado de lobby automobilístico -, visando o estabelecimento de regras comuns através de leis, normas e padrões a serem determinados a toda indústria. Segundo ele, os arranjos estabelecidos perante todos os membros de um determinado setor tornariam desnecessária a intromissão do Estado em questões de âmbito comercial.

75 NORTON, 2008: p. 166.

76 Ibid.: p. 166.

77 "This country was founded on the principle of freedom (...). Now the automobile has brought something

which is an integral part of the American spirit - freedom of movement." Ibid.: p. 168.

78 "Street traffic congestion is a problem of unbalanced supply and demand". Ibid.: p. 175.

79 Ibid.: p. 165

80 "The most basic solution for street and highway congestion lies in the provision of great street area." Ibid.:

p. 167.

81 Ibid.: p. 169. 
A esse modelo de regulamentação os historiadores deram o nome de "associacionismo" ${ }^{82}$. Dentre muitas organizações realizadas em diversas áreas do setor produtivo norte-americano, Hoover organizou o debate através da National Conference on Street and Highway Safety, em 1924, que resultou em um grupo permanente de trabalho, que durante seis anos discutiu diversas questões relacionadas ao trânsito ${ }^{83}$.

Interessante notar que dentre os representantes consultados por Hoover pouquíssimos possuíam perfil técnico, reduzindo drasticamente a participação dos engenheiros de tráfego. Eram representantes do lobby automobilístico, homens de negócios defendendo interesses mais comerciais do que técnicos. Norton destaca a postura de Hoover, que acreditava que os empresários dos setores industriais eram tão especialistas em suas áreas quanto os engenheiros do ramo dos transportes. Os empresários haviam se tornado - nas palavras de Hoover - membros de "uma nova profissão, a administração de empresas" ${ }^{84}$, numa tentativa de tornar o "administrador" um profissional tão habilitado para argumentar quanto um engenheiro. Ao trata-los como técnicos, o secretário de comércio buscava garantir credibilidade aos debates que ele promovia, sem que, no entanto, houvesse representatividade de ambas as formações.

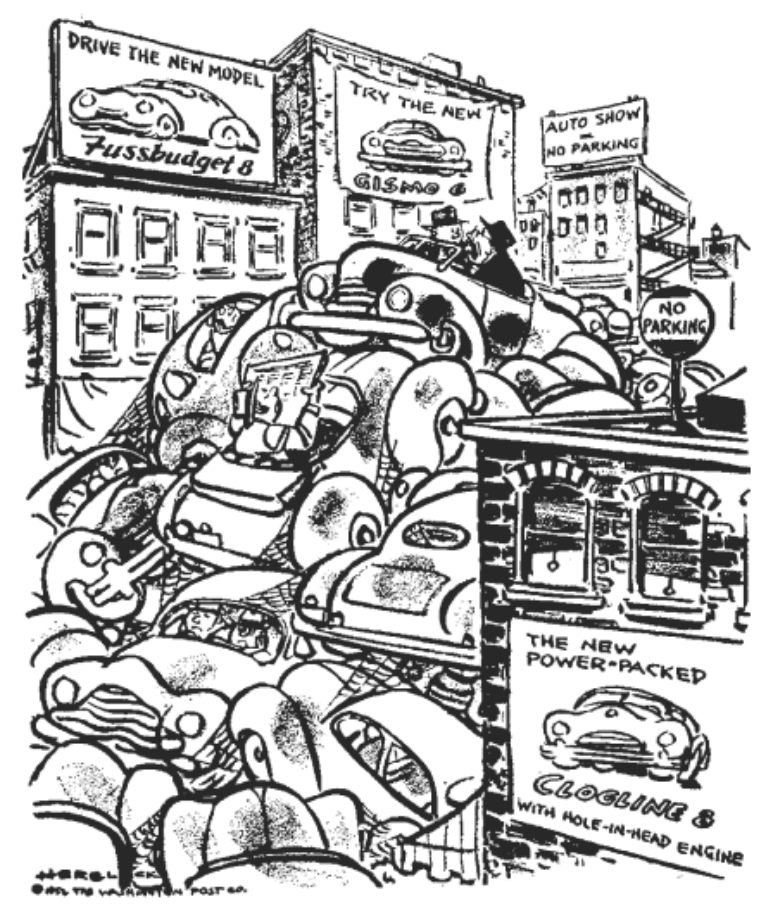

Figura 08 | Charge sobre o trânsito nas cidades norte-americanas, 1952

Como resultado, o lobby automobilístico lutou para estabelecer uma mínima presença do estado na regulamentação do trânsito, reduzindo drasticamente o número de leis relacionadas. Para tal, diversas entidades propuseram o estabelecimento de um código

82 Tradução do termo em inglês "asociationism." NORTON, 2008: p. 179.

83 Ibid.: p. 180

84 Ibid.: p. 181-2. A administração de empresas surge como ciência no início do século XX, com destaque ao trabalho do engenheiro americano Frederick Winslow Taylor, que buscava aplicar métodos científicos de trabalho para incrementar a produtividade industrial. 
veicular uniforme que fosse adotado pelos estados. Ao transferir a legislatura para a esfera estadual seria possível conter a multiplicidade de leis de trânsito propostas pelos municípios. Seria uma forma bastante eficiente de controlar o ímpeto regulatório. Ao mesmo tempo, foi estabelecido um comitê para elaborar uma portaria de trânsito municipal, que criasse diretrizes de organização do trânsito urbano em âmbito nacional baseadas nos interesses empresariais. Segundo Norton, essa portaria sedimentou o processo de transformação da rua em espaço de uso exclusivo para circulação, reestabelecendo definitivamente sua função social nos Estados Unidos. A rua deixava de ser um espaço de uso público compartilhado e se tornava legitimamente o espaço do carro.

A portaria também determinou a necessidade de transformação do espaço do viário principal, de modo a se adequar às demandas do tráfego. Dessa maneira, o trânsito não seria mais resultado do excesso de carros nas ruas, mas sim o contrário: as ruas que estariam pequenas demais para receber a crescente frota automobilística. Como colocou um dos membros do comitê, "os movimentos modernos de massa de tráfego veicular demandam o máximo da área da rua, que em seu conjunto é inadequada demais em muitos municípios" ${ }^{85}$. As primeiras propostas de aumento da superfície das ruas baseavam suas estratégias no alargamento das ruas - de forma semelhante às intervenções realizadas na Paris de Haussmann, hierarquizando o sistema viário em diferentes tipos de via ${ }^{86}$. Em outros casos, viadutos e pontes foram erguidos sobre rios, ferrovias e outros obstáculos, conectando trechos segmentados do sistema viário existente. No entanto, mesmo tais intervenções tinham poder limitado de transformação ${ }^{87}$ em relação ao crescimento da frota.

Ao longo da década de 1920, especialistas passaram a apontar para a necessidade de uma transformação nos padrões de velocidade e capacidade do sistema viário ${ }^{88}$ através de mudanças estruturantes em uma escala mais abrangente. Para isso, a portaria indicava os engenheiros de rodovias como os profissionais ideais para resolver os problemas de trânsito nas cidades ${ }^{89}$, através de sua expertise adquirida no desenvolvimento de projetos de rodovias. Como clamou McClintock, cidades precisavam "ajustar sua disposição física (...) para os requerimentos da era do automóvel" ${ }^{90}$.

"modern mass movement of vehicular traffi c demands the utmost in street area, which is altogether too inadequate in many municipalities." NORTON, 2008: p. 192.

86 DIMENTO; ELLIS, 2014: p. 16.

87 Ibid.: p. 16.

88 DIMENTO; ELLIS, 2014: p. 16.

89 NORTON, 2008: p. 254.

90 "adjust their physical layout (...) to the requirements of an automobile age." lbid.: p. 168. 




\section{II// 2. \\ A RODOVIA \\ NEGANDO A CIADADE}

"Precisamos tomar posse das margens da rodovia, tornando-a livre de desenvolvimento comercial irregular e obtendo para o benefício do motorista as vistas agradáveis e aspecto de campo, puro do desordenado clamor dos anúncios publicitários."

Benton MacKaye, 1930

"E a cidade se tornará um parque"

Le Corbusier, 1933 



\subsection{A CRISE DA CIDADE TRADICIONAL}

O fenômeno mundial de crescimento das populações urbanas acentuava o inchaço pelo qual passavam as cidades, que cada vez mais se aproximavam do colapso. Ao mesmo tempo que as cidades europeias, já inchadas, reduziam o ritmo de crescimento populacional, as cidades na América cresciam a taxas exorbitantes. Cidades como Chicago, Buenos Aires e São Paulo tornavam-se rapidamente grandes metrópoles, numa velocidade maior que a dos investimentos necessários em infraestrutura, resultando em um ambiente urbano à beira do caos.

\begin{tabular}{|l|r|r|r|r|}
\hline & 1870 & 1900 & 1930 & Crescimento (\%) \\
\hline Londres & 3.270 .000 & 4.500 .000 & 4.800 .000 & $47 \%$ \\
\hline Paris & 1.850 .000 & 2.700 .000 & 2.890 .000 & $56 \%$ \\
\hline Nova lorque & 1.480 .000 & 3.400 .000 & 6.930 .000 & $368 \%$ \\
\hline Chicago & 300.000 & 1.700 .000 & 3.380 .000 & $1.027 \%$ \\
\hline Buenos Aires & 178.000 & 950.000 & 2.400 .000 & $1.248 \%$ \\
\hline São Paulo & 31.000 & 240.000 & $950.000^{*}$ & $2.965 \%$ \\
\hline
\end{tabular}

Tabela 1 | Crescimento populacional urbano entre 1870 e 1930

Antes da difusão do uso do automóvel, os grandes centros urbanos do ocidente possuíam densidades que hoje são inimagináveis. Nos Estados Unidos, grandes cidades como Nova lorque, Filadélfia e Boston chegaram a densidades de 200.000 habitantes por quilômetro quadrado. ${ }^{2}$. Áreas comerciais e residenciais se misturavam. A elite urbana assim como profissionais liberais e artesãos habilidosos vivam e trabalhavam no centro da cidade, enquanto a classe operária vivia amontoada em cortiços $^{3}$.

Ao final do século XIX, cidades de alta densidade populacional tinham nas questões sanitárias um sério problema. Ideias difundidas acerca do assunto no período culpavam a forma das cidades como principal causa dos problemas. Na década de 1870, as casas em renque, comuns nas cidades norte-americanas, eram percebidas como moralmente, fisicamente e socialmente insalubres. Estudos realizados por médicos durante a segunda metade do século XIX mostravam que mortes eram mais comuns em áreas de habitação mais densa, em casas com más condições de ventilação e iluminação natural. Profissionais da área de saúde apontavam para mudanças no ambiente urbano como principal forma de

1 Fonte: Wikipedia. A data dos dados foi aproximada para possibilitar a comparação dos dados. As datas precisa são: Londres (1871,1900,1930), Paris (1872,1901, 1930), Nova lorque (1870, 1900, 1930), Chicago (1870, 1900, 1930), Buenos Aires: (1869, 1904, 1936), São Paulo (1872, 1900, 1920-1940*). *Foi feita uma média entre os censos de 1920 e 1940, já que não existem dados de 1930

2 BOTTLES, 1987: p, 06. Como comparação, Nova lorque nos anos 1980 possuía densidade de 90.000 habitantes por quilômetro quadrado

3 Ibid.: p. 06. 
combate a doenças nas cidades dos Estados Unidos. Esse conceito foi amplamente difundido e assimilado pela opinião pública, que buscava nos locais de residência abundância de iluminação e ar puro ${ }^{4}$. Ao mesmo tempo, assim como as ultrapassadas teorias biológicas de "geração espontânea" - que acreditavam na capacidade de ambientes insalubres em gerar espontaneamente seres vivos, como larvas insetos - bairros degradados eram considerados elementos "atratores" de pobreza.

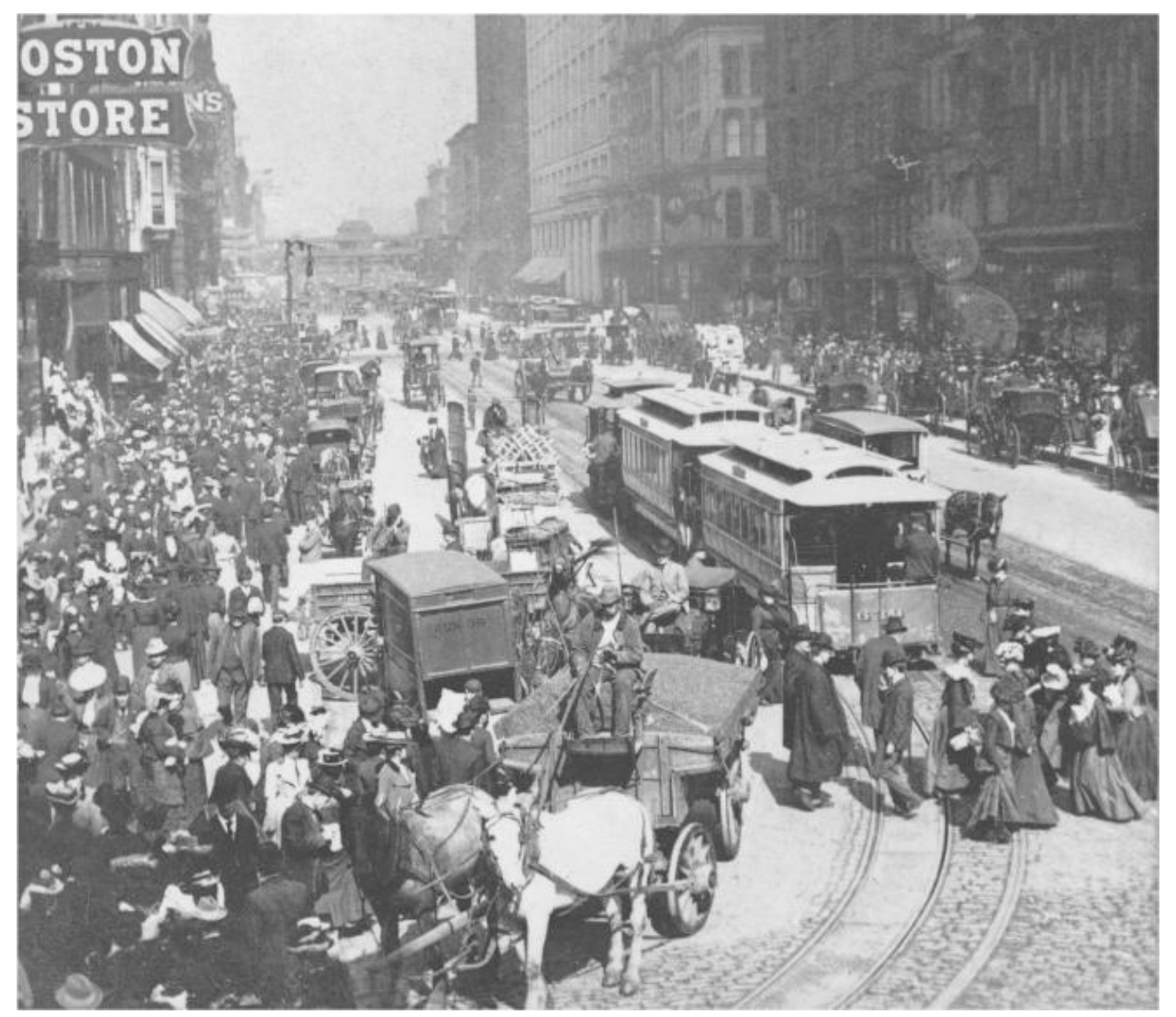

Figura 09 | Chicago, 1907

Consequência da crise decorrentes do crescimento urbano, a partir da década de 1920, foi possível constatar numericamente pela primeira vez nos Estados Unidos que os subúrbios estavam se desenvolvendo mais rápido do que as cidades base ${ }^{5}$. Numa reação ao crescimento industrial e ao aumento populacional das metrópoles, famílias de classe média passaram a deixar os grandes centros urbanos em direção a "bairros de classes segregadas" nos arredores ${ }^{6}$. Ao mesmo tempo que o aumento da frota norte-americana de automóveis tornava o trânsito das áreas centrais cada vez mais congestionado, o automóvel particular tornava mais fácil ao trabalhador comum morar mais longe do emprego, tornando este meio de transporte peça fundamental de uma nova forma de constituição urbana. 
Steven Conn, em seu livro "Americans Agains the City-Anti-Urbanism in the Twentieth Century," retrata alguns fundamentos presentes na história e na cultura norte-americana que levaram ao espraiamento urbano dos subúrbios, no que ele chama de "antiurbanismo". $\mathrm{O}$ autor remete a conceitos defendidos pelo "founding father" ${ }^{\prime \prime}$ Thomas Jefferson, que descrevia a figura mítica do fazendeiro yeoman - que cultiva sozinho sua própria terra como símbolo da liberdade e individualidade. Jefferson via a cidade como símbolo da força do Estado ${ }^{8}$, contrapondo-a à liberdade e à livre iniciativa individual, tão caras aos ideais fundadores norte-americanos.

O individualismo como valor nacionalista norte-americano também foi apropriado pelo lobby automobilístico. Afinal, como afirma Peter Norton, "o carro era o veículo mais individual, e dava a seus ocupantes mais liberdade que qualquer outro meio de transporte. (...) Com a ânsia americana pela liberdade do indivíduo, o automóvel foi a escolha natural dos americanos" ${ }^{9}$. Albert Reeves, gerente da NCAA - National Automobile Chamber of Commerce - aproximava o individualismo do automóvel aos valores norte-americanos: "a América está convertida ao transporte sobre pneus" porque "o transporte flexível e independente possibilitado pelo veículo a motor possui apelo inerente a um povo independente" ${ }^{10}$.

Em contrapartida, de acordo com Conn, a grande cidade industrial norte-americana marcaria um contraponto à primazia do indivíduo na cultura nacional. A criação de uma esfera pública, possibilitada pela densidade de uma grande cidade, permite aos indivíduos conceber a si mesmos como parte de um todo, maior e comum. Defensores das cidades pretendiam viabilizá-las ampliando os mecanismos de controle do Estado que possibilitassem a tomada decisões em grande escala, como a construção de redes de infraestrutura $^{11}$. A vida urbana remetia ao coletivismo, a uma existência cooperativa ${ }^{12}$. Foi em meio a grande diversidade étnica, racial e cultural, viabilizada pelas políticas de incentivo à imigração, que se definiu o éthos das grandes cidades norte-americanas, tornando-as definitivamente cosmopolitas.

É na cidade grande que o antiurbanismo ganha força. Alguns pensadores do período acreditavam genuinamente que as condições de caos e insalubridade das cidades eram absolutamente desumanas. Outros não se sentiam tão confortáveis vivendo em meio à multidão, compartilhando o espaço urbano com os demais cidadãos ${ }^{13}$. Como colocaram Morton e Lucia White em "The Intellectual Versus the City", conforme crescia, o ambiente urbano se tornava - para os antiturbanistas -, a "ovelha negra" da cultura norte-ameri-

7 São os "pais fundadores" dos Estados Unidos as grandes lideranças responsáveis pelo processo de independência do país em 1776.

8 Disse Jefferson em Notes on the State of Virginia: "As multidões das grandes cidades adicionam muito ao apoio do puro governo, como feridas fazem para a resistência do corpo humano. São os modos e espírito de um povo que preservam uma república em vigor. A degenerescência nestes é um cancro que come e em breve o coração de suas leis e constituição". Apud. CONN, 2014: p. 11.

9 NORTON, 2008: p. 205.

10 "America is converted to rubber-tire transportation," he explained, because "the flexible independent transportation afforded by the motor vehicle appeals inherently to an independent people.." Ibid.: p. 206.

11 Ibid.: p.05.

12 Ibid.: p. 61

13 Ibid.: p.05. 
cana; contra as cidades o medo costumava ser a reação mais comum ${ }^{14}$. White e White também afirmaram que o movimento antiurbano contava com a participação de "algumas das mais talentosas e influentes mentes" ${ }^{115}$ ao longo da história do país. Não apenas, os autores afirmaram que "os grandes escritores dos Estados Unidos não levantaram em conjunto para celebrar a metrópole norte-americana com entusiasmo" ${ }^{16}$, pelo contrário, retratavam os defeitos das cidades através de ideias de âmbito estético, psicológico e mora $\left.\right|^{17}$. Tal fato certamente influenciou a relação da cultura com a sua postura perante a cidade tradicional. Nos Estados Unidos do início do Século XX, por todos os lados se ouvia lamentações sobre a crescente impessoalidade do ambiente metropolitano, onde perdiam-se as noções de individualidade e vida em comunidade ${ }^{18}$ na mesma proporção em que a cidade crescia. Em "As Grandes Cidades e a Vida do Espírito" ${ }^{19}$, Georg Simmel elabora ideias sobre tais aspectos criticados pelos antiurbanistas.

De acordo com o autor, as relações entre os homens seriam diferentes nas grandes cidades, se comparadas às pequenas, "onde a existência é fundada sobretudo nos sentimentos e nos laços afetivos" ${ }^{20}$ entre os indivíduos. Para Simmel, estabelecem-se na grande cidade, relações mais racionais - e menos afetivas - entre os homens, ditadas pelo que ele chama de "economia monetária". Como afirma o sociólogo, "se as relações afetivas entre as pessoas se fundam em sua individualidade, as relações racionais tornam os homens elementos de cálculo, indiferentes em si mesmos e só tendo interesse pelo seu rendimento, grandeza objetiva" ${ }^{21}$. Para ele, "o princípio do dinheiro permanece fechado a qualquer individualidade dos fenômenos. Pois o dinheiro só se interessa pelo que é comum, a saber, o valor de troca que nivela qualquer qualidade, qualquer peculiaridade, colocando só a questão da quantidade." ${ }^{22}$. Com isso, o homem que vive nesse contexto

"se tornou insensivel às diferenças entre as coisas. (...) É que a significação e o valor dessas diferenças e, pois, das próprias coisas, para ele resulta negligenciável. (...) É o reflexo subjetivo da economia monetária em seu apogeu; o dinheiro, compondo uniformemente a diversidade das coisas, exprimindo as diferenças de qualidade por meio de diferenças quantitativas, arrogando-se o papel de denominador comum de todos os valores, converte-se no mais terrível de todos os elementos igualadores e rói irremediavelmente o coração das coisas, sua individualidade, seu valor específico, sua originalidade." ${ }^{23}$

\footnotetext{
14 WHITE; WHITE, 1962: p. 01-2.

15 "some of our most talented and most influential minds." WHITE; WHITE, 1962: p. 02.

16 "America's major writers did not rise up in a body to greet the American metropolis with enthusiasm." Ibid.:

p. 02.

17 Ibid.: p. 236.

18 Ibid.: p. 189.

19 Esse texto sintetiza muitas das ideias de seu livro "A Filosofia do Dinheiro", publicado em 1900.

20 SIMMEL, in. CHOAY, 1965: p. 330.

21 Ibid.: p. 331.

22 Ibid.: p. 331. Suas análises acerca da relação do homem com a "economia monetária" partem do conceito do "fetiche da mercadoria" de Marx: "Uma relação social definida, estabelecida entre os homens, assume a forma fantasmagórica de uma relação entre coisas (...). Aí, os produtos do cérebro humano parecem dotados de vida própria, figuras autônomas que mantém relações entre si e com os seres humanos. (...). Chamo a isto de fetichismo, que está sempre grudado aos produtos do trabalho, quando são gerados como mercadorias. É inseparável da produção de mercadorias." MARX, 1989: p.81.
}

23 SIMMEL, in. CHOAY, 1965: p. 332-333. 
A partir desse sentimento, afirma Simmel, surge no homem metropolitano um mecanismo de defesa que faz com que ele tenda a se afastar do convívio com os demais, como forma de tornar a vida urbana suportável ${ }^{24}$. Essa condição faz com que o autor defenda a antipatia - também traduzida como blasé - como um mecanismo de defesa necessário ${ }^{25}$ para a vida nas grandes cidades. Afinal, as relações, que antes eram pessoais se tornam para o citadino laços "quantitativos", onde o homem urbano se vê obrigado a lidar com "pessoas com quem a sociedade o obriga a conviver" ${ }^{26}$. As possibilidades de uma nova experiência de vida urbana propiciadas pelo automóvel auxiliam o sujeito a se isolar do convívio social. Ele passa a ver no automóvel uma nova forma de deslocamento sem que haja necessidade se misturar aos demais, que concede ao indivíduo plena liberdade de rápida locomoção. Roy Chaplin, da Hudson Motor Car Company, chega a firmar que "o automóvel propicia um sentimento de escape dessa supressão do indivíduo. É por isso que o público norte-americano tem aproveitado as viagens motorizadas tão rápido e com tanta intensidade" ${ }^{27}$. Assim sendo, podemos caracterizar o automóvel - a partir da leitura de Simmel - como um artefato urbano "antipático." Mais do que isso, o autor destaca que o isolamento do citadino - reforçado pelo automóvel e incentivado pelos antiurbanistas - aumenta sua sensação de liberdade: "a indiferença de uns em relação aos outros, que são a consequência de um meio em grandes dimensões - nunca favorece de modo mais sensível a independência do indivíduo, a não ser dentro da agitação das grandes cidades" ${ }^{28}$.

Os antiurbanistas advogavam em favor da retomada do conceito de "comunidade", tão hostis à esfera pública urbana quanto à forte presença do estado, fundamental ao bom funcionamento das grandes estruturas urbanas. A grande cidade representava a perda das relações sociais mais íntimas, substituídas pelo anonimato. Eles estavam convencidos de que não seria possível atingir um verdadeiro senso de "comunidade" na cidade moderna industrial; era preciso deixá-la, como vemos nas palavras de Henry Ford:

"A cidade não tem alma; é artificial; não é uma comunidade; é um crescimento pestilento; deveria ser abandonada para o campo; é absolutamente dependente

24 "Se aos contatos incessantes com inúmeros indivíduos devessem responder outras tantas reações interiores, como sucede nas pequenas cidades, (...) acabaríamos por nos atomizar completamente e por ficar em um estado psíquico impossível de imaginar. (...) É em função destas condições psicológicas e da desconfiança que temos direito de sentir diante dos elementos díspares e fugidios da vida urbana que nos vemos coagidos a essa reserva, que [por exemplo] nos faz com que nem conheçamos de vista vizinhos que moram em nosso prédio". SIMMEL, in. CHOAY, 1965: p. 333.

25 "Há por trás dessa reserva visível uma leve aversão, um sentimento de estranheza e repulsão diante do próximo, sentimento que, no momento de se produzir um contato mais estreito (...) mudaria imediatamente em hostilidade e ódio. (...) É desses dois perigos característicos da civilização urbana que nos protege a antipatia (...). É ela que cria as distâncias que mantemos com os demais e a necessidade que temos de nos desviar deles, sem o que nossa existência seria impossível. (...) O que, à primeira vista, parece surgir da dissociação, no fundo é tão-somente uma das formas elementares adotadas pela socialização". Ibid.: p. 333-334).

26 Ibid.: p. 331.

27 "The automobile supplies a feeling of escape from this suppression of the individual. That is why the American public has seized upon motor travel so rapidly and with such intensity." Citado por NORTON, 2008: p. 205.

28 No entanto, o próprio autor alerta que: "o fato de nela [a grande cidade] nos sentirmos às vezes mais solitários, mais abandonados que em qualquer outro lugar é evidentemente apenas o reverso dessa liberdade, já que neste, como em outros casos, de modo algum é necessário que a liberdade do homem se reflita em seu bem-estar". Ibid.: p. 335. 
do campo; está condenada à extinção"; "a solução final será o abandono como um engano"; "nós devemos resolver o problema da cidade deixando a cidade" 29

O conceito de "comunidade" implica algo mais profundo do que uma mera associação, sendo também compreendido emocional e espiritualmente, como um local onde todos sabem seu nome e se preocupam com você $\hat{e}^{30}$. Na mesma medida, "comunidades" são também definidas por aqueles que elas excluem. Elas se tornam formas de segregar minorias étnicas, raciais e religiosas do convívio das classes dominantes, como se elas não existissem. Para Françoise Choay, o urbanismo como ciência tem origem reativa: foram as rápidas transformações pelas quais passavam as cidades que levaram diversos profissionais a observar e refletir acerca da questão urbana ${ }^{31}$. Diferentemente do que ocorreria a partir da década de 1960, quando um grande número pensadores passaria a defender características da cidade tradicional, a transformação radical do espaço urbano pairava como conceito dominante no pensamento urbanístico. Nas palavras de Choay,

"O que é expressão de desordem chama sua antítese, a ordem. Assim, veremos oporse, a essa 'pseudodesordem' da cidade industrial, propostas de ordenamentos urbanos livremente construídas por uma reflexão que se desdobra no imaginário. Por não poder dar uma forma prática ao questionamento da sociedade, a reflexão situa-se na dimensão da utopia; orienta-se nela segundo duas direções fundamentais do tempo, o passado e o futuro, para tomar as formas da nostalgia ou do progressismo'32

É notável como durante esse período era comum às principais vertentes urbanísticas a defesa de alguma forma de isolamento como solução para a cidade futura. Parece ser desejo de diversos pensadores desse período dispersar a grande cidade, tornando o automóvel elemento fundamental de qualquer nova forma de organização urbana. Nesse contexto, como apontam DiMento e Ellis, a substituição do tecido da cidade tradicional para a construção de vias expressas urbanas aparentava ser um benefício social inquestionável. Para os profissionais ligados à questão urbana-desde engenheiros até arquitetos e planejadores - a velha cidade industrial era um obstáculo a novas e mais salubres formas de vida urbana. Vias expressas poderiam ajudar a reverter o curso da decadência e criar novas formas para a era do automóvel ${ }^{33}$. Para os antiurbanistas, era preciso descentralizar a cidade, num retorno a uma vida rural onde cada família norte-americana possuísse sua própria casa e alguns acres para cultivar. Mais do que um estilo de vida, era uma defesa de valores morais, de independência, segurança e liberdade ${ }^{34}$. Ao mesmo tempo, eles eram entusiastas das possibilidades tecnológicas disponíveis no século XX, com destaque para a eletricidade e o automóvel. O modelo de cidade-jardim servia como referência: pretendia-se com o modelo suburbano reunir "todas as vantagens da vida mais ativa na cidade e toda a beleza e as delícias do campo" ${ }^{\prime 35}$. Elas permitiriam novas formas de vida urbana sem que as possibilidades econômicas, viabilizadas pela concentração das atividades comerciais, se perdessem ${ }^{36}$.

29 "The city lacks a soul; it is artificial; it is not a community; it is a pestiferous growth; it should be abandoned for the country; it is absolutely dependent on the country; it is doomed to extinction"; "the ultimate solution will be the abandonment as a blunder"; "we shall solve the city problem by leaving the city". Apud. WHITE; WHITE, 1962: p. 201.

30 CONN, 2014: p. 06.

31 CHOAY, 1965: p. 04.

32 Ibid.: p. 07.

33 DIMENTO; ELLIS, 2014: p. 57

34 CONN, 2014: p. 59-60.

35 HOWARD in CHOAY, 1965: p. 220.

36 Ibid.: p. 05. 


\subsection{AS RODOVIAS PARA AUTOMÓVEIS E SEU DESENVOLVIMENTO TECNOLÓGICO}

Mesmo antes do surto de crescimento das cidades norte-americanas e do surgimento do automóvel, os subúrbios buscavam proporcionar uma melhor qualidade de vida urbana às classes mais favorecidas. Um dos principais atrativos desse tipo de moradia, nem urbano, nem rural, eram os parques, construídos como forma de valorização dos loteamentos. Pretendia-se trazer através do pitoresco paisagismo romântico inglês a atmosfera do campo ao ambiente suburbano, tornando as moradias próximas aos parques um símbolo de status ${ }^{37}$. As parkways faziam parte desse sistema, tratavam-se de estradas destinadas ao uso exclusivo de carruagens, para que ricos cavaleiros pudessem trafegar em velocidade em seus momentos de lazer.

As primeiras parkways foram concebidas em meados do século XIX pelo paisagista norte-americano Frederick Law Olmsted, como percursos recreativos, destinados ao lazer, rodeados de vegetação. Olmsted baniu das parkways qualquer outro tipo de transporte, criando ao mesmo tempo um percurso ininterrupto que permitisse o veloz cavalgar sem que fosse necessário se preocupar com obstáculos ou cruzamentos. No projeto do Central Park de Nova lorque, Olmsted desenvolve percursos como este em seu interior. Nele foram concebidas soluções de transposição de cruzamentos em desnível que posteriormente serviriam de referência para as vias segregadas do século XX. O paisagista também isolava as vias do ambiente exterior, dificultando a visão e a entrada de outros ao longo do percurso ${ }^{38}$. Os sinuosos traçados rodeados de variações de elementos paisagísticos criavam uma paisagem cinética, uma experiência estética concebida para ser desfrutada em movimento. Elas representavam não apenas o desejo de contato com a natureza, mas também o prazer de conduzir um veículo em velocidade. Mesmo tendo surgido anteriormente ao automóvel, nelas estavam presentes os principais elementos das vias expressas modernas: limites de acesso, restrição a apenas uma classe de veículos, separação de níveis de cruzamento, assim como rampas de entrada e saída ${ }^{39}$.

No mesmo período, também em Nova lorque, Olmsted desenvolve um projeto para uma avenida semelhante, de uso exclusivo para carruagens, conectando o bairro do Brooklyn ao Prospect Park. Esses bulevares conectavam parques a espaços cívicos e eram desenvolvidos como vias principais de empreendimentos suburbanos, sem abrigar atividades comerciais ${ }^{40}$. Elas possuíam menos acessos que uma rua urbana tradicional,

37 MCSHANE, 1995: p. 30.

38 MCSHANE, 1995: p. 33.

39 Ibid.: p. 40.

40 De acordo com Brown, Morris e Taylor (2009: p.32) nesse período, incorporadores descobriram que o acesso a parques era capaz de incrementar o valor de venda de seus empreendimentos. Para tal, as parkways foram 
mas não poderiam ser consideradas vias de acesso limitado, por terem cruzamentos em nível $^{41}$, apesar de também serem denominadas parkways.

Ao permitir apenas a passagem de carruagens, as parkways de Olmsted pretendiam isolar os subúrbios de classes mais altas dos demais, como forma de preservar o ar "natural" do empreendimento $^{42}$. 0 padrão de construção de parques lineares com acesso limitado foi reproduzido em larga escala pelos Estados Unidos durante o final do século XIX, atingindo seu ápice na década de 1890, onde a segregação do acesso à pista se tornava cada vez mais limitada. No entanto, a popularização dos bondes elétricos como forma de viabilizar empreendimentos de subúrbio tornou as parkways obsoletas. Se comparados às carruagens - utilizadas apenas pelas famílias mais ricas -, bondes eram mais interessantes aos empreendimentos imobiliários, já que eram capazes de atrair também compradores sem tantos recursos para os subúrbios ${ }^{43}$. Por ironia do destino, as parkways para carruagens deixaram de ser construídas justamente na virada do século $X X$, quando os primeiros automóveis começavam a circular pelas ruas.

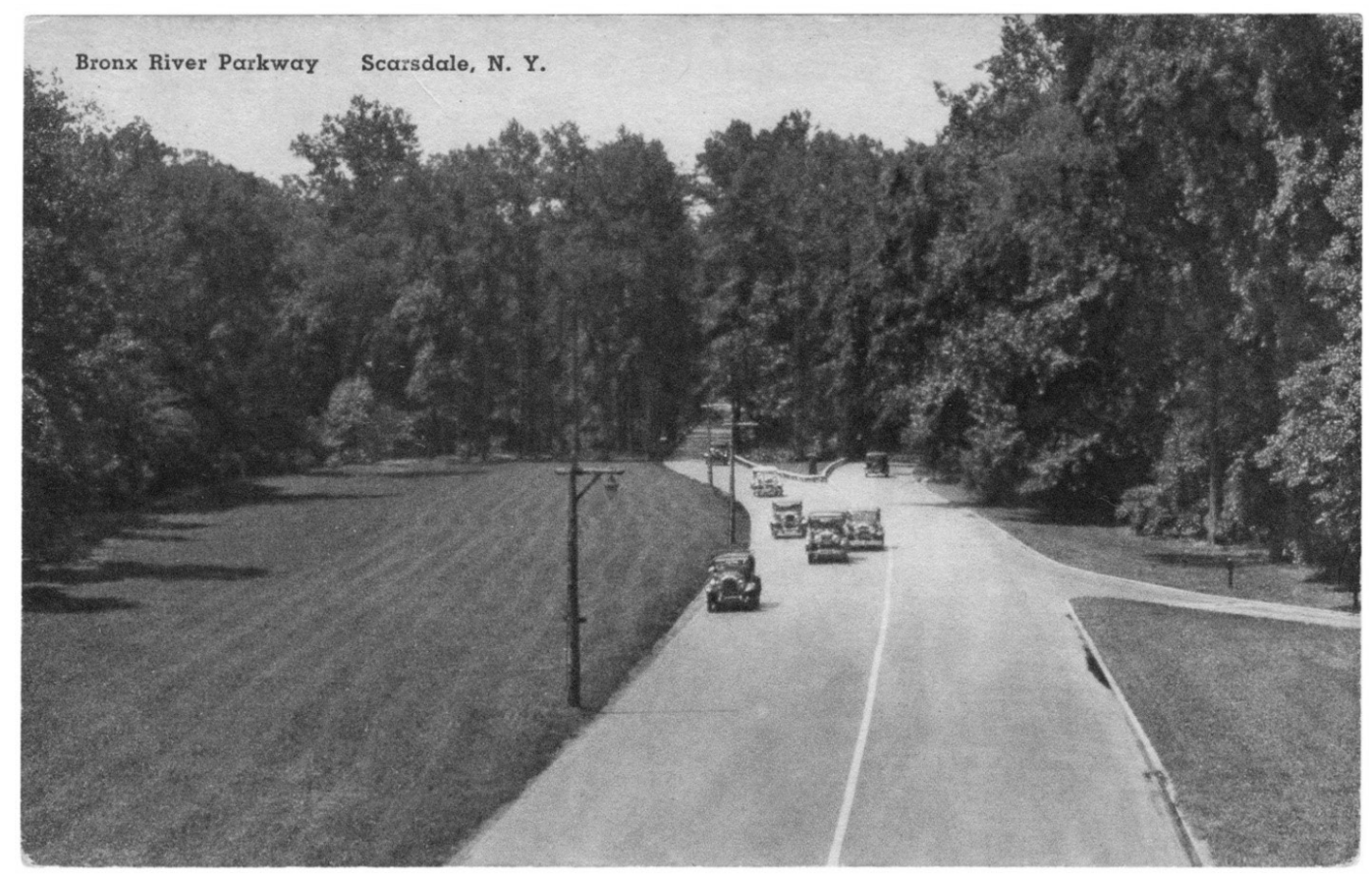

Figura 10 | Bronx River Parkway, sem data

No entanto, em 1907, iniciou-se, mais uma vez em Nova lorque, a construção da Bronx River Parkway, a primeira rodovia pública do seu tipo a ser construída especificamente para o uso do automóvel, como via de acesso limitado ${ }^{44}$. Ao recuperar a ambiência das parkways na concepção de rodovias exclusivas para automóveis,

\footnotetext{
construídas para melhorar essas conexões, tornando o percurso uma experiência em si própria.

41 DIMENTO; ELLIS, 2014: p.23.

42 MCSHANE, 1995: p. 35.

43 Ibid.: p. 36-7.

44 No mesmo ano começava a construção da Long Island Motor Parkway, a primeira rodovia de acesso limitado construída por iniciativa privada. Inaugurada em 1908, a via era tarifada e tinha função recreativa, utilizada apenas para corridas. HALL, 1988: p. 330.
} 
pretendia-se preservar na via expressa o caráter contemplativo, mantendo sua relação com a paisagem circundante, onde a experiência de dirigir ainda era considerada primordialmente atividade de lazer. O projeto começou integrado à concepção de um parque linear como restauração ambiental do poluído Rio Bronx, conectando o Norte de Manhattan com empreendimentos suburbanos de elite no condado de Westchester. Ao combinar o repertório formal nova-iorquino de parques e bulevares com as novas necessidades técnicas que permitissem fluidez ao tráfego de automóveis, seu projeto se tornou exemplo pioneiro, combinando a beleza da paisagem natural do parque com a segurança e rapidez da rodovia. Suas características se tornaram rapidamente referência para outros projetos do tipo, como a divisão de trechos de seu percurso com canteiros centrais sinuosos, ao mesmo tempo que evitava curvas excessivamente acentuadas. Com quatro faixas de rolamento, a rodovia contava com cruzamentos em desnível, pistas separadas, acessos limitados, sem a interferência de vias locais, ou acesso de estabelecimentos comerciais. Pontes eram elementos especiais que buscavam harmonia com o ambiente natura $\left.\right|^{45}$.

Também é importante destacar que as parkways eram de uso exclusivo de carros de passeio, conectando trechos urbanos específicos a pontos de lazer ou moradia suburbana de baixa densidade. Como afirmou Berman, o próprio desenho das pontes das parkways nova-iorquinas possuía gabarito baixo, de modo a impossibilitar a passagem de ônibus e caminhões pelo percurso. Tais vias se restringiam aos limites da cidade, nunca penetrando em seu interior. A transposição do conceito de via de acesso limitado para o sistema de rodovias, bem como para o viário urbano só ocorreria em momento posterior.

\section{AS RODOVIAS NORTE-AMERICANAS}

Paralelamente ao desenvolvimento das vias rápidas de lazer, as rodovias entre cidades foram responsáveis por outra vertente do desenvolvimento tecnológico da via expressa. Para os norte-americanos, a questão da construção de rodovias era fundamental para a expansão e ocupação de seu território. Desde o início do Século XIX, a construção de uma rede de "rodovias postais" que conectassem o país já eram alvo de discussão nas altas esferas políticas ${ }^{46}$. Em 1895, é fundado dentro do "Departamento de Agricultura" o Bureau of Public Roads ${ }^{47}$, com o objetivo de melhorar as estradas rurais norte-americanas, enquanto que ruas e avenidas urbanas mantinham seu planejamento e administração na esfera municipa $\left.\right|^{48}$. Sua missão principal era auxiliar na distribuição da produção rural em direção às cidades e construir um sistema nacional que interligasse pontos estratégicos do território. Dessa forma, a experiência da construção das primeiras estradas para automóveis se inicia através de sua inserção dentro da paisagem natural, onde muitas delas eram ainda construídas sem pavimentação. O desenvolvimento e estabelecimento das técnicas de projeto de rodovias tinham como desafio fundamental o enfrentamento das condições naturais dessa paisagem em um desenho que respeitasse antes de mais nada

45 WEINER, 2012: p. 9.

46 WEINGROFF, 2015: p. 03.

47 O nome pode ser traduzido para escritório de estradas públicas.

48 DIMENTO; ELLIS, 2014: p. 14. 
as características geográficas de cada local, preservando sobretudo os requerimentos de segurança e eficiência para que os automóveis pudessem trafegar nas rodovias em velocidade $^{49}$. Assim como nas áreas urbanas, durante as primeiras décadas de construção de rodovias, preponderava o papel do automóvel como veículo de lazer, ao invés de ser considerado um meio de transporte.

As primeiras estradas para automóveis foram construídas em trechos curtos e importantes ligações entre as cidades tinham falhas ${ }^{50}$ por conta de ações construtivas descoordenadas, tornando-as ineficientes aos motoristas ${ }^{51}$. Ademais, as estradas costumavam estar em péssimo estado de conservação. Em uma avaliação nacional realizada em 1904, apenas sete por cento das estradas eram consideradas "melhoradas", o que na época significava a presença de pedriscos ao invés da terra batida ${ }^{52}$. Em 1916, a situação começa a mudar, com o início do financiamento federal para a construção de estradas entre cidades com o Federal Aid Road Act, mas pouco foi realmente feito até a entrada dos Estados Unidos na Primeira Guerra Mundial, em $1917^{53}$. As estradas norte-americanas foram bastante demandadas durante os anos de guerra como meio de distribuição de mercadorias produzidas no país em direção aos portos, para serem enviadas à Europa. A péssima qualidade das vias ficou evidente, sendo a principal razão para o atraso da saída das embarcações. Produtos perecíveis chegavam a estragar por conta dos atrasos ${ }^{54}$.

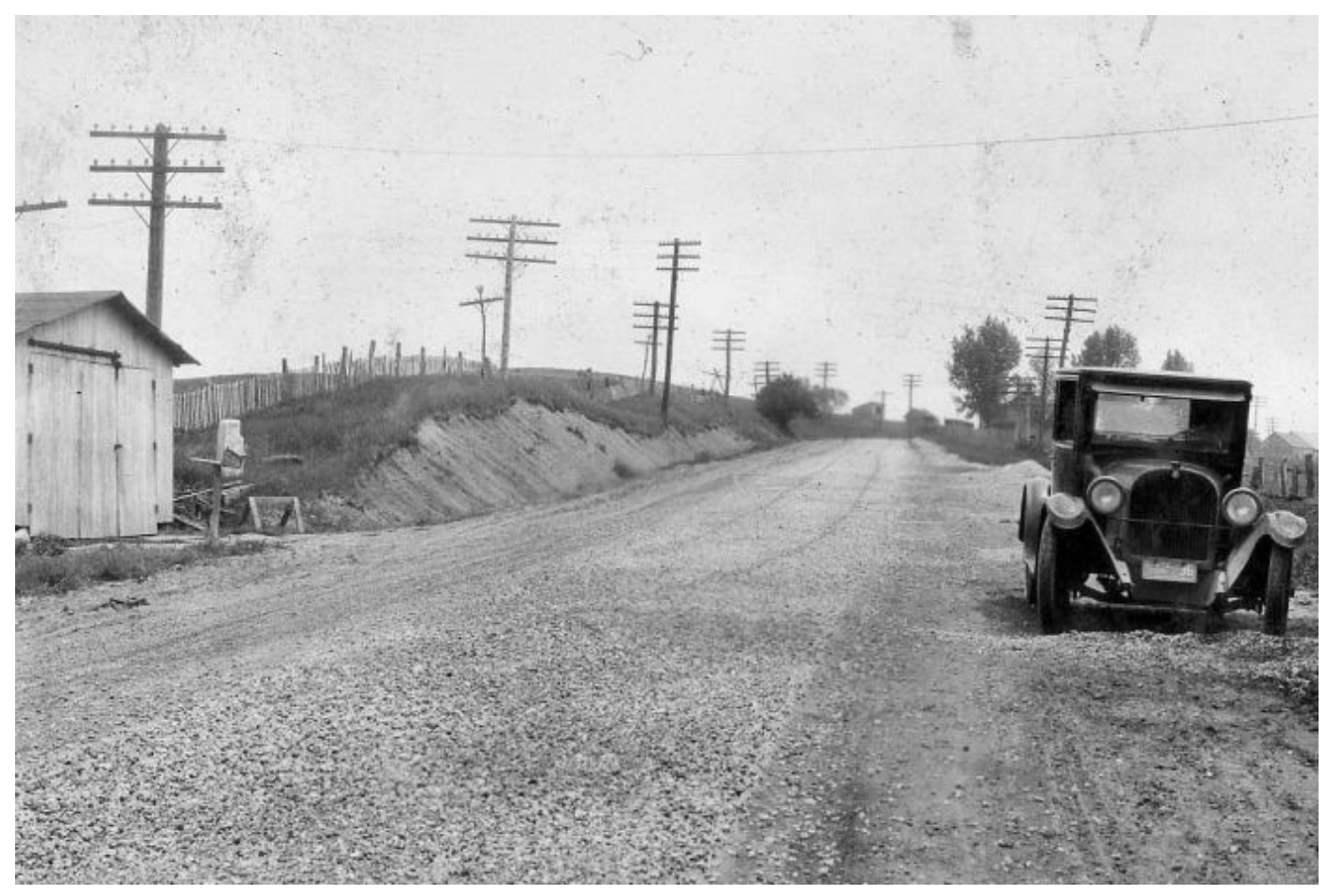

Figura 11 | Estrada nacional pavimentada com pedrisco em Ohio, 1917

DIMENTO; ELIIS, 2014: p. 26.

WEINER, 2012: p. 07.

FOSTER, 2003: p. 12

Ibid.: p. 12.

Ibid.: p. 12.

Ibid.: p. 12-3. 
As lições logísticas aprendidas com a guerra foram suficientes para convencer a esfera federal a investir mais em infraestrutura rodoviária ${ }^{55}$. A resposta veio em 1921, quando o Federal Highway Act estabeleceu o primeiro plano de construção de uma rede de rodovias entre estados abrangendo todo o país. A medida surtiu grande efeito: no início da década de 1930 já era possível atravessar o país de automóvel em vias pavimentadas de pista simples - com uma faixa em cada sentido - e os grandes centros populacionais do país já estavam conectados ${ }^{56}$.

A injeção de verba federal também dá força institucional para a American Association of State Highway Officials (AASHO) - fundada em 1914, com o objetivo de estabelecer padrões rodoviários para todo o país - e para o Bureau of Public Roads, que já contava com a chefia de Thomas H. MacDonald. Figura de destaque, MacDonald liderou os trabalhos do departamento por trinta e quatro anos - de 1919 até sua aposentadoria em 1953 -, tornando-se personagem fundamental no desenvolvimento rodoviário norte-americano, dentro e fora das cidades. Ambas as entidades se tornariam posteriormente referências mundiais no estabelecimento de diretrizes de projeto e construção rodoviária.

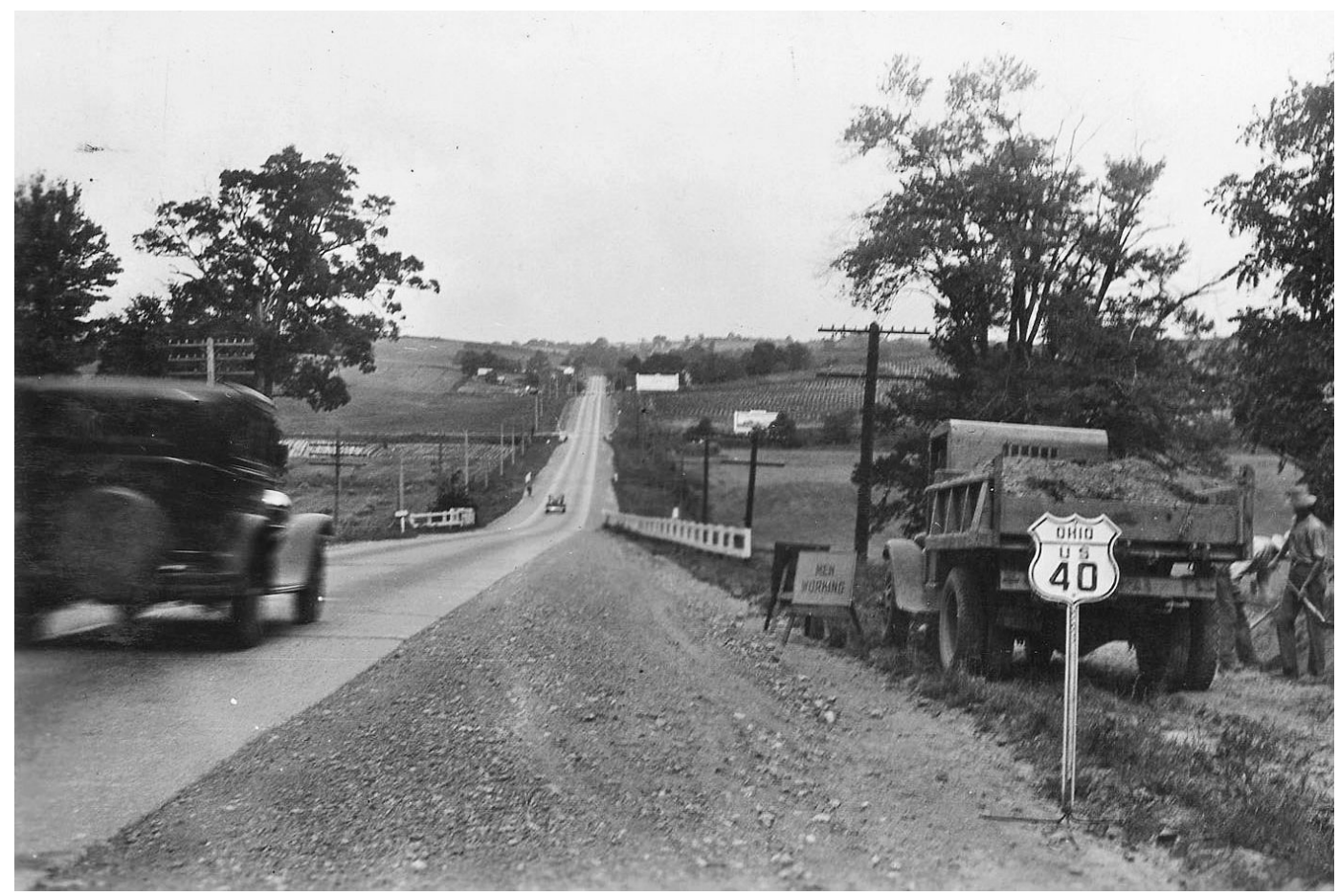

Figura 12 | Estrada nacional pavimentada em concreto em Ohio, 1933

Ao completar o "período pioneiro" da construção de rodovias, a atenção das instituições se voltou ao desenvolvimento de aspectos técnicos de projeto, para que as rodovias pudessem dar conta da maior quantidade de veículos trafegando nas estradas, bem como se adaptar às transformações tecnológicas dos automóveis, cada vez maiores, mais pesados e velozes. As primeiras estradas eram inadequadas às novas demandas por conta da pavimentação pouco resistente, que se deteriorava rapidamente, além de possuírem leitos estreitos demais para os novos veículos - mais largos - e dos traçados demasiadamente 
sinuosos, responsáveis pela grande quantidade de acidentes. Engenheiros de rodovias recebiam forte apoio da indústria automobilística e da construção civil, que colaboravam com o financiamento de pesquisas para o desenvolvimento tecnológico. Desde 1921, o Highway Research Board era uma instituição de prestígio que financiava, coordenava e disseminava a pesquisa na área de engenharia de rodovias. Nesse rápido período de tempo até o início dos anos 1930, esses profissionais estabeleceram uma imagem pública de alta credibilidade técnica e científica ${ }^{57}$ por conta das evoluções técnicas dos projetos e das obras rodoviárias por eles desenvolvidas.

\section{AS RODOVIAS EUROPEIAS}

Em contrapartida à situação norte-americana, o contexto europeu apresentava outros desafios. Num continente onde uma consolidada rede de estradas precedia a invenção do automóvel, a questão rodoviária estava ligada à pavimentação e à manutenção de estradas existentes. De forma mais acentuada que nos Estados Unidos, a prática automobilística era pautada como atividade esportiva, ligada ao lazer, onde motoristas realizavam o "turismo": grandes trajetos que muitas vezes extrapolavam seus países de origem. Desse modo, desde seu início a questão rodoviária já se apresentava como problema de ordem internaciona ${ }^{58}$. A França era considerada o epicentro automobilístico do continente. Paris, cidade que abrigava grande produção de veículos, se tornou uma das primeiras metrópoles europeias a receber em suas ruas uma frota expressiva de automóveis ${ }^{59}$. A capital era ponto de partida de diversas corridas internacionais, onde motoristas realizavam "tours" em direção a outras grandes cidades do continente. Motoristas de toda Europa viajavam até a França para rodar em seus automóveis sobre suas estradas, aclamadas pela sua excelência técnica e ótimo estado de manutenção. A região de Côte d'Azur foi a primeira a se abrir ao turismo automobilístico no início do século $X X$, de onde partiam trajetos em direção a países do sul da Europa, como a Itália e a Áustria ${ }^{60}$.

Por conta de sua importância, Paris recebia os principais eventos relacionados ao tema, como o primeiro Congresso Internacional de Automobilismo, realizado em 1900; tornando-se sede da Permanent International Association of Road Congress - PIARC - em 1908, onde mais de mil e seiscentos especialistas se reuniram para discutir pela primeira vez a questão da infraestrutura rodoviária em âmbito internacional ${ }^{61}$. Seu objetivo era: "favorecer os progressos na construção, manutenção, circulação e exploração comercial das rodovias, através da organização de congressos, da publicação de dissertações, relatórios e documentos diversos, bem como concentrar os resultados dos testes realizados nas estradas e nos laboratórios" ${ }^{\prime 62}$.

Dentre as discussões presentes, estavam tanto questões de padronização de sinalização de trânsito e documentação, quanto questões técnicas de construção de rodovias. A manutenção do pavimento, prejudicado pelo crescente número de automóveis, assim como o problema da poeira levantada pelos veículos nas estradas de terra eram algumas das principais

61 Dominados por profissionais europeus, os congressos da PIARC só contam com uma delegação norte-americana no evento de 1926. O evento posterior, de 1930 seria sediado em Washington. LAY e VANCE, 1992: p. 119.

62 ZIEGLER, 1998: p. 13. 
questões debatidas ${ }^{63}$. Outro ponto importante de discussão se referia à construção de novas estradas dedicadas exclusivamente ao uso do automóvel. Concluiu-se que seria mais favorável investir no melhoramento das vias existentes, postergando a construção das primeiras vias exclusivas para automóveis na Europa para o início da década de 1920, nos arredores da cidade de Milão, na Itália.

\section{AUTOSTRADAS ITALIANAS}

A Autostrada Milano-Laghi, considerada a primeira autoestrada da Europa, foi construída através de iniciativa privada, com apoio entusiasmado do governo fascista de Mussolini ${ }^{64}$. Com uma única pista recebendo os dois sentidos de tráfego, seu traçado possuía longos trechos em linha reta e cruzamentos em desnível, conectando a capital da Lombardia com o local de veraneio nos lagos alpinos. Tratava-se de uma via destinada a carros de lazer, permitindo aos motoristas que trafegassem com rapidez e segurança sem serem interrompidos. Esta primeira empreitada não foi a única: até os anos 1930 seriam construídos quinhentos quilômetros de rodovias exclusivas para automóveis na Itália, seguindo o mesmo modelo da rodovia pioneira, com uma única pista ${ }^{65}$.

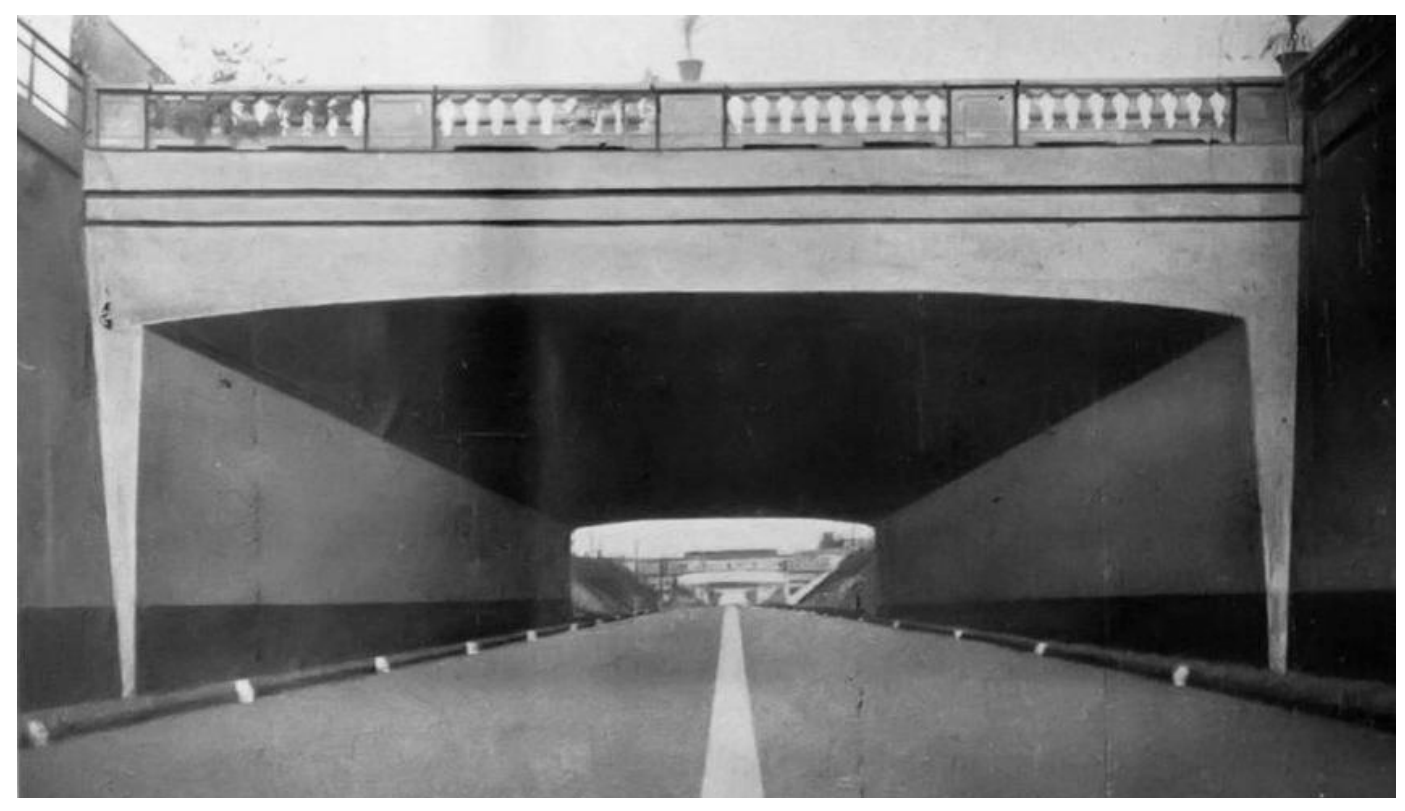

Figura 13 | Autostrada Milano Laghi-cruzamento em desnível

Por conta dos desenvolvimentos tecnológicos estabelecidos pela experiência italiana, o $5^{\circ}$ congresso da PIARC, de 1926, foi realizado em Milão para que os diversos técnicos internacionais pudessem conhecer melhor sua estrutura. Durante o evento as vias expressas italianas foram intensamente exaltadas. Consideradas avanços tecnológicos de grande importância, elas viabilizavam o aproveitamento do potencial automobilístico em

63 SCHIPPER, 2008: p. 67.

64 MORAGLIO, 2009: p. 171.

65 ZIEGLER, 1998: p. 12. Dentre as rodovias estão as rodovias Milão-Bergamo (1925-1927), Nápoles-Pompéia (1927-1929), Brescia-Bergamo (1928-1931), Turim-Milão (1929-1932), Floreça-Litoral (1928-1932), Veneza-Pádua (1930-1933) e Gênova-Serravalle (1933-1935). MORAGLIO, 2009: p. 175. 
seu máximo, carregando em si um verdadeiro significado modernizador. Nas palavras do presidente da associação:

"Nós viemos à Itália receber instruções, mas eu gostaria também de parabenizar os engenheiros italianos pelos resultados que eles já obtiveram (...). Eles serão os precursores para a criação de estradas especialmente para automóveis, tomando seu lugar na vanguarda do progresso." ${ }^{66}$

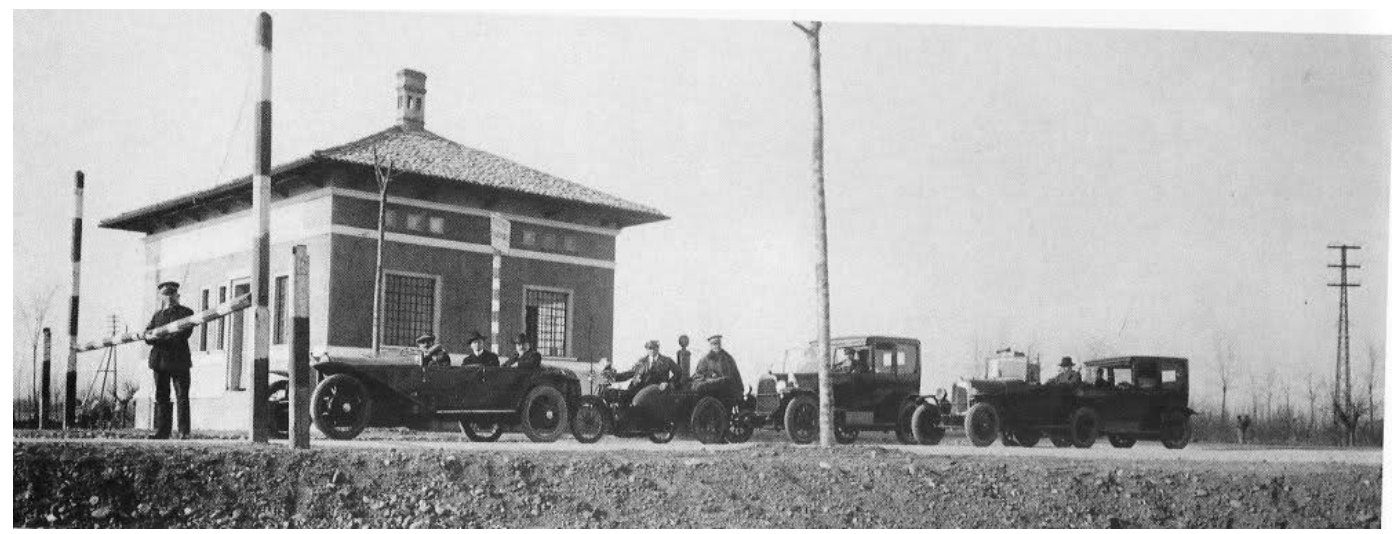

Figura 14 | Pedágio de acesso à Autostrada Milano Laghi

Contando com participação de membros do Bureau of Public Roads norte-americano, o congresso estabelece as noções essenciais que definem as rodovias exclusivas para o tráfego automotivo, calcadas nos princípios de velocidade, eficiência e segurança, desenvolvidos na experiência italiana. Segue trecho da resolução do congresso:

"A criação de estradas reservadas ao trânsito de automóveis pode ser justificada não somente em estradas comuns quando o trânsito misto na proximidade dos grandes centros, ou entre grandes centros, ou através de zonas com notável movimentação industrial, comercial ou turística, produz uma saturação ou um congestionamento perigoso à segurança da circulação ou contrária às economias dos transportes, mas também quando, com predomínio absoluto do trânsito de automóveis, é importante assegurar que, em geral, e em cada um de seus casos específicos, o máximo desempenho de que forem capazes em termos de velocidade, continuidade, segurança.

A auto-estrada deve ter autonomia absoluta e separação em relação às outras ruas e zonas vizinhas.

Podem ser aplicadas não só as regras comuns de polícia de trânsito, bem como aquelas da polícia ferroviária, quando houver proibição de entrada e de circulação.

Enquanto o tráfego de veículos a motor para mercadorias não se tornar extraordinariamente intenso, e desde que a estrada tenha largura que permita

66 "We have come to Italy to receive instruction, but I would like to also congratulate the Italian engineers on the results they have already obtained, to be exhibited tomorrow. They will be the precursors to the creation of roads specially for automobiles, taking their place in the vanguard of progress."Apud. MORAGLIO, 2009 : p. 175. 
os veículos leves possam ultrapassá-lo, mantendo sua própria mão, não é necessária nem desejável a separação das circulações de veículos leves e pesados em diferentes faixas.

Travessias em nível devem ser excluídas absolutamente. A continuidade destes deve ser assegurada por passagens superiores ou inferiores.

É desejável que os veículos entrando e saindo pelas alças de acesso à estrada não atravessem a faixa reservada para o sentido oposto; no entanto, estes cruzamentos podem ser efetuados sem problemas através da rigorosa disciplina de circulação e manobra que seja própria da autoestrada ${ }^{67}$.

Contudo, apesar do grande desenvolvimento tecnológico que representavam, tais empreendimentos não eram mais do que trechos isolados, desarticulados, sem conformar uma rede nacional de rodovias. Sua construção partia de interesses de políticos locais, aliados com a iniciativa privada. Como negócio, as autoestradas receberiam recursos somente através de pedágios. No entanto, devido ao baixo número de veículos em circulação naquele período, tais rodovias ficaram longe de se tornarem lucrativas. Em algumas delas, demorava-se mais de quinze minutos para ver um carro passar. Engenheiros visitantes, curiosos para conhecer as novas obras de engenharia italianas perguntavam: "Onde está o trânsito? Por que foram construídas essas autoestradas?" 68 . Posteriormente, sob a sombra da crise de 1929, Mussolini interrompe a construção de novas rodovias, que não seriam retomadas tão cedo naquele país.

\section{AUTOBAHNEN ALEMÃS}

Os alemães também tiveram papel pioneiro na construção de autoestradas na Europa. A Automobil-Verkehrs-und-Übungs-Straße-AVUS, construída em Berlim entre 1913 e 1921 é considerada a primeira via exclusiva de automóveis da Europa. Com dez quilômetros de extensão, tratava-se de uma pista de corrida: seu fim era dotado de uma curva em "u", com altíssima declividade transversal, para que os automóveis pudessem prosseguir no sentido inverso em circuito. No entanto, por conta de seu comprimento, a via também era utilizada para conectar Berlim ao subúrbio ${ }^{69}$. Devido ao seu pioneirismo, alguns de seus atributos seriam posteriormente utilizados como referência para projetos rodoviários na década seguinte $^{70}$. Assim como na Itália, durante a década de 1920 foram desenvolvidos por entes privados planos para a construção de autoestradas, incluindo um plano ambicioso para uma rede de vinte e cinco mil quilômetros. A primeira Autobahn a ser construída teve suas obras concluídas antes da ascensão nazista ao poder, em 1933, ligando as cidades de Bonn e Colônia. Posteriormente, ao compreender as possibilidades militares da comunicação entre cidades através de rodovias de alta velocidade, os nazistas construíram as autoestradas projetadas na década anterior em ritmo alucinante: três mil e trezentos quilômetros até o

\footnotetext{
67 MAIA, 1930: p. 325. Traduzido para o português a partir do original, em italiano.

68 Ibid.: p. 175-7.

69 SCHIPPER, 2008: p. 67-8; HALL, 1988: p. 333

70 Ibid,
} 
início da Segunda Guerra ${ }^{71}$. Diferentemente do modelo italiano, a construção de rodovias alemãs se concentrava inteiramente nas mãos do poder público. De acordo com o historiador e professor Massimo Moraglio, o programa de rodovias alemão só foi possível devido ao regime político autoritário nazista, que foi capaz de impor tamanho empenho de verba pública nesse empreendimento sem questionamentos. Segundo ele, não seria possível encampar tamanho projeto de infraestrutura na década de 1930 sem que existisse uma política de apropriação de riquezas por parte do estado, tanto dentro da própria Alemanha quanto nos países invadidos durante a guerra ${ }^{72}$.

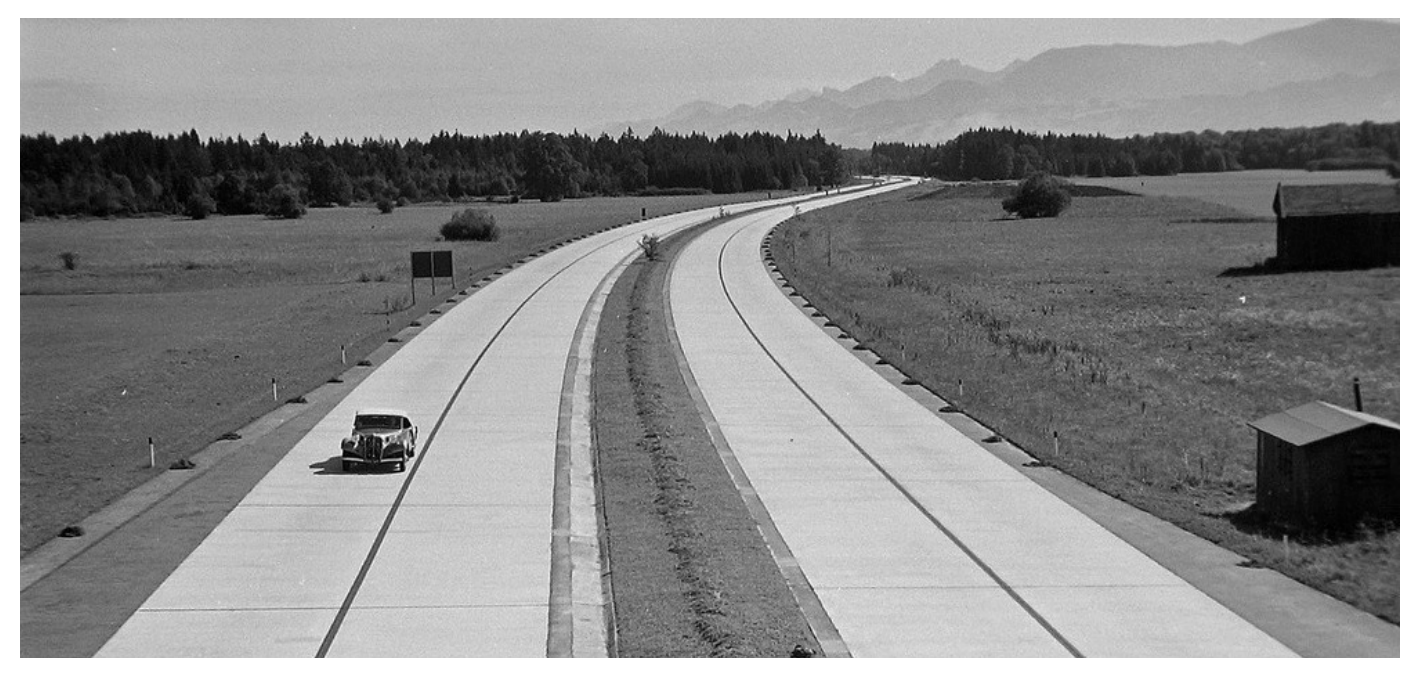

Figura 15 | Autobahn Alemã, 1937

Apesar de seus projetos serem ainda muito diferentes das rodovias atuais do ponto de vista tecnológico, foram as Autobahnen que criaram uma nova paisagem viária que serviu de referência para o seu posterior desenvolvimento tecnológico em âmbito internacional. Mesmo com duas pistas - uma para cada sentido de tráfego - as Reichsautobahnen eram diferentes das autostradas italianas. Como as ferrovias, as vias de trânsito rápido tinham traçado objetivo sobre a paisagem natural, dividindo a rodovia em duas pistas, mantendo sua largura constante. Em nome da eficiência de seu traçado as rodovias ganhavam caráter mais objetivo e de maior escala. Suas motivações militares e econômicas a afastavam do automobilismo esportivo, utilizando as autoestradas como forma eficiente de conexão entre cidades, com pistas largas e grandes raios de curvatura para altíssimas velocidades. De acordo com escritor Earl Swift ${ }^{73}$, o estilo das rodovias de acesso limitado alemãs era "discreto e modernista" e a escala de suas pontes e viadutos era "monumental"74.

Nos Estados Unidos, Miller McClintock aponta para as autoestradas alemãs como grande referência: "temos muito o que aprender com o que a Alemanha já construiu com suas magníficas Autobahnen"75. O teórico norte-americano afirmava que "apenas uma

71 HALL, 1988: p. 333-4.

72 MORAGLIO, 2009: p. 179.

73 Autor do livro "The Big Road - The Untold Story of the Engineers, Visionaries, and Trailblazers Who Created the American Superhighways"

74 SWIFT, 2011: p. 132

75 "We have much to learn from what Germany has done with her magnifi cent Autobahnen."Apud. NORTON, 2008: p. 262. 
abordagem dessas trará algo como uma solução permanente para o problema dos acidentes e do trânsito" ${ }^{76}$.

O chefe do Bureau of Public Roads, Thomas H. MacDonald esteve duas vezes na Alemanha durante a década de 1930 para visitar as Reichsautobahnen do regime nazista, definidas por ele como "maravilhosos exemplos da melhor construção de rodovias modernas" "desenho simples de linhas agradáveis" ${ }^{78}$ atraiu a atenção do engenheiro de rodovias, que também se encantou com a forma como a vegetação circundante mascarou a paisagem industrial do vale do rio Ruhr. Para ele, não havia dúvidas de que os alemães estabeleciam um novo patamar na concepção de planejamento e projeto rodoviário de larga escala ${ }^{79}$.

A ampla repercussão das Reichsautobahnen nos Estados Unidos acabou influenciando a política de construção de rodovias no país. No final da década de 1930, MacDonald chegou a ser convidado para uma visita à Casa Branca para discutir com o presidente Franklin Roosevelt a construção de um sistema de rodovias expressas nacionais que conectasse os extremos do país, resultando no relatório Toll Roads and Free Roads, fundamental para o desenvolvimento da construção do sistema interestadual de vias expressas norte-americanas, e que será detalhado mais adiante.

76 "only such an approach will bring about a permanent solution of the problem of accidents and congestion" NORTON, 2008: p. 262.

77 "Wonderful examples of the best modern road building."Apud. SWIFT, 2011: p. 132.

78 "plain design of pleasing lines." Ibid.: p. 132.

79 Ibid.: p. 132. 


\subsection{FUGERE URBEM: O URBANISMO A PARTIR DA RODOVIA}

Com as possibilidades abertas pela rodovia moderna, certos urbanistas desenvolveram propostas alternativas à cidade tradicional. Numa mistura entre passado e futuro, as mais modernas técnicas de circulação atravessariam uma paisagem pré-industrial, onde as aglomerações urbanas surgiriam em meio à paisagem agrícola ou natural. Nesse modelo de urbanismo, a estrada se torna um local asséptico, sem vestígios de vida humana. Ao mesmo tempo, nas aglomerações urbanas o automóvel se isola das demais atividades. Esse novo urbanismo rompe com a escala que a cidade possuía até então, imaginando cidades altamente controladas, tanto do ponto de vista do seu planejamento e crescimento quanto do seu desenho, densidade, das suas funções e atividades.

\section{O PLANEJAMENTO REGIONAL DA RPAA}

Os planejadores da RPAA - Regional Planning Association of America-, uma pequena, porém influente associação de planejadores de Nova lorque, tiveram importante papel na defesa desses conceitos, entre as décadas de 1920 e 1930. Eles compartilhavam da mesma hostilidade em relação às grandes cidades, defendendo a descentralização das aglomerações urbanas em forma de pequenos núcleos interligados, agrupados em forma de "regiões" 80 . Lewis Mumford, membro da RPAA e defensor da vida urbana, em seu The Culture of Cities, enxergava o automóvel como um positivo liberador dos moradores presos às cidades industriais. Rodovias regionais planejadas em rede seriam capazes, segundo o autor, de "quebrar as hipertrofiadas massas urbanas sem função do passado", através da substituição de uma "cidade mononucleada" por uma "cidade polinucleada" ${ }^{81}$. O conceito partia de ideias mais amplas sobre urbanismo e a forma de vida nas cidades norte-americanas, buscando descentralizar as grandes metrópoles através da criação de uma cidade regional formada por um núcleo principal rodeado de "cidades-satélite". Cada agrupamento urbano seria composto de áreas de trabalho e residências, rodeadas por um cinturão verde de parques, fazendas e florestas. Pretendia-se também descentralizar os equipamentos de escala metropolitana, distribuindo-os de forma equivalente entre os centros. Dessa forma, pretendia-se dar importância regional a cada uma das cidades-satélite, transformando o conjunto em uma rede equilibrada de assentamentos urbanos. Tratava-se de um modelo muito diferente do padrão de suburbanização que de fato tomou conta dos Estados Unidos na segunda metade do século XX, onde as aglomerações urbanas eram apenas cidades-dormitório, gerando um grande movimento pendular entre casa e trabalho ${ }^{82}$. 
Para os membros da RPAA, ao possibilitar novas formas de descentralização, o automóvel seria um dos responsáveis pela libertação da congestão metropolitana. Como parte importante do esquema regional, as rodovias deveriam ser planejadas para conectar as cidades da região em rede, de forma sistêmica. No entanto, do ponto de vista formal as estradas norte-americanas eram bastante criticadas. Benton MacKaye, preservacionista membro da RPAA, foi um dos primeiros críticos a elaborar conceitos acerca de uma nova rodovia segregada das demais atividades urbanas nos Estados Unidos. Em artigo publicado em 1930 - portanto anterior às autobahnen alemãs - MacKeye desenvolve o conceito de rodovias livres de cidade, as Townless Highways:

"mesmo nossas estradas mais modernas, modernas no sentido que possuem sólidas fundações e superfícies de concreto e superfícies adequadas nas curvas fechadas, elas são concebidas como meras extensões e alargamentos da velha estrada projetada para veículos de tração animal" 83 .

Além de terem sido construídas sobre antigos caminhos tortuosos, a cultura do automóvel em ascensão impactou negativamente a paisagem norte americana ${ }^{84}$. As estradas citadas por MacKaye estavam repletas de vendedores de comida, lojas, anúncios publicitários e estacionamentos, um resquício da cidade tradicional em expansão ao longo das rodovias. Esse conjunto de interferências às margens das estradas foi apelidado pelo autor como "motor slums," por conta da proximidade com a precariedade presente nas áreas pobres e degradadas da cidade industrial ${ }^{85}$. F. Scott Fitzgerald em seu famoso romance The Grat Gatsby, de 1925, remete a essa paisagem rodoviária que conectava Nova lorque aos ricos subúrbios de Long Island. Essas "terras desoladas ${ }^{86 " ~ f o r a m ~ a p e l i d a d a s ~ p e l o ~ e s c r i t o r ~ c o m o ~}$ "vale das cinzas":

"Uma fazenda fantástica onde as cinzas crescem como trigo em cumes e colinas e jardins grotescos; onde as cinzas tomam as formas de casas e chaminés e fumaça ascendente e, finalmente, com um esforço transcendente, de homens que se movem vagarosamente e já se desintegrando através do ar em pó. ${ }^{87 " \prime}$

Para que fosse possível romper com aquela forma de estrada seria necessária: "uma rodovia completamente livre de cavalos, carruagens, pedestres, cidade, cruzamentos em nível, uma rodovia construída para o motorista e mantida livre de todo tipo de ocupação, exceto postos de abastecimento e restaurantes necessários para a sua conveniência" ${ }^{88}$. Para isso, MacKaye propõe uma rodovia isolada, sem interferências. Sua visão combinava às necessidades técnicas da rodovia os aspectos paisagísticos, livrando-as de qualquer in-

83 "Even our most modern roads, modern in the sense that they have solid foundations and concrete surfaces and banks at the sharp turns, are conceived as mere extensions and widenings of the old-fashioned highway designed for horse-drawn vehicles." MCKAYE Apud SWIFT, 2011: p. 120.

84 FOSTER, 2003: p. 26.

85 SWIFT, 2011: p. 121.

86 "a certain desolate area of land."FITZGERALD, 1995 (1925): p. 16

87 "a fantastic farm where ashes grow like wheat into ridges and hills and grotesque gardens; where ashes take the forms of houses and chimneys and rising smoke and, finally, with a transcendent effort, of men who move dimly and already crumbling through the powdery air."FITZGERALD, 1995 (1925): p. 16

88 SWIFT, 2011: p. 121. 
terferência urbana, uma delicada inserção dentro da paisagem natural: "precisamos tomar posse das margens da rodovia, tornando-a livre de desenvolvimento comercial irregular e obtendo para o benefício do motorista as vistas agradáveis e aspecto de campo, puro do desordenado clamor dos anúncios publicitários" ${ }^{\prime 89}$. A proposta representa um salto conceitual em relação aos projetos de vias segregadas produzidos até então. Para Earl Swift, a visão de MacKaye apontava para a autoestrada contemporânea que conhecemos, tornando-o um dos pais da via expressa moderna ${ }^{90}$.

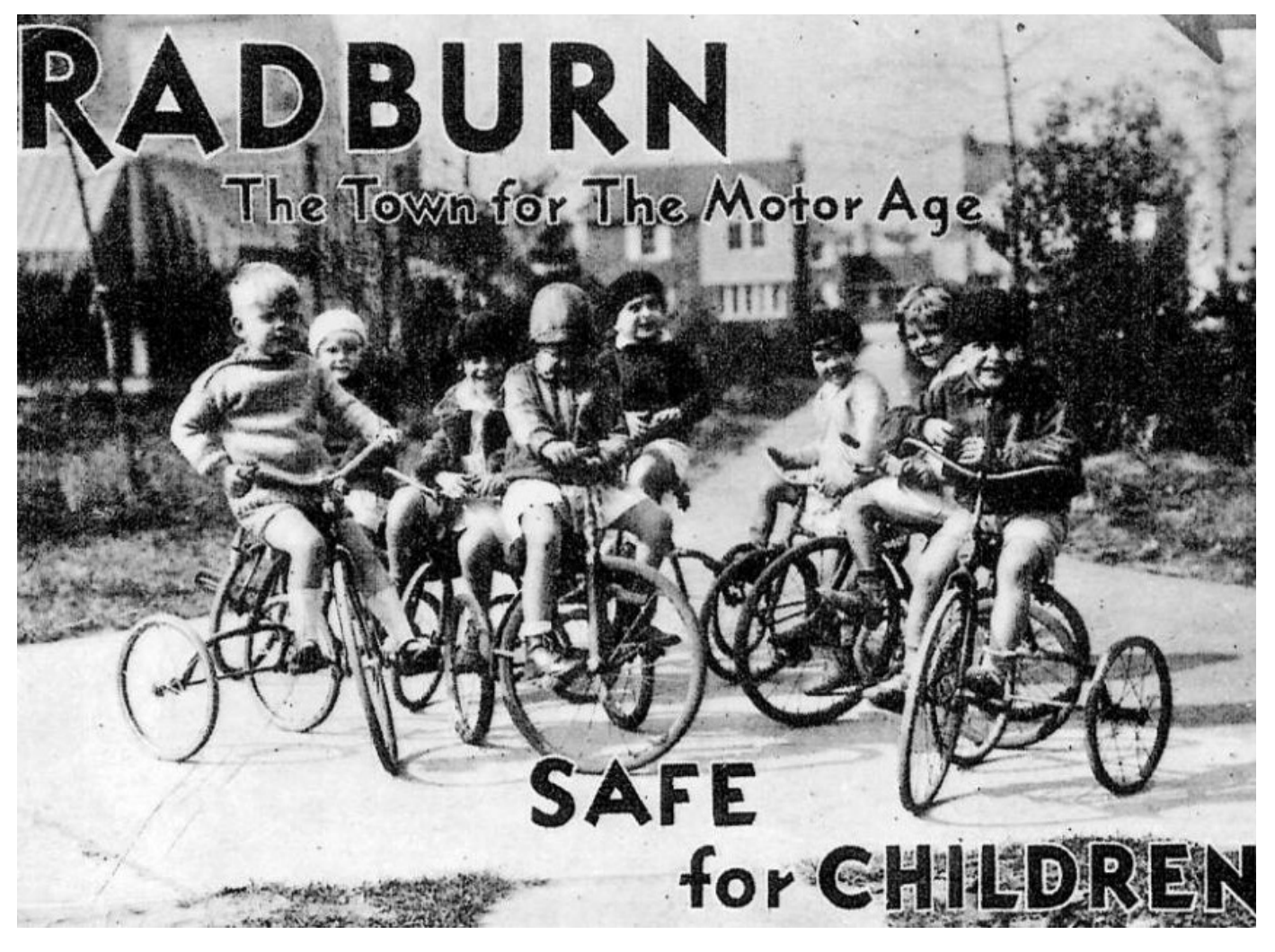

Figura 16 | Divulgação do empreendimento Radburn, sem data

No ano seguinte, MacKaye lança outra versão de seu artigo, dessa vez ao lado de seu companheiro Lewis Mumford. A dupla adiciona alguns princípios ao conceito das Townless Highways, afirmando que seria necessário garantir terreno suficiente às margens da rodovia de modo a isolá-la de seu entorno. O artigo deixa claro o interesse de transformação do espaço viário - de acordo com as premissas do urbanismo funcionalista -, adequando-o exclusivamente às demandas dos automóveis. Enquanto a estrada rural era local de encontro entre vizinhos, a autoestrada se resumia a um local de passagem:

"Nos dias do cavalo e da carroça a estrada serviu como companhia. (...) À medida que o carrinho ou a carruagem se movimentava, o fazendeiro

89 "a highway completely free of horses, carriages, pedestrians, town, grade crossings; a highway built for the motorist and kept free from every encroachment, except thefilling stations and restaurants necessary for his convenience." MCKAYE Apud. SWIFT, 2011: p. 121.

90 SWIFT, 2011: p. 122. 
no campo ou a dona de casa em seu alpendre podiam saudá-lo; O cavalo pararia quase por vontade própria, e a conversa fluiria. Mas uma vez que a estrada rural se torna uma estrada principal, cheia de tráfego rápido boa parte do dia e até mesmo da noite, quando os carros são dirigidos principalmente por estranhos, não vizinhos, toda a situação é alterada: a estrada deixa de ser um símbolo de sociabilidade; torna-se em grande parte uma maldição "91.

Complementando a rodovia sem cidade, o urbanismo da RPAA concebia também a cidade sem rodovia como forma de estruturação da sua "região metropolitana". O empreendimento Radburn, lançado em Nova Jersey, em 1929, era um balão de ensaio do que se imaginava como a "cidade para a era do motor" ${ }^{92}$, uma espécie de bairro regional onde o acesso do automóvel era controlado. Tal empreendimento se insere no New Deal de Roosevelt, que deu início a uma política de incentivo a construções habitacionais unifamiliares, financiadas pela Federal Housing Administration - FHA. Empréstimos eram concedidos para a crescente classe média norte-americana, que construía casas isoladas no terreno em loteamentos de baixa densidade no subúrbio ${ }^{93}$. A residência unifamiliar era o "sonho americano" e o governo estava disposto a realiza-lo, em uma medida que transformaria a paisagem norte-americana nas décadas seguintes. Concebido por Clarence Stein e Henry Wright, Radburn partia de uma estrutura de superquadras, para dispor residências unifamiliares em ruas sem saída, conectadas por uma via principal, remetente a um esquema "espinha de peixe". Nos fundos das casas, havia uma generosa área verde de uso comum, onde apenas pedestres seriam permitidos. Desse modo, segregavam-se o tráfego de automóveis, de acesso frontal, do pedestre que caminharia livremente pelas áreas verdes. Como observou uma publicação da época, "crianças indo e voltando da escola simplesmente deixariam suas casas pela porta do jardim, passariam através do caminho de pedestres e então adentrariam no parque até a escola, sem a necessidade de cruzar nenhuma rua de tráfego"94. Conforme afirma Swift, apesar de Radburn não ter inventado o bairro residencial de subúrbio, ou nem mesmo ter sido concebido como um, sua organização espacial com casas isoladas conectadas por ruas sem saída terminadas em cul-de-sacs inspirou posteriormente diversos empreendimentos semelhantes que copiaram sua forma de loteamento, sem, no entanto, manter as áreas verdes comuns. Tais áreas seriam transformadas em quintais, impossibilitando os passeios que conectassem o bairro na escala do pedestre. Para seus moradores, o automóvel se tornaria o único meio de transporte possível.

91 "In the days of the horse and buggy the high-road served as company. (...) As the cart or carriage joggled by, the farmer in the field or the housewife on her porch could hail it; the horse would stop almost on its own accord, and chat would flow. But once the country road becomes a main highway, filled with fast traffic a good part of the day and even of the night, when the cars themselves are driven mostly by strangers, not neighbors, the whole situation is changed: the road ceases to be a symbol of sociability; it becomes very largely a curse." Apud. SWIFT, 2011: p. 125.

92 "Town of the motor age." lbid.: p. 120.

93 CONN, 2014: p. 98-9.

94 "childern going to and from school will simply leave their homes by the Garden door, pass thorough to the pedestrian path and thus sits into the park to school without the necessity of crossing a single traffic street." Apud. SWIFT, 2011: p. 120. 


\section{BROADACRE CITY}

Broadacre City, de Frank L. Wright, é talvez a utopia urbana que mais próxima chegou dos princípios de "democracia agrária" jeffersonianos. Através da tecnologia do automóvel e da eletricidade, o arquiteto pretendia libertar homens e mulheres para que vivessem como indivíduos ao fundir cidade e campo, tornando-os agricultores-proprietários ${ }^{95}$. Wright começa a conceber o projeto em $1924^{96}$, apresentando-o pela primeira vez numa série de palestras em 1930. Posteriormente, seus conceitos se desenvolvem em três livros: The Disappearing City (1932), When Democracy Builds (1945) e The Living City (1958) ${ }^{97}$.

Anti-urbanista voraz, Wright afirmava que seria possível distinguir-se as boas cidades - orgânicas e naturais -, das más - não-orgânicas e não-naturais. No entanto, seu conceito de "orgânico" e "natural" estava ligado a natureza propriamente dita - e não a um crescimento urbano desordenado, como poderíamos pensar ${ }^{98}$. A esse crescimento desenfreado, o arquiteto tomaria emprestado de Jefferson a metáfora do câncer presente em seu famoso Notes on the State of Virginia. Segundo Wright, a tarefa da arquitetura "orgânica" era tratar o tecido urbano como um corpo tomado por um câncer, retirando as partes indesejadas para que pudesse ser possível a sua reconstrução: "olhar para a secção transversal de qualquer plano para uma grande cidade é olhar para algo como a secção de um tumor fibroso" ${ }^{99}$, dizia.

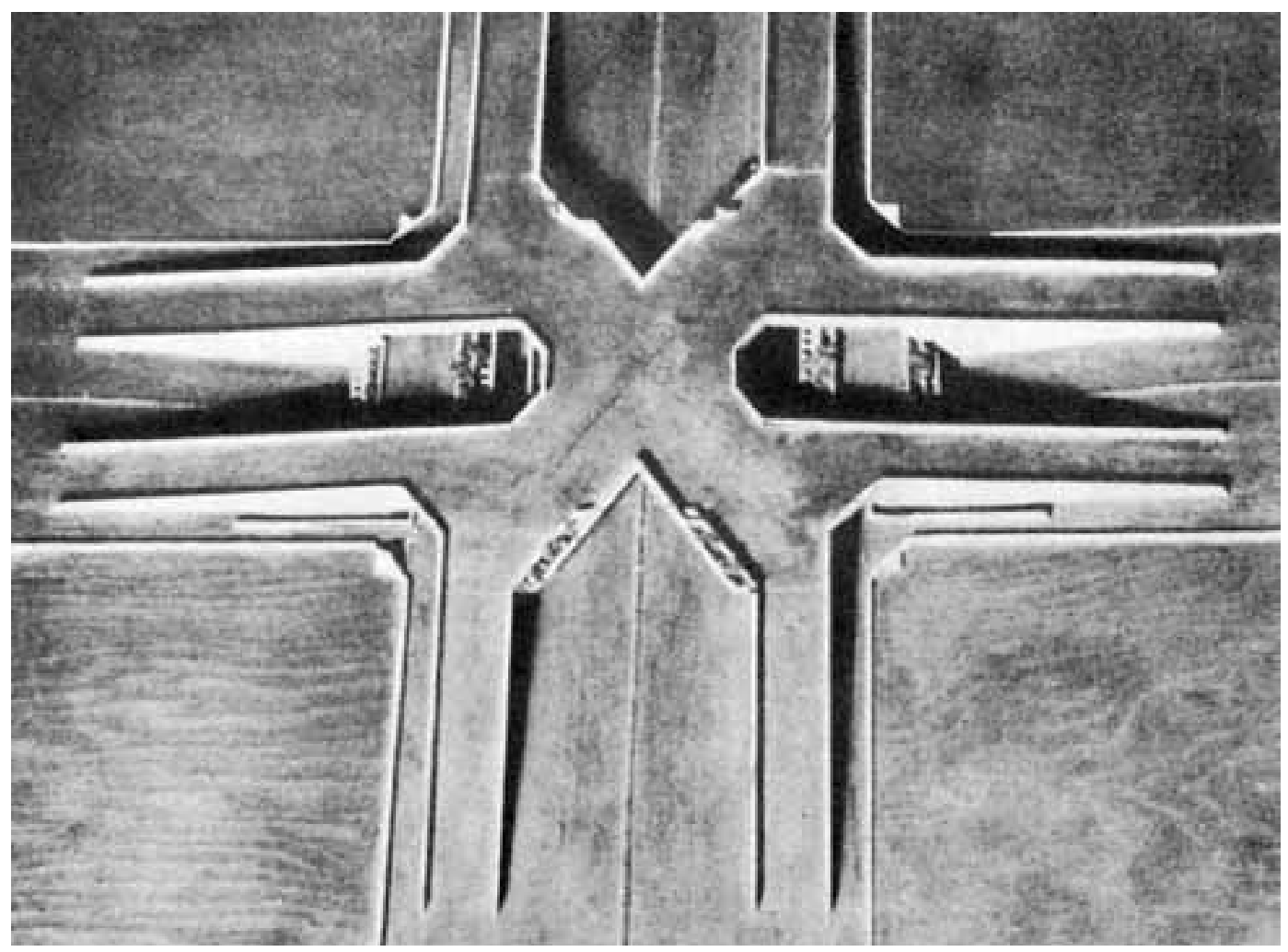

Figura 17 | Frank Lloyd Wright - Broadacre City: estudo para cruzamento rodoviário

95 HALL, 1988: p. 339-40

96 Ibid.: p. 339

97 SHELTON, 2010: p. 69.

98 WHITE; WHITE, 1962: p. 194.

99 "To look at the cross-section of any plan of a big city is to look at something like the section of a fibrous tumor."Apud. WHITE; WHITE, 1962: p. 193. 
Através da tecnologia - automóvel e avião, bem como meios de telecomunicação - Wright vislumbrava a possibilidade de uma verdadeira transformação social, onde a cidade tradicional não precisaria mais sequer existir. Broadacre City não propõe uma ambiência urbana inovadora, ou tampouco tenta criar uma nova forma de morar. Pelo contrário, a proposta pretende viabilizar a vida no campo que sempre existiu aliada às qualidades urbanas, facilitando o encontro entre pessoas através do automóvel e do telefone. Nas palavras de Peter Hall, a proposta "era a visão de sua Wisconsin da infância, resgatada através da nova tecnologia" ${ }^{100}$. A redução no tempo de deslocamento permitiria um afastamento entre cada assentamento, onde a escala do espaço seria ditada pelo automóvel. Nas palavras do autor: "a unidade fundamental de medição espacial mudou tão radicalmente que o homem agora se aglomera de dez para um e em velocidade de mil a partir do momento em que senta em seu automóvel. Esta circunstância tornaria a cidade obsoleta" ${ }^{101}$.

Ao invés de pensar a questão urbana, Wright pensa de modo mais amplo na ocupação do território nacional norte-americano. De acordo com Peter Rowe ${ }^{102}$, Broadacre City foi capaz de prever o desenvolvimento metropolitano descentralizado, de baixa densidade nas áreas rurais - especialmente nos Estados Unidos e na Europa. As rodovias seriam responsáveis pela organização do território. Desse modo, o arquiteto deveria ser transformado em um "mestre construtor de rodovias" ${ }^{103}$, possibilitando que a cidade se estruturasse ao seu redor:

"Imagine agora auto-estradas espaçosas, paisagisticamente tratadas, com as passagens de nível eliminadas por um novo tipo de sistema integrado de desvios ou de pistas rebaixadas ou elevadas que recebem todo o tráfego em áreas de cultivo ou moradia... (...) Essa distribuição integrada de vida relacionada com a terra compóe a grande cidade que vejo envolvendo este país. Essa seria a Broadacre City de amanhã, isto é, a nação. A democracia feita realidade" ${ }^{104}$.

Assim como no campo, em seu plano as distâncias são tão longas que não mais seria necessária a infraestrutura de circulação de pedestres. Nas descrições de 1932 eles não chegam sequer a ser mencionados ${ }^{105}$. Com a publicação de When Democracy Builds, Wright propõe seu próprio modelo de cruzamento rodoviário em desnível, incorporando quatro movimentos pedestres. Mesmo após décadas de desenvolvimento e provando seu funcionamento, os ângulos retos de sua proposta nunca se adequariam às necessidades de curvas em alta velocidade ${ }^{106}$.

100 HALL, 1988: p. 343

101 "The fundamental unit of space-measurement has so radically changed that the man now bulks ten to one and in speed a thousand to one as he seated in his motor car. This circumstance would render the city obsolete." WRIGHT, Apud. SHELTON, 2010: p. 70.

102 Apud. SHELTON, 2010: p. 70.

103 "master road builder."WRIGHT, Apud. SHELTON, 2010: p. 71.

104 WRIGHT, Apud. HALL, 1988: p. 342.

105 SHELTON, 2010: p. 71.

106 SWIFT, 2011: p. 71. 


\section{A MODERNIDADE PASTORAL DE LE CORBUSIER}

De modo a combater os problemas urbanos contemporâneos, Le Corbusier vislumbra ao longo da década de 1920 planos para uma nova cidade ideal, moderna, afastando-se das problemáticas da cidade tradicional. Sua visão urbana, posteriormente, se tornaria importante influência para o urbanismo desenvolvido, na segunda metade do século, no mundo todo. A repercussão de suas reflexões acerca do urbanismo moderno são resultado do viés profético de seu discurso, intencionalmente visionário, impregnado pela ideia de que para mudar as condições atuais é preciso um objetivo claro ${ }^{107}$, que transformasse a formulação do espaço urbano por completo. Seu primeiro plano, de 1922, para a "Cidade Contemporânea para Três Milhões de Habitantes", não parte de nenhuma especificidade geográfica ou cultural, pelo contrário, trata-se de "uma situação-modelo, universalmente adaptável" ${ }^{108}$, uma construção rigorosa, em busca da formulação dos princípios básicos do urbanismo moderno. Ao mesmo tempo, o urbanista se recusava a considerar seus planos como "utópicos". Ao invés de imaginar uma visão futura, o plano foi concebido para que funcionasse em sua época com o mais recente aparato tecnológico disponível. Pelo menos do ponto de vista técnico, a cidade poderia ser imediatamente realizável, de modo a servir como paradigma para projetos reais.

As questões relacionadas à circulação tinham papel fundamental em sua visão de cidade. Assim como os jovens futuristas, Le Corbusier se entusiasmou com as forças modernizadoras que transformam as cidades europeias naquele momento. Dentro dessa visão, o automóvel é considerado elemento fundamental e universal de nossa civilização, associado ao novo modo de vida moderno. Ele defende as máquinas e incita os 'senhores arquitetos' a abrirem os 'olhos que não veem' para navios, automóveis e aviões ${ }^{109}$. No plano para a "Cidade para Três Milhões de Habitantes" diferentes formas de circulação foram agrupadas no centro da cidade, segregadas em diversos extratos, explorando de forma radical os conceitos de verticalização das infraestruturas desenvolvido pelo engenheiro francês Eugène Hénard. Nos níveis mais baixos encontram-se as gares de trem nacional, sobrepostas pelos trens de subúrbio, seguidos pelo metrô e, por fim, a circulação de pedestres. Sobre eles, estariam dispostos os cruzamentos de automóveis em velocidade e acima de todos um aeroporto ${ }^{110}$.

Dentro da mais pura lógica funcionalista, a rua de sua nova cidade funcionaria como "uma máquina para circular, um aparelho circulatório, uma espécie de usina linear" ${ }^{111}$, onde suas vias de circulação partiriam dos princípios técnicos necessários ao automóvel. Com uma quantidade menor de ruas ${ }^{112}$, as quadras teriam quatrocentos metros de comprimento, ideais para os tempos de aceleração de um automóvel. 
De acordo com o Crítico Stanislaus Von Moos, velocidade e motorização são - para Le Corbusier - um fator do "lirismo dos novos tempos", uma obsessão no centro de toda a consideração urbanística, onde a nova velocidade não mais é coerente com as atividades humanas.

"As velocidades vinte vezes maiores $(100 \mathrm{~km} / \mathrm{h})$ substituíram a velocidade imemorial do passo do homem ou do passo do cavalo, ou do boi, do burro... Em cem anos, uma civilização nasceu, subvertendo tudo à sua paisagem. A medida humana foi transgredida, ultrapassada, talvez perdida"113.

"Na era do automóvel e do caminhão, os leitos de circulação exigem projetos em proporção. A velocidade simples do cavalo é substituída pela velocidade vinte ou trinta vezes maior da mecânica"114.

O urbanista defende a velocidade proporcionada pelo automóvel como elo fundamental de seus planos urbanos, tornado a infraestrutura rodoviária o principal elemento organizador da cidade moderna. Nas palavras de Le Corbusier, "uma cidade que é veloz é, também, uma cidade de sucesso" ${ }^{\prime 115}$. A paisagem da cidade moderna, com seus edifícios afastados uns dos outros, é melhor contemplada na velocidade do motor; é preciso uma máquina para se viver na cidade corbusiana. A linha reta em particular tem papel importante nos primeiros esquemas do urbanista. Ela é considerada - assim como para os futuristas ${ }^{116}-a$ característica formal do engenho humano ${ }^{117}$, representativa da ordem cartesiana, opondo-se às curvas da natureza. Para Von Moos, "o rigor do eixo constitui para Le Corbusier um princípio essencial, às vezes moral e estético", num discurso onde 'moral' e 'estética' estão intimamente ligados. Desse modo, podemos considerar o traçado da linha não apenas como elemento funcional, mas também simbólico e visual ${ }^{118}$ da cidade moderna. O caráter simbólico da linha reta é evidenciado em seu discurso:

"O trânsito exige a linha reta. A linha reta é sadia também para a alma das cidades. A linha curva é ruinosa, difícil e perigosa; ela paralisa."

"O homem anda em linha reta porque ele tem um objetivo; ele sabe onde vai."

"A ilha reta é o caminho do homem, a linha curva é do asno. O asno é símbolo da estupidez; é sobretudo o símbolo de um sistema de transportes urbanos que fez as ruas tortuosas da ldade Média."19

\footnotetext{
113 LE CORBUSIER, 1979: p.16.

114 Ibid.: p. 205.

115 LE CORBUSIER, em "O Urbanismo". Tradução livre a partir do original em francês: "La ville que dispose de la vitesse dispose du sucès" citado por MOOS, 1971: p. 146; assim como por CURTIS, 1992: p.63.

116 Apesar de diversas semelhanças entre o discurso futurista e corbusiano, de acordo com von Moos, Le Corbusier em nenhum momento faz menção ao trabalho de Marinetti e seus colegas (MOOS, 1971: p.146). No entanto, pode-se considerar improvável que o urbanista não tivesse conhecimento a respeito dessa produção sediada e divulgada em Paris na mesma época.

117 LE CORBUSIER, 1992: p.10

118 MOOS, 1971: p. 144-145.

119 "l'homme marche droit parce qu'il a un but; il sait où il va»; "la ligne droite est le chemin de l'homme, la ligne courbe celui de l'âne. L'âne, c'est le symbole de la stupidité; c'est surtout le symbole d'un système de transports urbains qui a fait les rues tortueuses di Moyen Age». LE CORBUSIER, Apud. MOOS, 1971: p.144-145.
} 


\section{VR}

12

CIRCIIATION

I.ES CROESEMENTS
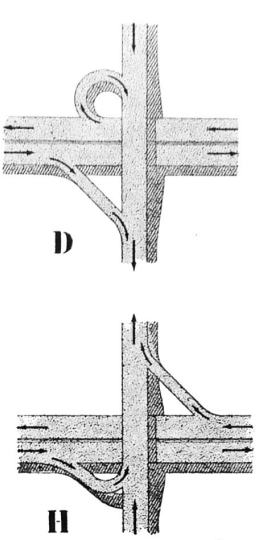
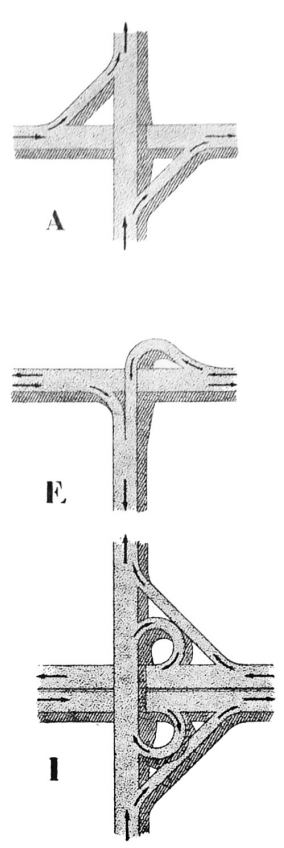
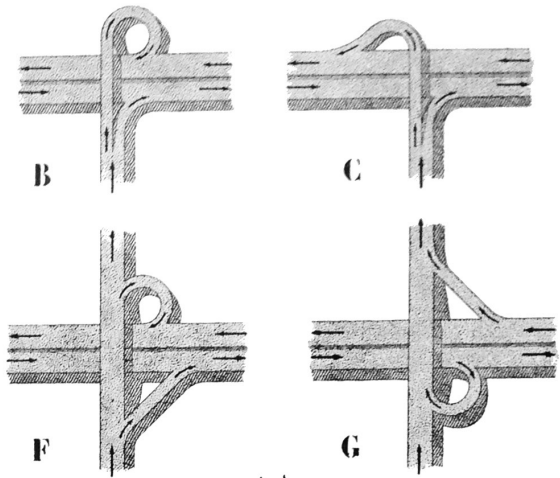

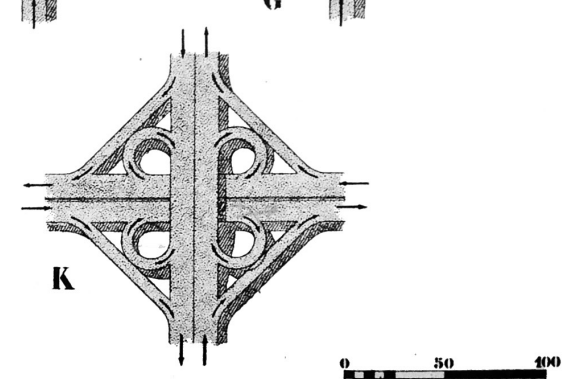

Figura 18 | Estudos de Encontros Viários para a Ville Radieuse

De acordo com o pesquisador Volker Ziegler, Le Corbusier sempre buscou para seus planos os mais novos dispositivos de circulação urbana, que viabilizasse o uso do automóvel nas cidades. Segundo o pesquisador, primeiramente, o arquiteto lança mão do termo autódrome (autódromo) para se referir às pistas de velocidade, presentes em seu primeiro projeto para a "Cidade Contemporânea", referindo-se a soluções que ele conhecera na década anterior ${ }^{120}$. Em 1910, Le Corbusier comparece a uma exposição em Berlim onde entra em contato com ideias acerca da circulação urbana. Por lá, ele encontra algumas das soluções que, de acordo com Ziegler, seriam recuperadas em seus projetos posteriores, como as "rotatórias" de Hénard, bem como exemplos de segregação de tráfego norte-americanos: "de tudo o que viu na exposição de Berlim, ele havia demonstrado um interesse especial pelas ruas que eram adaptadas às velocidades dos diferentes meios de transporte, mas que ficavam confinadas no seu próprio espaço" ${ }^{121}$. Desde então, o arquiteto manteve-se atento ao desenvolvimento tecnológico das vias de alta velocidade, sempre incorporando novos conceitos aos seus planos urbanos. Ziegler aponta em Le Corbusier o apoio de argumentos técnicos dos engenheiros de rodovia para justificar a construção de novas vias rápidas no lugar da "rua corredor" em seus planos urbanos. Nas palavras de Le Corbusier,

"as ruas não podem ser alargadas. E então? Então devemos procurar espaço acima ou abaixo." "A velocidade? Ela resume o próprio progresso de nossa sociedade moderna." "É essa a opinião que orientou os debates do Congresso Internacional de Rodovias (PIARC), realizado em Sevilha, em 1923"122 
Seus projetos posteriores, acompanhando os avanços tecnológicos da engenharia de rodovias, deixam o termo "autódromo" para adotar o conceito de "autoestrada", baseando-se nas primeiras experiências italianas. Em Ville Radieuse, do início da década de 1930, Le Corbusier passa a adotar soluções viárias tributárias do desenvolvimento tecnológico norte-americano. Nele, as vias expressas principais passam a não tolerar interferências entre fluxos distintos, conforme discutido no Congresso de Rodovias de 1930, realizado em Washington ${ }^{123}$. Cruzamentos em nível - permitidos antes entre as largas quadras da "Cidade para Três Milhões de Habitantes" - passariam a ocorrer apenas nas vias de acesso local.

Como Norte-Sul e Leste-Oeste constituem os dois eixos da cidade, as vias de travessia para a circulação rápida em mão única são estabelecidas sobre vastas passarelas de concreto de $40 \mathrm{~m}$ ou $60 \mathrm{~m}$ de largura ligadas a todos os 800 ou $1200 \mathrm{~m}$ por rampas ao nível das ruas normais. Atingem-se as vias de travessia num ponto qualquer de seu curso e pode-se alcançar o subúrbio nas velocidades mais rápidas, sem ter de aguentar nenhum cruzamento"124.

As cidades ideais corbusianas propõem uma forma distinta de uso do solo, onde grandes edifícios de alta densidade concentram toda a vida urbana moderna. As principais atividades - de habitação, comércio e serviço - estariam concentradas dentro de edifícios verticalizados. Seria, de acordo com o historiador José Ramón Alonso Pereira, uma "cidade-jardim vertical", cuja alta densidade permite a liberação do solo ${ }^{125}$ para atividades de características opostas à densidade dos edifícios. As áreas verdes têm papel importante na visão urbanística da cidade corbusiana. Nela, de 85 a 95\% do solo deveriam dar lugar a áreas verdes de recreação, tentando reestabelecer condições naturais no espaço urbano. Trata-se de uma nova visão se comparada a Sant'Elia ${ }^{126}$, distinguindo-se também do urbanismo alemão, de Ludwig Hilberseimer, onde as torres estão separadas por espaços reservados à circulação, evocando um deserto mineral ${ }^{127}$.

Referências a qualidades espaciais do campo são muito comuns na descrição dos espaços abertos da cidade funcionalista. A cidade futura rompe com os valores urbanos tradicionais para abarcar qualidades da natureza. $\mathrm{O}$ arquiteto se remete a memórias afetivas de seus anos de formação na paisagem campestre da cadeia de montanhas do Jura, na fronteira da Suíça com a França: "Recuo vinte anos, à minha juventude como estudante: a estrada então nos pertencia, cantávamos nela, discutíamos nela, enquanto cavalos e veículos passavam suavemente" ${ }^{\prime 28}$. De forma onírica, o urbanista descreve a paisagem bucólica que idealizou para a sua cidade: "estamos sob árvores. A grama nos envolve com imensas superfícies verdes. Ar puro. Sem barulho. Edifícios ainda não podem ser vistos. Através de galhos de árvores o céu é percebido" ${ }^{129}$. Em Ville Radieuse, o autor faz relação semelhante: 


\section{V li}

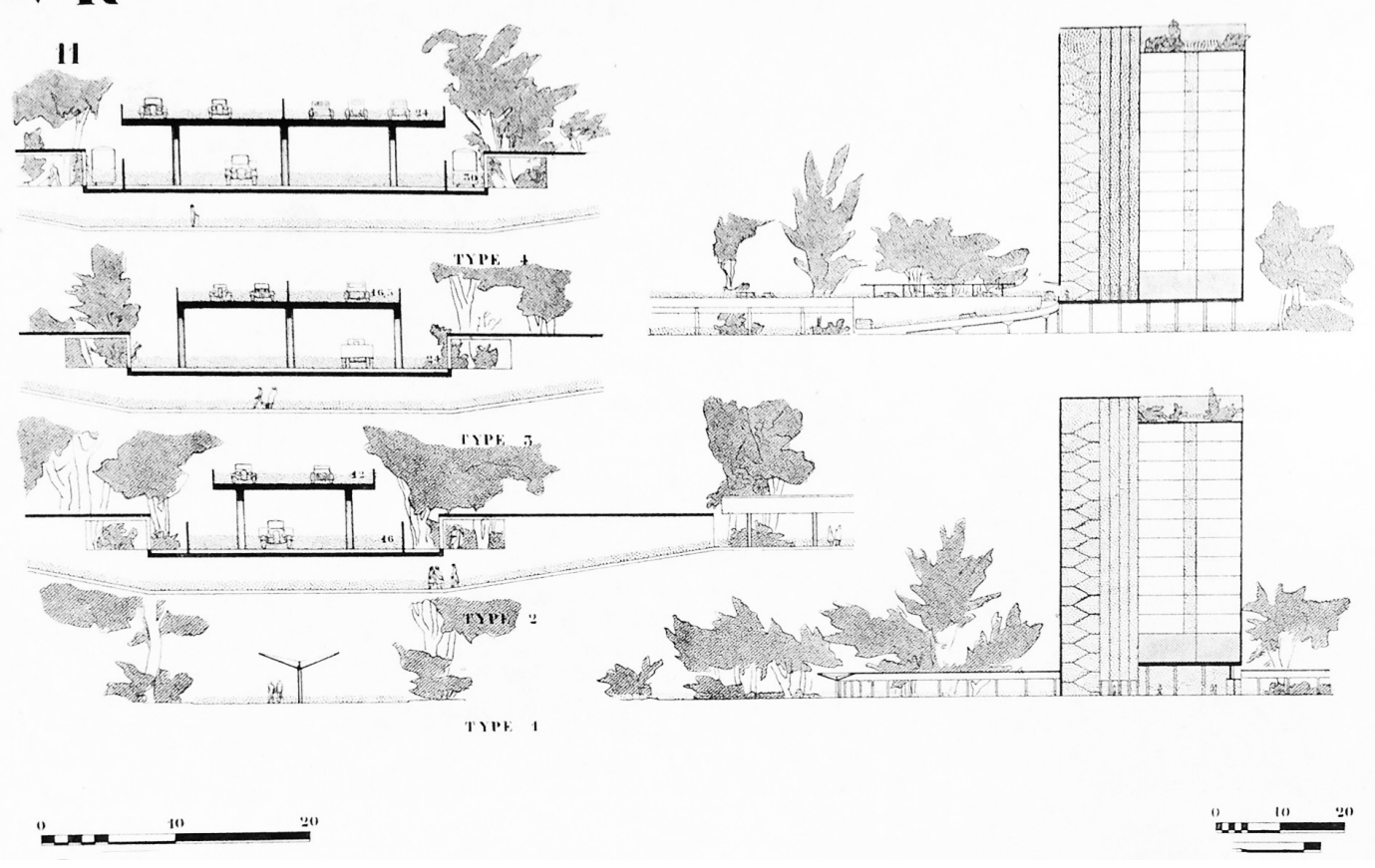

Figura 19 | Ville Radieuse-Cortes transversais, 1933

"Em 1922 eu comecei a entrar num sonho do qual não consigo sair: viver na cidade dos tempos modernos. (...) Eu criei novas dimensões, creio eu as alegrias essenciais: céu e árvores, parceiros de cada homem: sol em casa, azul nas janelas, um mar verde antes do amanhecer ${ }^{\prime \prime 130}$.

De fato, a cidade de Corbusier mistura em uma única visão ideais ligados à tradição clássica com a inventividade possibilitada pelos avanços tecnológicos ${ }^{131}$. Ao mesmo tempo, suas propostas pretendem conciliar no interior de uma grande cidade características de uma vida no campo. Como observa Berman, seu urbanismo aponta para uma cidade onde "modernismo e bucolismo podiam se entrelaçar" ${ }^{132}$. Von Moos vê nesse modelo bucólico referência à "cidade industrial", de Tony Garnier, onde as áreas verdes têm um papel muito importante. Le Corbusier também apreciava os grandes jardins parisienses haussmannianos ${ }^{133}$, dispostos em sistemas de áreas verdes que interagiam diretamente com os sistemas de circulação, referindo-se a essas áreas - assim como fizera Haussmann - como pulmão da cidade. Contudo, na obra corbusiana, seu significado se estende a um papel psicológico. Com uma proporção muito maior de áreas verdes em relação à área construída, o modelo urbanístico de Le Corbusier inverte a relação figura-fundo da cidade tradicional, através da qual se cria uma vista que se estenda ao longe, tornando possível a apreciação do horizonte no interior da cidade ${ }^{134}$. Para von Moos, o urbanista perde de vista seu 
argumento - onde defende a restauração das condições naturais -, pois enquanto a vegetação se espalha, o cinza urbano faz com que ele pareça um reles "tapete decorativo": "A natureza aparece sob a forma grandiosa (mas nulamente vital) das longas perspectivas, do espaço infinito" ${ }^{135}$.
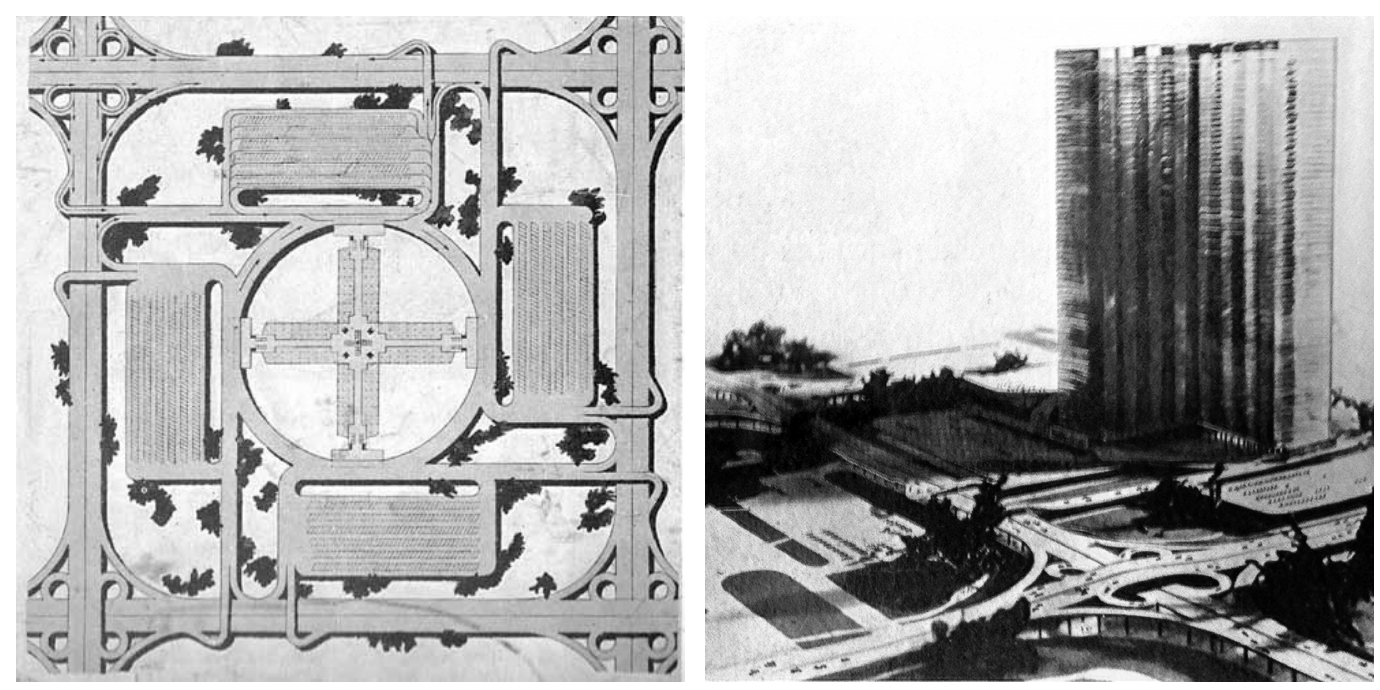

Figura 20 | Le Corbusier - Ville Radieuse, 1933

As áreas verdes do plano de Le Corbusier seriam destinadas ao pedestre. Separadas das vias expressas, as amplas áreas averdejadas restariam livres para demais atividades. Parecia ser uma troca justa, afinal, alienado do espaço da rua, o homem a pé teria direito a uma grande parte da superfície, tão diferente do degradado ambiente urbano da grande cidade. O urbanista descreve uma situação hipotética, em um futuro próximo onde Paris seria 'moderna':

PARIS, VERÃO, 1942: "As ruas não têm mais carros, o silêncio paira sobre a cidade, o ar é puro, junho ilumina essa vitória sob o céu de Île-de France: o pedestre é rei (...). A dignidade do pedestre restaurada permitiu aos homens olhar sua cidade. Dela se lembrarão, mais tarde, aqueles que aí viveram" ${ }^{136}$.

No entanto, conforme Le Corbusier absorve o desenvolvimento tecnológico rodoviário em suas propostas, o espaço verde livre se reduz cada vez mais. Nota-se na proposta para a Ville Radieuse que rampas, alças de acesso e estacionamentos passam a ocupar muito mais espaços livres nos terrenos do que os próprios edifícios. Na tentativa de manter o térreo livre de usos específicos, a rodovia também ganha pilotis. Para o urbanista, ao elevá-la, o solo da cidade continuaria livre para o desfrute do homem. Perguntado sobre sua escolha ao segregar o tráfego, elevando os automóveis ao invés das pessoas - como fizeram outros, como Corbett e Hilberseimer - o urbanista responde dura e ironicamente: 
"Eu apelo aos nossos PADRÕES humanos para nos resgatar de uma sugestão como essa! Deveria o homem passar sua vida a partir de agora gesticulando pelos ares em uma série de plataformas (inevitavelmente) estreitas, subindo e descendo escadarias - um macaco no topo das árvores! Se o homem possuísse os ágeis pés e o rabo milagroso de um macaco talvez fizesse sentido. Mas na verdade é loucura. Loucura, loucura, loucura."137

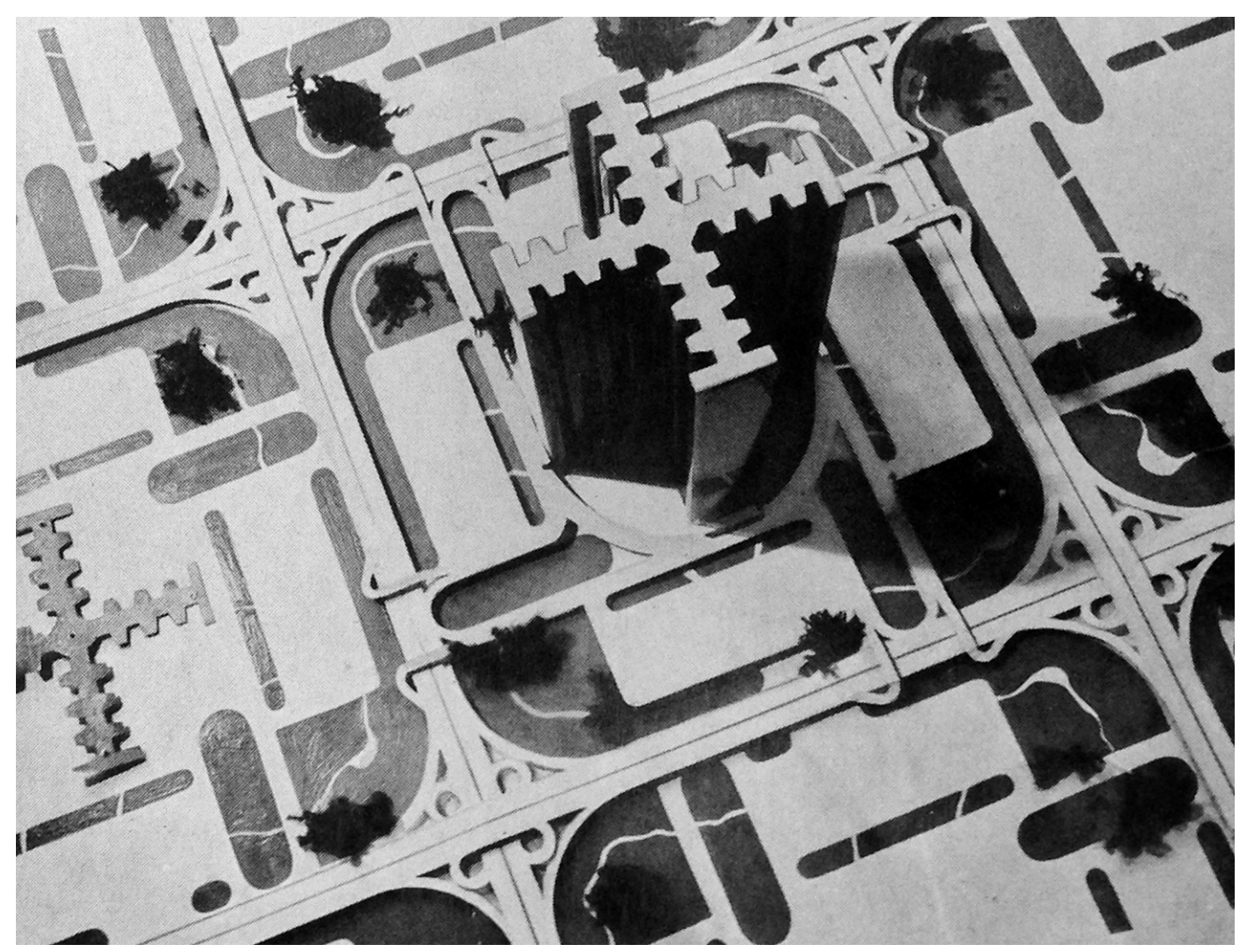

Figura 21 | Le Corbusier - Ville Radieuse, 1933

No entanto, aprendemos hoje a duras penas que como resultado dessa operação obtemos apenas não-lugares. Espaços verdes entre rodovias acabam se tornando meros espaços residuais, ou apenas contemplativos. A via elevada tampouco agrega qualidades ao espaço que ela cobre. Pelo contrário, a falta de iluminação natural aliada ao ruído torna esses espaços desagradáveis. Para Berman, ao conceber a cidade moderna para o automóvel, Le Corbusier passa a se identificar com as forças que o pressionam na cidade tradicional ${ }^{138}$. Em nome da defesa do que é 'moderno', ele está disposto a romper com os valores urbanos. "O homem moderno de Le Corbusier fará um movimento gigantesco, que tornará desnecessários os movimentos seguintes, um grande salto que será o último. O homem na rua se incorporará ao novo poder tornando-se o homem no carro"139. 


\subsection{AS PARKWAYS DE NOVA IORQUE: SÍNTESE DA RODOVIA ANTIURBANA}

Diferentemente das demais metrópoles norte-americanas, Nova lorque, através de seu interventor Robert Moses, foi capaz de implementar projetos de vias expressas em larga escala ${ }^{140}$. Quatrocentos e oitenta quilômetros de vias foram construídos nos arredores da cidade antes do início da Segunda Guerra Mundial. Tamanha intervenção só fora possível graças às habilidades de Moses, que conhecia os caminhos burocráticos necessários para colocar seus projetos em prática, sendo talvez um dos primeiros a compreender o compromisso da administração Roosevelt, através do New Deal, com as obras públicas, que ajudariam a reerguer a economia norte-americana da crise. Num processo que se estenderia por mais de quarenta anos, Moses foi - nas palavras de Berman - capaz de personificar a visão do moderno através de diversas de suas intervenções na região metropolitana de Nova lorque ${ }^{141}$.

Desde a década de 1920, Moses desenvolveu diversos projetos de vias arteriais, associadas a parques e equipamentos públicos de lazer. Como presidente da Long Island State Park Commission, ele foi capaz de encampar empreendimentos rodoviários integrados à construção de parques públicos. Sua primeira visão nesse sentido, segundo seu biógrafo Robert Caro, pretendia transformar Jones Beach, um local de difícil acesso, em um grande balneário. Para torná-lo acessível, seria necessário construir uma estrada que atravessasse toda Long Island, penetrando sua bela paisagem natural, que o urbanista conhecia de suas incursões na região. Assim como nas primeiras parkways do século anterior, Moses pretendia integrar à paisagem rodovias, em um desenho único, como num parque linear, fazendo com que o motorista já chegasse ao parque logo no início de sua jornada ${ }^{142}$. A Bronx River Parkway - primeira parkway para automóveis que, naquele momento, ainda não havia sido inaugurada - era sua grande referência de projeto. Diziam os jornais da época que seria a mais bela estrada da América, mas a estrada que Moses imaginava seria - para seu autor - ainda mais bela ${ }^{143}$. Conforme suas demais ambições começavam a se concretizar, seus planos para Long Island se tornavam cada vez maiores: Moses pretendia construir na região quarenta acres de parques e duzentos quilômetros de vias.

\footnotetext{
140 "in conjunction with the pump-priming initiatives of the New Deal, the 1930s would offer the first opportunities for significant urban freeway construction. President Franklin D. Roosevelt's programs of federally funded public works enabled Robert Moses, the country's premier public entrepreneur, to take his urban projects off the drawing board and into the city." DIMENTO; ELLIS, 2014: p. 23.

141 BERMAN, 1986: p. 279.

142 "he wanted the parkways to be broader and more beautiful than any roads the world had ever seen, landscaped as private parks are landscaped so that they would be in themselves parks, 'ribbon parks', so that even as people drove to parks, they would be driving through parks" Ibid.: p. 172.

143 CARO, 1975: p. 163.
} 
Posteriormente, suas ambições extrapolaram os limites de Long Island. Moses lança, em 1930, um grande plano para a construção de um sistema de parques, bulevares e pontes, conectando a região central da cidade com seu entorno. O plano desenhava um sistema de características radio-concêntricas tendo Manhattan como epicentro. Essas vias arteriais foram concebidas na mesma forma de parkways, com intensa vegetação em suas bordas, como uma forma de penetrar com a paisagem natural dentro do tecido urbano existente $^{144}$. Suas ideias tiveram grande aceitação perante a opinião pública, com grande apoio de motoristas sedentos por mais ruas. No entanto - como lembra Berman - as parkways foram utilizadas como "biombo social", o uso de suas pistas era exclusivo dos automóveis individuais, tornando-as acessíveis apenas a seus proprietários:

"Suas alamedas somente podiam ser experimentadas de automóvel: as passagens de nível foram propositalmente construídas numa altura que obrigava os ônibus a abandoná-las, de modo que o trânsito público não pudesse trazer as massas da cidade à praia. (...). Para a grande maioria dos nova-iorquinos, no entanto, seu verde e novo mundo nada mais oferecia além de um sinal vermelho"145.

Assim, colocava-se pela primeira vez, diante o espaço público, a antipatia automobilística, isolando o homem no volante dos demais.

A via expressa mais emblemática desse período é a Henry Hudson Parkway. Construída ao longo da costa oeste de Manhattan em direção ao norte, ela atravessa em comprimento um extenso parque linear com diversos equipamentos públicos, como quadras de tênis, passeios e brinquedos para crianças. Contudo, conforme observou Robert Caro ${ }^{146}$, a parkway impossibilitou por completo o contato dos pedestres no parque com as margens do Rio Hudson.

O crítico suíço Siegfried Giedion, grande entusiasta do urbanismo moderno, já exaltava as parkways nova-iorquinas em seu livro "Space, Time and Architecture,"- publicado pela primeira vez em 1941 - como elemento rodoviário do futuro. Apesar de ressaltar que não se tratavam exatamente de uma novidade ${ }^{147}$, o autor enxergava nessas vias elementos característicos do urbanismo funcionalista corbusiano, por ele apoiado com grande entusiasmo:

"Como um elemento da cidade futura, a 'parkway' restaurou os direitos tanto da circulação de veículos quanto da de pedestres; harmonizou o funcionamento de ambos os domínios, ao separá-los definitivamente um do outro, e conferiu plena liberdade a ambos ${ }^{\prime 148}$.

\footnotetext{
144 DIMENTO; ELLIS, 2014: p. 36.

145 BERMAN, 1986: p.283.

146 Apud. DIMENTO; ELLIS, 2014: p. 38-9.

147 De acordo com o autor, "o cinturão verde por meio do qual Haussmann pretendia circundar Paris e ligar o Bois de Boulogne e o Bois de Vincennes, os boulevards que ligavam os sistemas de parques do sul em Chicago no começo dos anos 1890, a configuração de estradas semelhantes a parques em Minneapolis pelo professor Cleveland em 1883 - todos estes pertenciam à categoria de vias parque. O recurso ao cruzamento viário em dois níveis, a fim de melhorar o fluxo de tráfego, geralmente aplicado a ferrovias e mesmo a ruas com excesso de cruzamentos, era uma prática difundida no século XIX". (GIEDION, 2004: p. 847.)

148 Ibid.: p. 847.
} 
Giedion dá grande destaque ao seu desenho, que seguia o curso da topografia, dos rios, misturando-se à paisagem natural - conforme o modelo urbano modernista. O crítico também dava grande destaque ao tratamento paisagístico das suas margens, com canteiros centrais que se alargavam e estreitavam ao longo do percurso ${ }^{149}$. Como nota muito bem o autor, esses caprichos de desenho estavam estreitamente relacionados a experiência do dirigir:

"somente quando se dirigia um automóvel era possível saber o que las parkways] significavam - a libertação dos semáforos e cruzamentos inesperados e a liberdade de movimento contínuo, sem a pressão desumana das retas intermináveis impelindo-nos a velocidades perigosas. Como muitas de outras obras oriundas do espírito da nossa época, o significado e a beleza das parkways não podem ser apreendidos a partir de um único ponto de vista, como era possível no Palácio de Versalhes, onde, a partir de uma única janela, toda a extensão da natureza podia ser abarcada com um só olhar. A parkway só pode ser apreendida em movimento, quando se segue o fluxo contínuo determinado pelas regras de trânsito. A concepção de espaço-tempo de nossa época raramente pode ser percebida de modo tão agudo como ao volante de um automóvel subindo e descendo colinas, passando sob viadutos, sobre rampas e pontes gigantes" 150

O crítico também destaca a importância do trabalho dos engenheiros em viabilizar as primeiras construções que se adequassem às necessidades automobilísticas:

"Os engenheiros frequentemente estavam mais próximos dos desenvolvimentos futuros do que os urbanistas, que muitas vezes estiveram mais preocupados com a reorganização da estrutura urbana (...). As parkways americanas, tal como se desenvolveram em torno de 1920-30 - (...) apresentavam-se como um dos elementos da cidade contemporânea decorrentes da visão que temos do nosso tempo"151.

No entanto, apesar de Giedion relacionar as parkways de Moses com o urbanismo modernista, Volker Ziegler nos mostra como seu traçado sinuoso e adepto a maneirismos era criticado por Le Corbusier. Para o urbanista europeu - assim como podemos notar nas autobahnen alemãs - o traçado rodoviário precisava servir ao automóvel e, desse modo, deveria ser mais objetivo; ao invés de pretender se misturar à natureza, a rodovia deveria se contrapor à complexidade da paisagem natural através da racionalidade de seu desenho. Ziegler descreve essa opinião:

“Em 1937 ele critica as parkways da região nova-iorquina. Imaginando que sua "rede sinuosa, sedutora, pitoresca - um pouco melhorada cobriria todo

149 CABRAL (2006, p.60) destaca aspectos semelhantes na Europa durante o mesmo período, citando o desenho das autobahns alemãs: "projetadas por equipes multidisciplinares, constituídas tanto por engenheiros como por paisagistas e urbanistas, evocando um "design total" do werkbund, enfatizando a adequação entre as vias e o entorno, proporcionando vistas aos viajantes e uma integração "cênica", romântica e culturalista. Eram sinuosas não apenas por adequação topográfica, mas por um princípio estético organicista, sendo suas pontes e viadutos concebidos como monumentalidade evocativa".

150 GIEDION, 2004: p. 848-849

151 Ibid.: p.846 
o território dos Estados Unidos, ele defende as estradas francesas, com seus traçados retos, indiferentes às colinas e aos vales, que o automóvel vence brincando, de tanto que esses trajetos parecem ter sido concebidos especialmente para ele." A missão heroica da estrada é, portanto, sempre a de circulação, enquanto a "pastoral" é ainda associada ao lazer" 152.

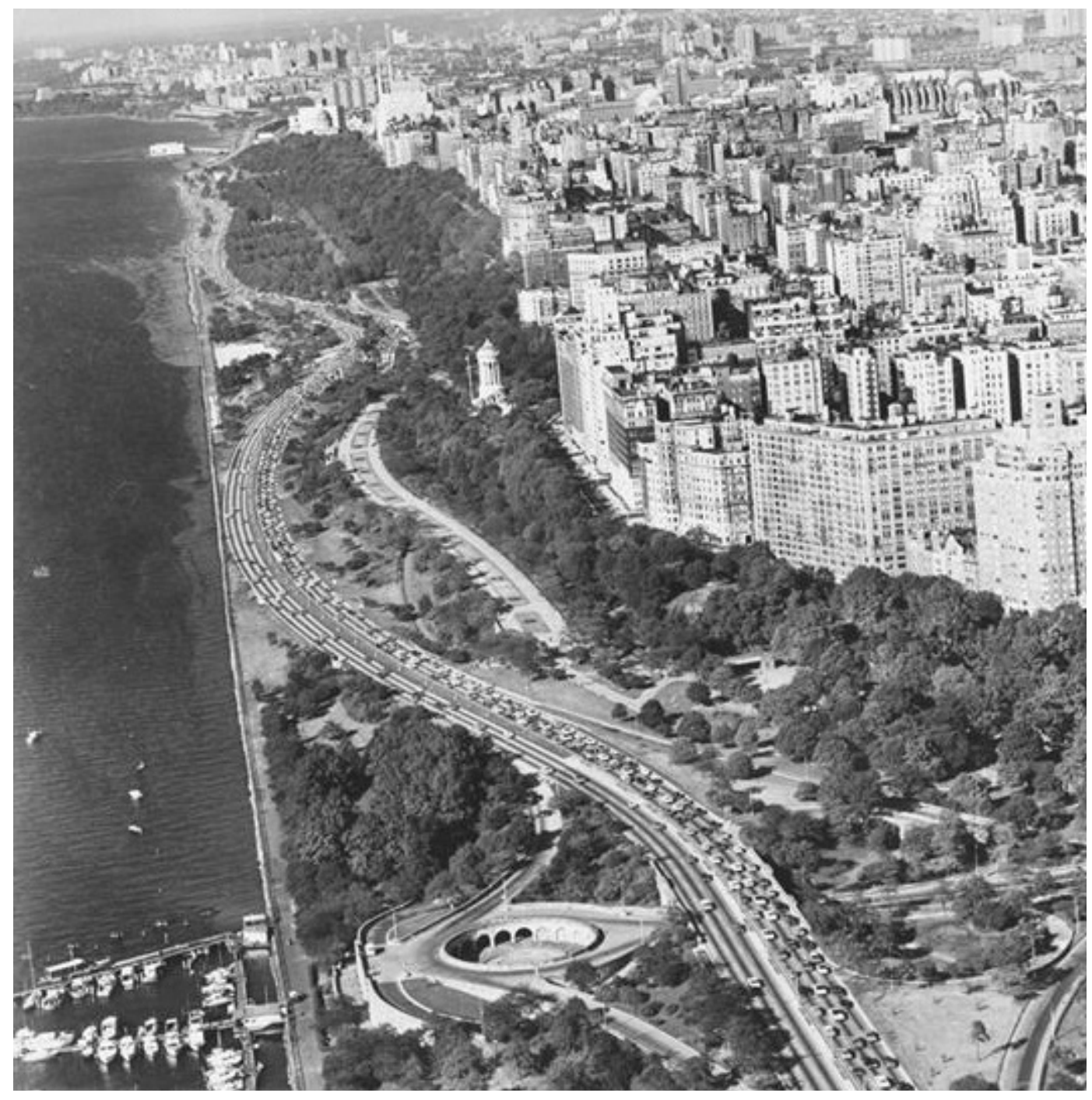

Figura 22 | Henry Hudson Parkway

Por fim, Giedion aclama mais uma vez o caráter inovador dessas estruturas, representadas pela Henry Hudson Parkway, ao afirmar que "esta grande parkway periférica, com seus vários centros recreativos e vias de acesso, prenuncia a nova escala da cidade ${ }^{\prime 153}$. No entanto, em busca de um novo urbanismo para o Século XX, o crítico afirma que a construção das novas vias nos arredores da cidade, negando a cidade tradicional, não eram suficientes. Para ele, para resolver os verdadeiros problemas da cidade seria necessário enfrentá-la: 
"Porém, o problema da cidade em si mal foi tocado. Naquela época a parkway terminava onde o corpo maciço da cidade começava. Não era capaz de penetrar a cidade, pois esta permanecia uma estrutura inflexível, estreitamente fechada e imóvel. A parkway não é uma via de tráfego independente do organismo da cidade. Simplesmente tem uma escala diferente daquela da cidade existente, com suas 'rues corridors' e sua divisão rígida em pequenos blocos. Melhorias nos acessos à cidade pouco podem fazer. É a estrutura da cidade que tem de ser mudada"154.

"A parkway foi a precursora da via expressa urbana, a qual, se apropriadamente projetada e adequadamente implantada, poderá incorporar o automóvel e as linhas de tráfego ao organismo da cidade, de modo que sejam um elemento constituinte do todo. A via expressa poderá atravessar a cidade como as primeiras parkways atravessavam a paisagem, tão flexíveis e livres quanto a própria planta da casa americana ${ }^{\prime \prime 155}$.

Nas palavras de Giedion vemos uma espécie de premonição que atingiria não apenas Nova lorque, mas tantas outras cidades ao redor muno nas décadas seguintes, quando finalmente as vias expressas enfrentariam as cidades, penetrando em seu interior em direção ao centro. No precursor caso de Nova lorque, Moses tornou-se cada vez mais poderoso, tornando-se, posteriormente, um dos grandes responsáveis pelas principais transformações no espaço público após a Segunda Guerra Mundial, através de suas Expressways urbanas. 



\section{III// 3. \\ A RODOVIA \\ ENFRENTANDO A CIDADE}

"A cidade do amanhã será uma cidade automotiva"

Miller McClintock, 1937

"As rodovias rurais podem contribuir muito com o alívio das ruas das cidades"

Alvan Macauley, 1929 



\subsection{A CIRCULAÇÃO NA CIDADE INDUSTRIAL}

A revolução industrial transformou as relações do homem com a cidade, influenciando diretamente as questões de deslocamento. Em busca de emprego nas fábricas, grandes contingentes populacionais deixaram o campo em direção às cidades. Aquelas sem limites claros espraiaram, criando novas áreas urbanas periféricas - muitas vezes sem infraestrutura adequada - aumentando as distâncias dos deslocamentos urbanos. Nas antigas concentrações urbanas muradas a população se amontoava, tornando-as cada vez mais densas, insalubres e difíceis de circular.

Nesse período, transformam-se também as relações com a terra urbana. A reboque da ascensão da classe burguesa ao poder, criam-se as bases sociais e jurídicas para a posse privada da terra, possibilitando o estabelecimento do mercado imobiliário. Ele funciona como importante forma de acumulação de capital e especulação ${ }^{1}$, sem o menor controle por parte do Estado ${ }^{2}$. Ao transformar a propriedade de terra urbana em mercadoria, o capital rompe com a ordem tradicional da cidade medieval, antes organizada em bairros autônomos $^{3}$, onde coabitavam "pobres, burgueses abastados e seus servos" ${ }^{4}$, muitas vezes em um mesmo imóvel.

Tais transformações na densidade e mancha urbana das cidades, bem como nas relações de posse e ocupação de imóveis urbanos, modificam o espaço da cidade. Primeiramente, bairros inteiros se especializam ${ }^{5}$ em certas atividades, excluindo outros acontecimentos urbanos de seus arredores; os centros urbanos concentram as atividades comerciais principais; os locais de moradia da população urbana passam a segregar-se de acordo com o poder aquisitivo dos moradores. No caso de Paris, por exemplo, enquanto os mais ricos se concentraram no lado oeste da cidade, as indústrias se concentraram na parte leste, atraindo um grande contingente da população operária para os seus arredores. ${ }^{6}$

Um dos elementos principais de regulação de preços do mercado imobiliário é a localização de um terreno em relação ao centro principal da cidade, este definido como local

1 SAKAGUCHI descreve o caso do 'Código de Direito Civil Napoleônico' na França, utilizado aqui como exemplo para operações em outros contextos semelhantes. (SAKAGUCHI, 1998: p. 142)

2 SAKAGUCHI cita Paolo Sica: "a ausência total de qualquer controle expresso sobre o processo social de produção: liberdade no uso e no desfrute de capitais, da propriedade e do trabalho, liberdade no uso e no desfrute do espaço urbano e territorial, que é o suporte da produção (...) se pede que o Estado desempenhe um papel técnico-administrativo de tutor do interesse público, que sirva, por um lado, para regular os conflitos entre as classes sociais [manutenção da ordem] e, por outro, para desempenhar toda uma série de funções de interesse coletivo". (Ibid.: p. 142)

3 CHOAY, 2000: p.13

4 SAKAGUCHI, 1998: p. 143.

5 CHOAY, 1965: p. 4

6 Loc. Cit. 
onde ocorrem suas atividades principais ${ }^{7}$. A lógica de especulação determina que o preço de um imóvel será maior quanto mais próximo ele for desse centro. Consequentemente, na mesma medida que a classe burguesa vive em regiões mais bem localizadas e acessíveis, a população pobre se distancia cada vez mais das áreas centrais, diminuindo assim sua capacidade de mobilidade ${ }^{8}$.

Edmond About afirma sobre a Paris de 1867: "a impaciência universal estima nos mais altos preços as moradias mais facilmente acessíveis, aquelas que são, como se diz, próximas de tudo..." ${ }^{9}$, demonstrando como a "impaciência universal" - resultado dessa nova relação do homem com o tempo - transforma em bem valioso a localização de um imóvel de acordo com a sua posição no espaço urbano. Isso ocorre porque a nova configuração espacial da cidade tornou deslocamentos urbanos rotineiros em tarefas cada vez mais difíceis e cada vez mais esses trajetos passaram a ser muito longos e demorados para serem feitos a pé.

Em particular, a separação entre local de trabalho e moradia da população pobre passou a ser um entrave produtivo importante para o capital. Era preciso que os rápidos deslocamentos, antes privilégio dos ricos ou daqueles que podiam custear animais, se tornassem mais acessíveis. Soluções como a "carrosse de pauvre'" parisiense, que carregavam grupos de 15 indivíduos ou mais por viagem, surgiam para ligar o centro da cidade à periferia, levando parte da população proletária ao seu local de trabalho ${ }^{10}$. Esses meios de transporte foram embriões do que se tornaria, não muito mais tarde, uma rede de transporte coletivo, elemento fundamental dentro da lógica de distribuição espacial da cidade industrial ${ }^{11}$.

Todas essas pressões sobre o espaço urbano, aliadas a importantes necessidades de aumento de produtividade impostas pelo capital fazem absolutamente necessária uma maior eficiência dos deslocamentos urbanos, demandando transformações radicais no espaço das cidades tradicionais. Para a cidade industrial, a velocidade de deslocamento dos homens não é suficiente e a cidade pré-industrial - das ruas estreitas e dos deslocamentos a pé - se torna um entrave. A solução encontrada para resolver essa questão envolvia a abertura de novas vias de circulação, rápidas e eficientes, sobre a cidade existente. A rodovia precisava enfrentar a cidade em busca de eficiência, permitindo o aumento da produtividade.

\section{O SISTEMA VIÁRIO URBANO ANTES DO AUTOMÓVEL}

A partir do momento que a circulação urbana se tornou um problema, drásticas transformações no espaço urbano foram necessárias para tornar a circulação urbana mais eficiente. Nesse contexto, as intervenções sobre o tecido urbano da Paris pré-revolucionária, durante a

7 VILLAÇA, 1998.

8 "(...) a cidade lugar de trocas, da circulação (...) não tolera mais a fragmentação, herança de um crescimento por adição. (...) Assim, o valor da cidade reside na mobilidade das pessoas e dos bens e esta mobilidade deve atender aos valores imobiliários, ligados, em suma, na representação que se faz dos valores mobiliários. Circulação e especulação estão associados nesta nova imagem da cidade importante." RONCAYOLO Apud. SAKAGUCHI, 1998: p. 144.

9 SAKAGUCHI, 1998: p. 165.

10 Os primeiros serviços de transporte da França já haviam surgido no início do século XVII. No entanto a sua difusão só virá a ocorrer na cidade industrial no início do século XIX. SAKAGUCHI, 1998: p. 145.

11 "pela primeira vez em sua história, Paris excede a escala do trajeto pedestre: a ligação é evidente entre a abertura dos primeiros loteamentos para fora dos muros, a partir de 1824 e o nascimento do ônibus quatro anos mais tarde". LOYER Apud. SAKAGUCHI, 1998: p.145. 
segunda metade do século XIX, transformaram a cidade no primeiro grande modelo urbano construído da era burguesa. Com caráter modernizador, intervenções "cirúrgicas" foram radicalmente realizadas no tecido urbano da cidade existente, sanando diversos problemas urbanos através da construção de novas vias de circulação ${ }^{12}$. O bulevar parisiense seria o grande símbolo desse novo urbanismo, considerado por Marshall Berman "a mais espetacular inovação urbana do século XIX, decisivo do ponto de partida para a modernização da cidade tradicional", que "permitiu ao tráfego fluir pelo centro da cidade e mover-se em linha reta, de um extremo a outro - um empreendimento quixotesco e virtualmente inimaginável até então" ${ }^{13}$.Posteriormente, o sucesso dessas intervenções tornou o modelo parisiense a grande referência para grandes cidades no mundo todo depois de 1870 - inclusive no Brasil -, principalmente pelo seu aspecto simbólico mas também pelo funcional. Aqui nos vale notar como, diferentemente dos períodos anteriores, a questão da circulação urbana passa a se tornar elemento fundamental de projeto.

A ativa participação do prefeito do Departamento do Sena (Paris) Georges-Eugène Haussmann, com amplo apoio do Imperador Napoleão III, foi fundamental para a o sucesso das intervenções parisienses. Advogado de formação e funcionário público de carreira, Haussmann possuía estreitos laços e grande proximidade com o imperador. Além de conhecer a cidade em seus mínimos detalhes, era muito bem assessorado por especialistas de diversas áreas, ao mesmo tempo que, metodicamente, mantinha o controle sobre todos os detalhes das operações. Considerado "grande, vigoroso e enérgico" foi capaz de intervir na cidade por dezessete anos consecutivos, e com o respaldo do imperador, blindava suas intervenções das críticas dos opositores ${ }^{14}$.

A resposta de Haussmann é singular a partir do momento onde ele propõe uma solução global para o problema colocado. A cidade era tratada em sua totalidade, pensada e organizada em forma de redes e sistemas: circulação, áreas verdes ${ }^{15}$, distribuição de água e captação de esgoto. Desse modo, todas as camadas da população seriam atendidas pelos serviços a serem instaurados. Choay afirma que o tratamento "holístico" concebido para

12 De acordo com o próprio Haussmann, através de seu caderno de memórias, os principais problemas a serem enfrentados na remodelação de Paris estavam três itens fundamentais, relacionados ao arruamento da cidade (CHOAY, 2000: p.11):

A circulação: sua ineficácia era resultado da estreiteza das ruas, em sua maior parte medieval, preparada apenas para pedestres. Sobretudo, sentia-se falta de da existência de ligações diretas entre os pontos cardiais da cidade e de ligações diretas entre os bairros, oriundos de estruturas constituintes de entidades autônomas.

A higiene: os bairros pobres sofriam com a chegada de mais e mais pessoas às cidades. Faltava iluminação e ventilação natural nas casas e as ruas eram especialmente estreitas, gerando espaços insalubres que comumente propiciavam o surgimento de epidemias.

A paz social: o tecido viário estreito e tortuoso favorecia a insurgência de revoltas populares. Vale ressaltar que durante toda a primeira metade do século XIX a França se encontrava em estado de grande instabilidade: desde a queda da bastilha de 1789 o país passou por sete regimes políticos num período de cerca de 80 anos, até o estabelecimento da terceira república, em 1870. Segundo a autora, "sua repressão era um dos objetivos mais comumente apresentados nas intervenções Haussmannianas". Apesar de menos citada no caderno de memórias de Haussmann, a criminalidade também era outro aspecto a ser considerado como problema social a ser enfrentado.

13 BERMAN, 1986: p.145.

14 CHOAY, 2000: p. 28

15 A vegetação passa a fazer parte do repertório dos espaços públicos urbanos, através de uma hierarquia de elementos que variavam da pequena escala - como mobiliário urbano; bulevares arborizados - passando por uma média escala - de quiosques e praças -, chegando a grande escala - de edifícios públicos, parques e bosques. 
a intervenção constituiu o fundamento epistemológico sob o qual se institui em seguida a disciplina do urbanismo, tornando as intervenções de Haussmann o primeiro paradigma de metrópole industrial ${ }^{16}$. Em particular, as intervenções parisienses revelam muitos dos problemas que mais tarde seriam enfrentados em outras grandes cidades do século XX, tanto na proposição do problema, quanto nas formas de viabilizar sua implementação. Por fim, já é possível ver naquela Paris um novo conflito, onde um eficiente sistema de circulação se choca com a vida urbana de uma grande cidade.

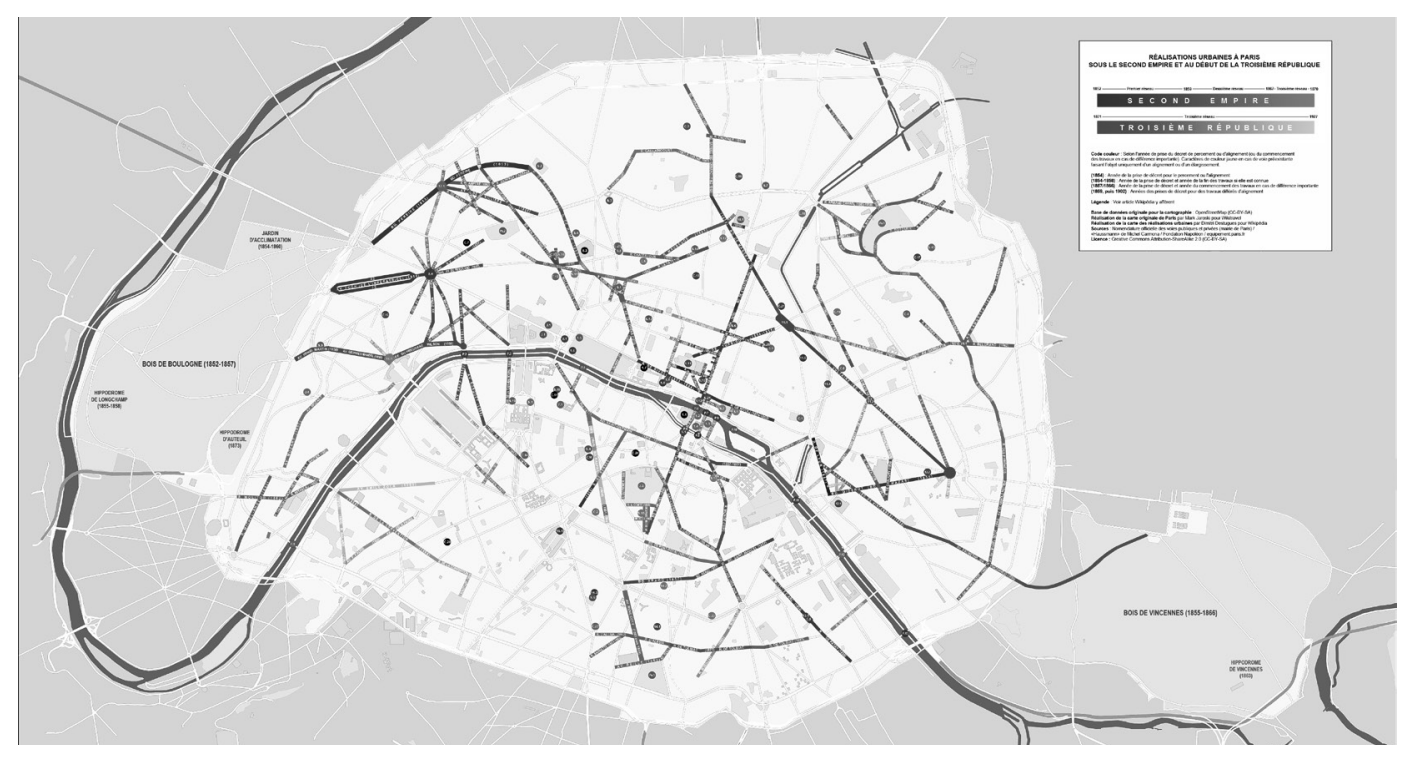

Figura 23 | Mapa das intervenções Haussmannianas na cidade de Paris.

Inspirado nas intervenções urbanas da cidade de Londres, que conhecera durante os anos de exílio, o plano de Napoleão III tinha como objetivo o embelezamento do centro monumental de Paris, conectar as gares ferroviárias - próximos às antigas muralhas, de onde saiam as estradas reais - e organizar e abrir novas vias mais largas como forma de conter motins. Também havia grande preocupação na conexão entre centro e periferia da cidade: a circulação central seria solucionada a partir da "grande croisée", o cruzamento de duas largas vias centrais, no sentido Leste-Oeste ${ }^{17} \mathrm{e}$ Norte-Sul ${ }^{18}$, formando-se a rede principal de onde derivaria uma rede secundária. De acordo com Lavedan, Haussmann mostra em suas memórias como, no momento de definição do traçado das ruas, estava mais preocupado com alinhamentos e perspectivas, enquanto que o imperador estava mais preocupado com as questões relacionadas à circulação ${ }^{19}$.

16 "Ce traitement holistique, sans précédent, apliqué à la ville, contitue le fondement épistemologique sur lequel ont été édifiées, presque simultanément, et l'intervention de Haussmann qui a fait de Paris le permier paradigme de la métropole industrielle et la discipline (I'urbanisme) qui s'assigne de transformer l'espace urbain en objet de science apliquée». (CHOAY, 2000: p.12)

17 Formado pelas vias: Rue de Rivoli e Rue Saint Antoine.

18 Formado pelas vias: Boulevard Strasbourg e Boulevard Sebastopol.

19 Apud. SAKAGUCHI, 1998: p.156-157. 


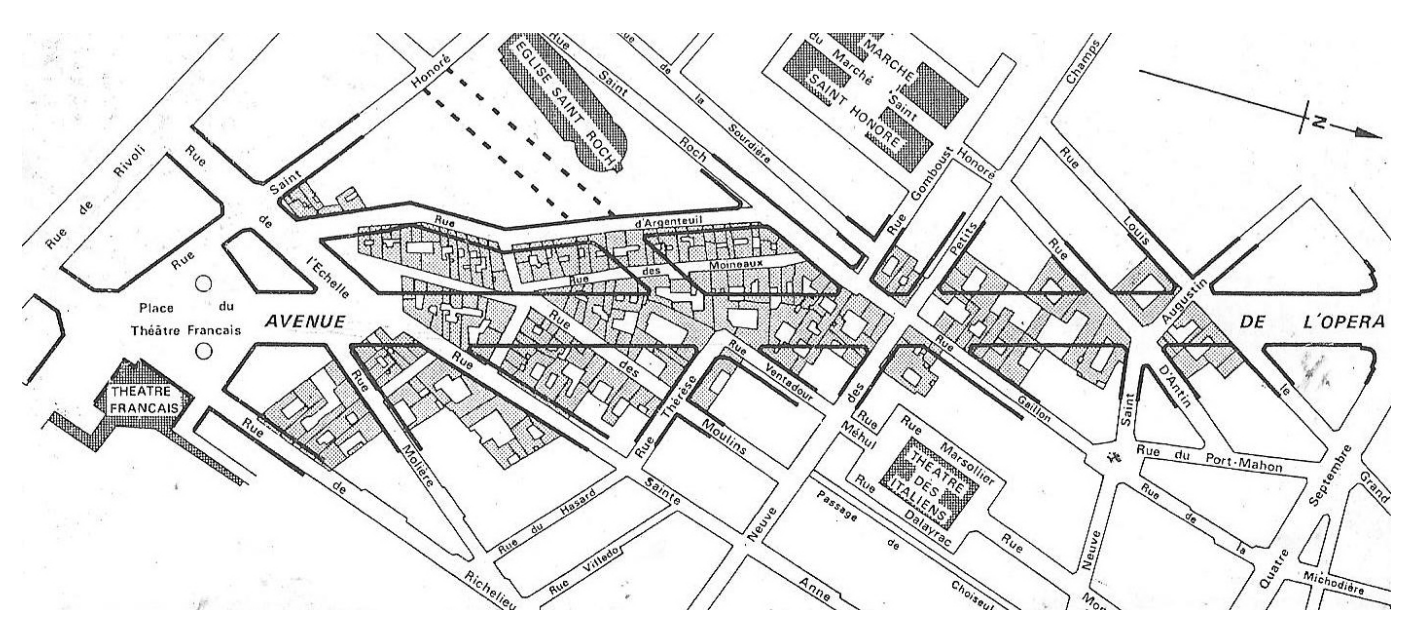

Figura 24 | Planta de um típico "percement"

A estratégia de transformação urbana se baseava na abertura de "percements", novas vias no tecido existente, substituindo o alargamento do antigo traçado que se tornou anacrônico e ineficaz por largos bulevares em linha reta, aumento de escala das trocas e do tráfego da cidade. O traçado das novas avenidas era determinado pela ligação direta, sem concessões, entre dois - ou mais - pontos importantes da cidade. A ideia de melhorar a viabilidade de Paris não ocorreria de forma lenta, onde a cidade se refaz a medida que as edificações lindeiras são construídas. Pelo contrário, abria-se diretamente uma passagem através dos maciços das quadras expropriando-as ${ }^{20}$ e destruindo edifícios inteiros que estivessem sobre o local onde as novas vias estavam traçadas. A retificação no eixo vertical também era fundamental para o sucesso da intervenção, resultado de "verdadeiras estratégias topográficas" sobre a Paris medieval acidentada e com muitas ladeiras ${ }^{21}$. A lógica cartesiana era imposta ao contexto topográfico, histórico e social. A destruição do que estava no caminho era implacável, a velha cidade medieval precisava ceder passagem à nova cidade burguesa.

Talvez uma das operações mais engenhosas do processo tenha sido o seu financiamento, através de bancos de investimento. Enquanto o dinheiro público bancava as desapropriações, essas instituições financiavam a construção das novas vias, tendo como contrapartida a permissão para a exploração imobiliária das suas margens ${ }^{22}$. Esse processo aproximou investidores e interesses estatais, criando base política e econômica para o amplo desenvolvimento de estratégias de reconstrução. Como afirma Argan, as intervenções estavam alinhadas com os interesses burgueses, caracterizadas como "típica intervenção do poder sobre a imagem e a funcionalidade urbana", que "melhorou o fluxo do trânsito viário, enriquecem a cidade com amplas perspectivas", respondendo "claramente a um interesse de classe" ${ }^{23}$, facilitando aos investidores a especulação dos imóveis urbanos.

20 Em diversos casos as terras desapropriadas pertenciam a antigas famílias nobres. CHOAY, 2000: p.13.

21 "Le réseau viaire) met en communication directe points cardinaux et équipements névralgiques situés sur les deux rives de la Seine, selon de grands axes est-ouest et nord-sud, completés par des voies diagonales et des places qui jouent le rôle d'échangeurs de circulation au centre de sous-systemes (de l'Étoile, de Chaillot, de la République...)". Ibid.: p.13.

22 GIEDION, 2004: p.787-789.

23 ARGAN, 1992: p. 185. 


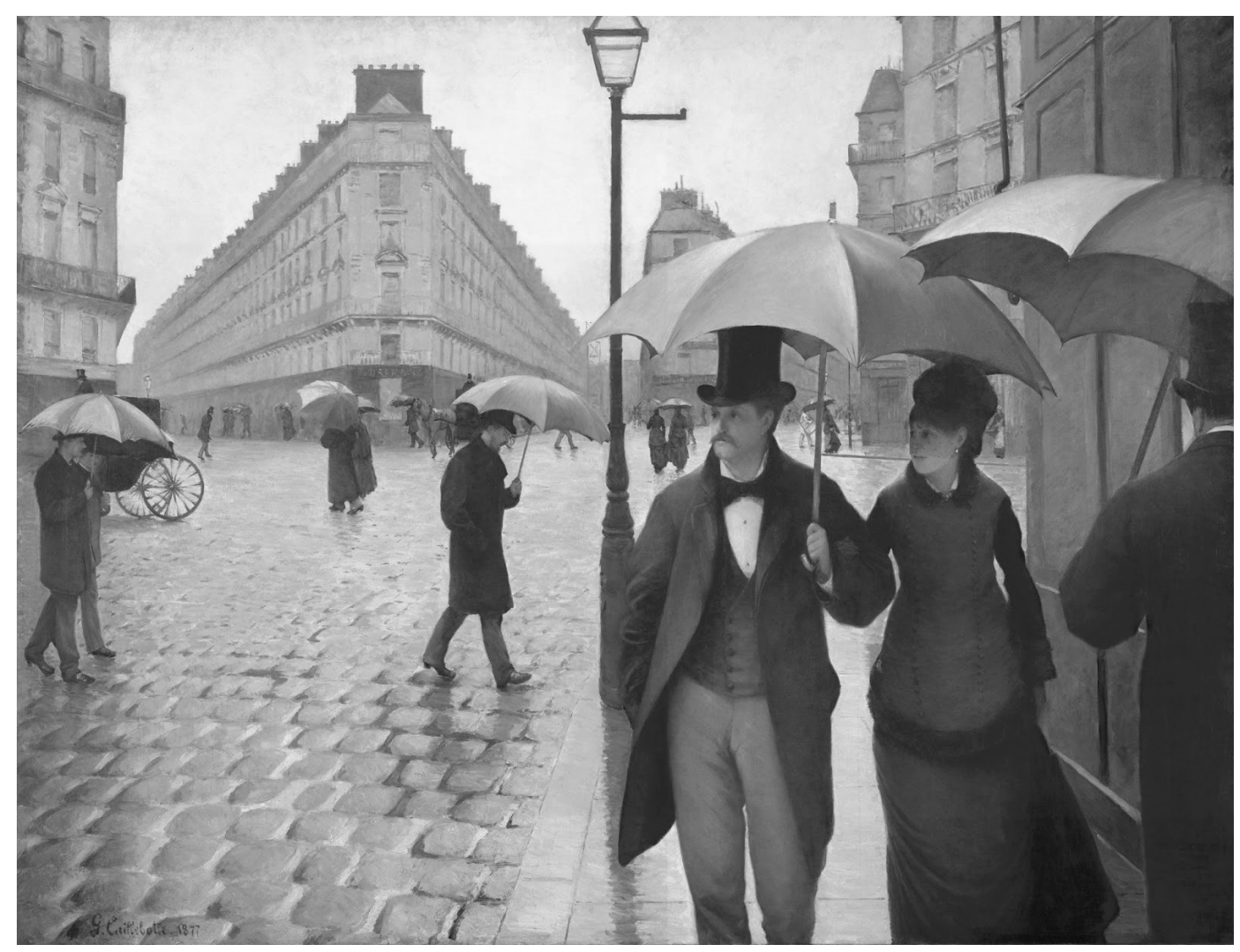

Figura 25 | Gustave Caillebotte - "Jour de pluie à Paris,"1877

Por mais que hoje a Paris Haussmanniana esteja consagrada como uma das mais belas cidades do mundo, seus contemporâneos a criticavam recorrentemente do ponto de vista estético. A acusavam recorrentemente de pecar pelo seu "gigantismo" e sua "monotonia"; a criticavam pela "ausência de estilo" e "pobreza geométrica" ${ }^{24}$. Em suas memórias, Haussmann demonstra que a estética era uma de suas grandes preocupações. Ele estava plenamente consciente da crise pela qual a arquitetura passava naquele momento, período de transição entre dois mundos, anterior e pós-revolução industrial, onde se abria o que Choay chama de "a era do engenheiro" ${ }^{25}$. Ela também expõe, através dos escritos do interventor, a forma como os arquitetos mais perspicazes do período - como Viollet-le-Duc - estavam presos ao pensamento romântico, ligado a um anacronismo, sendo estes incapazes de inventar um estilo novo que respondesse a uma nova civilização, ameaçada pela ciência e 'pela impecável correção dos engenheiros'. Tais forças, segundo ele, poderiam bem 'reduzir o arquiteto à figura do desenhista, decorador ${ }^{26}$. Na verdade, segundo a autora, é seu plano global de 'regularização' que lhe permitiu dotar a capital desse estilo que não era 'nem arquitetura contemporânea, nem a estética urbana neoclássica, nem tampouco a unidade e coerência de um estilo'. Segundo ela, François Loyer afirma que Haussmann inventa uma nova tipologia arquitetônica, a do 'edifício de habitação especulativa'. Eles possuem 'aspecto monumental' e 'dão coesão para o conjunto' ${ }^{27}$. 


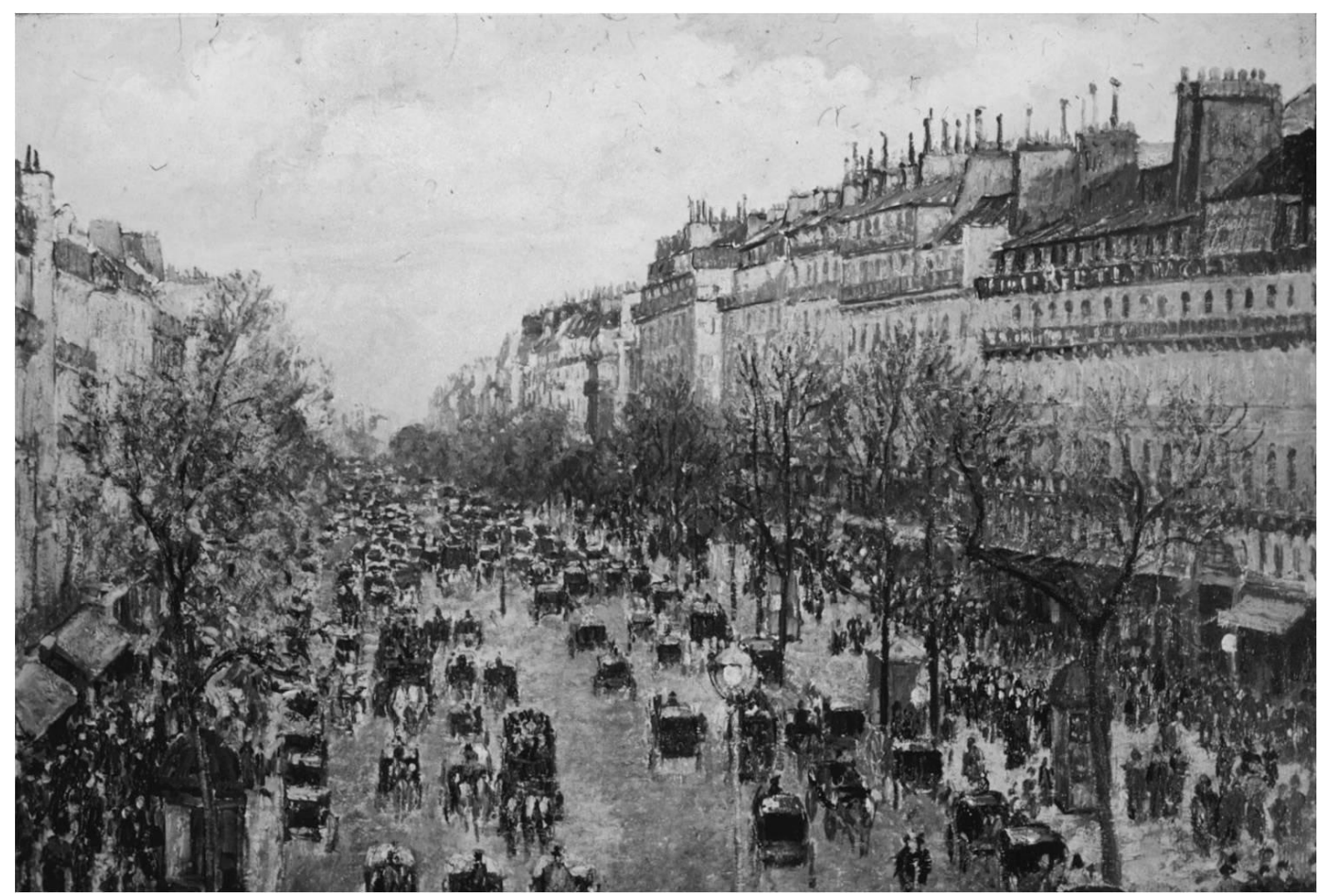

Figura 26 | Camille Pissaro - "Boulevard Montmartre,"1897

Para Pierre Pinon, Haussmann também estava interessado no caráter territorial de suas intervenções, muito semelhante àquela do engenheiro que traça estradas com a linha reta traçada pela mira de um teodolito. Segundo esta lógica, na cidade Haussmanniana, 'as ruas se alinhariam seguindo o modelo das estradas e das redes ferroviárias' ${ }^{28}$, como se a estrada penetrasse diretamente na cidade. Com o passar do tempo, foi possível notar que essas amplas estradas, meticulosamente retas, estendendo-se por quilômetros, seriam vias velozes, ideais para o tráfego pesado ${ }^{29}$. Como observa Berman:

"Pela primeira vez, corredores e condutores podiam, no coração da cidade, lançar seus animais em plena velocidade (...) o aperfeiçoamento das condições carroçáveis não só aumentavam a velocidade do tráfego previamente existente, mas - como as rodovias do século XX farão em escala ainda maior - colaboraram para gerar um volume novo de tráfego mais intenso que o anterior, para além do que Haussmann e seus engenheiros haviam previsto" ${ }^{30}$.

As ideias preconizadas no urbanismo Haussmanniano ecoaram em diversas partes do mundo. A partir do modelo urbanístico desenvolvido na Europa, diversas cidades - particularmente na América - ambicionaram modernizar seu espaço urbano de forma organizada e monumental, tendo por lema a "ordem" e como guia a "beleza" ${ }^{31}$. A esse movimento foi 
dado o nome City Beautiful. O arquiteto e urbanista Daniel Burnham, considerado o profeta desse movimento urbanístico ${ }^{32}$, foi responsável - dentre outros projetos urbanos - pelo desenvolvimento do Plan of Chicago, de 1909.

Burnham pretendia aplicar os conceitos transformadores do tecido urbano de Paris ao contexto urbano norte-americano do início do século XX. Ele afirmou que, "a tarefa realizada em Paris corresponde ao trabalho que precisa ser feito em Chicago" ${ }^{33}$. O plano dava grande ênfase ao arranjo e projeto viário, através de esquemas de "regularização" no estilo Haussmanniano, impondo um esquema radio-concêntrico a uma cidade com malha viária quadriculada. A ambição do plano almejava a extensão das artérias radiais em direção ao interior, criando a partir da cidade uma rede de estradas que viabilizavam o crescimento virtualmente infinito da mancha urbana, adequando a cidade ao extraordinário crescimento populacional iniciado no final do século XIX.

Burnham mesclou aos princípios de Haussmann alguns conceitos do urbanismo norte-americano. Parte fundamental - e bem-sucedida - de seu plano previa a implementação de um sistema de áreas verdes conectado através de uma parkway ao longo das margens do lago Michigan. O urbanista foi capaz de tornar a frente d'água da cidade um grande espaço público, preservado até hoje como tal. Vale frisar que as parkways presentes nos esquemas do Movimento City Beautiful de maneira geral eram na verdade mais parecidas com os bulevares parisienses, caracterizadas como largas avenidas, com vasto uso de vegetação disposta de forma linear, sem se caracterizar como via de acesso exclusivo. Desse modo, elas devem ser diferenciadas das parkways desenhadas como vias expressas ${ }^{34}$.

Assim como no urbanismo de Haussmann, as ruas do urbanismo City Beautiful tinham claramente função de espaço de circulação. Entretanto, seu aspecto estético e monumental era parte indissociável do esquema, criando espaços públicos e composições de desenho urbano de grande escala ${ }^{35}$, que primavam pelo seu aspecto monumental, ao invés de serem guiadas por critérios de vazão e eficiência de tráfego. A tomada das ruas pelos automóveis e a ineficiência do esquema viário existente até então transformariam as prioridades urbanas, colocando os aspectos estéticos e de desenho em segundo plano diante delas. 


\title{
3.2. AS FORMULAÇÕES RODOVIARISTAS URBANAS
}

Preocupados com o futuro das cidades, não tardou para que a criatividade dos urbanistas fosse estimulada pela presença do automóvel no ambiente urbano. Já na década de 1910 surgiam as primeiras visões de cidade futura. Desde então, já era perceptível a necessidade de segregação entre a velocidade do automóvel e a vida urbana das ruas, com base no que já ocorria com as ferrovias e redes de metrô que cortavam as grandes cidades do ocidente. A saturada capacidade viária dos densos centros urbanos, aliada à falta de regulamentação do trânsito levavam os urbanistas da época a imaginarem formas de viabilizar o trânsito dentro da cidade tradicional, ao separar os homens do caos e do perigo das ruas. Como afirma Jean-Louis Cohen:

\begin{abstract}
"nesse período breve, mas fértil, (...) engenheiros, arquitetos, paisagistas e reformadores sociais, comprometidos com o problema da grande cidade, propuseram um terceiro conjunto de princípios, evitando tanto a imitação passadista quanto a retórica grandiloquente, a rápida popularização do automóvel e a implantação dos metrôs induziram uma visão da cidade como uma gigantesca máquina para circular ${ }^{136}$.
\end{abstract}
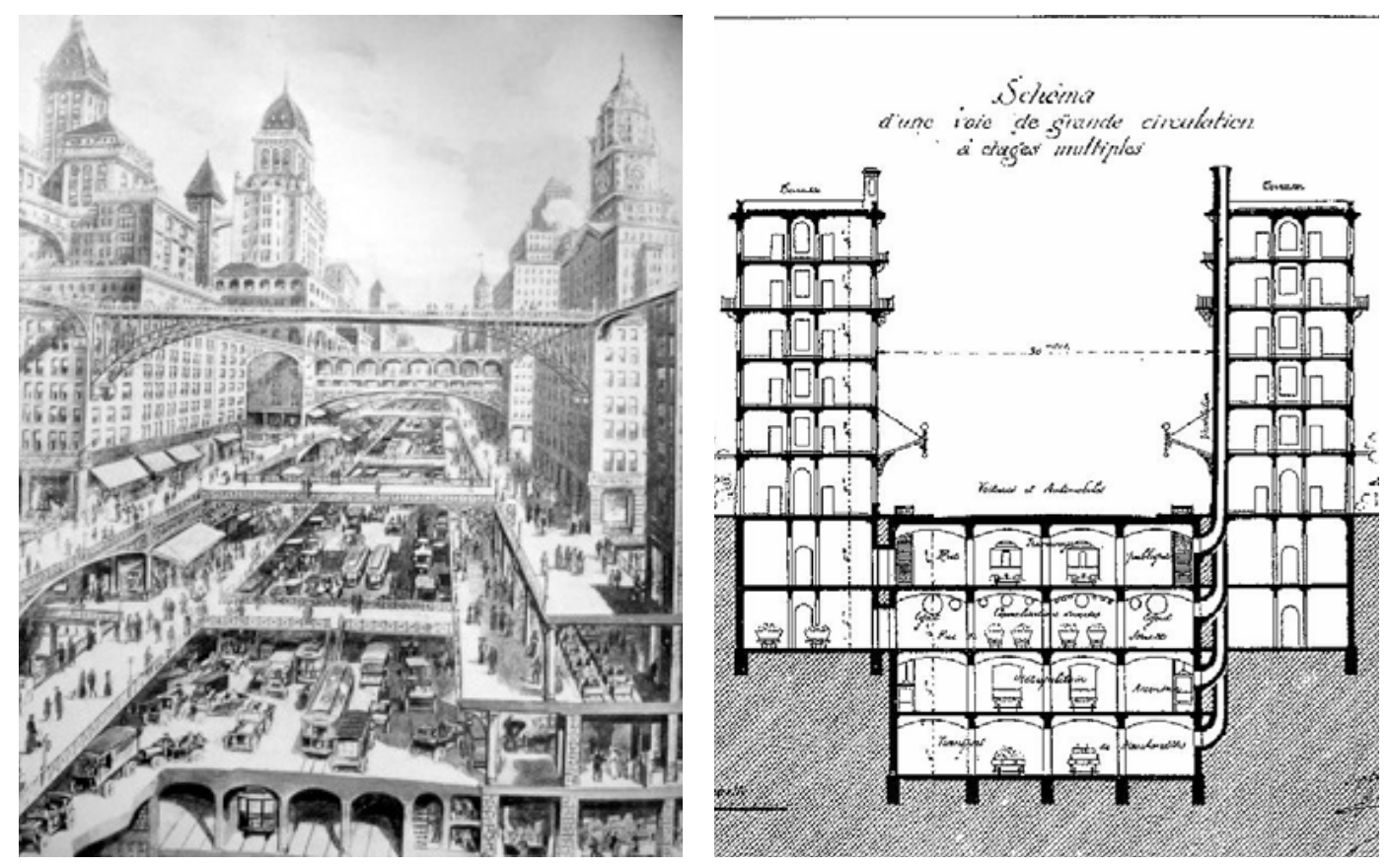

Figura 27 | H. W. Corbett: "City of the Future", 1913

Figura 28 | E. Hénard: "City of the Future", 1910 
O arquiteto Harvey Wiley Corbett, professor da Universidade de Columbia, em Nova lorque, foi um dos primeiros urbanistas norte-americanos a apresentar propostas de transformação do espaço urbano dos centros empresariais. Defensor dos arranha-céus, Corbett buscava, já em 1913, soluções de desenho da rua que viabilizasse a densidade proposta pelos edifícios altos das grandes cidades americanas, cujas ruas já estavam congestionadas pelo tráfego de automóveis. Nessa época, poucos culpavam o desenho viário pelo problema, enquanto alguns culpavam os edifícios altos por atrairem tantas pessoas para um único endereço. No entanto, o automóvel individual era considerado o principal responsável pelo trânsito. Como observou Corbett, "todos culpam o automóvel" ${ }^{37}$.

Ao contrário das propostas haussmannianas, que arrasavam a cidade existente com o objetivo de criar vias largas, sua visão pretendia viabilizar a presença dos automóveis nos densos centros urbanos utilizando nas ruas o mesmo princípio dos lotes: a verticalização. Ao sobrepor diversas camadas sobre as ruas existentes, sua capacidade de vazão aumentaria, separando diversos tipos de tráfego e funções, como propusera o arquiteto e urbanista Eugène Hénard na França, poucos anos antes.

Hénard é considerado o primeiro autor da "teoria geral da circulação", pai da primeira rotatória - construída em Paris, em 1907. Em sua proposta de cidade futura - apresentada em uma conferência em Londres, em 1910 - o arquiteto defendia a segregação do tráfego de veículos e pedestres das demais necessidades de circulação ${ }^{38}$, através de vários níveis subterrâneos - como em um edifício -, ao invés de que ocorria com a rua tradicional:

"Todo o mal nasce dessa velha ideia tradicional de que o solo da rua deve ser estabelecido ao nível do solo natural primitivo." No entanto, parte-se da hipótese de que "os calçamentos e as calçadas devem ser artificialmente estabelecidos a uma altura suficiente para deixar, embaixo, um espaço capaz de conter todas as canalizações. (...) Em princípio, os calçamentos e calçadas seriam construídos de uma vez por todas, como um tabuleiro de ponte. Esta plataforma, [seria] construída à altura de 5 metros acima do solo natural."

"Se generalizarmos esta disposição, seremos levados a conceber uma cidade cujas ruas de tráfego intenso teriam, proporcionalmente à intensidade desse tráfego, três ou quatro plataformas superpostas: a primeira para os pedestres e os carros, a segunda para os bondes, a terceira para as canalizações diversas e a evacuação do lixo, a quarta para o transporte de mercadorias, etc. Teríamos assim a rua de vários andares, como temos os prédios com andares, e o problema geral da circulação poderia ser resolvido, qualquer que fosse a intensidade dela ${ }^{\prime 39}$.

37 NORTON, 2008: p. 61.

38 Alguns autores (MOOS, 1971; GIEDION, 2004) apontam a primazia da segregação viária nos esquemas de Leonardo da Vinci para a "Cidade Ideal" (1487-1490); Em 1860, um médico do campo francês, Tony Moilin, propôs construir uma cidade onde ruas e caminhos de ferro estariam em níveis diferentes. Antes de 1900, as grandes metrópoles - Paris, Berlim, Londres, Nova lorque, Chicago - realizaram uma separação das vias de circulação com a construção de linhas de metrô subterrâneas ou em via elevada.

39 HÉNARD Apud. CHOAY, 1965: p. 250 e 252. 


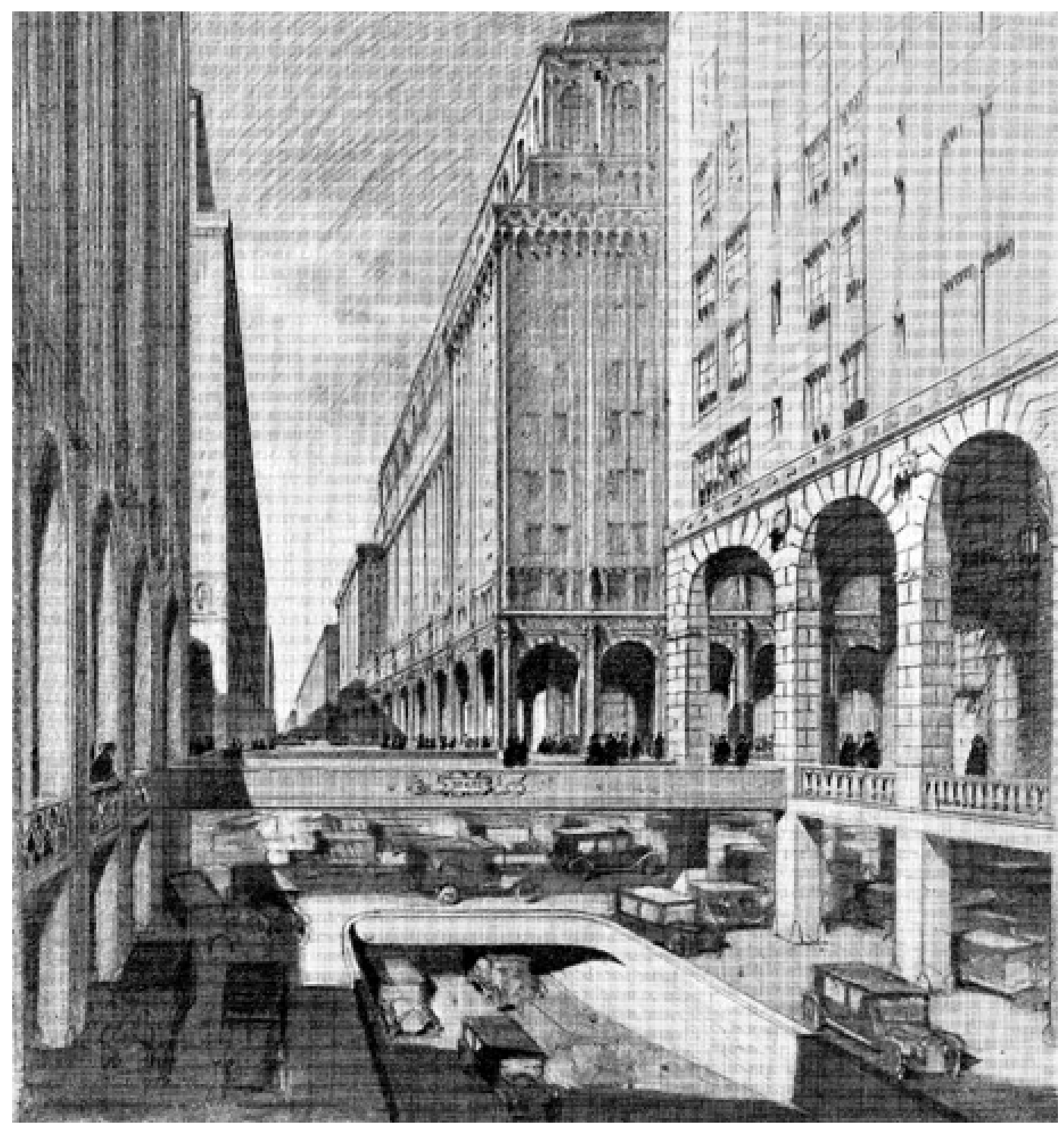

Figura 29 | H. W. Corbett: Proposta para Manhattan, 1923

Já a proposta para a "Cidade Futura" concebida por Corbett, em 1913, segrega pela primeira vez os pedestres do trânsito dos automóveis. O historiador Jean Louis Cohen ressalta o radicalismo da visão do urbanista, onde "cânions vertiginosos onde se sobrepõem vias de trânsito rápido e calçadas suspensas, guarnecidos por arranha-céus ligados entre si por linhas elevadas de metrô à altura do quadragésimo andar" ${ }^{\prime 4}$. Já o arquiteto Rem Koolhaas, pesquisador da história de Manhattan, destaca o novo caráter que ganharia a rua urbana, tornando-a exclusivamente em infraestrutura: "a superfície total da cidade - agora um caos com todos os tipos de transporte - seria gradualmente entregue apenas ao tráfego de automóveis." ${ }^{41}$ O viés funcionalista dado ao espaço da rua na visão urbana de Corbett fica ainda mais claro na proposta que ele desenvolve para Manhattan, em 1923. Nela, o urbanista propõe uma transformação da calha da rua através de arcadas para pedestres. Nas palavras do próprio autor:

40 COHEN, 2013: p.75

41 KOOLHAAS, 1978: p.147 
"Vemos uma cidade de calçadas, dispostas em arcadas dentro do alinhamento dos edifícios, um andar acima do atual nível da rua. Vemos pontes em todas as esquinas, da largura das arcadas e com parapeitos sólidos. Vemos os parques menores da cidade (e acreditamos que ainda haverá muitos outros) erguidos no mesmo nível das passarelas (...) e o aspecto todo passa a ser o de uma Veneza muito modernizada, uma cidade de arcadas, praças, pontes, os canais como ruas, salvo que os canais não estarão cheios de água de verdade, e sim de um trânsito motorizado fluindo livremente, o sol brilhando no capô negro dos carros e os edifícios se refletindo nesse fluxo ondulante de veículos que rodam velozes. De um ponto de vista arquitetônico e em relação à forma, à decoração e às proporções, a ideia apresenta todo o encanto de Veneza, e um pouco mais. Não há nada de incongruente nisso, nada de estranho" ${ }^{\prime 42}$.

É notável como Corbett compara o fluir das águas dos canais de Veneza com o fluxo contínuo dos carros na metrópole. Essa analogia dará margem a futuras intervenções urbanas que encararão vias expressas como verdadeiros rios que exigem uma ponte para serem transpostos. O projeto seria implementado de forma gradual, com as arcadas separando o tráfego de pedestres dos automóveis. Dessa forma, segundo o autor, capacidade viária aumentaria em pelo menos $200 \%$. Esse percentual aumentaria ainda mais se a rua consumisse seções mais largas do solo urbano, sob os edifícios, onde, em última análise, sua superfície total da cidade poderia se converter em área exclusiva de tráfego, um verdadeiro "oceano de carros" ${ }^{43}$.
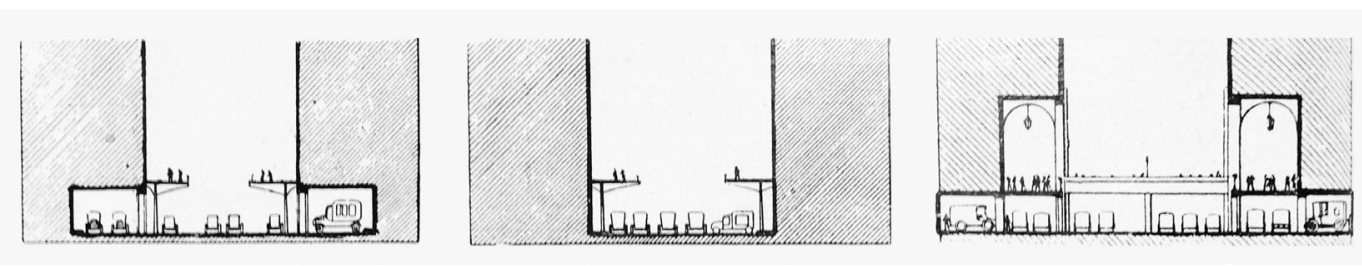

Figura 30 | Proposta para aliviar o trânsito em Nova lorque em suas fases de implementação

Os pesquisadores DiMento e Ellis afirmam que diante do contexto das cidades norte-americanas no início do século XX, arquitetos não eram responsáveis pelas construções públicas, sendo suas visões meras especulações. Em contrapartida, a força de suas ilustrações definitivamente colaborou com a disseminação de uma nova imagem de cidade, ligada ao progresso e ao futuro. Tais imagens - assim como outras produzidas por Hugh Ferris e Raymond Hood - lançaram luz sobre alternativas ao problema do trânsito, tornando o conceito de vias expressas urbanas mais aceitável perante a opinião pública ${ }^{44}$.

Posteriormente, as propostas de Corbett - largamente difundidas na Europa pela revista L'Illustrazione Italiana, em 1913 - impressionaram o arquiteto futurista Sant'Elia, que idealizou uma cidade como "um imenso canteiro de obras, tumultuado, ágil, móvel, dinâmico em cada uma de suas partes" ${ }^{45}$. Em seu projeto La Città Nuova, de 1914, ele se apropria das 
proporções verticais da metrópole norte-americana misturadas a formas aerodinâmicas, imaginando espaços públicos compostos por vias de automóveis em alta velocidade, traduzindo o fascínio dos futuristas com a velocidade para o âmbito da arquitetura e do desenho urbano. Conjuntamente com o projeto, San'Elia também lança no mesmo ano em Milão o "Manifesto da Arquitetura Futurista", onde explora conceitos semelhantes:

"Perdemos o sentido do monumental, do pesado, do estático, e enriquecemos a nossa sensibilidade pelo gosto do leve, do prático, do efêmero e do veloz. Sentimos de não sermos mais os homens das catedrais, dos palácios, das ágoras; mas dos grandes hotéis, das estações ferroviárias, das ruas imensas, dos portos colossais, dos mercados cobertos, das galerias luminosas, das avenidas lineares, das demolições salutares. Os elevadores não devem esconder-se como vermes solitários nos vãos das escadas; mas as escadas, tornadas inúteis, devem ser abolidas e os elevadores devem prender-se, como serpentes de ferro e vidro, ao longo das fachadas. (...) A rua, a qual não se estenderá mais como um tapete ao nível das portarias, mas se afundará na terra por vários planos, que acolherão o tráfego metropolitano e serão unidos por trânsitos necessários, por passarelas metálicas e por velocíssimos tapis roulants ${ }^{\prime \prime 4}$.

Sant'Elia descreve a sua cidade como "um imenso canteiro de obras, tumultuado, ágil, móvel, dinâmico em cada uma de suas partes" ${ }^{\prime 47}$. No entanto, apesar de descrevê-la como um espaço tumultuado, suas imagens não mostram - ao contrário da cidade futura de Corbett - a "cidade da congestão" descrita por Koolhaas ${ }^{48}$. As imagens de Sant'Elia são marcadas por uma arquitetura vertical, opressora e pela aridez de seus espaços públicos. Pouquíssimos vestígios de presença humana são encontrados, apenas poucos carros trafegando em velocidade em meio às largas ruas segregadas do nível principal da cidade. Contemporânea à obra de Sant'Elia estão as propostas de Mario Chiattone, que de forma semelhante amplia o rol de especulações futuristas sobre a cidade.

Todos esses projetos, anteriores a Primeira Guerra Mundial, apresentam-se como utopias genéricas, que olham para um futuro que poderia acontecer em qualquer parte. As imagens que, quando concebidas, pareciam fantásticas, partiam de princípios técnicos sólidos, podendo, quem sabe, tornar-se realidade em um futuro não tão distante. Como coloca Argan, esses projetos acabam por transpor o conceito de "sublime" da natureza para a tecnologia.

"O componente utópico do urbanismo, que ainda hoje devemos considerar uma constante, nada mais é do que a extrema ramificação da poética romântica do 'sublime' ou o transcendente é dado como subjugado pelo esforço tecnológico do homem,"A9.

Como forma de quebrar as relações entre cidade e natureza, como afirma Argan, as propostas de cidades futuras apontam para a quebra da relação da cidade com o solo, com o horizonte, propondo espaços urbanos distantes do solo - acima ou abaixo dele: "os pro-

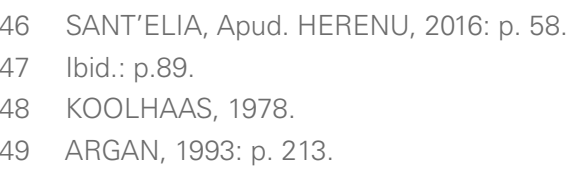


jetistas da cidade do futuro parecem ter horror ao plano, ao nível natural do terreno, aquele que sempre foi concebido como o plano da terra, da vida: a cidade do futuro precipita-se nas entranhas da terra ou eleva-se a alturas vertiginosas" ${ }^{50}$.

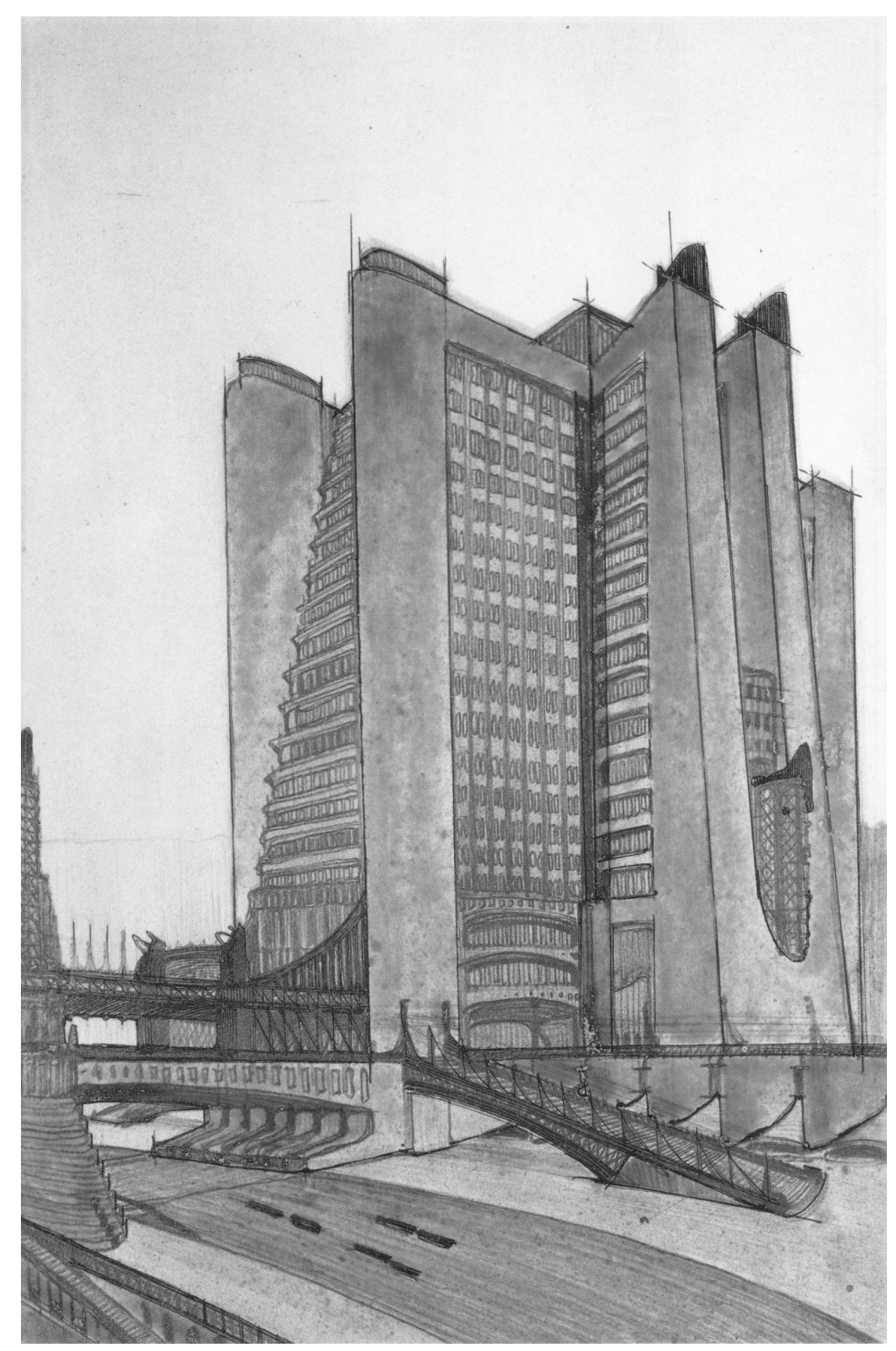

Figura 31 | Sant'Elia - La Cittá Nuova, 1914

Essas visões de futuro se destacam por colocar em primazia as atividades funcionais sobretudo de circulação - em detrimento de qualquer outra atividade que pudesse ocorrer ao longo dos espaços públicos. Nas imagens não se vê nada além de atividades relacionadas a circulação. São projetos que ainda utilizam a rua tradicional como referência, adaptando-a para as necessidades do mundo moderno, alterando o mínimo possível a relação entre rua e edifício. No entanto, apesar dos projetos manterem o mesmo "primado da mobilidade" - norteador da proposta de Haussmann para Paris -, é notável como poucos anos após a invenção do automóvel a segregação da sua circulação já se impõe em relação ao restante das atividades urbanas. A rua não deve oferecer obstáculos, pois a velocidade do automóvel deve ser explorada ao máximo. 


\section{LE CORBUSIER ENFRENTANDO CIDADE TRADICIONAL}

A Primeira Guerra Mundial transforma o panorama das cidades - sobretudo na Europa que exigiam mudanças de caráter emergencial. Como afirma Argan, é a partir da década de 1920 que as especulações de cidades futuras começam a tomar corpo e construir novos paradigmas. "O problema urbanista, que antes da guerra se apresentava como prefiguração quase utópica de uma situação que ocorreria no futuro, agora se apresenta com extrema gravidade e premência" ${ }^{51}$. A cidade se encontrava diante de uma situação social, econômica e tecnológica profundamente modificada: a guerra havia acelerado por toda a parte o desenvolvimento da indústria, tanto em sentido quantitativo quanto pelo progresso tecnológico ${ }^{52}$. Enquanto o lobby automobilístico clamava por mudanças no espaço viário por conta das crises de circulação nos centros urbanos, a cidade não acompanhava o ritmo do desenvolvimento tecnológico. Como novamente afirma Argan:

"Devido à transformação quantitativa e qualitativa de seus conteúdos e seu dinamismo funcional, como também ao crescente desenvolvimento da mecanização dos serviços e transportes, a estrutura da cidade já não responde às exigências sociais (...). Possui um aspecto funcional: a cidade é um organismo produtivo, um aparelho que deve desenvolver certa força de trabalho, e, portanto, precisa se libertar de tudo o que emperra ou retarda seu funcionamento, ${ }^{\prime 53}$.

Para o arquiteto, as questões relacionadas à circulação eram problema fundamental da nova reformulação do urbanismo. A cidade tradicional deveria abrir espaço para meios mais eficientes de circulação, adequando-se às novas tecnologias. Ao analisar as condições de Paris no primeiro pós-guerra, Le Corbusier observa o descompasso da cidade e das atividades que nela acontecem com o automóvel individual: "o automobilismo é um evento novo com consequências imensas para a grande cidade. (...) pois a forma da rua não é adaptada [ao carro]" ${ }^{54}$. Como destaca Von Moss, "o crescimento da densidade urbana e da motorização fizeram da rua um teatro da perturbação, literalmente insuportável, de suas funções" ${ }^{\prime 5}$.

Paris, capital automobilística da Europa no início do século XX, concentrava já naquele período grande quantidade de veículos, que apesar dos bulevares, não permitia grande fluidez do tráfego. Em seu livro L'Urbanisme, de 1924, Le Corbusier descreve um passeio por um bulevar parisiense repleto de automóveis. Ao ser expulso da rua pelo tráfego o arquiteto relata: "Deixar nossa casa significava que uma vez cruzada a soleira da porta, nós estávamos em perigo e podíamos ser mortos pelos carros que passavam (...) foi como se o mundo tivesse enlouquecido" ${ }^{56}$, ou como ele mesmo descreve de modo mais genérico: "as cidades, onde o automóvel apareceu, tornaram-se desertos de pedras e de asfalto, no barulho e no tédio, com as condições da natureza abolidas e esquecidas" ${ }^{57}$. 
Von Moos enxerga nos trabalhos urbanos de Le Corbusier desse período uma relação marcada por uma "mistura explosiva de amor e hostilidade, de entusiasmo e revolta" ${ }^{58} \mathrm{com}$ a cidade de Paris. É a partir da leitura dos problemas da cidade - da penumbra e da poeira, da poluição atmosférica, da tuberculose e dos bairros miseráveis, bem como dos hábitos estagnantes e de convenções pequeno-burguesas - que o urbanista francês apresentará propostas categóricas de reforma urbana ${ }^{59}$. Suas críticas a Paris sintetizam-se no que ele chama de "Rua Corredor":

"O regime cardíaco legado pelos anos a Paris representa uma rede apertada de "ruas corredores" de cruzamentos curtos (...) provindos das restrições da cidade fortificada; depois uma rede mais vasta, estabelecida por razões mais políticas do que urbanísticas por Luis XIV, Napoleão l e Haussmann. É nessa rede mantida que as velocidades modernas foram atiradas. Pisoteia-se no mesmo lugar" ${ }^{60}$.

A solução apontada pelo urbanista para o problema da incompatibilidade entre veículos e o espaço urbano da cidade tradicional acompanha o ímpeto progressista e revolucionário da época. Ao argumentar, ele caracteriza a rua como uma forma urbana obsoleta, e desse modo, sua permanência no espaço urbano deve ser questionada:

"É a rua do pedestre milenar, é um resíduo dos séculos, é um órgão inoperante, sem credibilidade (...) a rua nos usa (...) ela nos engana, no final das contas. (...) logo, por que é que ela ainda existe?" 61.

Le Corbusier advoga a favor do desaparecimento da rua de modo que ele possa propor uma nova forma de cidade. O urbanista chega a ser claro o bastante e afirma em uma das conferências que realizou na América do Sul:

"Antes de mais nada, vamos limpar o terreno: é preciso matar a 'rua corredor'. Só ingressaremos de verdade no urbanismo moderno após essa decisão prévia" ${ }^{62}$.

O trecho acima mostra que, apesar das críticas ao urbanismo do século anterior, alguns dos princípios de intervenção haussmannianos permanecem presentes na doutrina de Le Corbusier: a necessidade das vias de circulação - marcadas pela mesma lógica cartesiana dos eixos cardeais - penetrarem no tecido existente seriam vitais para a melhora da qualidade de circulação das cidades ${ }^{63}$.

58 MOOS, 1971: p. 138.

59 lbid.: p. 138.

60 LE CORBUSIER, 1979: p. 211.

61 "C'est la rue du piéton millénaire, c'est un résidu des siècles; c'est un organe inopérant, déchu»; "La rue nous use»; "Elle nous dégoûte, en fin de compte»; "Car pourquoi subsiste-t-elle encore?" MOOS, 1971 : p.147. 62 LE CORBUSIER, 2004: p.169.

63 Le Corbusier faz referência aos "percements" haussmannianos acreditando que, como seu antecessor, seu novo urbanismo conseguirá manter diálogos com a cidade histórica. "Se às vezes o leito de certas estradas mestras deixou-se encerrar entre estreitas muralhas da história, a operação cirúrgica traçará um novo leito paralelo apto a receber as velocidades modernas, sem nenhum prejuízo para as testemunhas do passado". LE CORBUSIER, 1979: p. 214. 
"É preciso decidir-se a entrar em Paris. As aberturas necessárias provocarão uma imensa riqueza: (...) os cinco grandes ramos de vias elevadas, em conexão com as auto-estradas das províncias, ou seja, dois grandes eixos de circulação: um Leste-Oeste, o outro Norte-Sul "164.

O problema da circulação não será jamais resolvido por anéis viários girando em volta da cidade. O problema, lembremo-nos, não é girar em volta de Paris, mas aí penetrar ${ }^{\prime \prime 65}$.

No entanto, essas intervenções não seriam realizadas de forma cirúrgica. Pelo contrário, as demolições exigidas seriam mais radicais. Em 1925, o arquiteto apresenta através de uma exposição sua proposta para a situação do centro de Paris, que já esboçava desde $1922^{66}$. Partindo da ideia de que a crise na qual se encontrava a cidade, assim como sua necessária transformação futura, eram uma consequência direta do tráfego motorizado, Le Corbusier procurou para o pavilhão da exposição apoio financeiro com diversos fabricantes de automóvel - Peugeot, Citroën, Voisin. É Gabriel Voisin, arquiteto, aviador e industrial automobilístico que, sem hesitar, concorda em patrocinar o projeto e o batiza com seu nome ${ }^{67}$. Sua proposta é bastante próxima das ideias preconizadas para cidades hipotéticas - Cidade para Três Milhões de Habitantes e Ville Radieuse - criando uma tábula rasa em meio ao consolidado centro de Paris. Previa-se a destruição quase total de uma área praticamente plana que começa na margem ao norte do Sena, até a base do bairro Montmartre. Não tão diferentemente do que fizera Haussmann, em meio à destruição Le Corbusier manteve edifícios isolados, de valor histórico: Louvre, Palais-Royal, Place Vendôme, Place de la Concorde, Arc de Triomphe, algumas igrejas e hotéis particulares. Nas palavras do arquiteto, "o passado histórico, patrimônio universal, é respeitado. Mais do que isso, ele é salvo"68.

O sistema de circulação do Plan Voisin tampouco se diferencia das demais propostas ufbanas de Le Corbusier. Elemento central e organizador do plano, o sistema de circulação rápida substitui a "rua corredor" por vias rápidas, segregadas de outras atividades, dando continuidade às autoestradas nacionais que deveriam cortar a capital francesa. $\mathrm{O}$ corte seco entre a cidade e o plano, representado pela colagem deixa clara a radicalidade e indiferença do arquiteto em relação ao tecido da cidade tradicional. No entanto, talvez mais impressionante aos olhos de hoje seja a passagem da via expressa sobre o trecho restante de cidade existente. Com suas atenções completamente voltadas para o funcionamento de seu novo modelo urbano, a rodovia vinda do interior corta o tecido tradicional com a mesma indiferença que marcaria a entrada das rodovias no espaço urbano pós-Segunda Guerra. No segundo volume da publicação de "obras completas" do arquiteto, a legenda desta imagem trata de não deixar dúvida sobre a equivalência entre as escalas - do plano, da cidade e da rodovia, com cento e vinte metros de largura. Como em uma via expressa elevada, o urbanista lança pela primeira vez a possibilidade de cisão absoluta entre sistema de circulação e contexto urbano, prevendo o que se tornaria uma situação corriqueira nas áreas centrais de grandes centros urbanos ao redor do mundo poucas décadas depois.

64 LE CORBUSIER, 1979: p. 214.

65 Ibid.: p. 211.

66 MOOS, 1971: p. 139.

67 Ibid.: p.139.

68 "Le passé historique, patrimoine universel, est respecté. Plus que cela, il est sauvé». LE CORBUSIER Apud. MOOS, 1971: p.139. 


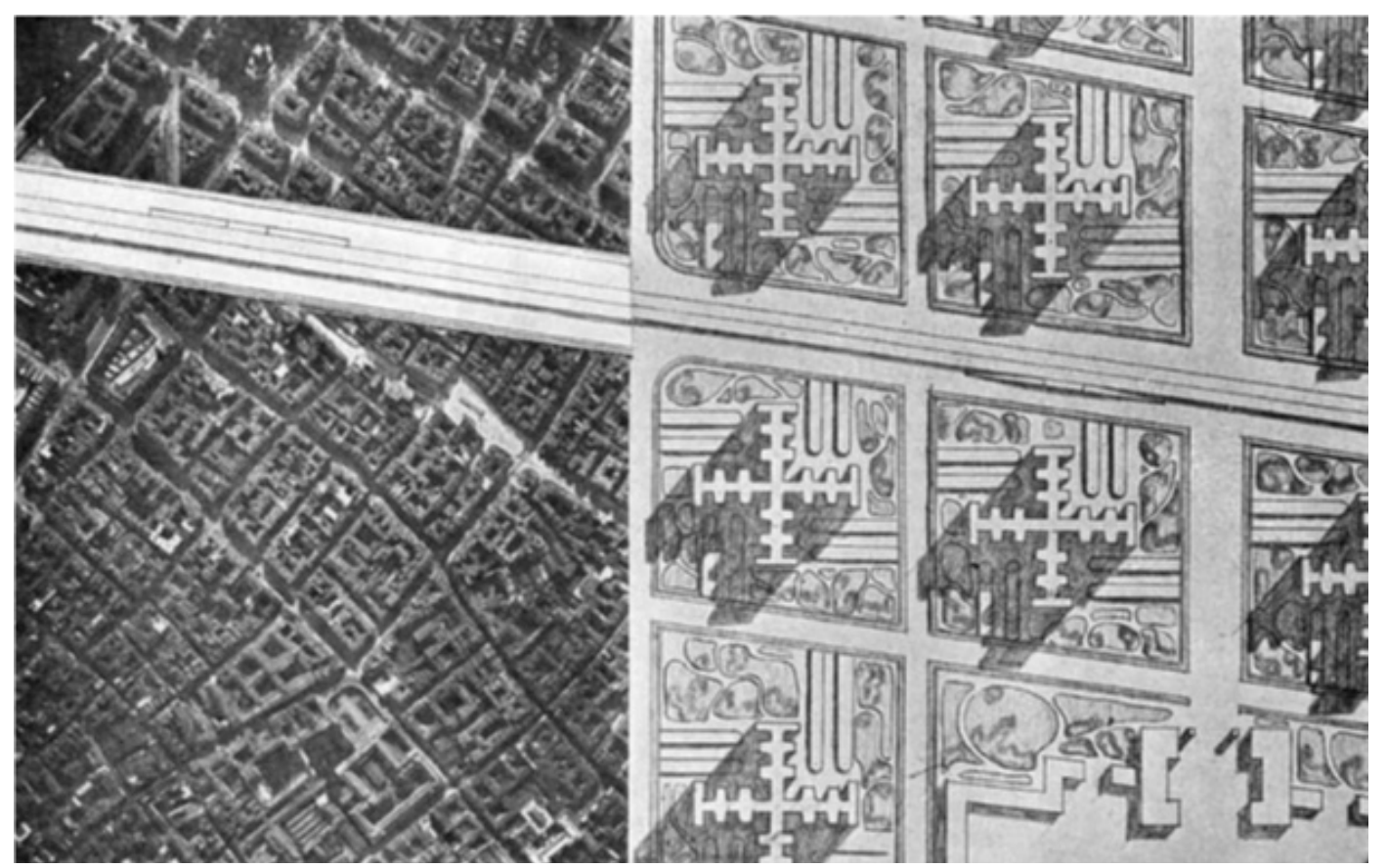

Figura 32 | Le Corbusier - Plan Voisin, 1925

Em propostas posteriores de intervenção urbana, o arquiteto elabora a inserção da via expressa com maior atenção ao contexto, sem, no entanto, desistir da solução em via elevada. Partindo da exaltação ao projeto da fábrica da Fiat em Turim ${ }^{69}$, Le Corbusier lança mão do conceito de edifício-viaduto para intervir na cidade existente. Tais propostas são elaboradas pela primeira vez ao longo de sua primeira viagem sul-americana, onde verdadeiros edifícios contínuos são construídos sob as estruturas de vias elevadas, como aquedutos ou pontes ferroviárias, numa interação entre a topografia natural e o engenho humano. O "arranha-terra" de São Paulo e o "arranha-mar" da cidade costeira de Montevidéu são exemplos desse conceito. A rodovia reta e inabalável mantém sua cota elevada e constante, enquanto que o espaço entre o tabuleiro e o terreno seria ocupado com construções. No caso paulistano, o trecho rodoviário na área central é construído sobre conjuntos comerciais, enquanto que ao longo de seu afastamento a construção daria lugar a unidades habitacionais. Rampas laterais são responsáveis pelos acessos ao estacionamento sob a pista e aos retornos elevados. Já as relações entre a rodovia e o tecido urbano tradicional se dão nos momentos onde a topografia da cidade encontra a cota da rodovia. Trata-se de uma proposta que opõe a ordem da rodovia à desordem da cidade tradicional, como afirma o autor: "o prefeito de São Paulo me disse: estamos perdidos, não sabemos mais como intervir na desordem da cidade. Resposta: aqui está a ordem"70, responde o arquiteto. "Vocês estão completamente impedidos por seus vales e colinas. Vocês não podem mais atravessas a vossa cidade, drenar a vossa circulação? Então façam-no pelo alto, por baixo, no ar sobre a cidade onde vocês são livres" ${ }^{71}$. 


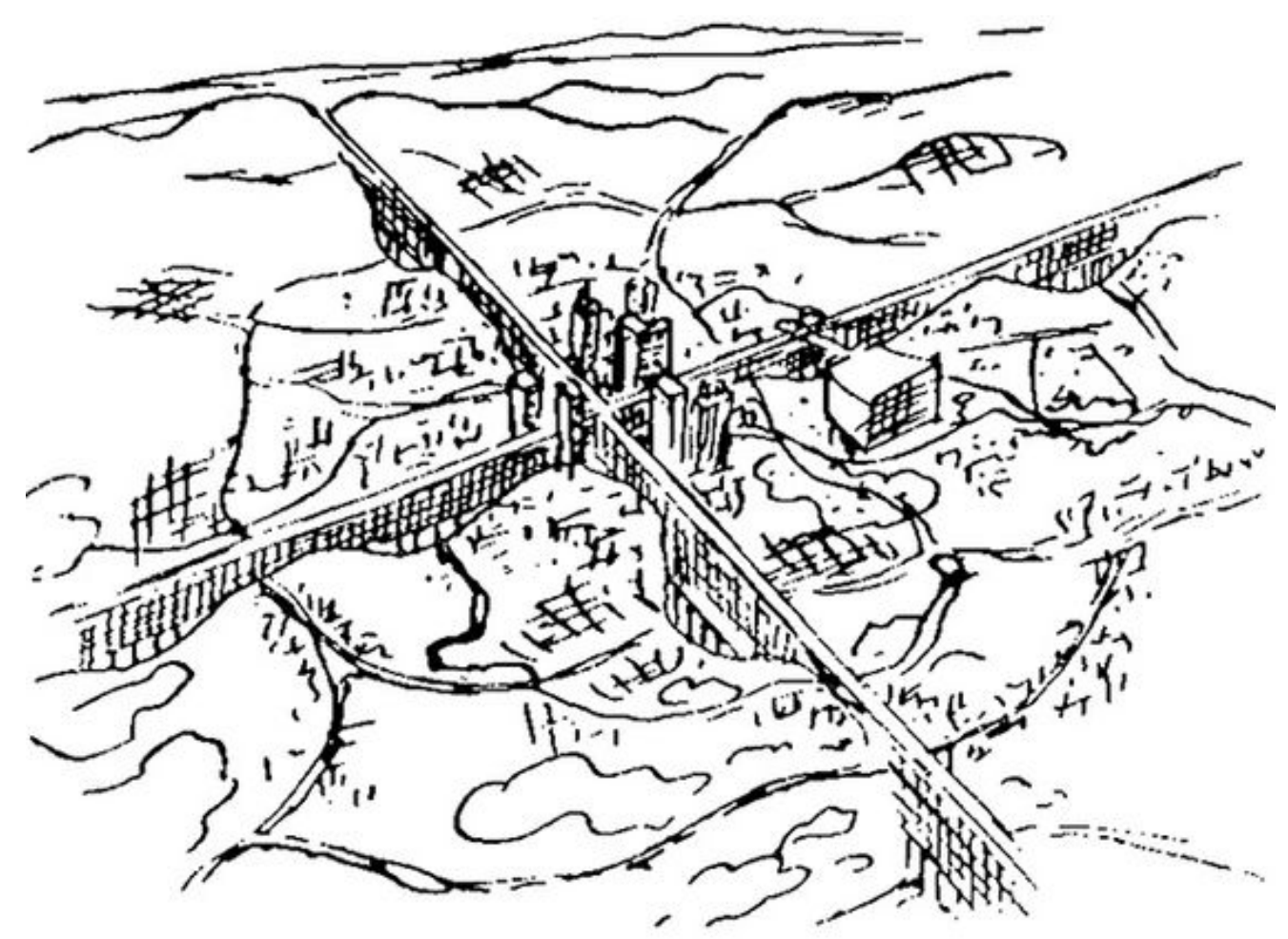

Figura 33 | Le Corbusier - Proposta para São Paulo, 1929

Já o edifício viaduto imaginado para o Rio de Janeiro marca uma inflexão no pensamento estético do arquiteto, onde discurso tão apegado à linha reta não persistiria por muito tempo. De acordo com Cabral: "Le Corbusier parece mitigar seu radical amor pelas vias retas, considerando-as adequadas para o lazer e contato com a natureza. Após a experiência carioca de 1929 e a 'descoberta' do meandro, finalmente as liberta: 'As ruas serão o que quiserem, retas ou curvas. São rios, grandes rios ramificados seguindo sua aritmética exata'"72. Além disso, a intervenção aérea e mais pontual poderia até deixar intacta a cidade existente $^{73}$. A proposta para a cidade de Argel dá continuidade às curvas do plano carioca, porém desenvolvido mais detalhadamente. Não era necessário apelar à linha reta para que a estrada se sobressaísse em contrastante com a natureza, onde a construção racional geométrica se sobrepõe às peculiaridades do terreno e da paisagem natural: "uma estrada não é uma entidade quilométrica; ela é um evento de plástico em meio à natureza. Geometria e Natureza foram muitas vezes o apoio de coisas emocionantes" ${ }^{74}$.

Para Ziegler, a proposta do edifício-viaduto parte também de motivações econômicas, criando um modelo de urbanização racional. A ocupação da estrutura sob os viadutos com propriedades de uso comercial e residencial era encarada como forma de criação de solo urbano. Ao invés de valorizar as margens de uma rodovia colada ao chão, o arranha-terra cria valor imobiliário sob a rodovia. Logo, a comercialização desses espaços financiaria a construção da infraestrutura ${ }^{75}$ :

74 "une route n'est pas qu'une entité kilometrique; elle est un événement plastique au sein de la nature. Géometrie et nature ont été souvent le support de choses émouvantes». Le Corbusier, Apud. ZIEGLER: p. 110. 75 ZIEGLER, 1998: p. 111. 
"Le Corbusier reúne, dessa forma, considerações técnicas, econômicas e estéticas em um sistema projetual que se materializa no edifício-viaduto. Ele associa, de um modo original, as funções de circular e de habitar, seguindo um método paisagístico que se baseia em um ato fundador, o estabelecimento de uma infraestrutura rodoviária."it

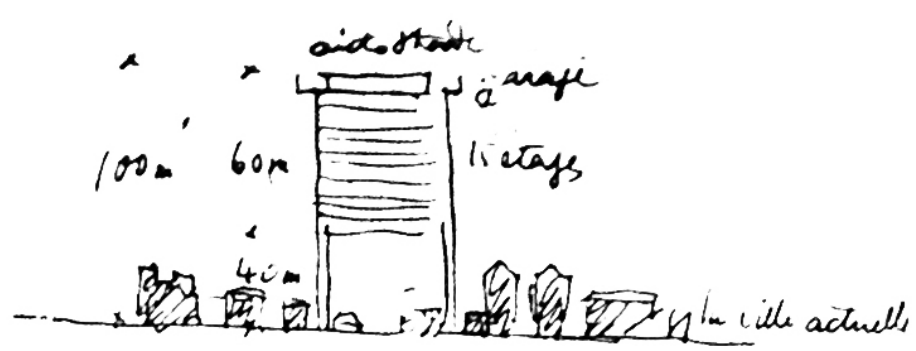

Le viaduc autostrade cote $100 \mathrm{~m}$., jeté

par-dessus la ville, de colline à colline.

Figura 34 | Le Corbusier - Proposta do "Arranha-Terra" para São Paulo, 1929: "O viaduto autoestrada, a $100 \mathrm{~m}$ de altura, lançado por cima da cidade, de colina a colina"

\section{A UTOPIA DO LOBBY AUTOMOBILISTICO}

Para que os Estados Unidos pudessem rumar definitivamente à "era do automóvel," o lobby automobilístico precisava convencer a opinião pública da necessidade de transformar o espaço urbano para que o automóvel fosse acessível a todos. Para isso, era necessário investir em aparato ideológico capaz de convencer a população norte-americana, não apenas da necessidade de transformação do espaço urbano, mas engajá-la no desejo de uma vida suburbana, possível graças ao transporte individual motorizado.

Partindo das visões urbanísticas de visionários como Corbett e Le Corbusier, aliadas às mais modernas tecnologias de projeto de rodovias, o lobby automobilístico produziu seu próprio manifesto, baseado no discurso de oposição entre a densa e problemática cidade tradicional norte-americana e a visão perfeita de uma nova cidade, onde um futuro melhor era possível através do progresso tecnológico, tendo como protagonista o maior símbolo de modernidade: o automóvel.

Em 1937, Miller McClintock - o porta-voz intelectual do lobby automobilístico - empreendeu uma espécie de espetáculo da via expressa financiado pela Shell Oil Company. Ele combinou sua expertise em projetos rodoviários com as habilidades do talentoso cenógrafo Norman Bel Geddes, e juntos construíram um modelo em escala do que seria "a cidade automotiva de amanhã" ${ }^{77}$. Feito para ser fotografado, o modelo seria visto por milhões de pessoas através de shows de slides em diversas cidades americanas. "As cidades norte-americanas serão reconstruídas nos próximos vinte e cinco, cinquenta anos," afirmava Mc Clintock em suas apresentações ${ }^{78}$. Segundo Norton, o jornal

"The New York Times" descreveu a visão apresentada, dotada de calçadas elevadas exclusivas 
para pedestres como uma "cidade do futuro onde o pedestre pode andar sem medo de morrer subitamente e o motorista não terá problemas para estacionar" ${ }^{\prime 79}$. Promovido como anúncio em revistas e jornais, a Shell denominava o projeto como a "Cidade do Amanhã":

“Em 1960, o tráfego expresso irá acelerar em 50 milhas por hora em bulevares de alta velocidade, alcançados por rampas a cada dez quarteirões. Sem semáforos... sem intersecções." ${ }^{80}$
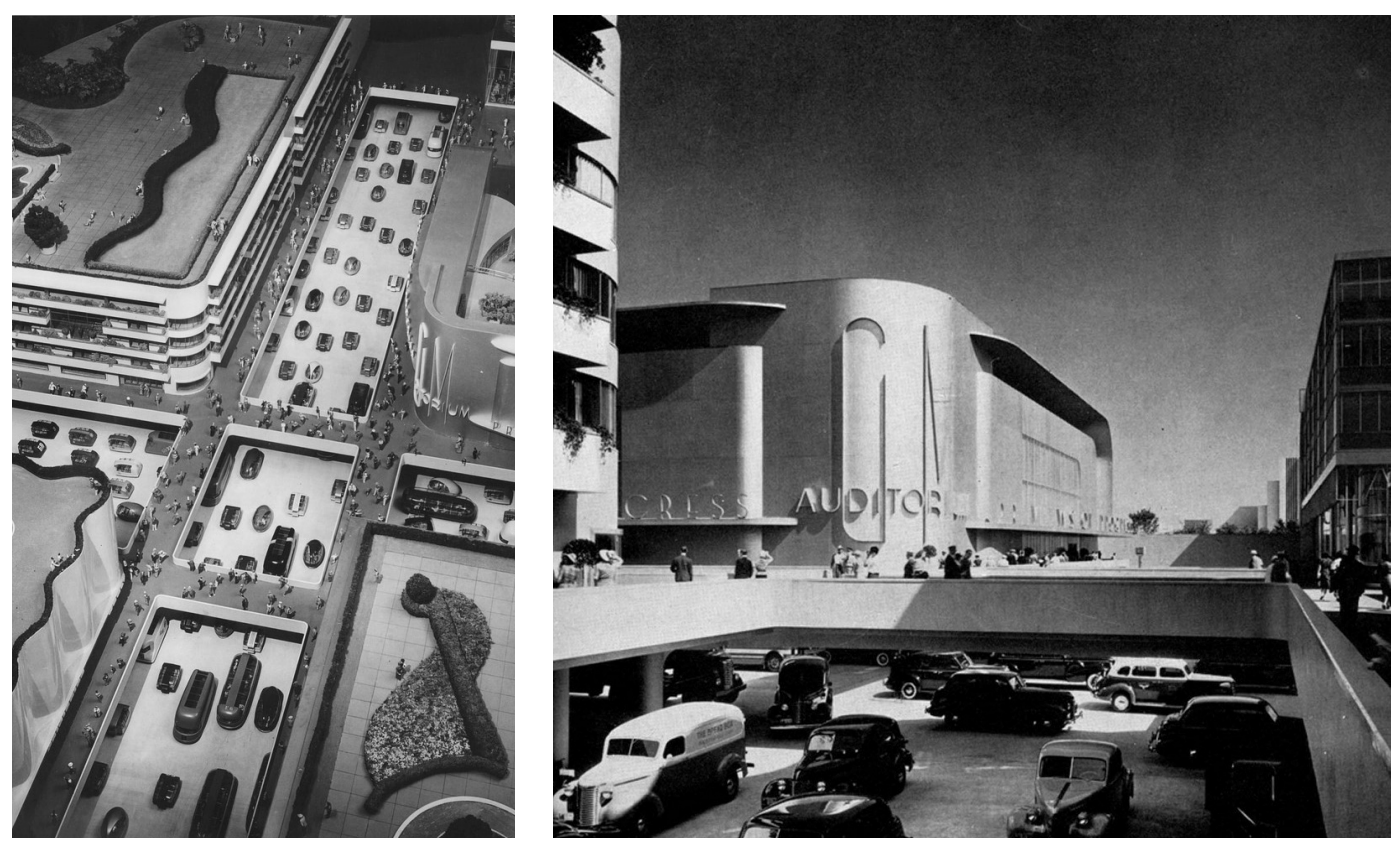

Figura 35 | Norman Bell Guedes - Futurama, 1939. O centro da cidade do futuro

O show desenhado por Geddes atingiu enormes proporções de divulgação ${ }^{81}$ ao ser exposto com o nome de Futurama na Feira Mundial de 1939, organizada na cidade de Nova lorque pelo interventor Robert Moses. A feira, intitulada "Construindo o mundo de amanhã", celebrava a indústria e a tecnologia modernas através da representação de diversos setores da indústria, com conteúdo essencialmente propagandístico. Através do financiamento da General Motors, a visão concebida por McClintock e Geddes ganhou novas proporções, expandindo o modelo em uma área gigantesca, a ser apresentado em uma sala fechada que simulava a visão a partir da janela de um avião. De cima, o visitante observava o grande modelo, enquanto um narrador descrevia as maravilhas de uma cidade futura genérica no não-tão-distante ano de 1960, onde modernas rodovias permitiriam a condução de seus veículos a cento e vinte - ou até cento e sessenta - quilômetros por hora ${ }^{82}$. Nas palavras de Geddes:

79 "city of the future where the pedestrian can walk without fear of sudden death and the motorist can always find a parking space." NORTON, 2008: p. 249.

80 "you'll breeze right over cross-town traffic." "By 1960, express traffic will speed along at 50 miles an hour over high-speed boulevards, reached by ramps every ten blocks. No stop lights... no intersections." Apud. NORTON, 2008: p. 249.

81 No primeiro verão da exposição, ela havia sido visitada por cinco milhões de pessoas, (NORTON, 2008: p. 250), chegando a quase dez milhões durante toda a feira. DIMENTO; ELLIS, 2014: p.51.

82 NORTON, 2008: p. 250. 
"Futurama é um modelo em grande escala que representa quase todos os tipos de terreno na América e ilustra como um sistema de auto-estrada pode ser estabelecido em todo o país - através das montanhas, sobre rios e lagos, cidades - nunca desviando de seu trajeto direto e sempre aderindo aos quatro princípios básicos do projeto rodoviário: segurança, conforto, velocidade e economia." ${ }^{83}$

O projeto lança mão em diversos momentos de diferentes estratégias de segregação. O desenho das áreas centrais faz evidente referência ao projeto de Corbett - com suas passarelas elevadas para pedestres no lugar de calçadas -, privilegiando a segregação do pedestre nos centros urbanos tradicionais como forma de garantir sua segurança. Ao mesmo tempo, os automóveis tomariam o antigo lugar das calçadas em ruas de apenas um sentido, organizadas em uma malha ortogonal. Veículos seriam estacionados no interior dos edifícios, mantendo o espaço das ruas exclusivo para circulação. Sobre a malha de ruas de tráfego local se sobrepõe uma malha de vias expressas a cada dez quadras, permitindo maiores velocidades de deslocamento. DiMento e Ellis veem em Futurama semelhanças com as propostas urbanas de Le Corbusier, onde a unidade mínima de urbanização seria uma quadra livre para pedestres, ocupada por edifícios de apenas cinco andares. No entanto, intervalos de dez quadras seriam pontuados por enormes arranha-céus que tomam emprestado dos automóveis o design aerodinâmico, colaborando com o ar futurista da proposta.
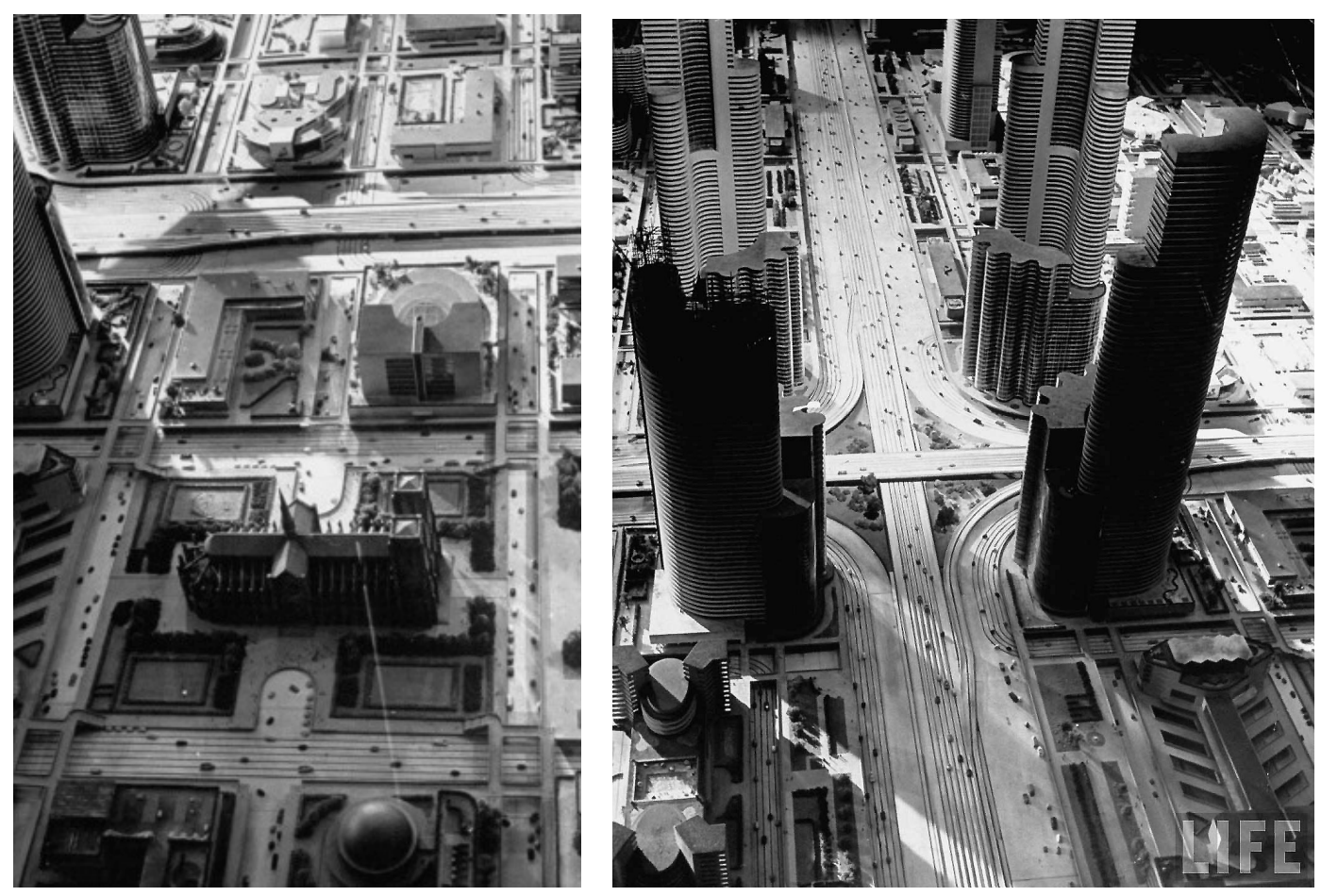

Figura 36 | Norman Bell Guedes - Futurama, 1939

83 "Futurama is a large-scale model representing almost every type of terrain in America and illustrating how a motorway system may be laid down over the entire country-across mountains, over rivers and lakes, through cities and past towns-never deviating from a direct course and always adhering to the four basic principles of highway design: safety, comfort, speed and economy." GEDDES Apud. DIMENTO e ELLIS, 2014: p. 50. 
Já as áreas mais afastadas eram marcadas por largas vias expressas com incontáveis faixas de rolamento, determinadas por um traçado absolutamente objetivo, em linha reta. A utopia do lobby automobilístico se destaca das principais obras de vias expressas urbanas construídas nos Estados Unidos até então, que tinham como principal expoente as parkways de duas faixas de rolamento, com traçado sinuoso e contemplativo. Diferentemente da maioria dos planejadores de rodovias da época, Bel Geddes não apoiava a construção de rodovias inter-regionais que penetrassem no tecido urbano da cidade tradicional, tampouco apoiava o conceito de uma via expressa perimetral ao redor do centro. Para ele, as rodovias de grandes distâncias deveriam manter seu traçado em linha reta, conectando-se aos centros urbanos através de vias alimentadoras. Porém, mesmo essas vias alimentadoras seriam vias expressas de acesso limitado que penetrariam nos centros urbanos, como fica claro no modelo de Futurama.

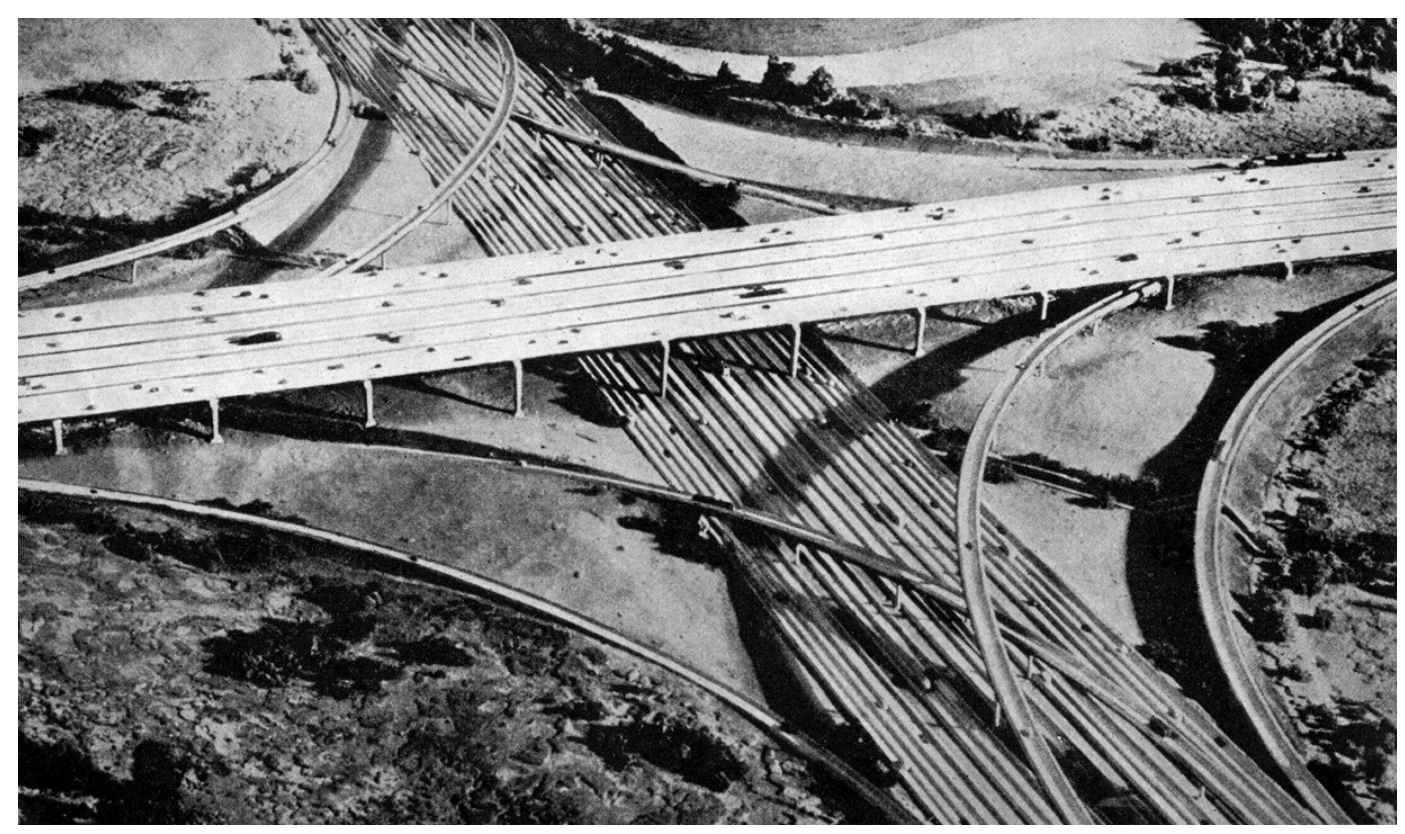

Figura 37 | Norman Bell Guedes - Futurama, 1939 


\subsection{VIAS EXPRESSAS URBANAS: CATALIZADORES DO URBANISMO FUTURO NORTE-AMERICANO}

Podemos afirmar que nos Estados Unidos a partir da década de 1930, para diversos dos agentes envolvidos na questão urbana - tanto para profissionais do lobby automobilístico, engenheiros, planejadores e arquitetos quanto para a opinião pública - era necessário, de alguma forma transformar o espaço de circulação das cidades. Antes que em qualquer outro local do planeta, os centros urbanos não suportavam mais automóveis; congestionamentos e acidentes estavam maiores do que nunca. É a partir desse momento que as cidades norte-americanas dão início a um radical processo de transformação, preparando as bases para se tornar posteriormente as "cidades do automóvel." Como colocou Miller McClintock, "a cidade do amanhã será uma cidade automotiva" 84 .

A solução encontrada por engenheiros de rodovia para o problema do trânsito diferentemente do que propunham os engenheiros de tráfego - não passava pelas medidas mitigatórias de regulamentação, mas pelo investimento em infraestrutura rodoviária, em forma de via expressa com acesso limitado. Trazia-se para o espaço urbano elementos do repertório das rodovias da área rural. Como afirmou Alvan Macauley, presidente da Packard Motor Company em 1929: "as rodovias rurais podem contribuir muito com o alívio das ruas das cidades" ${ }^{85}$. Buscavam ganho de velocidade de circulação como forma de aumentar a fluidez do trânsito.

Detroit - também conhecida como The Motor City ${ }^{86}$ - promoveu o que se considera como o primeiro plano abrangente de rodovias urbanas. O Superhighway Plan for Greater Detroit, de 1923, pretendia construir uma rede de trezentos e sessenta quilômetros de infraestrutura de transporte, comportando vias artérias com os principais cruzamentos em desnível e acessos restritos, associados a um sistema de transporte público sobre trilhos. Nas palavras de Daniel Turner, responsável pelo plano:

"A Super-Highway é única. Trata-se de uma partida nova e necessária no planejamento de transporte para a cidade moderna. Ela não apenas prevê uma forma mais barata de transporte coletivo sobre trilhos e de tráfego rodoviário comum (...), mas também fará algo nunca antes proposto - ela irá fornecer uma rodovia expressa de tráfego motorizado sobre a qual os automóveis podem viajar continuamente em velocidade máxima com segurança, porque todos os cruzamentos em nível serão

\footnotetext{
84 "The city of tomorrow will be an automotive city. - Miller McClintock, 1937." NORTON, 2008 : p. 256.

85 "the country highways can do much to relieve city streets" Ibid.: p. 202.

86 A cidade se tornado a principal cidade americana fabricante de automóveis, ganhando o apelido de cidade do motor.
} 
eliminados. Em outras palavras, a Super-Highway se tornará a principal artéria de trânsito da cidade futura, tanto para trens ferroviários quanto para automóveis." ${ }^{87}$.

No entanto, muito do que foi proposto para Detroit acabou não saindo do papel. Assim como outros planos publicados até a década de 1940, como o plano de Chicago realizado por McClintock de 1928, dificuldades de financiamento dos projetos não permitiram sua construção ${ }^{88}$. Mesmo assim algumas das vias propostas acabaram sendo implementadas, como a Woodward Avenue, concluída em 1928. Ela possuía duas pistas de concreto separadas por um canteiro central dotado de trilhos, utilizado por uma linha de bondes elétricos. Como nas vias expressas atuais, cruzamentos entre vias eram realizados em desnível para garantir a fluidez necessária ao tráfego. Contudo, não é possível considerá-la uma via expressa de acesso limitado como concebemos hoje, pois suas pistas não estavam segregadas das atividades urbanas circundantes, e tampouco existiam vias locais paralelas que fizessem esse paapel, com acessos de aceleração e desaceleração. Em certa medida, tratava-se de uma rodovia comum, porém dotada de cruzamentos em desnível.

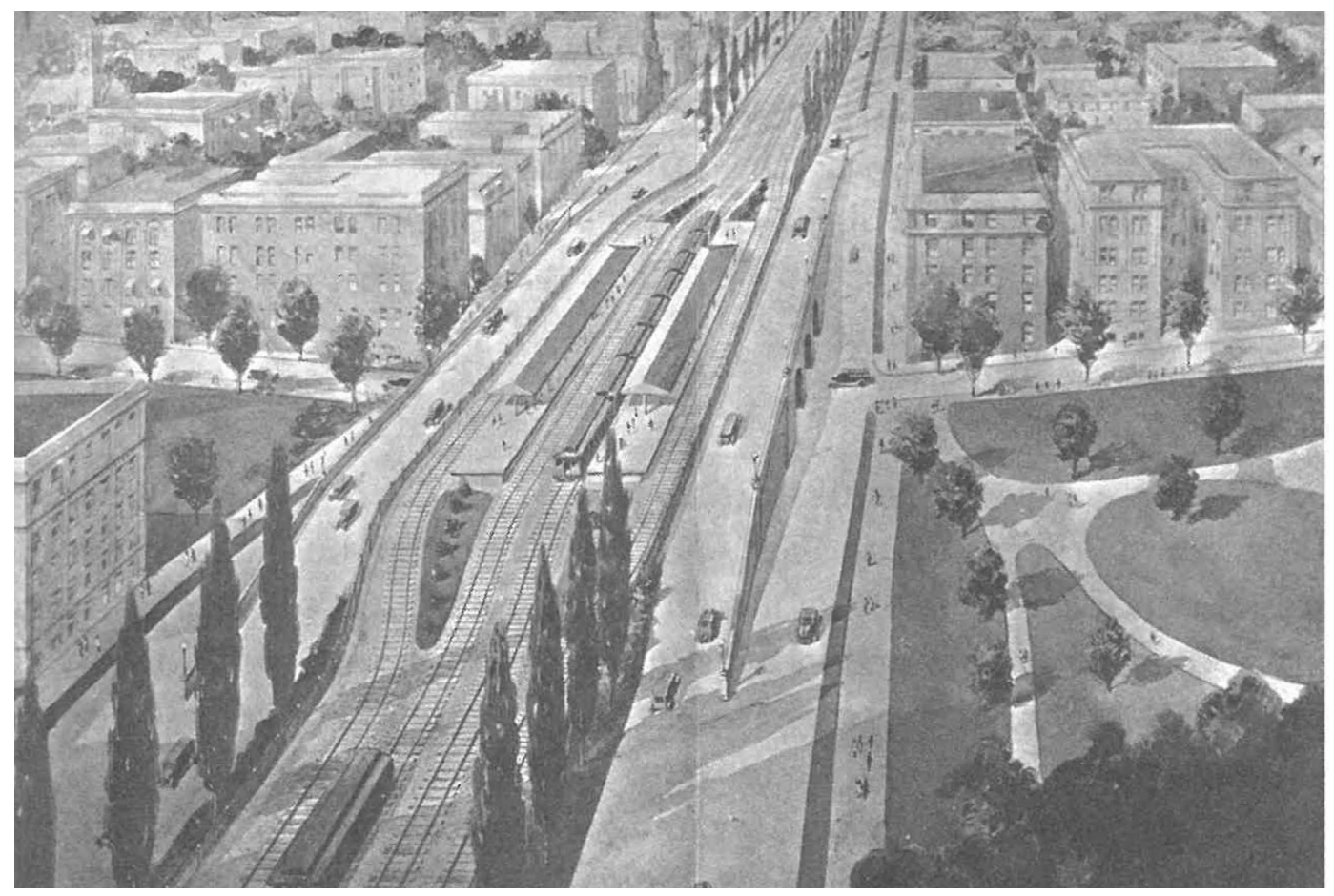

Figura 38 | Detroit Rapid Transit Commission - Detroit Superhighway System, 1924

87 "The Super-Highway is unique. It is a new and necessary departure in transportation planning for the modern city. Not only does it provide for a cheaper form of rapid transit on rails and for the ordinary highway motor-traffic of today, but it will also do something never before proposed -it will furnish an express motor traffic highway upon which automobiles can travel continuously at a maximum speed with safety, because all grade crossings will be eliminated. In other words, the Super-Highway will become the major traffic artery of the future city, for both rail and automobile rapid transit services" Apud. BROWN, 2005: p. 10.

88 O problema do financiamento da infraestrutura rodoviária nos Estados Unidos só foi resolvido com verbas federais. (BROWN, 2005; NORTON, 2008; DIMENTO; ELLIS, 2014) 
Outros projetos como este já haviam sido concebidos em anos anteriores, mas sofriam da mesma dificuldade de viabilização por questões financeiras. Com o início da taxação da gasolina na segunda metade da década de 1920, uma quantidade significativa de recursos se tornou disponível para o investimento em infraestrutura rodoviária. Além disso, como forma de geração de empregos, a política do New Deal, na década de 1930, passou a direcionar investimentos federais para grandes obras de infraestrutura.

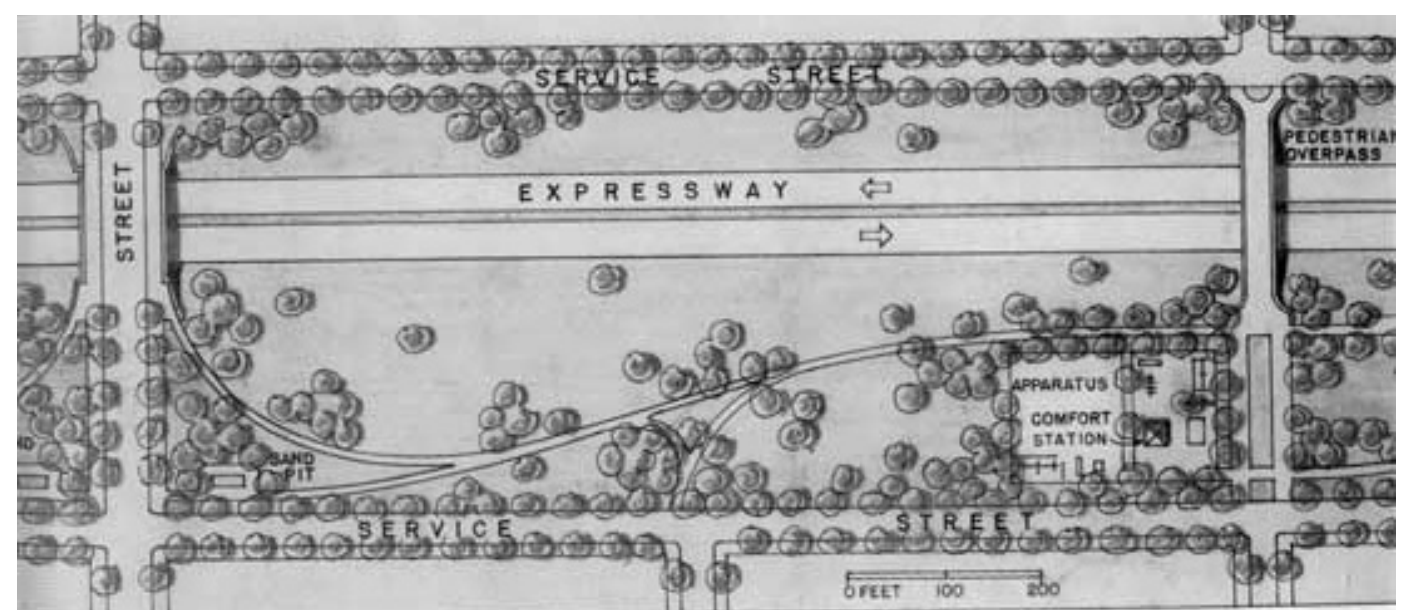

Figura 39 | Detroit Rapid Transit Commission - Detroit Superhighway System, 1924

As avenidas precisavam ser transformadas em canais exclusivos de circulação de veículos motorizados, segregados do restante das atividades urbanas. Eles não seriam interrompidos por intersecções em nível, sendo acessíveis apenas após longos intervalos, através de alças de aceleração e desaceleração. As curvas passariam a ser desenhadas com inclinação transversal, permitindo ao motorista seguir o percurso sem reduzir sua velocidade. Também era preciso garantir que nenhuma propriedade ao longo da avenida tivesse acesso direto às suas pistas, e sobretudo, as novas avenidas não poderiam sofrer a interferência de pedestres. Norton destaca de um relatório de 1933 a descrição de novas "rodovias expressas" urbanas como uma aplicação de "novos princípios de planejamento rodoviário", definidas como "'vias limitadas' para uso exclusivo do tráfego motorizado" ${ }^{89}$ nas cidades. Aos poucos, tais vias passariam a fazer parte do repertório urbano.

Poucos meses após a publicação de Townless Highways, em 1930, o advogado Edward M. Bassett - considerado o "pai do zoneamento americano" - publica artigo apontando para mesma direção, porém focando-se nas avenidas urbanas. Para ele, obras de cruzamento em desnível eram importantes para a melhora do tráfego, mas as interferências provocadas por outras atividades existentes nas ruas - como estacionamentos, lojas, garagens e postos de combustível - eram prejudiciais à fluidez do tráfego ${ }^{90}$. Era necessário um novo tipo de avenida, afirmava Bassett: "um novo tipo de avenida - um que seja como uma rodovia para ambos veículos de lazer e de negócios, mas que seja como uma parkway na prevenção da

89 "express highways"; "new principles of highway planning"; "the new roads were 'limited ways' for the exclusive use of motor traffic."NORTON, 2008: p. 204.

90 SWIFT, 2011: p. 122. O autor cita Bassett: "Even if important grade crossings are eliminated, the driveways, gasoline stations, garages, stores and parked cars cause great limitation." 
ocupação desordenada de suas margens" ${ }^{91}$. A essa nova tipologia urbana Bassett dava o nome de freeway. Segundo seu autor, o nome conotava "em curto e bom anglo-saxão" a "liberdade dos cruzamentos em desnível e de acessos viários privados, lojas e fábricas" 92. Mais do que um simples nome, a ideia do trânsito em "liberdade" ao longo do espaço urbano congestionado significava a entrada do ideal individualista - materializado pelo automóvel e pela rodovia rural - dentro da esfera urbana.

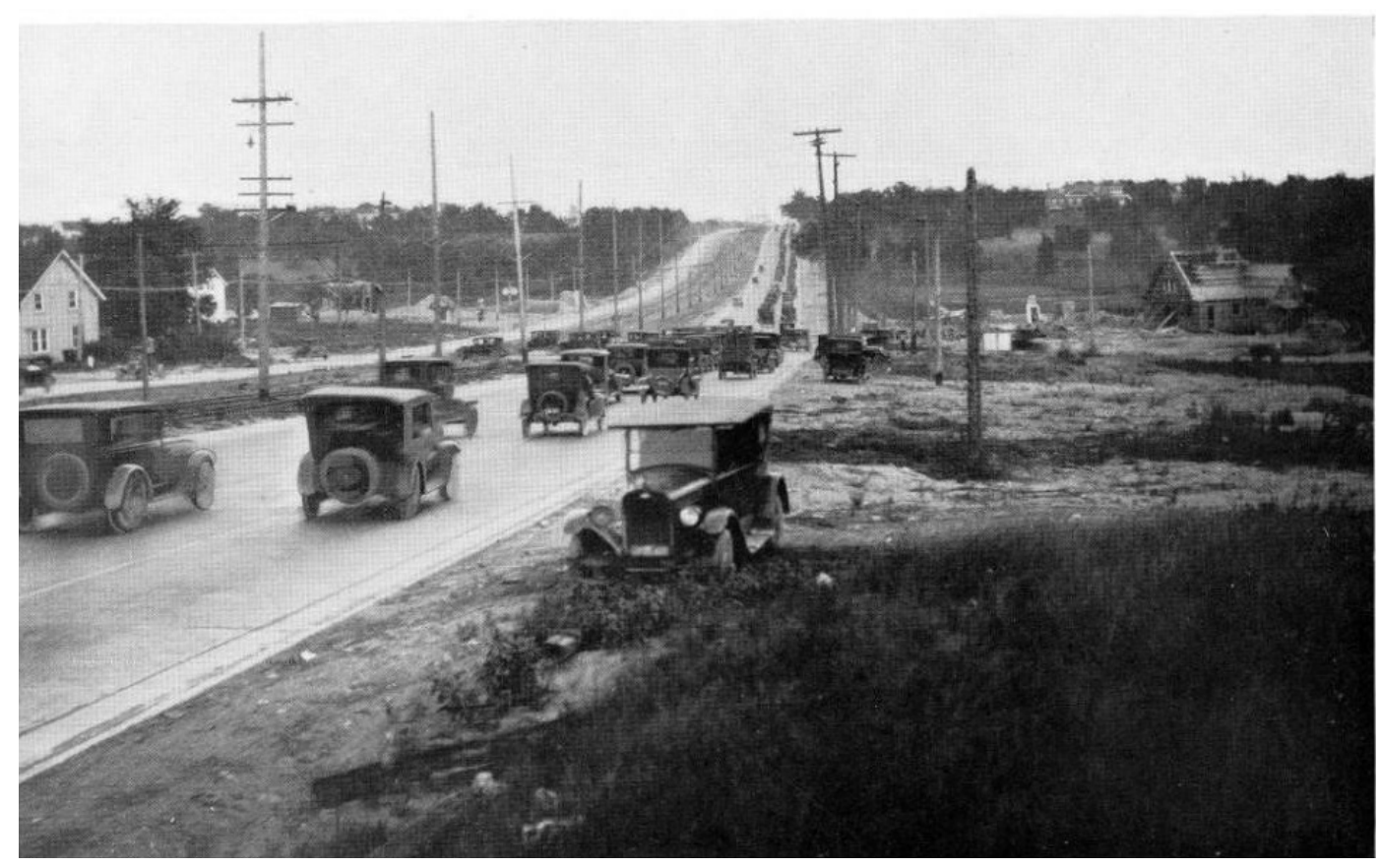

Figura 40 | Woodward Avenue, Detroit

Miller McClintock também contribuiu no mesmo período para o desenvolvimento da via expressa. As pesquisas no Erskine Bureau da Universidade de Harvard levaram-no ao desenvolvimento de sua "teoria da fricção" ${ }^{93}$. Para ele, o trânsito se comportava como um fluido, correndo no sistema viário como as águas de um rio, ou o sangue através das veias, sujeitas a obstáculos e diferenças de vazão. Desse modo, o grau de fluidez do tráfego estava sujeito a quatro formas de "fricção" - também relacionadas a acidentes de trânsito. Cruzamentos entre ruas produziam "fricção interseccional", responsável - segundo o pesquisador - por um em cada cinco acidentes. A "fricção do fluxo interno", causada pela interação dos automóveis no sistema viário, seria responsável por mais de $40 \%$ dos acidentes. Já a "friç̧ão medial" relacionava fluxos em sentidos opostos, causando também cerca de um quinto dos acidentes. Por fim a "fricção marginal" - responsável pelo restante dos acidentes - era resultado de interferências externas à rodovia, como elementos na calçada, pontes, edifícios e até pedestres na calçada ${ }^{94}$.

91 "a new kind of thoroughfare - one which will be like a highway for both pleasure and business vehicles, but which will be like a parkway in preventing the cluttering-up of its edges." Apud. SWIFT, 2011: p. 122.

92 "short and good Anglo-Saxon"; "freedom from grade intersections and from private entrance ways, stores and factories." Ibid.: p. 122.

93 "Friction Theory." Ibid.: p. 123.

94 Ibid.: p. 123-4. 
A redução ou eliminação dessas fricções seria possível através de um redesenho do espaço viário a partir das necessidades do trânsito. A diminuição das fricções no trânsito permitiria um aumento de velocidade dos automóveis, provocando uma significativa melhora do trânsito. McClintock batizou o que seriam essas novas vias de limited way, marcadas por quatro atributos que preveniriam grande parte dos acidentes de trânsito. Uma ilha central, ou mesmo a separação entre sentidos de tráfego através de elementos construídos, eliminariam a friç̧ão medial. Cruzamentos em desnível eliminariam a fricção interseccional. Eliminando-se o acesso direto à rodovia, seja de veículos ou pessoas, acabaria com a fricção marginal. Por fim, rampas de aceleração e desaceleração para entrada e saída na rodovia poderiam reduzir a fricção do fluxo interno. ${ }^{95}$

A visão de via expressa de McClintock era urbana: "a via limitada - conforme ele a chamava - deve ser construída bem no coração de qualquer cidade", mesmo nas "partes mais densas de áreas urbanas", onde poderiam oferecer "uma operação mais segura e rápida", quando comparadas às vias rurais. Essas novas avenidas trariam a era do automóvel para as cidades americanas, uma "era completamente nova de transporte automobilístico em centros metropolitanos" ${ }^{96}$.

Posteriormente aos artigos de McKaye, Bassett e McClintock, outros pensadores colaboraram através de artigos com o desenvolvimento do conceito da via expressa urbana norte-americana. Para o planejador nova-iorquino Robert Whitten, por exemplo, a via expressa não precisaria estar isolada da cidade para funcionar. A possibilidade de construí-la em trincheira ou elevada do nível da rua permitiria que as vias expressas penetrassem no interior da cidade. Ambas as soluções, segundo seu autor "provariam ser úteis na promoção da eficiência do tráfego, redução de ruídos, beleza e amenidade" ${ }^{97}$. Na mesma época, o austríaco radicado nos Estados Unidos Fritz Malcher concebia seu sistema de circulação contínuo, intitulado "Steadyflow System," onde permitia-se ao automóvel circular ao longo da cidade sem interferências, como em uma via expressa de acesso limitado.

"Imagine uma cidade onde o seu sistema viário permite que os veículos se movam sem obstruções, semáforos ou guardas de trânsito, com regulação automática de velocidade e capacidade, onde os pedestres podem caminhar continuamente por toda a área da cidade - não importa se está nos arredores ou na Centro - sem nenhum medo e perigo do tráfego de veículos... como um ideal de cidade que podemos tornar realidade"198

Nesse mesmo período as estradas norte-americanas começavam a apontar para sérios problemas de manutenção e obsolescência tecnológica. Conforme aumentava a velocidade máxima alcançada pelos automóveis, os antigos raios mínimos de curvatura tornavam-nas

95 SWIFT, 2011: p. 124.

96 "A limited way may be constructed right to the heart of any city," "densest parts of urban areas,"; "provide safer and higher speed operation"; "an entirely new era in automobile transportation in metropolitan centers." NORTON, 2008: p. 240-1.

97 "prove helpful in promoting traffic efficiency, noise reduction, beauty and amenity". Apud. SWIFT, 2011: p. 124.

98 "Imagine a city where the street system permits vehicles to move without obstructions, traffic lights or officers, with automatic regulation of speed and capa city, where pedestrians can walk continuously through the whole city area - no matter whether this be in the outskirts or in the center - without any fear and danger of vehicular traffic... such a city ideal we can make come true." MALCHER Apud. SWIFT, 2011: p. 122 
cada vez mais perigosas e o asfalto das antigas rodovias não era capaz de comportar o aumento do peso dos veículos que nela trafegavam, danificando sua superfície ${ }^{99}$. O investimento em rodovias se mostrava necessário, mas a quantidade de recursos disponíveis para a construção de novas estradas e manutenção das antigas não correspondia à altura. Desse modo, o Bureau of Public Roads realizou um inventário das rodovias norte-americanas, de modo a priorizar os investimentos onde eles mais fossem necessários. Após a análise dos resultados obtidos pela pesquisa, chegou-se à conclusão de que os trechos rodoviários urbanos eram os locais que mais necessitavam de investimentos. O tráfego rodoviário "que se movimenta em grande volume entrando e saindo das cidades" diminui "para proporções muito menores como cidades são deixadas para trás" ${ }^{100}$. A partir dos resultados da pesquisa, investimentos federais passaram a ser realizados nas cidades e rodovias urbanas passam a ser construídas como solução para o crescente problema do trânsito ${ }^{101}$. No entanto, o Bureau não possuía experiência no âmbito de projetos em cidades, trazendo para a cidade sua experiência com projetos em áreas rurais ${ }^{102}$. Enquanto os obstáculos que os engenheiros rodoviários conheciam eram essencialmente naturais, os empecilhos urbanos eram sobretudo estruturas pensadas pelo homem. A partir da necessidade de solucionar 0 problema do trânsito nas áreas centrais, engenheiros de rodovia passaram a projetar suas primeiras intervenções dentro do tecido urbano da cidade tradicional.

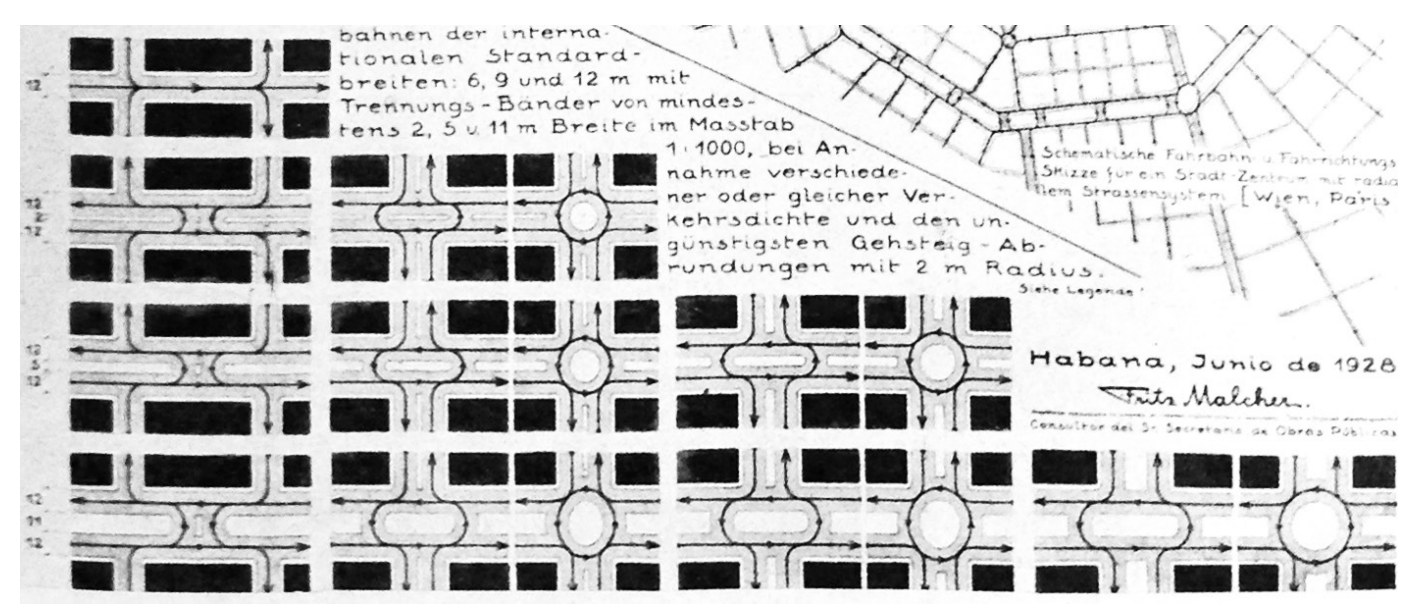

Figura 41 | Plano de Fritz Malcher para Havana, 1928

Apesar da iniciativa de construção de vias segregadas ter sido motivada por conta do problema do trânsito, elas também foram apontadas como solução para a redução de fatalidades. Ao separar os pedestres dos automóveis a velocidade deixaria de ser uma ameaça às pessoas, ao mesmo tempo que motoristas teriam garantido seu direito de acelerar. Norton nos traz uma citação do engenheiro William Cox, defendendo a segregação do trânsito em relação aos pedestres como solução de segurança: “Não devemos ter dúvidas que veremos o trânsito de automóveis mais e mais coletado em grandes vias arteriais, de onde o pedestre será excluído, estando sobre ou sob a via, e

99 SWIFT, 2011: p. 127-8

100 "traffic that moves in great volume into and out of cities, but dwindles to much smaller proportions as cities are left behind" Ibid.: p. 129.

101 DIMENTO; ELLIS, 2014: p. 24.

102 Ibid.: p. 25. 
sendo impedido de brincar e 'errar' pela rodovia" ${ }^{103}$. Outro engenheiro citado por Norton afirma que "a provisão de rotas separadas para o tráfego em alta velocidade eliminará todas as causas de acidentes em pedestres e crianças porque pedestres não serão permitidos nas 'super-rodovias'"104.

Ademais, não apenas a segregação reduzia os riscos da via expressa, mas seu desenho também permitia conduzir em velocidade com segurança. De acordo com Norton, foi a partir da década de 1920 que membros do lobby automobilístico passaram a apontar alterações no desenho da rua como uma forma de evitar acidentes. Ele menciona uma afirmação do Clube do Automóvel de Cleveland, especulando que uma possível maneira de evitar acidentes seria "fornecer ruas onde veículos podem viajar em uma boa taxa de velocidade com o máximo elemento de segurança para outros motoristas e pedestres". Outros apontavam cruzamentos em desnível como solução para a diminuição de acidentes ${ }^{105}$. Conforme os projetos rodoviários evoluíam, a questão da segurança do motorista passou a entrar na pauta dos lobbistas na defesa das vias expressas urbanas. Vias desenhadas exclusivamente para automóveis possuíam características que facilitavam a condução do veículo, sem exigir da habilidade dos motoristas. McClintock afirmou que seu objetivo era conceber a "rodovia à prova de idiotas, construída de tal forma que acidentes se tornassem impossíveis"106. Para ele, "o motorista deve ser limitado externamente de se matar" 107 na rodovia, permitindo que o público pudesse viajar ao mesmo tempo em velocidade e segurança.

No entanto, os resultados das primeiras vias expressas urbanas foram desastrosos, pois ao incentivar o motorista a acelerar, exageros eram muito frequentes. Nos casos onde havia uma única pista, sem divisão entre os sentidos, colisões frontais eram recorrentes. Como resultado dessas primeiras experiências o desenho das vias expressas foi aprimorado, tornando imprescindível a separação da via em duas pistas, uma para cada sentido.

Diferentes das estruturas construídas a partir da década de 1950, as primeiras vias expressas urbanas eram significativamente menores, em sua maioria com apenas duas faixas de rolamento por sentido, separadas por áreas verdes. Tais vias faziam parte da estrutura viária da cidade existente, como se fossem vias arteriais mais eficientes; são propostas que buscam aliar as novas tecnologias de trânsito ao repertório do tecido urbano tradicional ${ }^{108}$. A velocidade máxima das novas vias não passava dos $70 \mathrm{Km} / \mathrm{h}$ e os elementos de conexão e cruzamento em desnível eram mais compactos, ocupando o espaço urbano de forma mais racional. Além disso, as freeways faziam parte de planos mais abrangentes, que as relacionavam com questões de zoneamento e uso do solo, estando integradas também com soluções de transporte público,

103 "we shall no doubt see automobile traffic (...) more and more collected in great arterial ways, from which the pedestrian will be excluded, being overpassed or underpassed, and being kept from playing or wandering in the roadway." NORTON, 2008: p. 236.

104 "the provision of separate routes for high speed traffic will eliminate all of accidents to pedestrians and children because pedestrians will not be permitted on the superhighways." NORTON, 2008: p. 238-9.

105 "provide streets on which vehicles can travel at a good rate of speed with the maximum element of safety for other drivers and for pedestrians." Ibid.: p. 236. Norton também menciona a existente preocupação com a construção de caminhos e passarelas para pedestres. Porém, tais elementos não eram implementados com tanta frequência.

106 "fool-proof highway, the motor thoroughfare built in such a way that accidents will be impossible."

Ibid.: p. 240.

107 "the driver must be externally restrained from killing himself." Ibid.: p. 238.

108 Ibid.: p. 32. 
incluindo meios de transporte sobre trilhos ${ }^{109}$. Em sua maioria, os planos de vias expressas tinham como função principal conectar os centros comerciais das cidades com as demais regiões, em especial os crescentes subúrbios residenciais. Financiados por associações comerciais, os planos buscavam reverter a tendência existente nas cidades americanas de descentralização das atividades econômicas, influenciada em grande parte pela expansão do número de automóveis nas cidades americanas ${ }^{110}$.

Apesar de manter parte do repertório formal tradicional de projeto urbano, ainda preocupado com questões espaciais, questões relacionadas à eficiência e fluidez do tráfego eram a grande prioridade. Conceitos relacionados ao planejamento urbano também ganham força nesse período como forma de controlar o desenvolvimento desordenado da cidade, trazendo o debate do urbanismo para aspectos mais técnicos e funcionais do que estéticos ou morais. Planejadores urbanos da década de 1920 nos Estados Unidos - com destaque para a figura do urbanista Harland Bartholomew - pretendiam transformar o planejamento urbano em ciência - através de estudos econômicos, de uso do solo e de pesquisas de transporte - relacionados a princípios de uma estrutura urbana racional ${ }^{111}$. Para DiMento e Ellis, " a ascensão dos planejadores do movimento City Efficient marcou uma mudança dentro do planejamento urbano, do 'projeto cívico' para o 'planejamento funcional', encarando a cidade primordialmente como um local eficiente de produção e de consumo" ${ }^{112}$. De acordo com os principais planejadores urbanos, o processo de descentralização associado ao declínio da cidade tradicional era preocupante. Áreas centrais eram consideradas ativos econômicos de grande importância e a rápida desvalorização poderia levar à decadência da cidade tradicional e um espraiamento excessivo das atividades econômicas em direção aos subúrbios ${ }^{113}$. Ao mesmo tempo, outros profissionais eram otimistas em relação ao crescimento da cidade. Alvan Macauley, presidente da Packard Motor Car Companyafirmava, em 1929, que "novas cidade florescerão ao redor da antiga e essas nova partes rapidamente crescerão em valor, para o lucro dos proprietários dessas terras e enormes perdas ocorrerão àqueles com grandes investimentos nas partes valorizadas das comunidades mais antigas" ${ }^{114}$. Muitos de seus proponentes enxergavam as vias expressas urbanas como catalizadores de um processo de desenvolvimento e revitalização urbana, elementos de progresso social ${ }^{115}$. De acordo com DiMento e Ellis, as transformações prometidas eram vistas com otimismo:

"Profissionais urbanos do final dos anos 1930 e início dos anos 1940 retrataram uma cidade racional e modernizada como a inevitável onda do futuro. A cidade moderna imaginada radiava apenas simbolismo positivo: elevação, claridade, higiene, velocidade, ordem racional e o uso positivo da força estatal. Em contraste, a antiga cidade estava coberta de imagens negativas de desordem e decadência ${ }^{\prime \prime 116}$ Propostas para

\footnotetext{
109 BROWN, 2005: p. 09-10.

110 Ibid.: p. 10.

111 DIMENTO, ELLIS, 2014: p. 25.

112 "The rise of the City Efficient planners marked a shift within the planning movement from 'civic design' to functional planning, viewing the city primarily as an efficient site for production and consumption." DIMENTO, ELLIS, 2014: p. 25.

113 Ibid.: p. 13.

114 "New cities will spring up around the edges of the old and these new sections will rapidly rise in value, to the profit of those who own that realty and to the enormous loss of those with great investments in the now valuable sections of the older communities" Apud. NORTON, 2008: p. 243.

115 DIMENTO, ELLIS, 2014: p. 02.

116 Ibid.: p. 39.
} 
vias expressas desse período eram marcadas pela sua preocupação com o espaço urbano, seja integrando-se com o tecido urbano existente, ou fazendo parte de planos para cidades do futuro. DiMento e Ellis afirmam que "documentos de engenheiros de rodovias falavam não apenas de freeways mas também de cidades modernas, racionalmente desenhadas, dotadas de mobilidade expandida e prosperidade econômica" ${ }^{\prime 117}$. Alguns planos também encaravam as intervenções como oportunidades de substituição de áreas urbanas obsoletas ou degradadas ${ }^{118}$, onde a mistura caótica de diferentes atividades urbanas era considerada desordenada e ineficiente. Em contrapartida, o urbanismo de viés cientifico buscava ordenar a cidade através do zoneamento e da construção de infraestrutura adequada. A substituição de bairros considerados "desordenados" por novas infraestruturas de circulação era considerada absolutamente positiva, sem imaginar que - como afirmam DiMento e Ellis - possíveis conflitos entre infraestrutura e vida urbana ainda pudessem existir mesmo após a segregação das atividades urbanas:

"Planejadores e engenheiros da década de 1930 estavam confiantes de que vias expressas urbanas poderiam abrir um novo mundo de transporte pessoal individual, ao mesmo tempo que melhorariam a qualidade ambiental da cidade. Eles não tinham plena noção que poderiam ocorrer dolorosas decorrências das trocas entre acessibilidade e outras dimensões da vida urbana."

"Como afirmou um membro da comissão de planejamento, 'agora que a ciência mostrou as possibilidades por trás do projeto viário moderno, surge uma nova era. Através das ruas de dois andares, do projeto apropriado de artérias de tráfego, passagens subterrâneas, arcadas, e de outras contribuições ao projeto viário científico, existe agora a garantia de que o acesso pode ser fornecido" ${ }^{119}$.

A tentativa de diminuição do impacto dessas estruturas, quando muito, focava nos aspectos visuais e acústicos, negando por completo os aspectos sociais e econômicos nas comunidades afetadas. Pelo contrário, acreditava-se que a remoção de uma área degradada da cidade eliminaria também a pobreza, como se o espaço fosse responsável pela sua existência ${ }^{120}$ e não o contrário.

\section{A CENTRAL ARTERY DE BOSTON}

O Report on a Thoroughfare Plan for Boston, preparado pelo consultor RobertWhitten, em 1930, é emblemático do pensamento desse período. Ao propor vias expressas em áreas de alta densidade nos bairros centrais, o plano sugere a construção de uma pista elevada cortando o centro histórico da

117 DIMENTO, ELLIS, 2014: p. 09

118 Ibid.: p. 13.

119 "Planners and engineers of the 1930s were confident that urban free ways could open up a new world of efficient personal transportation while simultaneously improving the environmental quality of the city. They had no vivid awareness that there might be painful trade-offs between accessibility and other dimensions of urban life." "As one planning board member expounded: Now that science has shown the possibilities through modern street designing, a new era has dawned. Through the facilities of two-level streets, of properly designed traffic arteries, of underpasses, arcades, and of the other contributions to scientific street design, there now is the assurance that access can be provided". DIMENTO; ELLIS, 2014: p. 42.

120 Ibid.: p. 42. 

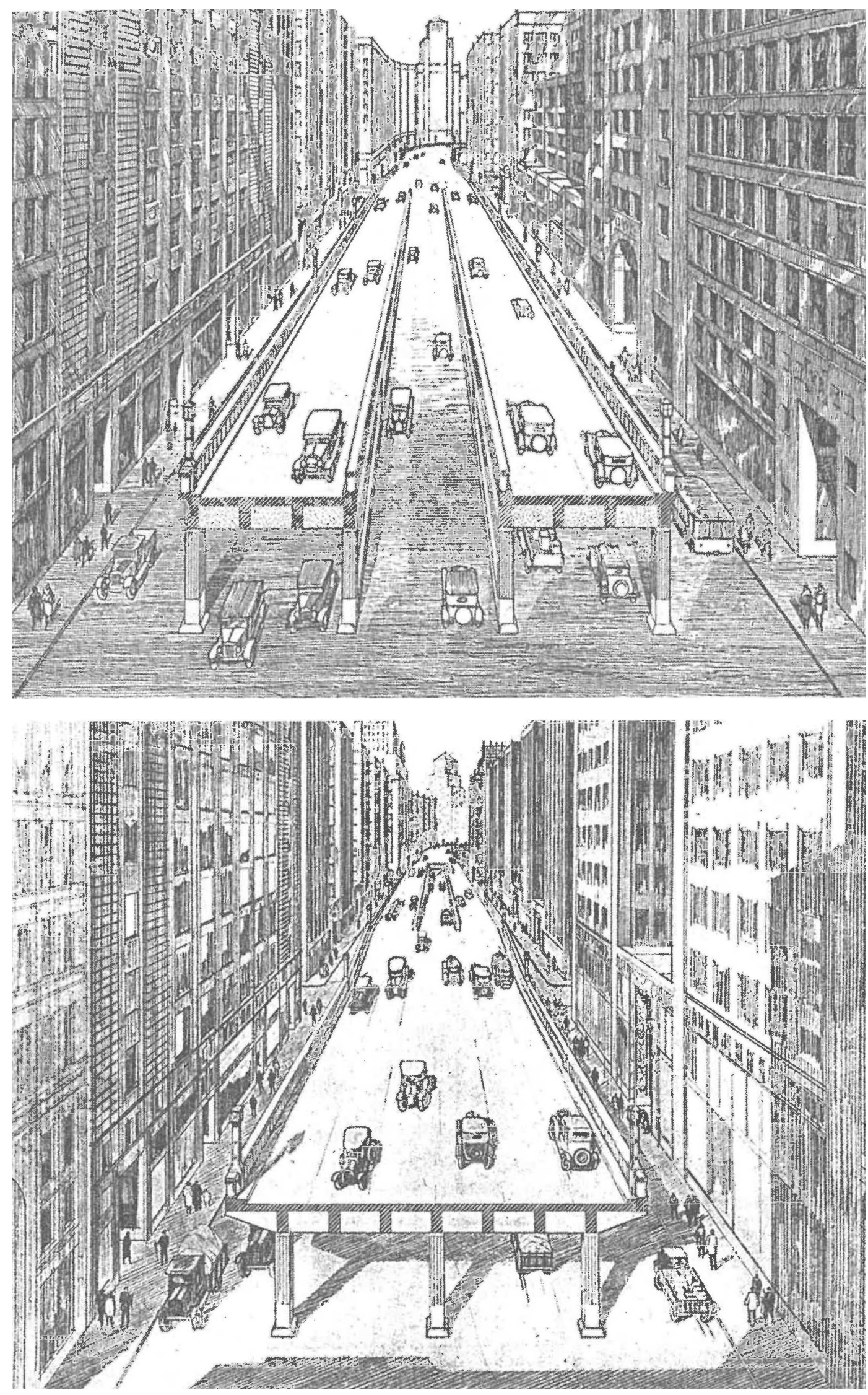

Figura 43 e 44 | Report on a Thoroughfare Plan para Boston, 1930 
cidade. A nova via seria erguida sobre o viário local ${ }^{121}$, passando ao largo do cânion de edifícios construídos junto ao alinhamento da calçada. Sua proposta tenta comparar o movimento de verticalização dos edifícios, transpondo o mesmo raciocínio para o sistema viário. O autor do projeto estava ciente da possibilidade de eventuais problemas, como a perda de iluminação, de visuais, bem como barulhos e uma inevitável vibração da estrutura - afinal, vias elevadas para trilhos já eram uma realidade nas cidades americanas, em Boston inclusive.

Mesmo assim, o argumento que o próprio Whitten considera o mais convincente é a viabilidade de sua execução. Segundo ele, seria a única forma de aumentar a capacidade de tráfego no centro de Boston, já que a solução subterrânea seria tecnicamente difícil e economicamente inviável ${ }^{122}$. A via elevada, no entanto, possibilita o aumento da capacidade viária da cidade sem recorrer a demolições. A colocação das rampas de aproximação no centro da estrutura, por exemplo, evitaria a desapropriação de trechos pontuais, quando normalmente os acessos são projetados nas bordas das rodovias ${ }^{123}$. $\mathrm{O}$ plano também fundia novos conceitos de trânsito em formas mais tradicionais, incorporando ao projeto rotatórias e um grande cruzamento em nível, talvez como forma de integrá-lo ao tecido da cidade de forma mais harmônica.

Apesar de considerar vias elevadas estruturas indesejadas, o autor da proposta acreditava que vias exclusivas para automóveis seriam diferentes, pois seus elementos poderiam ser desenhados de forma mais atraente. Ele acredita que a ocupação restrita à parte central da avenida, aliada a formas atrativas poderiam suavizar seu impacto, afirmando também que automóveis não causariam tantos ruídos quanto trens. $\mathrm{O}$ autor descreve a via elevada:

"A menos que a via expressa completa tenha elementos de charme e beleza, provavelmente será um tanto rudimentar e deficiente do ponto de vista da eficiência do tráfego assim como da prevenção da destruição de áreas adjacentes. Não deve ser apertado, mas deve ter linhas naturais fluidas. Ela deve ser ampla, com espaço para arbustos e árvores além de dispersar as ondas sonoras do tráfego. Deve ter uma aparência agradável, semelhante a um parque, adicionando alguns elementos de interesse e distinção ao bairro pelo qual passa "124.

Em contrapartida, profissionais envolvidos em outros projetos semelhantes já denunciavam esse tipo de estratégia, onde "medidas estéticas" eram aplicadas sobre projetos viários, realizadas por arquitetos e paisagistas como forma de "cosmético," após a concepção inicial de engenheiros rodoviários ${ }^{125}$.

121 Esta via seria posteriormente construída, tendo sido mais recentemente demolida pelo projeto "The Big Dig", que enterrou o sistema de vias expressas de Boston. DIMENTO; ELLIS, 2014: p. 29.

122 Ibid.: p. 31.

123 Ibid.: p. 31.

124 "Unless the completed expressway has elements of charm and beauty, it will probably prove somewhat crude and deficient from the standpoint both of traffic efficiency and of preventing the blighting of adjacent areas. It must not be cramped but must have natural flowing lines. It must be spacious, with room for shrub and tree and for the dispersion of the traffic sound waves. It should have a pleasant, park-like appearance that will add some elements of interest and distinction to the neighborhood through which it passes" Apud. DIMENTO; ELLIS, 2014: p. 42.

125 "In a 1930 article in American City, Richard Schermerhorn, Jr., a planner and landscapearchitect in New York City, worried that aesthetic measures werebeing applied to highways as cosmetics, after all of the major decisionshad already been made by engineers. This was like 'starting the job in the middle' and relegated the role of the landscape architect to the 'incidental planting of shrubs and vines.' Schermerhorn argued that 'Highway structures such as bridges, culverts, underpasses, etc, should be designed by architects or landscape architects instead of engineers'." DIMENTO; ELLIS, 2014: p. 33. 

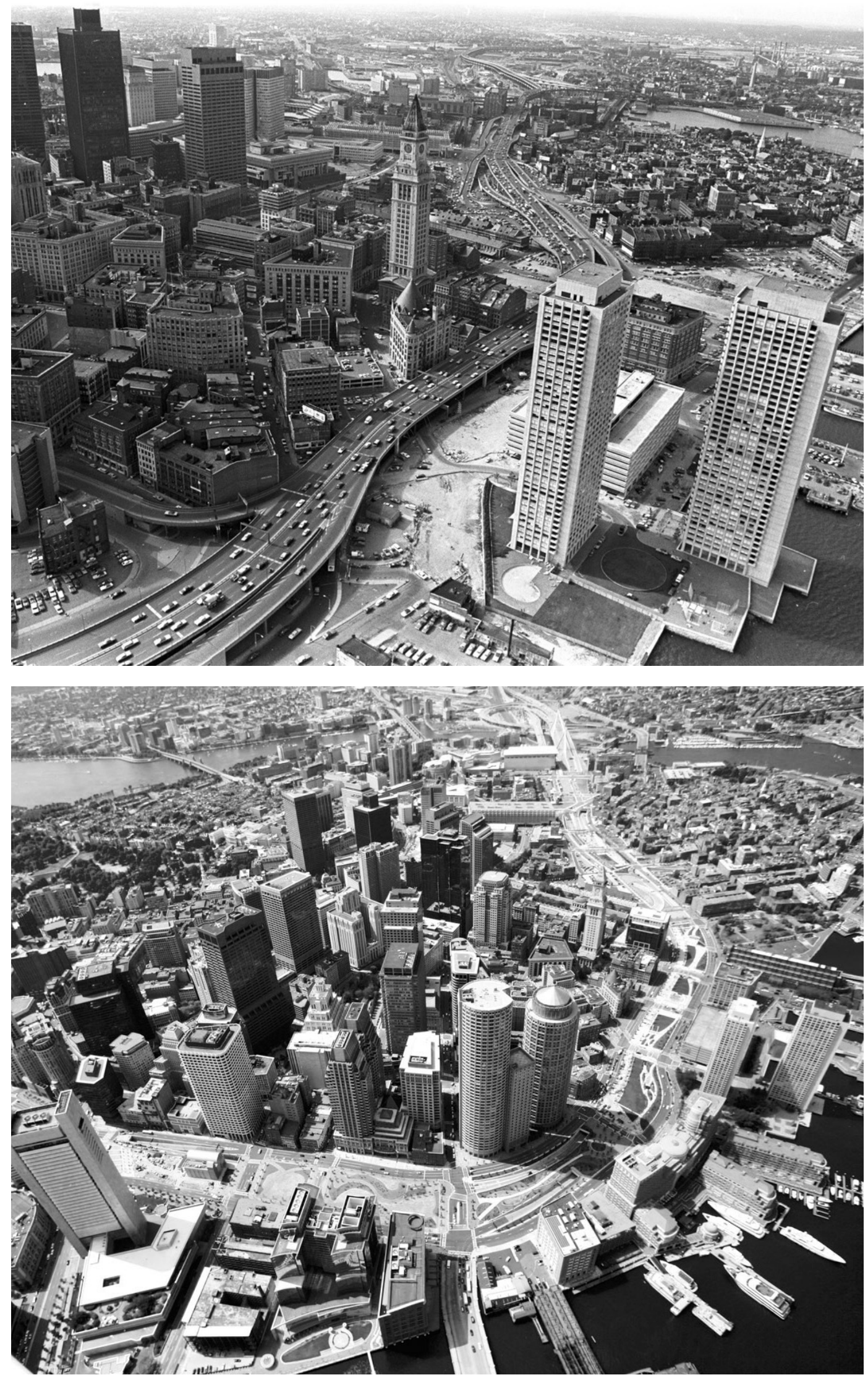

Figura 46 | Boston - Central Artery, 1972

Figura 47 | Boston - The Big Dig, 2007 
O projeto de uma via expressa elevada no cento de Boston continuou na agenda da cidade, sendo posteriormente construída nos anos 1950. A Boston Central Artery fazia parte de uma rodovia interestadual, cruzando o centro da cidade na direção norte-sul, separando também o centro de negócios da cidade de sua frente d'agua portuária. Responsável pela deterioração da parte central da cidade, a via elevada foi substituída por uma complexa operação urbana conhecida como "the Big Dig". Nesse controverso projeto, as pistas antes elevadas foram substituídas por um conjunto de túneis por onde passa o tráfego interestadual.

\section{AS VIAS ELEVADAS DE NOVA IORQUE}

Enquanto Boston ainda mantinha suas vias expressas elevadas apenas nos planos, Nova lorque já construía suas primeiras vias elevadas. A West Side Elevated Highwayfoi construída em 1927 em Manhattan, às margens do Hudson, na porção sul da cidade. A via expressa urbana elevada era um verdadeiro ovo de colombo, resolvendo o problema do deslocamento nas cidades construindo-se sobre o caos urbano. A execução de vias elevadas como esta estimularia posteriormente a construção de estruturas semelhantes em Nova lorque e no restante do país ${ }^{126}$. Para Frederick Etchelles, crítico de jornal da época, a West Side Highway era uma solução bem-vinda para o congestionamento das cidades, onde "a velocidade dos carros será de trinta milhas por hora ou mais. Todos os cruzamentos foram eliminados" ${ }^{\prime 27}$. Le Corbusier também saudava as vias elevadas de Nova lorque:

"Como a avenida marginal estava congestionada, decidiram construir (...) o instrumento salvador de todo urbanismo moderno: a auto-estrada sobre pilotis (...). Neste inferno da circulação, lançamo-nos com força total, evadimo-nos, em uma alegria verdadeira, sobre a auto-estrada elevada: vemos os navios, águas a perder de vista, os arranha-céus, o céu; somos livres! "128

De tipologia semelhante, a Gowanous Parkway fora concebida por Robert Moses entre 1939 e 1941 sobre a estrutura de uma antiga linha férrea pré-existente. Mesmo aproveitando-se da estrutura já construída, as rampas de acesso da via expressa requisitavam a demolição de parte das construções adjacentes, ocupados por comerciantes e moradores. Balanços sobre a estrutura existente seriam adicionados, de modo a ampliar a quantidade de faixas da rodovia. Parecia uma solução inteligente a elevação das pistas da via expressa, como escreveu o editorial daTimes: "quando o comissário Moses encontra a superfície demasiadamente congestionada para uma de suas parkways, ele eleva a via aos ares e continua o seu percurso" ${ }^{\prime 29}$.

Vias expressas elevadas eram descritas como bons vizinhos, às vezes até como elementos arquitetônicos de destaque. As ilustrações dos projetos mostravam na maioria das vezes as vias em sua porção superior, sem ilustrar a tenebrosa situação ao nível do solo. Na imagem abaixo, do plano Selected Measures for the Partial Relief of Traffic Congestion in New York City, de 1946, uma via expressa cruza Manhattan quase desapercebidamente, no último plano, como se não fosse causar impacto negativo algum em seu espaço urbano circundante ${ }^{130}$.

129 "when Commissioner Moses finds the surface of the eart too congested for one of his parkways, he lifts the road into the air and continues in on its way."Apud. CARO, 1975: p. 520

130 DIMENTO; ELLIS, 2014: p. 99-101 


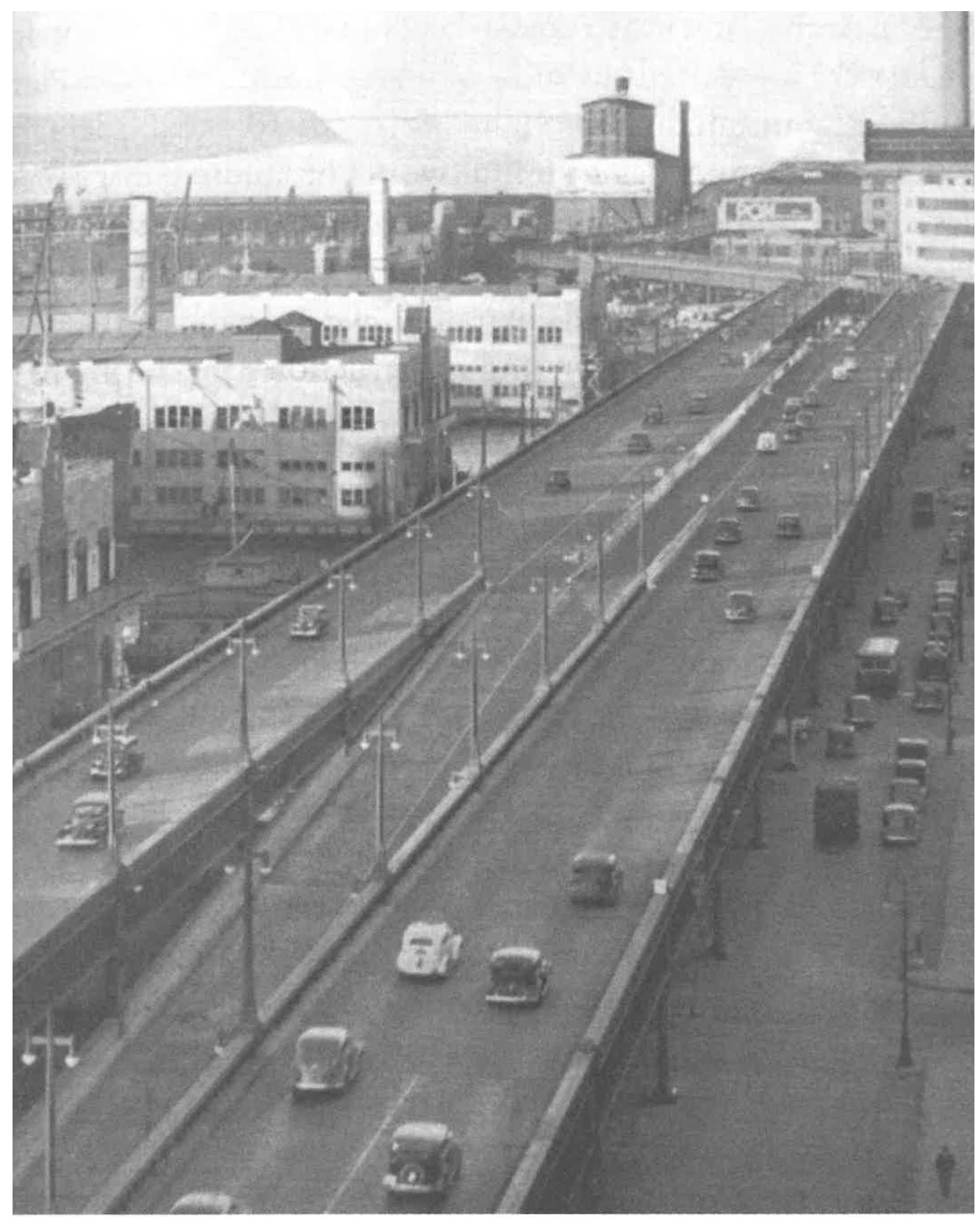

Figura 46 | West Side Elevated Highway, 1944

A escolha do local de implantação da rodovia foi polêmica por conta de seu impacto nos arredores. O bairro de Sunset Park, que recebeu a estrutura, possuía áreas de características diferentes: enquanto a região próxima a estrutura ferroviária abandonada desfrutava de uma vida urbana consolidada, a faixa junto à margem do East River era ocupada apenas por piers, fábricas e áreas abandonadas. Contrariamente aos interesses de Moses, que pretendia baratear a construção do elevado lançando mão da estrutura pré-existente, a população local defendia a mudança do traçado para que fosse deslocado para a avenida junto ao rio. Ao ser questionado sobre as possibilidades de um impacto negativo da estrutura em Sunset Park, Moses afirmou que o bairro não merecia ser preservado por se tratar 
de uma favela ${ }^{131}$, sendo assim passível de sofrer uma intervenção. Contudo, apesar de se tratar de um bairro pobre, existia ali uma população de setenta mil habitantes vivendo em uma estrutura social consolidada, tornando as ruas do bairro vivas, repletas de atividades. Em contrapartida, para os planejadores de rodovia, a via expressa passaria sobre o caos da cidade tradicional, isolando-a dos problemas urbanos que prejudicam a eficiência das estruturas de deslocamento.

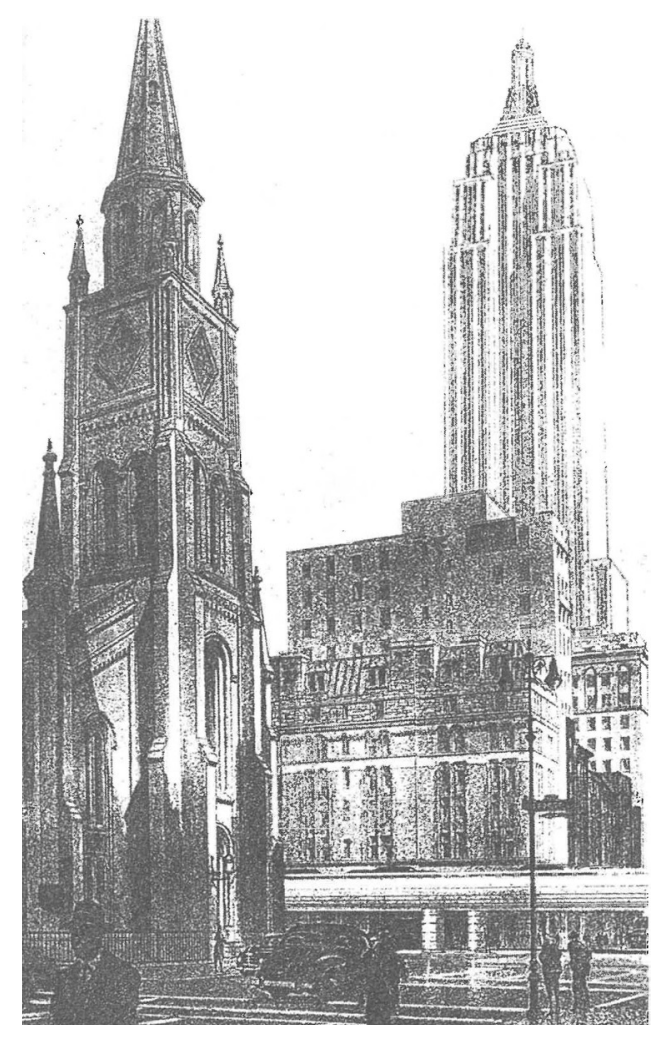

Figura 47 | proposta para freeway elevada através de Manhattan, 1946

A construção da Gowanous Parkway lançou Sunset Park às sombras. Ao contrário das vazadas estruturas da ferrovia, as lajes da rodovia eram sólidas e sua largura era duas vezes maior que a estrutura original. Como resultado, houve abandono significativo das atividades comerciais após sua inauguração. Diferentemente da ferrovia, que trazia pessoas das estações para uma avenida junto ao chão, repleta de vida urbana, a rodovia estava completamente isolada do bairro. A área sob a estrutura, sem qualquer tipo de iluminação - seja diurna ou noturna - se tornou um depósito de lixo, úmido, uma tremenda barreira psicológica ${ }^{132}$. Como resultado, a população de Sunset Park abandonou a avenida sob a parkway, e ao longo dos anos a decadência da avenida se espalhou em direção às ruas transversais. 




\title{
III/ 4.
}

\section{A RODOVIA \\ VENCENDO A CIDADE}

\author{
"Todos nos Estados Unidos estão esperando \\ pelo fim da guerra para entrar em \\ um carro para ir a algum lugar"
}

Thomas MacDonald

"O desenvolvimento da modernidade transformou a própria cidade moderna num elemento antiquado e obsoleto. Realmente, as pessoas, as visões e as instituições da cidade criaram a via expressa - A Nova lorque deve ser creditada a invenção das parkways. Agora, entretanto, por obra de uma dialética fatídica, como a cidade e a rodovia não se coadunam, a cidade deve sair"

Marshall Berman 



\subsection{VIA EXPRESSA COMO PROJETO NACIONAL NORTE-AMERICANO}

Durante a Segunda Guerra, entre 1939 e 1945, o ritmo de construção de novas rodovias nos Estados Unidos foi interrompido, atendendo apenas demandas estratégicas de cunho militar. O debate acerca da construção de um sistema nacional de rodovias já apontava para um consenso entre diversos especialistas desde a década de 1930, mas sua construção permanecia inviável enquanto houvesse recessão econômica. No entanto, foi durante esse período de pouca construção que os projetos de vias expressas atingiram um novo patamar, rumo ao estabelecimento de padrões de projeto e construção de rodovias que seriam largamente difundidos pelo país - e posteriormente pelo mundo.

No período de construção de parkways, entre os anos 1920 e 1930, foram projetadas e construídas estradas de acesso limitado com grande qualidade de desenho, gerando belíssimos resultados. No entanto, esse modelo acabou não sendo replicado no período posterior à Segunda Guerra, quando engenheiros rodoviários estaduais dominaram a agenda de construção de vias expressas. Foram deixados para trás os modelos de projeto mais modestos e mais sensíveis ao contexto, realizados por urbanistas locais, para serem substituídos por grandes projetos viários, dimensionadas para pesados movimentos de veículos. A entrada de um contingente cada vez maior de veículos nos centros urbanos assumiu prioridade máxima. O ideal da parkway se tornou obsoleto, dando espaço a projetos geométricos dedicados a questões de fluidez, garantindo, com largas pistas e grandes raios de curvatura, altas velocidade em segurança para um alto volume de tráfego ${ }^{1}$, passando sobre o que fosse necessário para atingir seus objetivos.

Após o fim da Segunda Guerra Mundial, a questão urbana nos Estados Unidos entra em um novo patamar e o problema do trânsito estava maior do que nunca. No entanto, não seria necessário optar entre o bucolismo da rodovia pastoral e o "progressismo" das vias expressas em áreas centrais. Pelo contrário, a cidade futura norte-americana direcionaria esforços em ambas as direções: ao mesmo tempo que ambiciosos projetos viários despontavam sobre os tradicionais centros consolidados, o governo também continuaria a direcionar esforços para o crescimento dos subúrbios, através de um agressivo programa de construção de autoestradas e da priorização de financiamentos habitacionais para unidades unifamiliares afastadas do centro. A rodovia pastoral antiurbana como tipologia entraria de uma vez por todas no domínio da cidade tradicional e ao mesmo tempo o espaço do rural seria contaminado pelas formas de urbanismo suburbanas. A distinção entre cidade e campo passaria a se tornar cada vez mais difícil de ser reconhecida: os centros urbanos das novas cidades perderiam a densidade habitacional da cidade tradicional dos cem anos precedentes, enquanto que o campo passaria a se tornar também local de moradia de cidadãos urbanos. 
Transformações sociais e culturais também teriam grande importância no espaço urbano. Música, cinema, design, propaganda, consumo, tudo se uniria em uma única entidade ditadora de padrões de comportamento social, chamada por Horkheimer e Adorno, filósofos da Escola de Frankfurt, de "Indústria Cultural" ${ }^{2}$. Para Fredrich Jameson, tratava-se do surgimento de um novo tipo de sociedade:

"Novos tipos de consumo, a obsolescência planejada, um ritmo mais alto de mudanças da moda e no estilo, a penetração da propaganda, um nível de inserção na sociedade, até então sem paralelo, da televisão e da mídia em geral, a substituição da velha tensão entre a cidade e o campo, o centro e a província, pela tensão entre o subúrbio e a padronização universal, o crescimento das grandes redes de estradas de alta velocidade e a chegada da cultura do automóvel - esses são alguns dos aspectos que poderiam parecer marcar uma ruptura radical com aquela sociedade pré-guerra ${ }^{\prime 3}$.

Dentre essa produção normativa destacam-se dois documentos elaborados dentro do poder público federal norte-americano - Toll Roads and Free Roads (1939) e Interregional Highways (1944) - que foram particularmente fundamentais para o estabelecimento de diretrizes de projeto de vias expressas e sua relação com o espaço urbano ${ }^{4}$. Os trabalhos indicavam a maneira como rodovias da esfera federal deveriam se relacionar com as cidades, seja através de anéis perimetrais, ou mesmo penetrando e atravessando seu centro. É nesse período onde os planos de vias expressas urbanas concebidos ao longo das décadas de 1920 e 1930, de Parkways e Expressways, de escala mais modesta são substituídos por ambiciosos projetos de vias rápidas urbanas de alta capacidade. Concebidas por engenheiros de rodovias, essas novas estruturas tinham como principal finalidade tornar a cidade mais eficiente, permitindo a maior fluidez de veículos possível e um deslocamento urbano mais veloz, sobretudo dos fluxos entre os centros urbanos e os subúrbios residenciais em ascensão. Como resultado, a preocupação com a inserção desses artefatos no planejamento urbano e na paisagem desaparecera; o desenvolvimento das políticas de trânsito estava sendo deslocado da pauta metropolitana em direção a uma pauta de planejamento regional e federal ${ }^{5}$.

\section{O RELATÓRIO TOLL ROADS AND FREE ROADS, 1939}

Em 1937, a pedido do presidente Franklin D. Roosevelt, após tomar conhecimento das Reichsautobahnen da Alemanha nazista, o Bureau of Public Roads - entidade de pesquisa em engenharia de rodovias mais prestigiosa do país no período - iniciou estudos de viabilidade para a construção de vias pedagiadas transcontinentais no território norte-americano, três rodovias paralelas ligariam as costas leste e oeste, enquanto que outras três cruzariam o país de norte a sul. O relatório resultante dessa pesquisa, Toll Roads and Free Roads (1939), se tornou posteriormente um documento fundamental para a política nacional de transportes ${ }^{6}$.

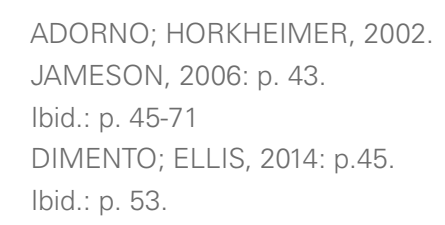


O relatório discordava da premissa estabelecida pela encomenda inicial onde o sistema federal de rodovias deveria simplesmente conectar cidades distantes, propondo a complementação das vias com pedágios com um sistema de quase quarenta e três mil quilômetros de vias "livres", que pudessem, em alguns trechos, penetrar na cidade. Segundo DiMento e Ellis, naquele período o Bureau of Public Roads argumentava assertivamente em favor de segmentos urbanos ao longo do sistema inter-regional como forma de resolver o problema dos congestionamentos urbanos. A seção do relatório intitulada "A Master Plan for Freeway Development" foca especificamente nas condições das cidades existentes, sendo a primeira análise aprofundada acerca do tema desenvolvida em âmbito federal ${ }^{7}$, antes discutida apenas em nível municipal.

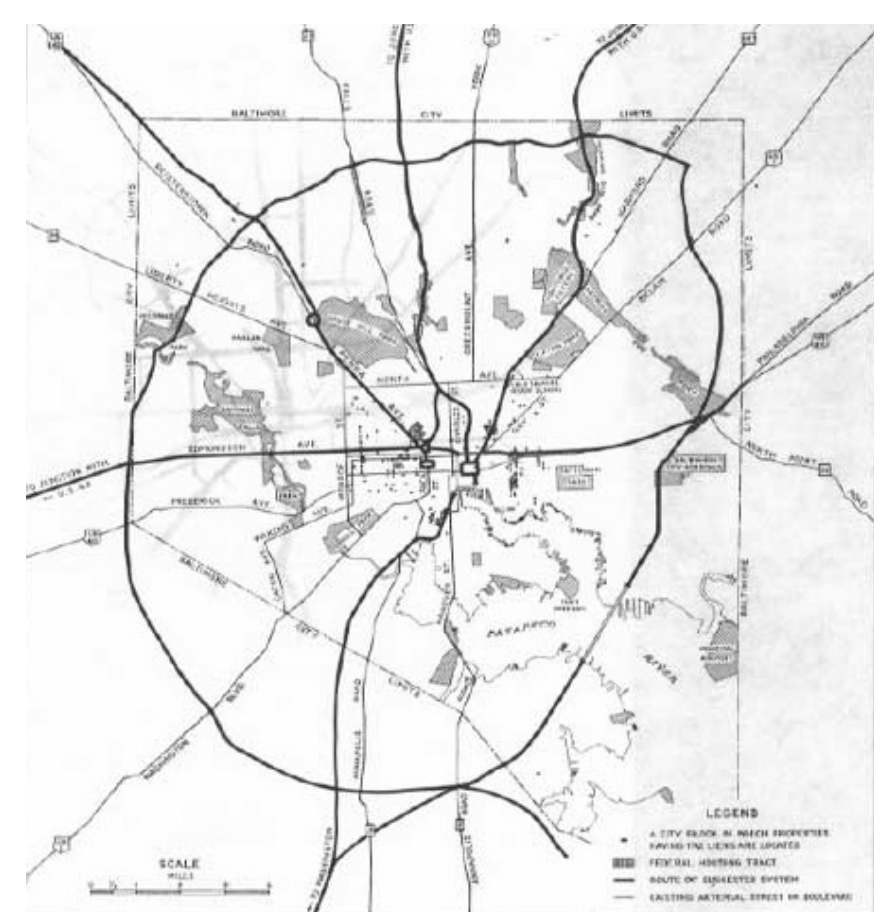

Figura 48 | Toll Roads and Free Roads, 1939 - Estudos de traçado viário para a cidade de Baltimore

O relatório defende a tese de que vias expressas radiais de alta capacidade, que levassem veículos aos centros urbanos, eram essenciais, provendo infraestrutura viária para a principal demanda das cidades ${ }^{8}$. Dominado por critérios de engenharia e economia, o relatório destaca as dificuldades comuns à construção de vias expressas em áreas consolidadas: o custo de desapropriação de terrenos nas áreas centrais, bem como as dificuldades de estabelecimento do traçado viário - seja ele elevado ou em trincheira - em áreas densamente ocupadas, com interferências em outras redes de infraestrutura ${ }^{9}$. Mesmo assim, o relatório aponta a necessidade de transformação do espaço urbano para se adequar ao automóvel como algo inevitável ${ }^{10}$, desprezando a importância do transporte coletivo como ferramenta de mobilidade urbana.

7 DIMENTO; ELLIS, 2014: p. 54.

8 De acordo com o próprio relatório, "the only course that promisses a really satisfactory solution is the provision of adequate facilities for conduct or the heavier entering traffic streams through the city at or near its center, and on to appropriate exit points."Apud. DIMENTO; ELLIS, 2014: p. 55.

9 DIMENTO; ELLIS, 2014: p. 56.

10 Ibid.: p. 57. 
O relatório estabelece o que seria um "padrão para novas vias expressas urbanas" ${ }^{11}$ denominado "hub-and-wheel pattern", que transfere para a lógica da rodovia os conceitos de um esquema urbano radial-perimetral, mesclando a estrutura rodoviária com o tecido urbano das cidades. Para que funcionassem de forma eficiente, as vias radias deveriam penetrar nos centros comerciais por todas as direções possíveis, enquanto que as conexões entre as rodovias seriam realizadas por um anel ${ }^{12}$. Para cidades maiores seria necessária a construção de dois anéis, o primeiro rodeando o centro comercial da cidade, enquanto que o segundo contornaria sua periferia ${ }^{13}$.

A determinação do traçado viário ao longo de bairros degradados ao redor do centro das cidades era uma das soluções apontadas para diminuir o custo de implementação dos anéis de conexão dos eixos radiais ${ }^{14}$, conforme descreve o próprio relatório:

"Em alguns casos, pode ser possível construir o anel de distribuição dentro da cidade - geralmente em algum lugar dentro do anel de propriedade decadente que rodeia a área de comércio central. Essa perimetral conectada em pontos apropriados com artérias radiais que se estendem para fora da cidade, pode evitar o corte de uma nova rota diretamente através das seções de comércio e pode servir como um substituto ou suplemento para a perimetral externa"15

Junto com o movimento de fuga da classe média urbana norte-americana em direção aos subúrbios, os antigos bairros residenciais, que circundavam os centros urbanos, passavam gradualmente a abrigar atividades comerciais, enquanto que antigas casas unifamiliares eram transformadas por seus proprietários em cortiços destinados a famílias de baixa renda. De acordo com o relatório, esses bairros considerados "degradados" seriam beneficiados pela construção de novas vias de circulação. Assim, seriam demolidas diversas das antigas edificações do bairro, em nome do progresso e pelo bem da sua "revitalização." A estratégia se baseava no argumento de que através da remoção de edifícios degradados, também seriam resolvidos os problemas sociais de uma região. Desse modo, afirma o relatório, as novas vias expressas urbanas seriam capazes de melhorar as condições de mobilidade, adequando seu traçado viário que "embaraça o movimento do trânsito do século XX"16, e "curar" a desordem social e decadência espacial da cidade tradicional ${ }^{17}$. Apesar de sua linguagem técnica, o relatório incorpora o discurso a favor do processo de modernização, onde melhoramentos no tráfego teriam um poder quase mágico no desenvolvimento do ambiente urbano. O relatório destaca as obras de Robert Moses em Nova lorque, citadas com entusiasmo como um bom exemplo de conduta ${ }^{18}$. Por conta de sua abrangência e importância com que foi recebido pelos especialistas, o relatório foi responsável pela posterior disseminação desses conceitos.

11 "A pattern for new urban freeways."DIMENTO; ELLIS, 2014: p. 58.

12 O termo utilizado no relatório, em inglês, é "beltway", ou "belt line".

13 DIMENTO; ELLIS, 2014: p. 58.

14 Ibid.: p. 56-7.

15 "In some cases, it may be feasible to construct the distributing belt line within the city - generally somewhere within the ring of decadent property surrounding the central business area. Such a belt line, connecting at appropriate points with radial arteries extending out of the city, may avoid the cutting of a new route directly through the business sections, and may either serve as a substitute or supplement for the outer belt line" Apud. DIMENTO; ELLIS, 2014: p. 58.

16 "countless impediments that embarass the movement of the twentieth-century traffic."Trecho extraído do relatório, citado por DIMENTO e ELLIS (2014: p. 58).

17 Ibid.: p. 57.

18 Ibid.: p. 58. 
Em momento posterior, o chefe do Bureau of Public Roads, Thomas H. MacDonald, argumenta a favor das vias expressas urbanas como forma de qualificação do espaço urbano em um artigo, de 1947, intitulado "The Case for Urban Expressways". Nele, o autor defende o princípio onde vias expressas deveriam ser construídas em parceria com novas moradias, como forma de renovar o espaço urbano de bairros considerados degradados. Para ele, vias expressas deveriam passar por bairros onde o valor da terra era baixo e "a maioria dos edifícios são do tipo que deveria ser derrubado de qualquer maneira, para livrar a cidade de seus bairros pobres" ${ }^{19}$, ou como o mesmo colocou em uma conferência: "É uma circunstância feliz que as condições de vida de uma família possam ser restabelecidas e permitir que a decadência social e econômica no coração das cidades seja convertida em um ativo urbano" ${ }^{20}$. Ademais, MacDonald defende as vias expressas como "a única solução para o problema do trânsito" ${ }^{21}$ nas cidades, sendo muito superiores ao alargamento de vias existentes, que tinham possibilidades limitadas de aumento da capacidade de tráfego: "a questão para nossas grandes cidades não é como bancar vias expressas, mas sim como bancar ficar sem elas" ${ }^{22}$. As cidades não teriam escolha se não aceitar a necessidade de construção de rodovias em seu interior.

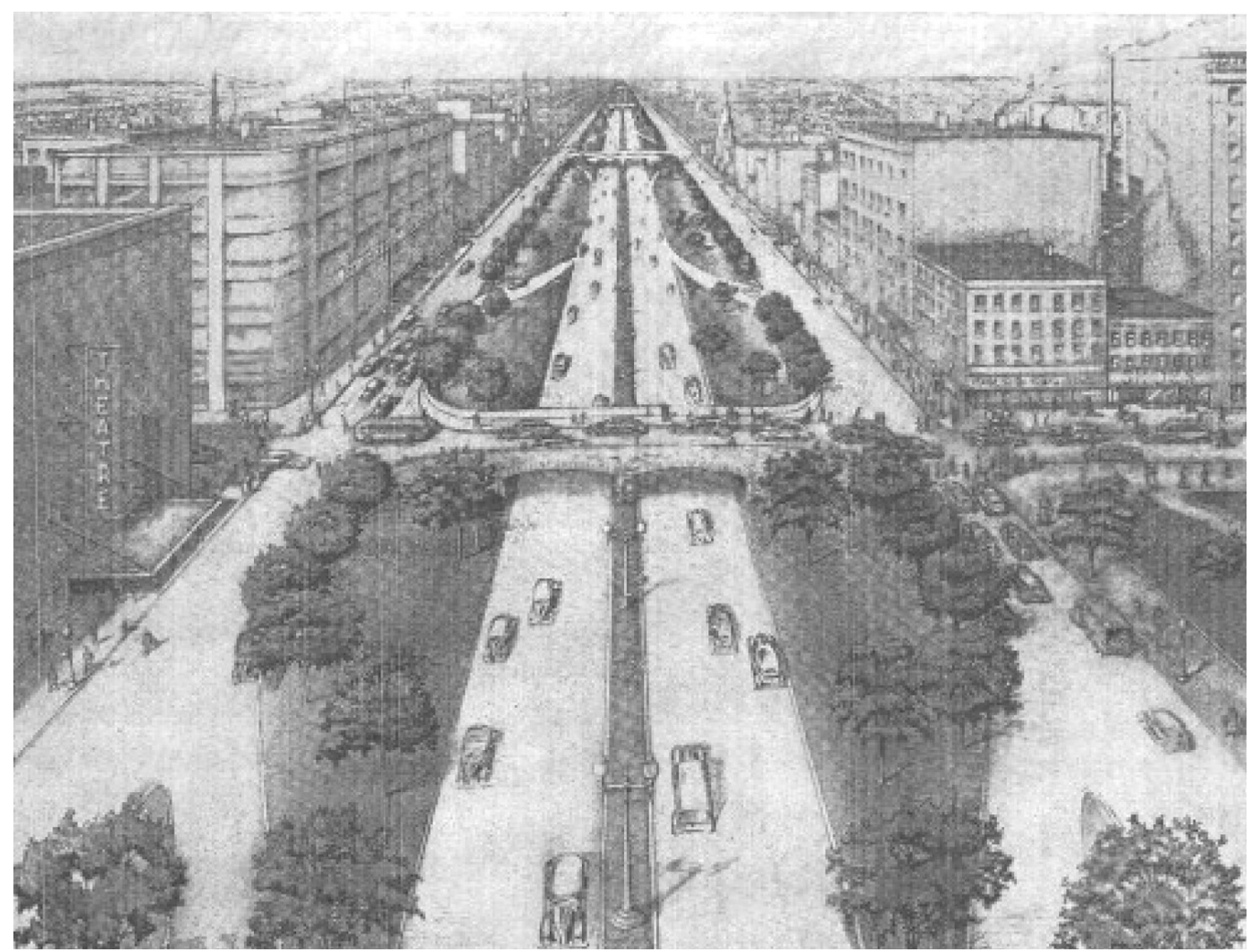

Figura 49 | Toll Roads and Free Roads - Via Expressa Urbana

19 "most of the buildings are of the type that should be torn down in any case, ti rid the city of its slums ."Apud. DIMENTO; ELLIS, 2014: p. 76.

20 Apud. ROSE, 1990: p. 99.

21 "It is a happy circumstance that living conditions for the family can be re-established and permit the social as well as economic decay at the heart of the cities to be converted to a public asset.." DIMENTO e ELLIS, 2014 : p. 75 .

22 "the question for our large cities is not can they afford express highways, but how can they possibly afford to be without them."Apud. DIMENTO; ELLIS, 2014: p. 76. 


\section{O RELATÓRIO INTERREGIONAL HIGHWAYS, 1944}

Desenvolvido entre 1941 e 1944, o relatório dá continuidade às análises realizadas em Toll Roados and Free Roads e codifica diversas doutrinas básicas de planejamento de vias expressas urbanas no pós-guerra ${ }^{23}$. O relatório foi responsabilidade do National Interregional Highway Comittee (NIHC), liderado por Thomas MacDonald e contou com a participação não apenas de engenheiros de rodovias, mas também de economistas e profissionais de planejamento urbano e regional, como Harland Bartholomew. O objetivo do relatório era estudar alternativas de redes rodovias inter-regionais que fossem estratégicas do ponto de vista econômico e de defesa. Dos cinco esquemas estudados, o comitê escolheu uma rede de rodovias de quase cinquenta e cinco mil quilômetros, dentre os quais sete mil quilômetros seriam construídos dentro de perímetros urbanos. Ademais, o plano também previa mais oito mil quilômetros de anéis perimetrais e conexões a serem construídos nas grandes cidades ${ }^{24}$.

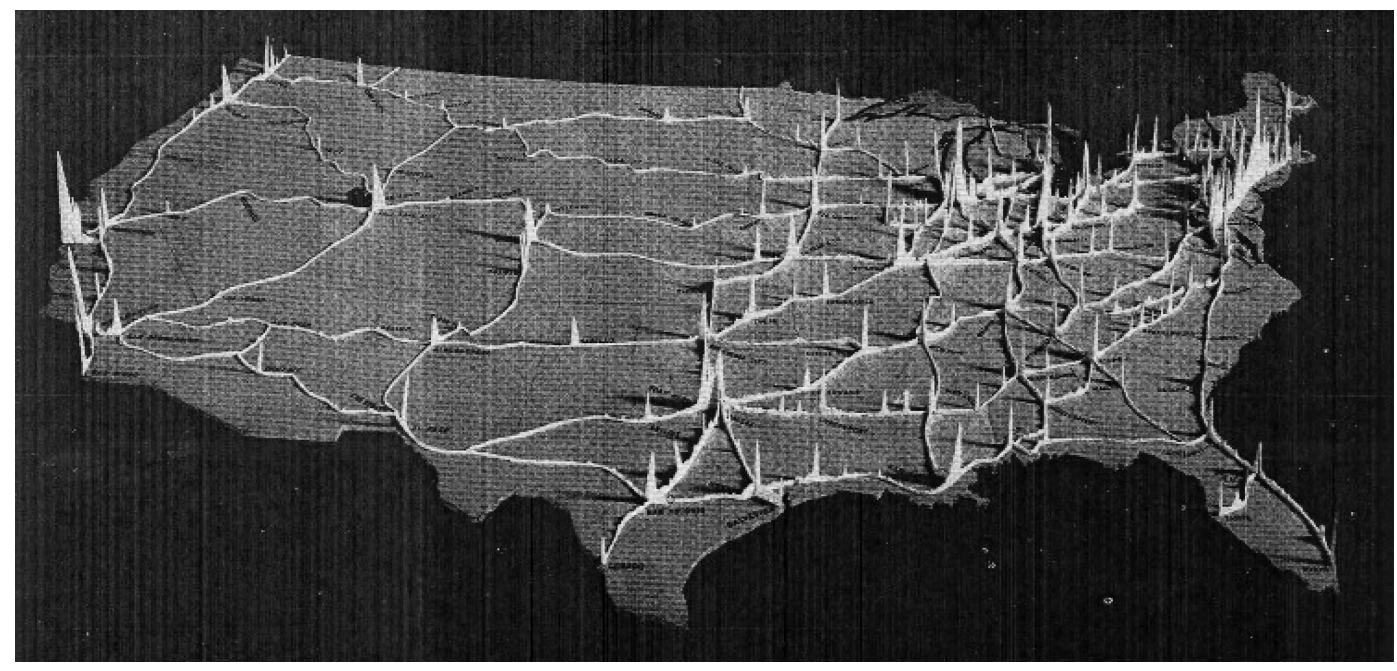

Figura 50 | Interregional Highways, 1944 - Mapa do sistema de vias expressas com gráfico de demanda.

Vale notar a alta demanda em curtas distâncias, representando o tráfego urbano

Dada a larga quantidade de vias em áreas urbanas, o relatório dedicou um capítulo inteiro à relação entre vias expressas e forma urbana, intitulado "Locating the Interregional Routes in Urban Areas."O relatório defendeu o mesmo conceito de hub-and-wheel pattern, presente em Toll Roads and Free Roads, destacando a necessidade de eixos conectando subúrbios e centros urbanos, interligados por anéis ao redor dos centros comerciais ${ }^{25}$. Já nesse período, era possível notar a descentralização de outras atividades urbanas, com a migração de atividades comerciais, industriais e de escritórios para áreas de subúrbio, o que foi pontuado no relatório. No entanto, ele não determina soluções para esse tipo de situação. O relatório apontava a descentralização como um fenômeno desejado, mas que poderia ser prejudicial em casos extremos, onde a expansão não ocorria de forma planejada. Estava claro para seus autores que as futuras vias expressas ali concebidas teriam papel importante na continuidade

24 Ibid.: p.61. Atualmente, o Interstate Highway System - sistema de autoestradas norte-americanas possui $77.000 \mathrm{~km}$ de vias expressas conectando todo o país.

25 Ibid.: p.61. 
desse processo. Por isso, o comitê enfatizou em seu relatório a necessidade de autoridades metropolitanas que contassem com a cooperação de agentes locais e estaduais para determinar o traçado de rodovias em metrópoles compostas por diversos municípios ${ }^{26}$.

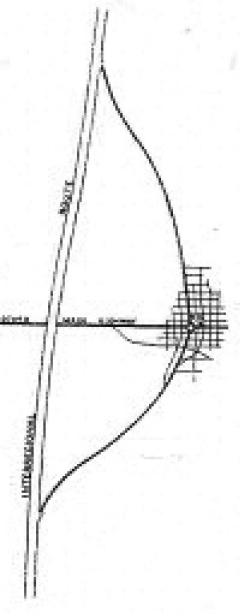

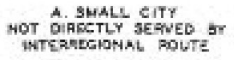
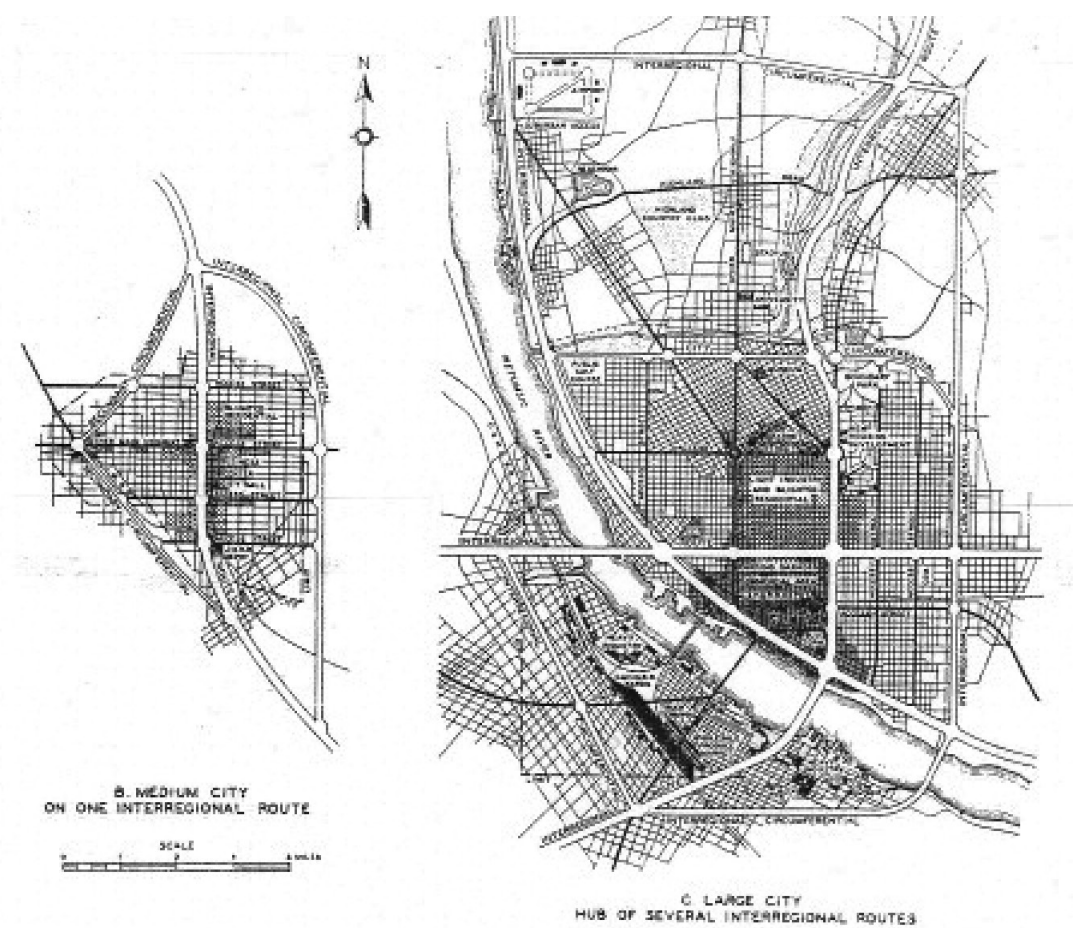

Figura 51 | Interregional Highways, 1944 - Entrada das vias inter-regionais em cidades de tamanhos diferentes.

Preocupado com a inserção urbana das rodovias no tecido urbano das cidades existentes, o relatório dedica uma seção inteira ao estabelecimento de "princípios de seleção de rotas em cidades", designando soluções para a penetração de uma rodovia no tecido urbano. O comitê partiu da premissa de que novas vias expressas deveriam atravessar o tecido urbano com certa proximidade do centro comercial - aproximando-se inclusive de outros modais de transporte sem, no entanto, tocá-lo. De acordo com o relatório, a definição da situação mais adequada para o traçado dessa rodovia dependia das características específicas, estabelecidas caso a caso. Porém, o comitê apresenta algumas soluções genéricas, comuns em diversas cidades, que se transformaram numa espécie de guia para a implantação de rodovias urbanas ${ }^{27}$. Soluções como essas foram largamente utilizadas em projetos de rodovias em diversas cidades, inclusive no Brasil.

O relatório enxerga em diversas cidades a tendência da sua mancha urbana se desenvolver em formato de "estrela", onde seu crescimento acompanha os principais eixos de acesso da cidade. Entre esses eixos de urbanização costumam restar trechos não urbanizados, que poderiam ser utilizados para a construção de vias expressas radiais que penetrassem seu centro. Com o desenvolvimento dessas áreas estimulado pelas novas vias, elas se transformariam em novos vetores de urbanização em uma área mais próxima aos centros urbanos, evitando o que os autores do relatório consideravam uma descentralização excessiva ${ }^{28}$. 
Quanto aos anéis perimetrais, a orientação era semelhante ao apontado por Toll Roads and Free Roads, ressaltando sua importância, tanto da construção de anéis periféricos quanto do anel interior ${ }^{29}$. Este, por sua vez, faria a transição entre as vias radiais e o arruamento do tecido urbano tradicional, distribuiria os carros de maneira homogênea ao longo do contorno do centro da cidade. Dessa forma, seria evitado o tráfego de passagem pelo centro, aliviando o trânsito nessa região. Outra função do anel interior, segundo o comitê, seria a separação clara que essa via criaria entre o centro comercial e os bairros degradados ao seu redor ${ }^{30}$.

O relatório também recomenda a integração das vias expressas com outros meios de transportes - como terminais ferroviários, portos e aeroportos -, assim como polos geradores de tráfego, como arenas esportivas, grandes mercados e áreas industriais.

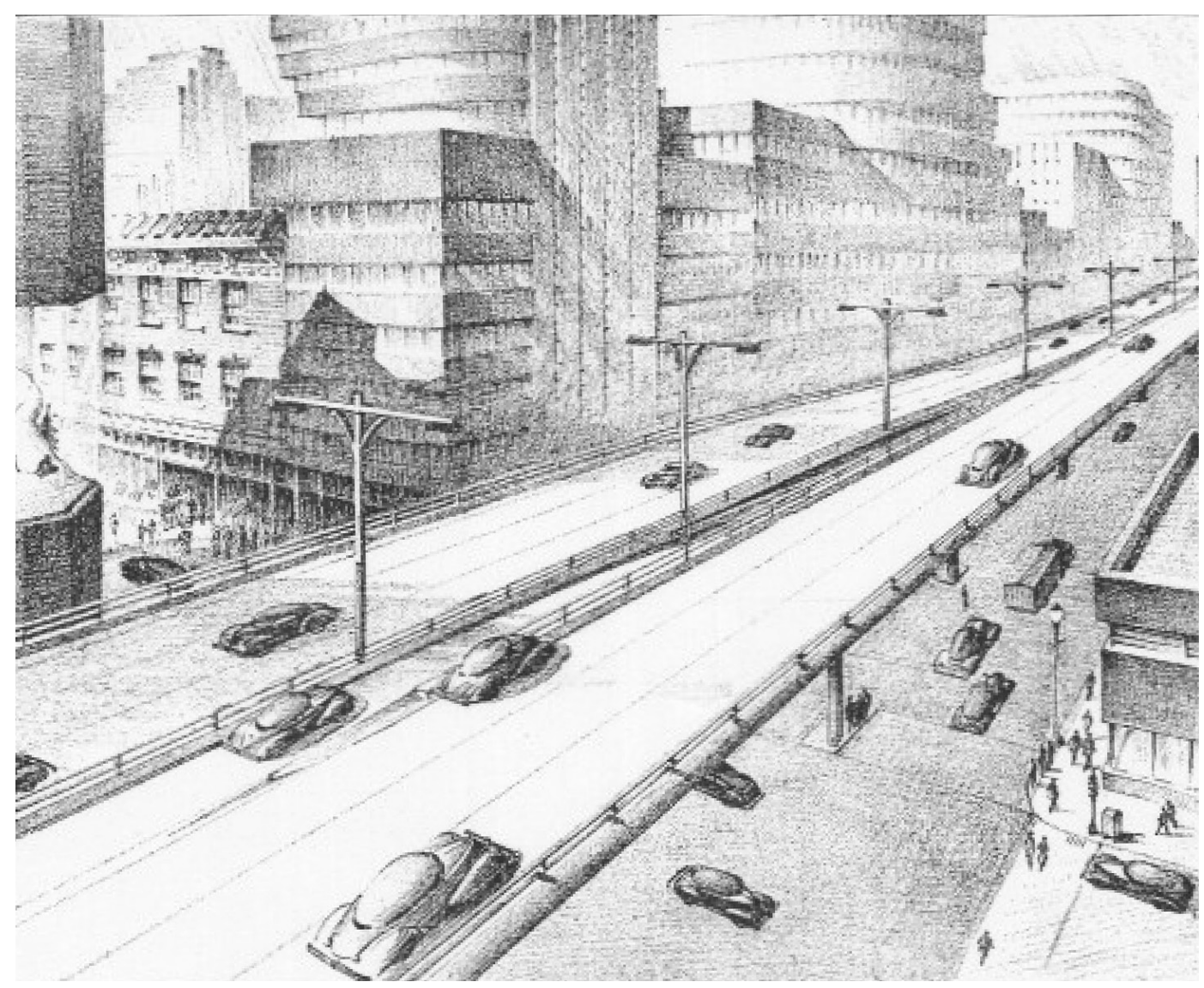

Figura 52 | Interregional Highways, 1944 - proposta de via elevada ${ }^{31}$.

Diversas soluções são recomendadas pelo relatório para que o traçado de vias expressas evitasse ao máximo cruzamentos com o tecido urbano existente, para que ruas não fossem bloqueadas ou que houvesse necessidade de construção em excesso de cruzamentos em desnível. Algumas destas soluções estão descritas abaixo.

31 Fonte: INTERREGIONAL HIGHWAYS, 1944. 
- Vias expressas deveriam ter seu traçado paralelo à malha do sistema viário existente, ao invés de encontrá-lo de forma enviesada, ou em curva. Com isso, diversas situações peculiares seriam evitadas ${ }^{32}$.

- Construções paralelas ou elevadas sobre vias férreas eram estimuladas, já que a própria ferrovia já funcionava como barreira e evitava a presença de cruzamentos. Mesmo quando necessários, tais cruzamentos serem elevados, ultrapassando ao mesmo tempo via férrea e expressa ${ }^{33}$.

- Fundos de vale forneciam corredores lineares em direção ao centro das cidades, com topografia controlada, ideal para a construção de uma via de circulação. Além disso, o próprio relatório aponta que esse tipo de situação geográfica abrigou historicamente bairros de construções precárias, ocupados por populações pobres, e mais uma vez as vias expressas eram vistas como oportunidades de reurbanização de regiões consideradas degradadas ${ }^{34}$. Além disso, o curso d'água também funciona como barreira, inibindo a existência de travessias e assim tornaria mais fácil a implementação de vias expressas nesses trechos.

- Limites de parques e grandes quadras industriais também eram recomendadas como áreas a serem destinadas a implementação de rodovias, já que o próprio usos do solo em grandes quadras também reduzia o número de cruzamentos ${ }^{35}$.

O relatório retrata a construção de uma extensiva rede de vias expressas como a única solução para o trânsito no interior das cidades, e aponta para a utilização de áreas públicas, como margens de rios e parques, como corredores de transporte ${ }^{36}$ - assim como Moses fez ao longo da Henry Hudson Parkway, de Nova lorque - por conta do baixo custo da terra e de sua disposição linear.

Os planejadores membros do comitê claramente marcaram a importância de integração dos projetos viários com leis de zoneamento, além de recomendarem a condução do plano de vias expressas por uma autoridade metropolitana. No entanto, não foram feitas recomendações para que o plano de vias expressas fosse compatibilizado com as diretrizes de planejamento urbano municipal. Mesmo assim, é colocado como prioridade máxima de um plano de vias expressas a fluidez e eficiência das rodovias ${ }^{37}$.

\section{AMERICAN ASSOCIATION OF STATE HIGHWAY OFFICIALS (AASHO)}

A AASHO foi também um importante ator na consolidação do conceito de via expressa, através do processo de padronização e normatização de projetos rodoviários. Fundada em 1914, a associação foi responsável pela publicação de diversos manuais, como o de sinalização para rodovias (1927), o de vias urbanas (1929) e o "Manual de Controle de Tráfego Uniforme" (1935) ${ }^{38}$.

34 Nas palavras do relatório, esses locais recebiam "a very low order of development - neighborhoods of cheap, run-down houses and shacks, abject poverty, squalor, and filth". Apud. DIMENTO; ELLIS, $2014:$ p. 64. 
Já em 1936, a partir de um documento elaborado por Joseph Barnett, estabeleceu-se que todos os parâmetros de desenho rodoviário deveriam ser estabelecidos pela velocidade máxima da via". Submetido ao Bureau of Public Roads, em 1944, seu "Interstate Design Standars" especificou pela primeira vez diretrizes de projeto rodoviário, determinando larguras mínimas, padrões de projeto geométrico, tipos de via expressa, distâncias entre conexões e etc. A partir dessas diretrizes, determinadas para a construção de infraestrutura ao longo da paisagem natural, projetos rodoviários poderiam ser modificados de forma limitada ${ }^{40}$. Posteriormente, esses padrões seriam adaptados para a situação urbana, trazendo para a cidade um repertório de elementos construtivos alheio ao espaço urbano.

Tais padrões iam de encontro com o conceito de "Complete Highway" (1943), desenvolvido pela AASHO em parceria com o Highway Research Board. O conceito partia de quatro requerimentos: utilidade, segurança, beleza e economia. A questão estética havia sido colocada com o objetivo de proporcionar uma inserção mais cuidadosa das rodovias na paisagem. Contudo, alguns engenheiros criticavam a medida, alegando que essas exigências drenariam recursos importantes para a sua conclusão. Mesmo assim, o projeto paisagístico se consolidou como parte integrante de uma rodovia, mas em uma posição periférica: ao invés de serem consultados para as principais tomadas de decisão, paisagistas seriam responsáveis apenas pelos acabamentos dos canteiros verdes, cabeceiras de ponte e etc ${ }^{41}$.

Em 1950, a AASHO compila pela primeira vez um apanhado de diversas publicações da associação reunidas em um único livro, intitulado "A Policy on Geometric Design of Rural Highways". Posteriormente, em 1954, o material foi publicado na revista Public Road e incluído num volume denominado "Highway Capacity Manual" (HCM), publicado pelo Ministério do Comércio norte-americano, em 1950". O material acabou sendo difundido mundialmente como manual de projetos rodoviários - atualizado e utilizado até hoje - além de ter sido adaptado para o desenvolvimento de vias expressas em áreas urbanas sob o título de "A Policy on Arterial Highways in Urban Areas", em 1957 $7^{43}$. Para Manuel Herce, o Highway Capacity Manual - como afirma seu nome - tinha viés quantitativo, "um método para calcular quantos veículos cabem numa autoestrada, conforme a demanda que levara a desenhá-la de uma forma específica" ${ }^{44}$. A partir de então, com o vertiginoso crescimento da frota automobilística, os padrões geométricos de desenho baseados na demanda ditaram os principais parâmetros de projetos viários, tornando-se cada vez mais amplos e ocupando mais espaço.

Herce, de forma crítica, aponta como a metodologia de desenho utilizada "lançou mão da matemática, o que the deu a aparência de objetividade, e um instrumental informatizado, difícil de ser contestado e, da mesma maneira, de ser comprovado" ${ }^{45}$. Nesse processo de quantificação das propriedades de desenho das rodovias - afirma Herce - surge uma "liturgia própria", com seu próprio "jargão especializado" e "fora do alcance de outras técnicas" ${ }^{46}$, ou 
seja, a disciplina de desenho viário torna-se área de conhecimento específico dos engenheiros. Assim como os manuais, os primeiros modelos matemáticos para dimensionamento de tráfego surgem também nos anos 1950. O engenheiro Robert B. Mitchell, em parceria com o professor da Universidade de Columbia Chester Rapkin, funda em 1953 a Urban Traffic and Transportation Board, construindo o primeiro modelo de trânsito conhecido, publicando em 1954 o livro Traffic, a Function of Land Use. Pouco depois, em 1956, o engenheiro Alan M. Voorhees publica em Baltmore um modelo semelhante, intitulado A General Theory of Traffic Movement. Através de modelos matemáticos, os engenheiros se diziam capazes de calcular os diversos volumes de tráfego que circulam pela cidade.

\section{LEGISLAÇÃO FEDERAL}

O congresso norte-americano aprova em 1944 - a partir de recomendações do Bureau of Public Roads - o Federal-Aid Highway Act, que designava o "Sistema Nacional de Rodovias Interestaduais" ${ }^{47}$. Com isso, foi possível dar desdobramento práticos aos relatórios elaborados nos anos anteriores. Este instrumento autorizou um significativo aumento de receita destinada a ampliação de capacidade do sistema viário, de vital importância aos planos de ampliação da produção automobilística norte-americana no pós-guerra: setenta mil unidades foram produzidas no ano de 1945, saltando para 2,1 milhões em 1946 e 3,5 milhões em $1947^{48}$.

De acordo com DiMento e Ellis, é a partir desse momento que engenheiros rodoviários são trazidos oficialmente para o debate urbano, antes ocupado somente por arquitetos, planejadores, servidores e engenheiros municipais. Apesar das recomendações de Interregional Highways, a lei promulgada não exigia a integração entre planejamento urbano e rodoviário. O traçado dessas novas vias urbanas tornava-se responsabilidade do Bureau of Public Roads - órgão da esfera federal - e dos departamentos estaduais de rodovias, excluindo do debate urbano os órgãos da esfera municipal. É a partir desse momento que o modelo das parkways do início do século XX dão lugar a uma nova forma de desenho de via expressa urbana ${ }^{49}$. Por serem publicamente aclamadas e consideradas exemplo a ser seguido, as parkways serviam como álibi em favor da construção de rodovias no interior de áreas urbanas, mesmo que estas não compartilhassem de seu cuidadoso modelo de inserção urbana. Afinal, sua implantação exigia largas desapropriações que inviabilizavam sua construção. Ao mesmo tempo, vias expressas elevadas eram cada vez mais tentadoras por conta de seu baixo custo de implementação, além de possibilitarem a passagem dos fluxos urbanos pré-existentes sob sua estrutura. 


\subsection{OTRÂNSITO PEDE PASSAGEM: A VIA EXPRESSA NO NOVO PA- RADIGMA URBANISTICO}

Foi a partir de então que a via expressa se difundiu como paradigma de urbanização. As diretrizes de projetos viários, estabelecidas em esfera nacional durante os anos de guerra, pautaram uma nova forma de se conceber avenidas nas grandes cidades norte-americanas, expandindo o debate entre diversos profissionais. O modelo de via expressa contemplativa das parkways era deixado para trás, assim como a preocupação dos urbanistas municipais com a inserção de vias segregadas em seu contexto. Antes de tudo, era fundamental que fossem atendidas as demandas para que as ruas pudessem absorver maior quantidade de automóveis, tornando possível o tráfego cada vez maior de veículos entre cidades.

O automóvel individual se tornava o principal meio de transporte urbano, tanto do ponto de vista de políticas públicas quanto dos desejos individuais. Sistemas de transporte coletivo de alta capacidade ainda eram mencionados por planos de transporte, porém, em posição periférica.

A transferência da competência sobre a construção de novas rodovias para a esfera estadual - sob a tutela do Bureau of Public Roads - colocou no topo da pauta do projeto viário a eficiência, fluidez e segurança dessas infraestruturas, fundamentais para transformar de uma vez por todas o modelo de urbanização norte-americano. O trânsito nas cidades estava fatalmente aliado ao crescimento espetacular da frota automobilista. Esse novo patamar de volume de automóveis exigia um maior número de faixas de rolamento, pavimentos mais resistentes, curvas mais abertas e, sobretudo, limites de velocidade mais altos, mesmo que isso significasse a quebra de tradições e valores da cidade que pretendia-se salvar. Como afirma Berman ${ }^{50}$, Robert Moses adorava citar a máxima stalinista "não se pode fazer uma omelete sem quebrar os ovos." Afinal - como dizem DiMento e Ellis ${ }^{51}$-, vias expressas urbanas prometiam benefícios óbvios demais para serem questionadas. Apesar do consenso da opinião pública, da indústria e dos governantes acerca da necessidade da construção de vias expressas como solução para o trânsito, a capacidade de financiamento dessas imensas obras ainda não era suficiente para torna-las realidade na maioria dos estados norte-americanos.

É nesse período que a Califórnia toma a dianteira no planejamento de vias expressas urbanas. A cidade de Los Angeles, com uma das maiores taxas de motorização dos Estados Unidos $^{52}$, incorpora com entusiasmo o conceito das vias expressas para seu sistema viário, tornando-se arquétipo da cidade moderna norte-americana ${ }^{53}$. Por conta de sua estrutura urba- 
na descentralizada desde sua origem ${ }^{54}$, Los Angeles se mostrou mais facilmente adaptável às exigências do automóvel, ao mesmo tempo que seu sistema de transporte ferroviário sucateado deu lugar à construção de novas vias expressas ${ }^{55}$. Seu modelo descentralizado se tornou a partir de então referência para outras cidades norte-americanas, desestimulando a concentração das atividades comerciais através de um sistema de circulação comprometido com o automóvel individual.

Já em 1937, o Automobile Club of Southern Califórnia apresentou uma proposta para uma malha de vias expressas regionais para a cidade. Dentre as propostas, a "Motorway Through a Residential District" desenha grandes áreas de transição cobertas de vegetação, que separariam a via construída das casas na sua proximidade. Em uma cidade espraiada como Los Angeles, esse espaço isolaria as residências da poluição e barulho da rodovia. Já a proposta "Motorway through a Business District" fazia o oposto, construindo as vias expressas em conjunto com as edificações ${ }^{56}$. Posteriormente, em 1939, a prefeitura da cidade produz seu próprio plano de vias expressas, tendo como referência os projetos de parkways, mas que posteriormente seriam substituídos por vias com maior capacidade ${ }^{57}$. Foi através do aumento de impostos sobre combustíveis que seu plano pôde sair do papel, concentrando no estado da Califórnia a responsabilidade pelos projetos e pela construção das infraestruturas ${ }^{58}$.

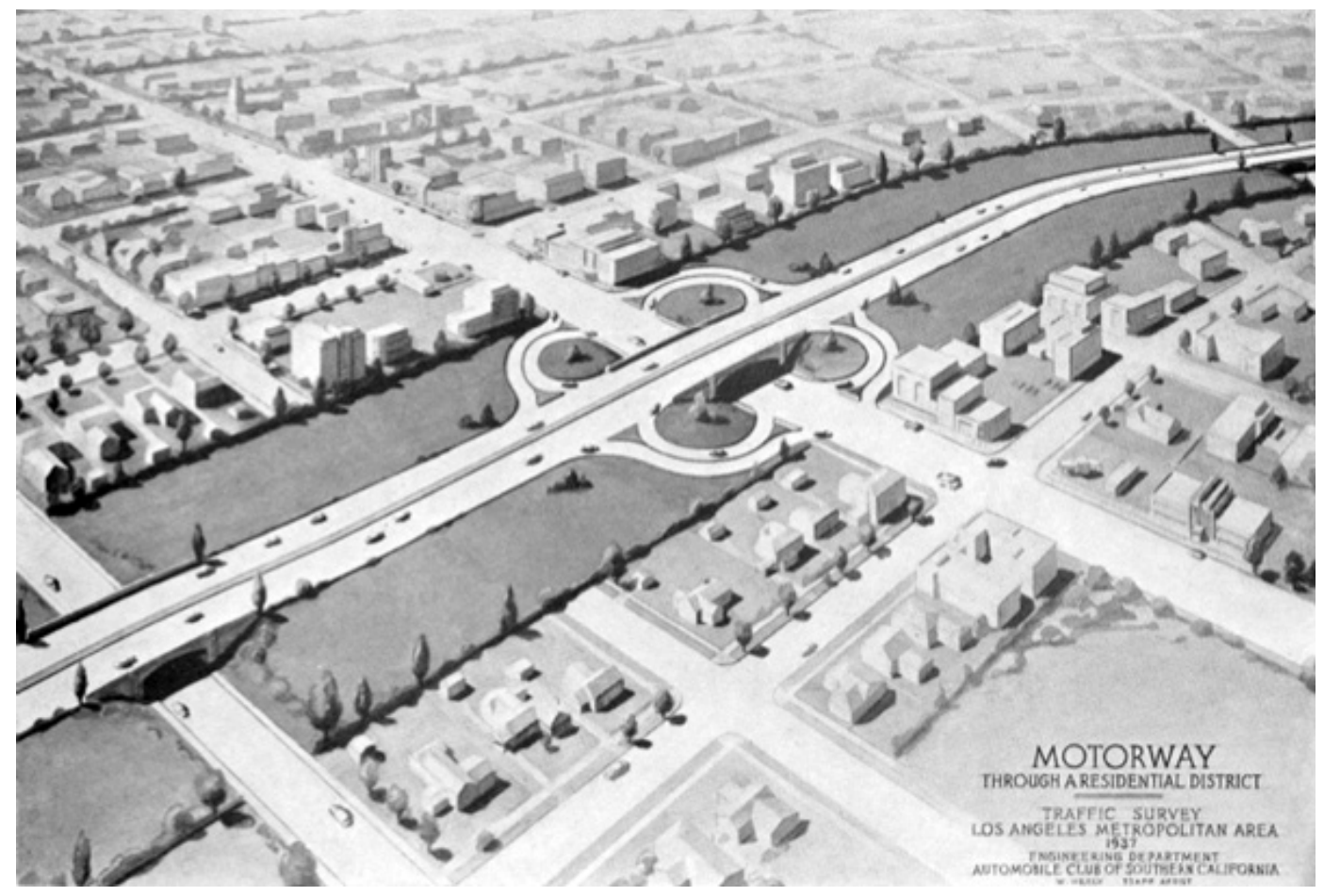

Figura 53 | Proposta de Via Expressa para Los Angeles, $1937^{59}$.

54 De acordo com BOTTLES (1987, p. 04-5), Centralidades urbanas só passaram a surgir no sul da Califórnia a partir do início do século XX, diferentemente de cidades como Boston, Nova lorque ou São Francisco.

55 HALL, 1988: p. 336.

56 DIMENTO; ELLIS, 2014: p. 32.

57 Ibid.: p. 33.

58 BROWN, MORRIS E TAYLOR, 2009: p.34.

59 DIMENTO; ELLIS, 2014: p. 74. 
Engenheiros de rodovias não se enxergavam como urbanistas. O papel das vias expressas no futuro do desenvolvimento urbano de seu entorno ainda não era levado em consideração. Afinal, a tradição de projeto rodoviário em áreas rurais mantinha seu foco principal do acostamento para dentro. De acordo com DiMento e Ellis, a escolha dos traçados rodoviários determinados por engenheiros estaduais partia de embasamentos científicos elementares, sobretudo no atendimento à demanda existente. Através de pesquisas de origem e destino eram estabelecidas linhas de desejo ao longo da cidade, tornando o objetivo das vias expressas a acomodação da demanda existente. Mesmo assim, via de regra prevaleciam as diretrizes dos engenheiros rodoviários, quando confrontadas com as expectativas e planos concebidos por planejadores urbanos municipais ${ }^{60}$. Engenheiros de rodovias ainda não enxergavam naquela época suas avenidas como corredores de desenvolvimento, que posteriormente se tornariam geradores de demanda ${ }^{61}$. Mesmo sem essa pretensão, tais engenheiros seriam responsáveis pelo futuro desenho e ocupação das cidades norte-americanas.

Planejadores e arquitetos passavam a incorporar cada vez mais vias expressas em seus planos. A difusão dos conceitos do urbanismo modernista através da obra de Le Corbusier, bem como a Carta de Atenas resultante do IV Congresso Internacional de Arquitetura Moderna (CIAM), colaboraram para a difusão dos ideais de segregação das atividades urbanas dentro da esfera do planejamento e do desenho urbano a partir desse período.

No plano internacional, os CIAM's buscavam promover as ideias de figuras de força no campo do urbanismo entre arquitetos de diversos países ${ }^{62}$. A Carta de Atenas é um manifesto que tira da análise da cidade conclusões universais, onde sua essência é resumida em pontos precisos que orientariam o urbanismo futuro ${ }^{63}$. De acordo com os seus preceitos, define-se como funcional uma cidade onde suas atividades são claramente separadas. "Habitar, trabalhar, recriar e circular", numa cidade onde as vias de circulação fossem segregadas das demais funções urbanas. Apesar de ser fruto de uma discussão coletiva, a carta apresenta diversas das ideias presentes nos escritos e projetos de Le Corbusier, onde as funções urbanas - como dito - já eram segregadas por tipo de atividade, com destaque à questão do "circular"64.

"a circulação tornou-se hoje uma função primordial da vida urbana. Ela pede um programa cuidadosamente estudado, que saiba prever tudo o que é preciso para regularizar os fluxos, criar os escoadouros indispensáveis e chegar assim a suprimir os engarrafamentos e o mal-estar constante dos quais são a causa, ${ }^{\prime 65}$.

A carta parte sempre da análise dos principais problemas existentes na cidade tradicional, para que, a partir deles, fosse possível apontar soluções. Do ponto de vista da circulação, destaca-se sobretudo a inadequação da rua tradicional às novas necessidades de circulação, bem como as propostas pontuais de alargamento viário das ruas existentes, nos moldes das operações haussmannianas:

65 Trecho de "A Carta de Atenas," Apud. SAKAGUCHI, 1998: p.190. 
"52 - As grandes vias de comunicação foram concebidas para receber pedestres ou coches; hoje elas não correspondem aos meios de transporte mecânicos.

53 - O dimensionamento das ruas, desde então inadequado, se opõe à utilização das novas velocidades mecânicas e à expansão regular da cidade.

54 - As distâncias entre os cruzamentos das ruas são muito pequenas.

55 - A largura das ruas é insuficiente. Procurar alargá-las é quase sempre uma operação onerosa e, além disso, inoperante.

56 - Diante das velocidades mecânicas, o quadro das ruas apresenta-se irracional."166

Em seguida são indicados os preceitos urbanísticos de circulação urbana. As principais diretrizes apontam sobretudo para a primazia da eficiência nos projetos viários, alinhando-se com os preceitos da engenharia rodoviária. Desse modo, a carta endossa conceitos que se tornariam fundamentais na parametrização de projetos viários nas décadas seguintes, como a hierarquização do tráfego, a consolidação dos trevos viários e a separação das vias com elementos vegetativos:

"59 - Devem ser feitas análises úteis, com base em estatísticas rigorosas do conjunto da circulação da cidade e sua região, trabalho que revelará os leitos de circulação e a qualidade de seus tráfegos

60 - As vias de circulação devem ser classificadas conforme a sua natureza e construídas em função dos veículos e de suas velocidades.

61 - Os cruzamentos de tráfego intenso serão organizados em circulação contínua por meio de mudanças de níveis.

62 - O pedestre deve poder seguir por trajetos diversos do automóvel

63 - As ruas devem ser diferenciadas de acordo com as suas destinações: ruas residenciais, ruas de passeio, ruas de trânsito, vias principais

64 - As zonas de vegetação devem isolar, em princípio, os leitos de grande circulação" ${ }^{167}$

A carta, amplamente difundida, absorve muitos dos parâmetros de tráfego trazendo-os para o repertório da arquitetura. Como afirma von Moos, o documento influenciou o urbanismo de forma ambivalente, pois sua contribuição não estaria apenas em suas teses um tanto quanto doutrinárias, mas sim, nas inúmeras discussões acaloradas que ocorreram a partir dela. 
A crença desses profissionais na capacidade inventiva do projeto apontava para a possibilidade de integração entre a cidade e a via expressa tanto em planos para novos bairros e cidades, quanto em centros urbanos tradicionais. $\mathrm{O}$ conceito de anel perimetral ao redor de centros comerciais - como apontado pelos técnicos durante a guerra - fascinava arquitetos e planejadores, que desejavam tornar as ruas centrais exclusivas para pedestres $^{68}$. Mas mesmo apostando na integração das rodovias com o verde, as parkways das décadas de 1930 e 1940 - tão influenciadas por referências do urbanismo City Beautiful não seriam retomadas como exemplo. O urbanismo funcionalista não temia o modelo de vias expressas mais robustas do pós-guerra. Pelo contrário, vias expressas deveriam ser largas e velozes o suficiente para que fossem capazes de comportar toda a demanda de circulação de uma cidade.

Em contrapartida, o apoio dos planejadores e urbanistas às vias expressas era respondido com desprezo pelos mais pragmáticos, responsáveis pelos projetos rodoviários. Como deixou claro certa vez Robert Moses:

"Nós não acreditamos em revolução. A cidade não será demolida e reconstruída em um satélite descentralizado ou qualquer outra teoria acadêmica. Portanto, nós não precisamos esperar pela nova e grande visão do todo constantemente referida pelos planejadores revolucionários" ${ }^{69}$.

O apoio otimista de planejadores e arquitetos à construção de novas vias expressas colaborou com a disseminação desses conceitos não só nos Estados Unidos, mas em diversos países mundo afora. Engenheiros de rodovias tinham no urbanismo modernista e no planejamento urbano amplo apoio à construção de vias de alta velocidade como solução para os deslocamentos urbanos. Porém, em nome da economia e da eficiência, demandas importantes desses profissionais foram em muitos momentos desconsideradas. Vias expressas - sobretudo urbanas - se tornaram em muitos casos responsáveis pela degradação de seu espaço circundante. Em alguns casos - como no Bronx de Marshall Berman e na Avenida São João, em São Paulo - bairros consolidados perderam valor econômico e foram abandonados por sua população tradicional em nome da modernização e da eficiência dos meios de circulação.

\section{TURNPIKES: AS RODOVIAS PEDAGIADAS}

A construção nos Estados Unidos de uma rodovia intercidades, segregada de acesso limitado, só se tornou realidade com a inauguração do primeiro trecho da Pennsy/vania Turnpike, em 1939. Com base no modelo rodoviário europeu, a rodovia possuía duas pistas - uma por sentido, contendo duas faixas de rolamento cada uma - separadas por um estreito canteiro central gramado. Utilizando os túneis abandonados da ferrovia South

68 Durante o debate "How to Rebuild Cities Downtown" - publicado na revista Architectural Forum em junho de 1955 - afirmou-se que "the life-blood of the older center appears to be drained out along evert superhighway." Sugeriu-se como solução a construção de "pheripheral expressways" com estacionamentos de modo a retirar o trânsito de automóveis das ruas do centro. DIMENTO; ELLIS, 2014: p. 99.

69 "We do not believe in revolution. The city is not going to be torn up and rebuilt on a decentralized satellite or other academic theory. Therefore, we do not have to wait for the new, big, overall picture constantly referred to by revolutionary planners."Apud. DIMENTO; ELLIS, 2014: p. 68. 
Pennsylvania - já desativada no período - a rodovia seria uma ótima alternativa às sinuosas e inclinadas rodovias que atravessavam as montanhas do estado de Leste a Oeste. Para financiar o empreendimento, seria cobrada uma tarifa por passageiro, de modo que as obras fossem pagas por aqueles que a utilizassem. De acordo com Mark Foster, a estimativa de tráfego previstas por seus construtores estava por volta de setecentos automóveis por dia. No entanto, o número de motoristas trafegando pelas rodovias expressas nas duas primeiras semanas foi de incríveis vinte e seis mil. Ao final dos anos 1950, a rodovia possuía setecentos e cinquenta quilômetros, a segunda maior do país ${ }^{70}$.

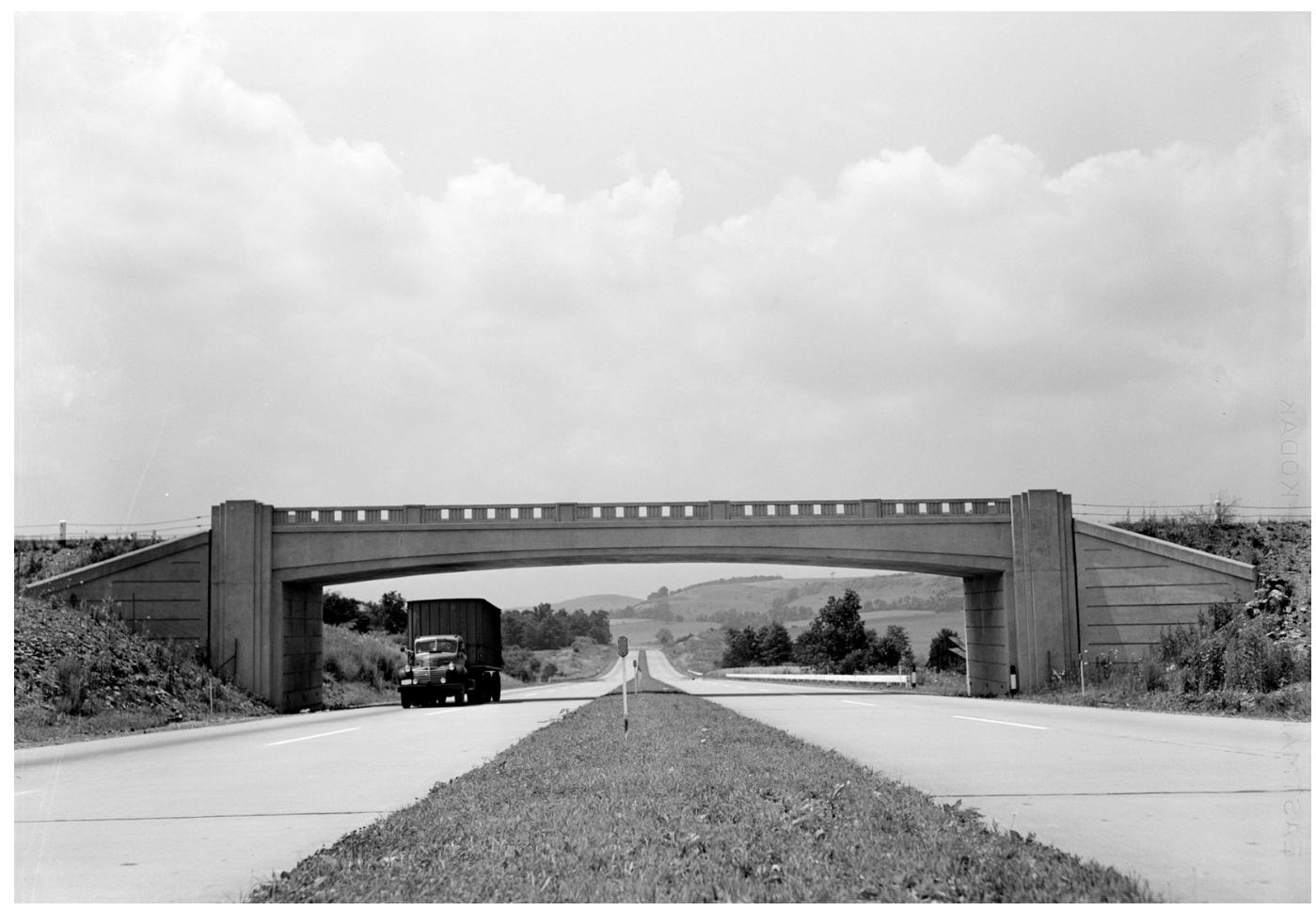

Figura 54 | Pennsylvania Turnpike, 1942

Por conta de todas as facilidades que proporcionava, as turnpikes foram consideradas pelos motoristas norte-americanos as rodovias do futuro, verdadeiras "maravilhas tecnológicas", e se tornaram um grande sucesso. Após o fim da Segunda Guerra, iniciou-se um arrojado programa de rodovias pedagiadas nos Estados Unidos, sobretudo nos estados mais populosos do Nordeste e do Meio-Oeste ${ }^{71}$, até que em 1956 se tornou possível uma viagem de automóvel entre Chicago e Nova lorque inteiramente através de rodovias expressas. Rapidamente os motoristas perceberam que o dinheiro gasto com os pedágios era recompensado através não apenas da rapidez da viagem, mas pela economia de combustível e baixa manutenção dos veículos. Foster nos mostra que por conta das turnpikes, o número médio de frenagens durante esse percurso diminuiu de 890 para 194, enquanto que as mudanças de marcha, em média, reduziram de 3.116 para 777 . Foram construídas nos Estados Unidos cinco mil e oitocentos quilômetros de vias pedagiadas até 1956, quando uma forma definitiva de financiamento rodoviário veio à tona, o massivo financiamento federal propiciado pelo Interstate Highway Prgram. 


\section{FEDERAL AID HIGHWAY ACT, 1956}

A questão do financiamento do sistema de rodovias interestaduais nos Estados Unidos foi finalmente resolvida com a passagem do Interstate and Defense Highway Act - também conhecido como Federal Aid Highway Act -, de 1956. Do ponto de vista do governo federal, o investimento em um sistema interestadual de vias expressas era fundamental. De acordo com o discurso do presidente Eisenhower - que acreditava ter ganho a Segunda Guerra nas Autobahnen alemãs ${ }^{72}$-, a questão da segurança no trânsito era um dos principais motivos que justificavam os investimentos: mais de trinta e seis mil pessoas eram mortas no trânsito por ano, acompanhada por mais de um milhão de feridos, totalizando um cisto anual de 4,3 bilhões de dólares nos custos da época ${ }^{73}$. Somava-se a isso as más condições de manutenção das estradas norte-americanas que encareciam a exportação de produtos; bem como a necessidade de evacuação populacional no caso de um ataque nuclear também justificavam a construção do sistema ${ }^{74}$. O aumento dos congestionamentos - turbinados pelo crescimento econômico e populacional do pós-guerra - também motivavam a construção de vias expressas. Mais uma vez, os interesses comerciais do lobby automobilístico - assim como outras atividades correlatas - foram fundamentais para que houvesse apoio para aprovação do projeto de lei. Como afirma Mark Foster,

"Enquanto as auto-estradas estavam cheias até transbordar durante a hora do rush, muitos dos grupos de interesse voltados para o automóvel não viram outra alternativa a não ser continuar construindo-as. Os lobbies poderosos que representam vários grupos de interesse do transporte de cargas, do automóvel, e de outros fabricantes também trabalharam duramente para ajustar a futura legislação de acordo com o interesse de seus patrocinadores ${ }^{\prime \prime 75}$.

A nova lei forneceu quantias bilionárias para a construção de autoestradas, correspondente $90 \%$ do total, enquanto que o restante do dinheiro seria fornecido pelos estados executores. A origem do dinheiro seguia o exemplo californiano de aumento dos impostos sobre combustíveis, pneus, autopeças e acessórios para carros e automóveis, garantido a verba captada para a construção de rodovias através do Highway Trust Fund. O dinheiro pertencente ao fundo deveria ser investido exclusivamente na construção de rodovias, numa forma mais sofisticada de cobrar dos motoristas pelos investimentos em infraestrutura $^{76}$. As arrecadações eram enormes e durante o período de rápida expansão da cultura do automóvel os valores não paravam de crescer $^{77}$.

72 HALL, 1988: p. 346.

73 WEINGROFF: p. 01.

74 Ibid.: p. 01.

75 "As long as freeways were filled up to overflowing during the rush hour, many of the automobile-oriented interest groups saw no alternative but to keep building them. Powerful, occasionally crude lobbyists representing various trucking, automobile, and other manufacturing interest groups also worked hard to tweak forthcoming legislation to their sponsors' advantage."FOSTER, 2003: p. 107.

76 lbid.: p. 105.

77 lbid:: p. 105. 
Com tamanha verba disponibilizada pelos entes federais, os estados abandonaram projetos de menor escala, menos invasivos, para incorporar suas demandas ao traçado das vias interestaduais, ao mesmo tempo que projetos de transporte coletivo de alta capacidade acabaram no ostracismo ${ }^{78}$. No entanto, para criar um sistema limitado de vias interestaduais, a legislação estabelecia um limite de quilômetros a serem construídos por estado. O resultado dessa medida foi a construção de vias com a maior largura possível, de modo a aumentar a capacidade de carregamento de cada quilômetro construído ${ }^{79}$. De modo a aproveitar a verba empenhada no orçamento, essas vias precisavam ser construídas rapidamente, deixando pouco tempo para planejamento, discussão e posterior avaliação das obras. O impulso em se construir a maior quantidade de vias no menor tempo possível, também impactou os seus traçados. O menor custo das desapropriações também foi utilizado como argumento para a escolha de bairros ocupados pelas populações mais pobres na construção de vias expressas ao redor dos grandes centros urbanos. Assim, garantia-se que maior parte da verba empenhada fosse destinada à construção, e não à desapropriação.

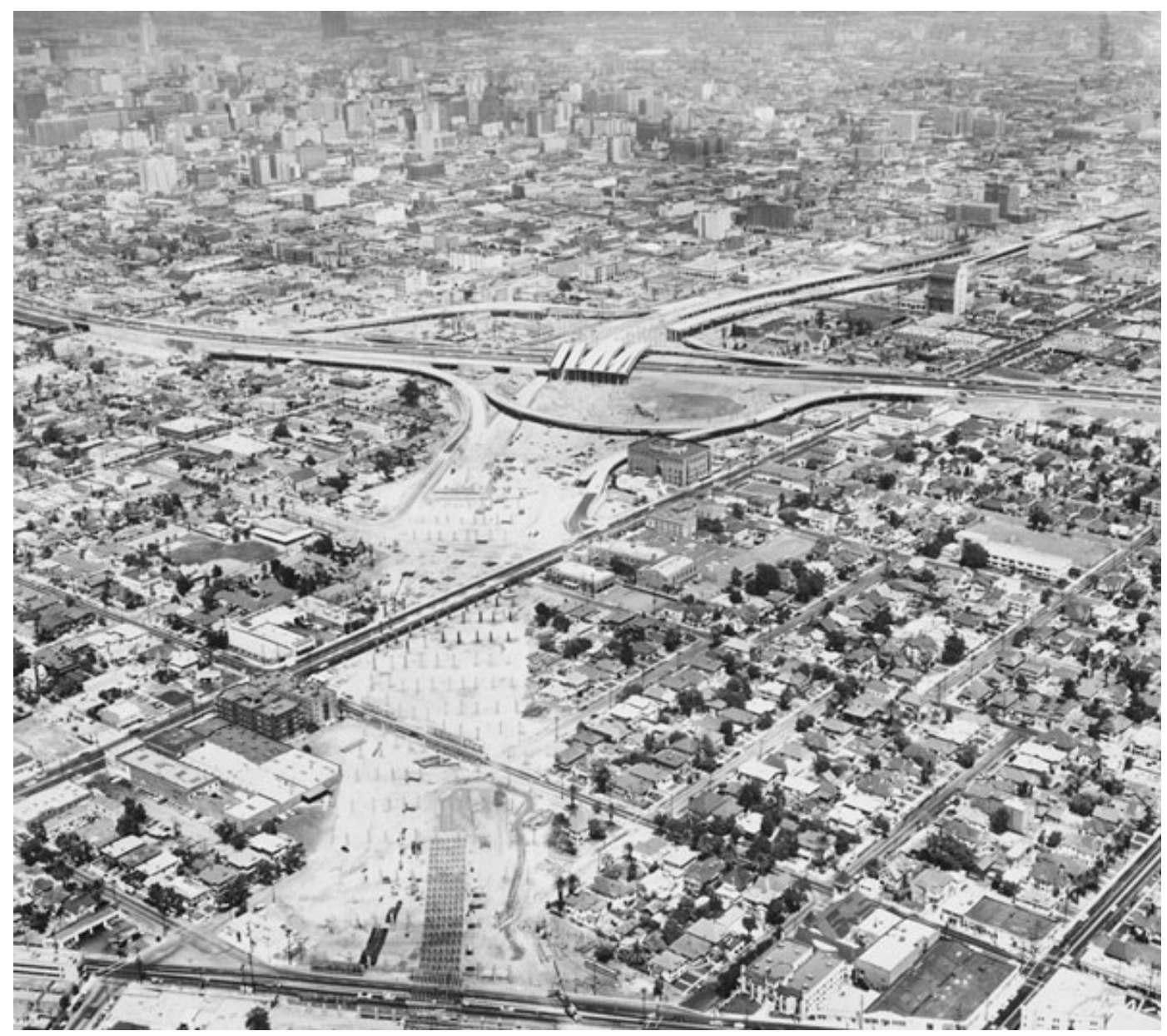

Figura 55 | Santa Monica Freeway (Interstate 10) em construção, Los Angeles, 1961

Como consequência da nova política de financiamento, houve um surto construtivo de vias expressas em larga escala em todo o país. Baseado no desenvolvimento conceitual e tecnológico dos anos anteriores, a construção do sistema de rodovias transformou não 
apenas as cidades norte-americanas, mas também a forma como foi ocupado o seu território, possibilitando o crescimento em larga escala dos subúrbios, tornando o automóvel como única alternativa possível de transporte para grande parte da população. Mais do que construir um sistema que transformou as cidades norte-americanas, elaborou-se nos Estados Unidos entre as décadas de 1940 e 1950 um arsenal técnico e ideológico de soluções em favor do rodoviarismo como modelo urbano de circulação para pequenas, médias e grandes cidades em todo o mundo. Esse surto construtivo continuou ininterruptamente até o início da crise do petróleo em 1973 e ao crescimento das revoltas populares nos centros urbanos afetados.

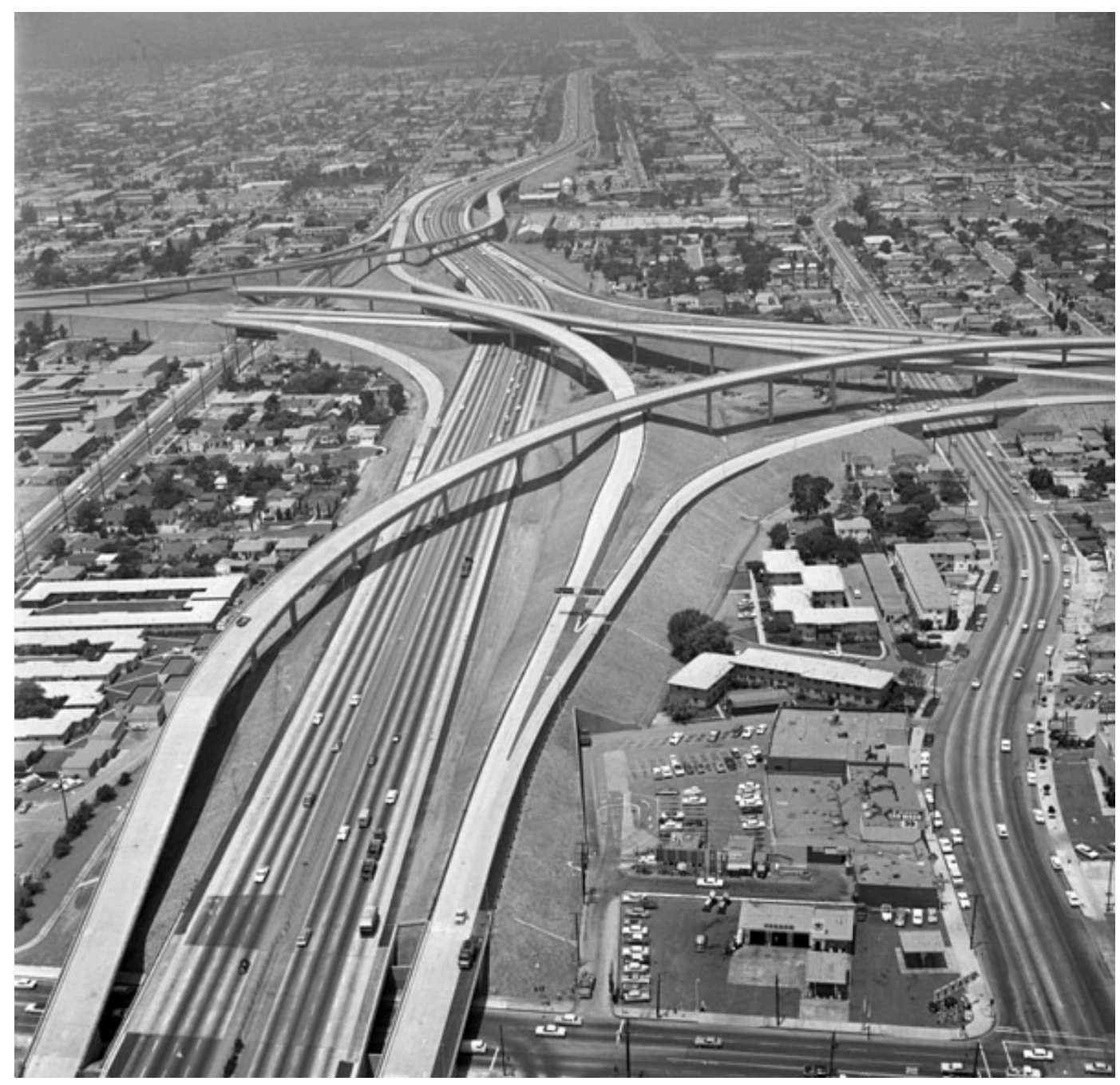

Figura 56 | Santa Monica Freeway (Interstate 10), Los Angeles, 1964 


\subsection{A CULTURA DO AUTOMÓVEL NO SEGUNDO PÓS-GUERRA}

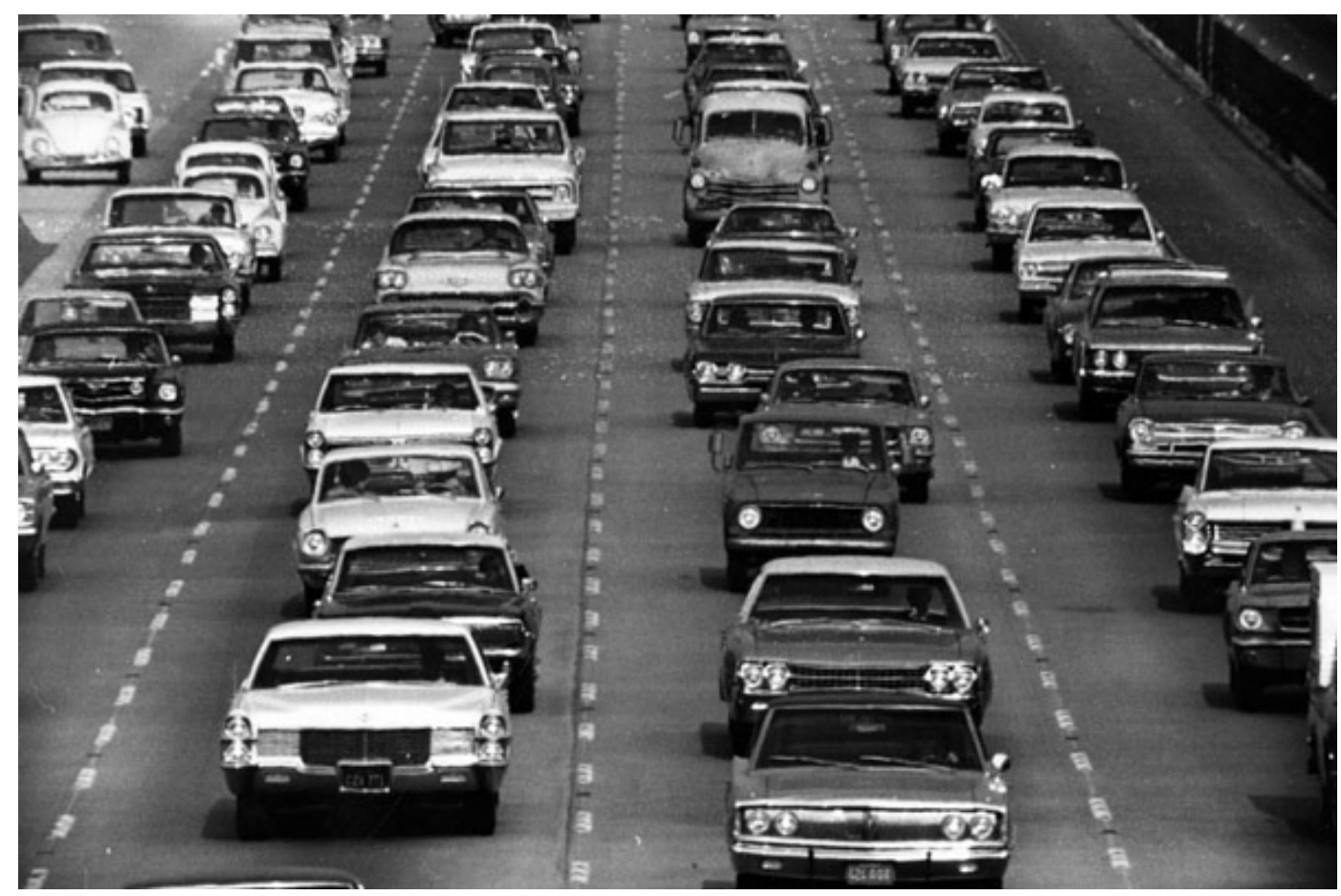

Figura 57 | Santa Monica Freeway (Interstate 10) , Los Angeles, 1970

Tão fundamental quanto o desenvolvimento tecnológico rodoviário, a ascensão da cultura do automóvel nos Estados Unidos foi de extrema importância para a consolidação ideológica das vias expressas mundialmente na cultura urbana da segunda metade do século XX. A estreita ligação entre o automóvel e diversas características da sociedade norte-americana - como o apreço à liberdade individual, sua cultura antiurbana, as longas distâncias percorridas no país e sua relação com a indústria e o desenvolvimento capitalista - tiveram também desdobramentos culturais e sociais naquele país.

Já nas primeiras décadas após o seu surgimento, o automóvel protagonizava diversas canções que se referiam à alegria de dirigir ${ }^{80}$. A mais célebre delas, de acordo com Mark Foster, é a canção "In my Merry Oldsmobile", de Billy Murray, composta em 1909:

Come away with me, Lucille, / In my merry Oldsmobile. / Down the road of life we fly, / Automo-bubbling, you and I.

To the church we'll swiftly steal, /Then our wedding bells will peal, /You can go as far as you like with me / In my merry Oldsmobile. 
Outros reflexos da presença do automóvel na cultura norte-americana também são vistos no cinema e na literatura do início do século. O romance The Great Gatsby, de F. Scott Fitzgerald, constrói um rico panorama da cultura nova-iorquina na década de 1920, mostrando desde os hábitos de uma elite motorizada a trafegar pela Northern State Parkway ${ }^{81}$ - como lembra Berman - até a miséria espacial das "motor slums", desprezadas pelo preservacionista Benton MacKaye. O automóvel tem papel central no romance simbolizando poder e status, como notamos no trecho abaixo:

"Porque o carro é a concreta encarnação desse dinheiro e fonte de poder e mobilidade também, torna-se uma extensão fálica de Gatsby. (...) É o veículo que literalmente traz a sociedade para suas festas e seu emblema de identidade em toda parte" ${ }^{\prime 82}$.

Diversas outras referências ao automóvel são feitas na trama, como o nome da personagem Jordan Baker - remetendo à Jordan Motor Car Company, fabricante de automóveis - assim como o desfecho da história, que gira em torno de um acidente de trânsito.

No entanto, é com o término dos combates da Segunda Guerra e com o fim da recessão econômica que o automóvel se torna elemento fundamental da cultura norte-americana. A produção de automóveis e combustível que foi quase inteiramente direcionada para as batalhas, tornava quase impossível adquirir um carro novo na primeira metade dos anos 1940. Com o fim dos conflitos, os Estados Unidos estavam prontos para pôr fim a mais de 15 anos de recessão.

As transformações da indústria automobilística entre 1945 e 1950 foram notáveis. Após anos de demanda reprimida, a indústria automobilística se preparava para acabar com a lista de espera para compra de veículos, repleta de soldados reformados sedentos por uma vida melhor pós-combates. Vendia-se qualquer produto sobre rodas. No entanto, a recuperação da produção foi lenta. Apenas em 1950 a indústria automobilística foi finalmente capaz produzir automóveis em número suficiente que suprisse a demanda. Finalmente foi possível reverter os baixos resultados de anos de recessão econômica anteriores ao retorno da produção automobilística ${ }^{83}$. Nesse ano estabeleceu-se a marca extraordinária de 6,6 milhões de veículos de passeio produzidos, número oito vezes maior que o de 1945. As vendas cresceriam ainda mais nos anos subsequentes ${ }^{84}$. Entre 1950 e 1970 o número de automóveis nas estradas norte americanas saltou aproximadamente de 40 para 90 miIhões $^{85}$. A importância da indústria automobilística era tamanha que no final dos anos 1960 um em cada sete americanos estavam empregados em negócios com ela relacionados ${ }^{86}$, sem contar que os setores turístico, hoteleiro e alimentício também cresciam no embalo da indústria automobilística ${ }^{87}$. Foi um momento de prosperidade histórico para o país, não

81 BERMAN, 1986: p. 282.

82 "Because the car is the concrete embodiement of that money and source of power and mobility as well, it becomes a phallic extension of Gatsby. (...) It is the vehicle that literally brings society to his parties and his badge of identity everywhere." FITZGERALD, Apud. FOSTER, 2003: p. 28.

83 FOSTER, 2003: p.44.

84 Ibid.: p.44.

85 Ibid:: p.65.

86 Ibid.: p.65.

87 Ibid:: p.65. 
apenas os mais ricos, mas também para a classe operária norte-americana, que ascendeu socialmente: suas famílias deixaram os centros urbanos em direção a subúrbios mais modestos, compraram televisores, um segundo carro, eletrodomésticos e até começaram a enviar seus filhos para a universidade ${ }^{88}$.

Dentre as transformações ocorridas na indústria, o design dos veículos foi uma das mais notáveis ${ }^{89}$. A exuberância do design automobilístico dos anos 1950, de cores fortes e formas arrojadas contrastava com a sobriedade dos automóveis projetados nas décadas anteriores, refletindo o conservadorismo dos consumidores da época. Nesse sentido, merecem destaque as contribuições de designers como John De Lorean, responsável pela linha Pontiac; e Harley Earl, inventor do lendário "rabo-de-peixe", acessório concebido para o modelo Cadillac de 1948 e que virou febre ao longo dos anos 1950. Seguindo o espírito futurista de Norman Bel Gueddes ${ }^{90}$, Earl fascinou-se com o design aerodinâmico dos aviões utilizados durante a guerra, trazendo o desenho dos lemes do caça Lockhead P-38 Lightning, para a traseira do automóvel ${ }^{91}$. Foi um grande sucesso de vendas. Mark Foster chama atenção para a transformação no comportamento do comprador de veículos após a guerra, que buscava veículos grandes e vistosos:

"Talvez os norte-americanos tenham dito que queriam carros seguros, confiáveis e econômicos que durassem por dez anos. No entanto, suas decisões de compra desmentiam suas palavras. Depois de anos de autonegação, depois de uma geração habituada ao transporte econômico e "prático," os consumidores norte-americanos finalmente se sentiram seguros o suficiente economicamente, livres para satisfazer suas fantasias materiais. Os automóveis com rabo-de-peixe exemplificavam esse consumo conspícuo"92.

Alinhados com a brilhante estratégia de marketing da mudança anual de modelo, os executivos das grandes montadoras deram grande liberdade aos designers para que eles pudessem sempre inovar em suas criações, mantendo o público intrigado sobre as novas tendências para o ano seguinte ${ }^{93}$. De repente o público norte-americano não estava mais preocupado com a durabilidade dos automóveis. Pelo contrário, estavam mais preocupados em saber se o modelo do ano anterior já estava obsoleto, pelo menos do ponto de vista da moda ${ }^{94}$. Para Alfred Solan, executivo da General Motors, o crescimento nas vendas dos carros mais "quentes" provavam o "valor dos dólares e centavos gastos com styling" ${ }^{95}$.

Alguns críticos afirmam que o sucesso de vendas desses automóveis era simples resultado da falta de alternativas. No entanto, Foster prova o contrário. Logo após o final da guerra, certos empresários tentaram sem sucesso emplacar a venda de veículos pequenos

\footnotetext{
88 FOSTER, 2003: p.42-3.

89 Ibid.: p. 49.

90 lbid.: p. 70.

91 Ibid.: p. 50.

92 "Americans may have said that they wanted safe, dependable, economical cars that would last for. However, their buying decisions belied their words. After years of self-denial, after a generation of settling for economical, "practical" transportation, American consumers finally felt secure enough economically, free to indulge their material fantasies. Tail fins epitomized conspicuous consumption." FOSTER, 2003: p. 50.

93 Ibid.: p. 70.

94 Ibid.: p. 70 .

95 Ibid.: p. 71.
} 
e eficientes para o público norte-americano. Enquanto a demanda continuava reprimida, até 1948, automóveis compactos obtiveram relativo sucesso. Contudo, a partir de então as vendas caíram drasticamente. Eram os grandes carros que estavam na mira dos compradores ${ }^{96}$.

O automóvel como meio de afirmação social se fazia mais presente do que nunca. A afirmação de Simmel acerca da importância da individualidade para o sujeito moderno, onde" o indivíduo deseja a qualquer preço, diante das forças esmagadoras da sociedade (...) preservar a autonomia e a originalidade de sua experiência" ${ }^{97}$ jamais fizera tanto sentido quanto passou a fazer a partir os anos 1950. Essa necessidade surge por conta do fato de que as relações sociais privam o sujeito moderno de qualquer forma de individualismo, numa "falsa identidade do universal e do particular" ${ }^{98}$. Para Fredrich Jameson, enquanto uns apontam que "esse tipo de individualismo e essa identidade pessoal são coisas do passado, que o velho sujeito individual e individualista está 'morto'," outros, mais radicais, afirmam que "ele é também um mito, algo que nunca chegou de fato a existir" ${ }^{\text {"9 }}$. Essa opressão a qualquer tentativa de individualidade, que nos compele a nos destacar dos demais é condição sine qua non da indústria cultural. Para Adorno e Horkheimer, a participação de milhões na indústria cultural "imporia métodos de reprodução" fazendo com que inevitavelmente "necessidades iguais sejam satisfeitas com produtos estandardizados" ${ }^{100}$. Para os autores,

"produtos mecanicamente diferenciados revelarem-se, afinal de contas, como sempre iguais. Que a diferença entre a série Chrysler e da General Motors seja substancialmente ilusória disso sabem até as crianças "vidradas" por elas. As qualidades e as desvantagens discutidas pelos conhecedores servem tão só para manifestar uma aparência de concorrência e possibilidade de escolha" ${ }^{101}$.

As mudanças ocorridas no design de veículos eram apenas uma pequena parte dessa revolução ainda maior que ocorria com os costumes norte-americanos através do desenvolvimento do consumo de massa e da indústria cultural, onde sem dúvida o automóvel tinha papel fundamental. Talvez nenhum outro elemento cultural norte-americano tenha sintetizado a simbiose entre automóvel e cultura nos Estados Unidos quanto o Rock and Roll. Ao longo dos anos 1950, o ritmo musical embalou diversos motoristas com as canções de Chuck Berry, Buddy Holly, Elvis Presley, Little Richard, Jan and Dean e os Beach Boys, dentre tantos outros que, como os futuristas italianos, exaltavam as possibilidades propiciadas pelos carros em seus versos $^{102}$. Em seu primeiro hit "Maybelline", de 1955, Chuck Berry relata como um corajoso motorista dirigia seu velho carro, emparelhando-o com um possante Cadillac a mais de cento e trinta quilômetros por hora. "Nada vai escapar do meu Ford V8", diz a letra. Antes da fama, assim como tantos outros norte-americanos, Berry tabalhava na linha de montagem de uma fábrica da GM. Após o sucesso, o músico se cercou de veículos, sendo muitos deles Cadillacs, é claro ${ }^{103}$.

Elvis Presley, a maior estrela do Rock and Roll, também tinha raízes humildes. Antes

Vida Mental".

98 ADORNO; HORKHEIMER, 2002: p. 169.

99 JAMESON, 2006: p. 24.

100 ADORNO; HORKHEIMER, 2002: p. 169.

101 Ibid.: p. 171.

102 FOSTER, 2003: p. 65.

103 Ibid.: p. 82-3. 
de alcançar a fama, havia sido caminhoneiro de uma companhia elétrica. Posteriormente, o automóvel se tornou para o cantor o verdadeiro símbolo de seu sucesso. Foster destaca que o simbolismo do automóvel para Elvis representava o sentimento de toda a população: "Elvis, como a maioria dos americanos, viu o Cadillac como a quintessência da aceitabilidade social que até então o iludira"; "sua obsessão com carros refletiu os anseios coletivos de uma geração inteira de norte-americanos anteriormente desprivilegiados" 104 .

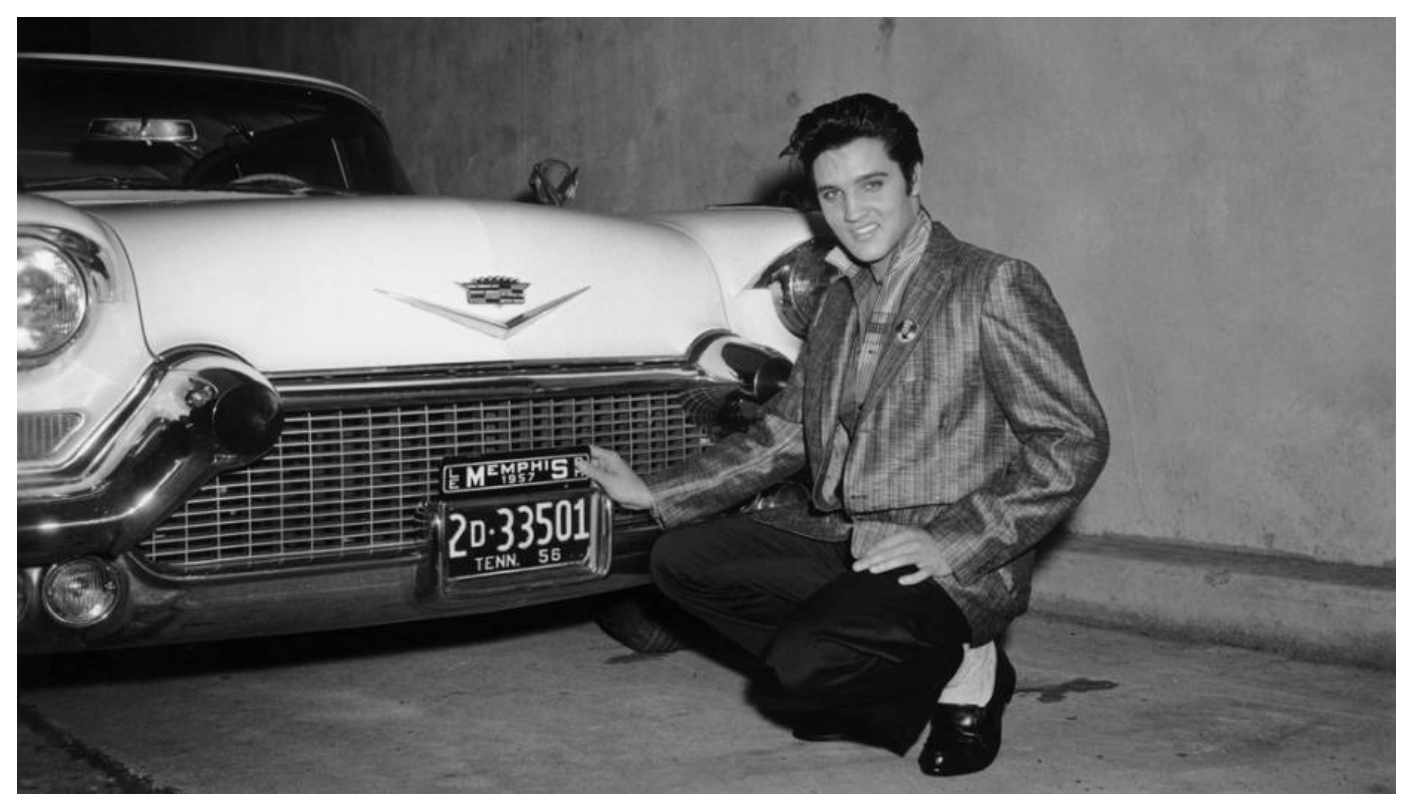

Figura 58 | Elvis Presley com seu Cadillac

O automóvel sem dúvida era um dos principais objetos de desejo da indústria cultural norte-americana, com especial apelo para os joven em busca de "autonomia e originalidade da sua experiência". Reflexos dessa relação podem ser verificados na produção literária e cinematográfica do período. O romance On The Road, de Jack Kerouac, é exemplar do espíritio dessa geração, que canalizava nas viagens de automóvel suas angústias. Para a crítica literária Cynthia Dettelbach, a estrada como descrita no romance, "representava a vida em seu momento mais emocionante" ${ }^{105}$. Talvez o exemplo mais contundente desse espírito seja o clássico filme "Juventude Transviada" ${ }^{106}$, de 1955, estrelado pelo galã James Dean, que retrata o comportamento de um jovem rebelde que explorava ao máximo a emoção e o perigo da velocidade propiciada pelo automóvel. Ironicamente, um mês antes do lançamento do filme, o astro morre em uma batida de automóvel causada por direção imprudente, num ato que poderia ter sido cometido por seu personagem. Sua morte trágica e precoce transformou-o em símbolo de toda uma geração.

Mais do que simbolizar uma cultura, a arte do Pós-Guerra está mais do que nunca associada aos padrões de consumo. Tornou-se critério da produção cinematográfica induzir a identificação entre personagem e espectador, num movimento onde "a vida, tendencial-

104 "Elvis, like most Americans, saw the Cadillac as the quintessence of the social acceptability that had thus far eluded him"; "his obsession with cars reflected the collective yearnings of an entire generation of formerly underprivileged Americans." FOSTER, 2003: p. 84.

105 "the road is life, at its most exciting pitch". DETTELBACH, Apud. FOSTER, 2003: p. 82

106 O título original do filme, em inglês, é "Rebel Without a Cause." 
mente, não deve mais poder se distinguir do filme" ${ }^{107}$, levando à "enganosa substituição do individual pelo estereótipo" 108 . Quantos jovens desse período vestiram suas jaquetas e calças jeans, engomaram seus topetes e aceleraram perigosamente seus veículos nesse processo? Para Adorno e Horkheimer, na indústria cultural a afinidade originária entre negócio e divertimento tem como objetivo a apologia da sociedade; "divertir-se significa estar de acordo" ${ }^{109}$, se adequar. "Divertir-se significa que não devemos pensar, que devemos esquecer a dor, mesmo onde ela se mostra. Na sua base do divertimento planta-se a impotência. É, de fato, fuga, mas não, como pretende, fuga da realidade perversa, mas sim do último grão de resistência que a realidade ainda pode haver deixado" ${ }^{110}$.

A cultura de massa desenvolvida em meados do Século XX tomaria conta dos Estados Unidos, e como se não reconhecesse fronteiras políticas, atravessaria as barreiras culturais para se espraiar pelos quatro cantos do planeta. Como afirmaram Adorno e Hockheimer, "o mundo inteiro passou pelo crivo da indústria cultural" "111. A reboque dessa epidemia, o novo modelo de urbanismo norte-americano seria também difundido fora de seu território, dentro dos mesmos moldes, impactando também fortemente no desenvolvimento das cidades brasileiras. Afinal, como afirmaram os filósofos da Escola de Frankfurt, "toda a civilização de massa em sistema de economia concentrada é idêntica" ${ }^{112}$. É então no bojo do aparato sedutor da cultura de massa norte-americana que a via expressa foi vendida no mundo inteiro como peça fundamental do urbanismo do futuro, repercutindo em São Paulo de forma especialmente contundente.

107 ADORNO; HORKHEIMER, 2002: p. 172.

108 Ibid.: p. 191

109 Ibid.: p. 184-5.

110 Ibid.: p. 184-5.

111 Ibid.: p. 172.

112 Ibid.: p. 169. 




\section{5.}

\section{APONTAMENTOS \\ PARA UMA PAUTA DO \\ URBANISMO CONTEMPORÂNEO}
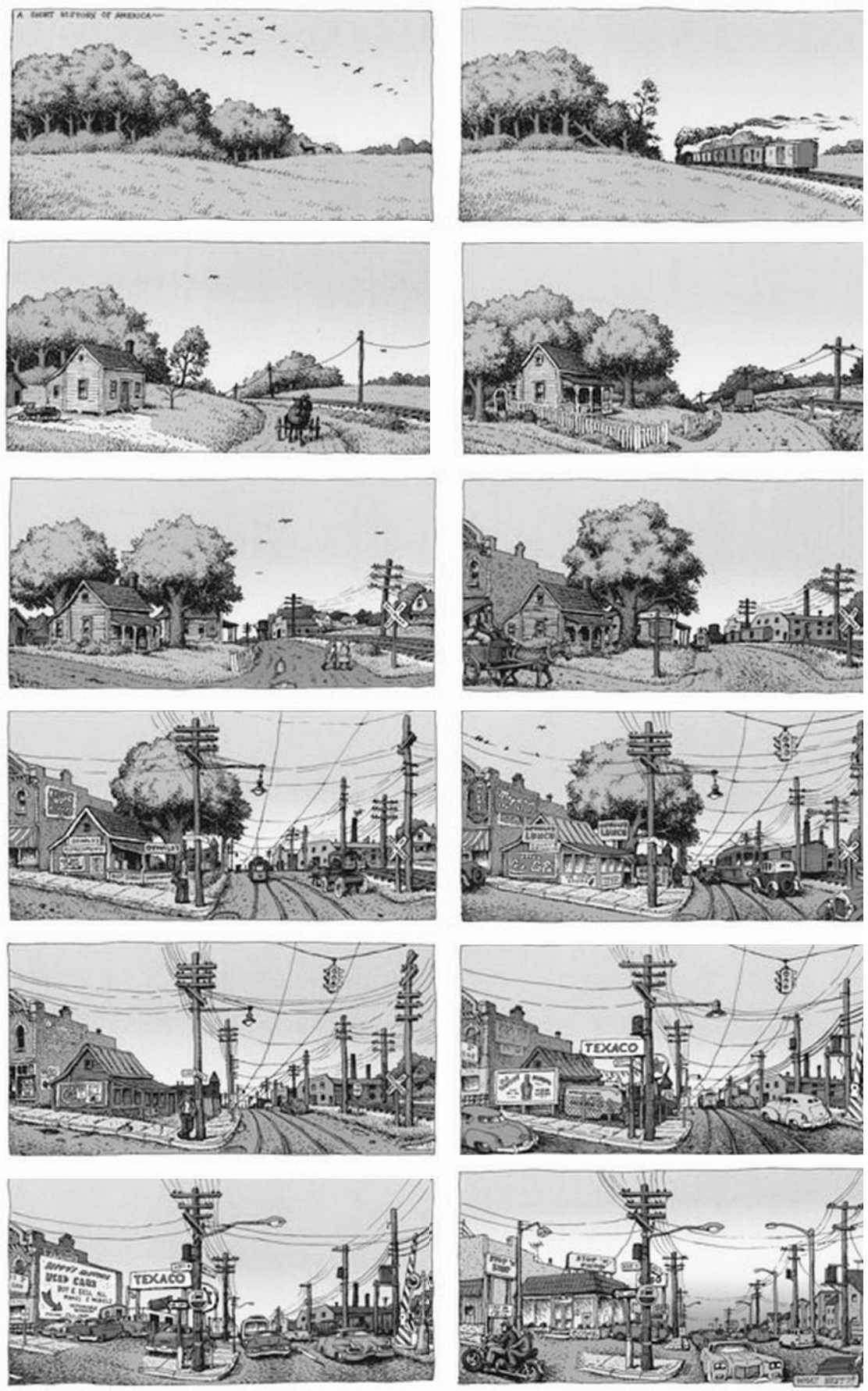

Crumb: A Street History of America 



\title{
5.1. O MITO DO PROGRESSO
}

\begin{abstract}
"Vocês querem, pois, desperdiçar todas as suas melhores forças nessa eterna e inútil admiração do passado, da qual vocês só podem sair fatalmente exaustos, diminuídos e pisados? (...) Nós não queremos mais nada com o passado, nós, jovens futuristas! (...) Empunhem as picaretas, os machados, os martelos e destruam sem piedade as cidades veneradas."
\end{abstract}

F. T. Marinetti. “O Manifesto Futurista", 1909'

A construção de vias expressas, segregadas e com acesso limitado, como solução para o trânsito impactou severamente na conformação urbana das cidades, onde assentamentos urbanos consolidados foram cortados por pesados eixos de infraestrutura, transformando o tecido social ao longo dos lugares por onde passaram. Era o preço a ser pago para que fosse possível desfrutarmos dos benefícios propiciados pelo automóvel: a cidade precisaria mudar radicalmente para acomodá-lo ${ }^{2}$. Como foi mostrado ao longo deste trabalho, 0 conceito de "progresso" foi fundamental para estruturar justificativas favoráveis às transformações na estrutura urbanas. Imbuída de uma conotação positiva, a mudança em direção a um futuro - necessariamente melhor - era considerada inexorável, não havia muito a ser feito. O otimismo é tamanho dentro do conceito que o engenheiro Paulo Maluf, quando prefeito de São Paulo, chegou a agradecer a Deus pelos engarrafamentos da cidade, pois na sua visão "engarrafamento é sinal de progresso" ${ }^{3}$. Berman sintetiza bem esse espírito de otimismo sem escapatória:

"Os fomentadores e adeptos do mundo da via expressa o apresentavam como o único mundo moderno possível: opor-se a eles e a suas obras era opor-se à própria modernidade, fugir à história e ao progresso, tornar-se um Iudita, um escapista, um ser temeroso da vida e da aventura, da transformação e do crescimento. (...) a vasta maioria dos homens e das mulheres modernos não pretende resistir à modernidade: eles sentem sua excitação e creem na sua promessa, mesmo quando se veem em seu caminho.

A Cross Bronx Expressway, que cruzou o Bronx da infância de Marshall Berman, é um claro exemplo desse tipo de intervenção. A obra, realizada entre 1948 e 1972, é um dos grandes símbolos do sentimento de onipotência de Robert Moses, marcando definitiva-

1 In: BERNARDINI, 1980: p. 35.

2 "Crucial freeway planning doctrines were forged during the 1930s and 1940s and garnered widespread support during the 1950 s as cities were aggressively rebuilt to accommodate the automobile." DIMENTO; ELLIS, 2014: p.03

3 Jornal Folha de S. Paulo, 29/02/1996. A sigla PPB denomina o "Partido Progressista Brasileiro". 


\section{IIII}

mente uma mudança de paradigma no desenvolvimento de seus projetos viários, como afirma Renato Anelli:

"Após a Segunda Guerra Mundial, nota-se uma mudança nos parâmetros dos projetos viários coordenados por Moses, que deixavam de ser orientados pela preocupação com a inserção da via no meio construído, para se pautarem pela progressiva preocupação com a eficiência do sistema de circulação e a segurança do ponto de vista do condutor. "A

Ou como descreve Berman:

"Quase tudo que ele construiu após a guerra foi executado num estilo indiferentemente brutal, feito para intimidar e esmagar: monolitos de cimento e aço, desprovidos de visão, nuança ou ação, vedados à cidade circundante por meio de amplos fossos de espaço árido e vazio, cravados na paisagem com feroz desdém por toda a vida natural e humana. Moses parecia agora desdenhosamente indiferente à qualidade humana daquilo que fazia: era mera quantidade - de veículos em movimento" 5 .

Para que a via expressa pudesse cortar a cidade, o projeto ignorou as diversas interferências que encontrava ao atravessar o bairro do Bronx. Além de segmentar a região, a rodovia atravessou rios, montanhas, além de diversas barreiras de infraestrutura, como linhas de metrô, bem como outras instalações subterrâneas. Como nos lembra Berman, Moses minimizava os problemas que seu traçado rodoviário enfrentava:

"Quando você atua em uma metrópole superedificada, tem de abrir seu caminho a golpes de cutelo. Eu vou simplesmente continuar construindo. Vocês façam o que puderem para impedi-lo"6.

Como nas décadas anteriores, os problemas sociais resultantes de uma obra considerada "necessária" eram minimizados, como se em nome do progresso toda mudança fosse positiva.

"Moses tocava numa nota que por mais de um século havia sido vital à sensibilidade dos nova-iorquinos: nossa identificação com o progresso, com a renovação e a reforma, com a perpétua transformação de nosso mundo e de nós mesmos - Harold Rosemberg a denominou "a tradição do novo" (...) Moses estava destruindo nosso mundo e, no entanto, parecia trabalhar em nome de valores que nós próprios abraçávamos "77.

"Com demasiada frequência, o preço da modernidade crescente e em constante avanço é a destruição não apenas das instituições e ambientes 'tradicionais' e 'pré-modernos', mas também - e aqui está a verdadeira tragédia - de tudo que há de mais vital e belo no próprio mundo moderno",8.

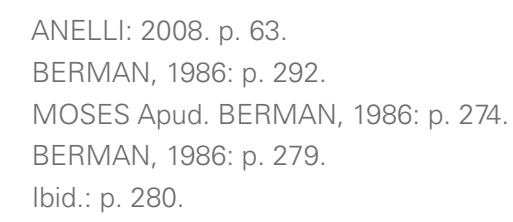


As primeiras reações adversas em relação aos novos rumos dos deslocamentos urbanos não tardaram em surgir. Em meio às transformações da condição urbana norte-americana a partir da década de 1950, o conceito de progresso como algo necessariamente positivo é posto em xeque pelo crítico norte-americano Lewis Mumford, um conservador defensor da vida urbana. Crítico das grandes metrópoles, Mumford via em seu conceito de região a grande saída ao inchaço das grandes cidades. O processo de descentralização das atividades urbanas impulsionado pelo automóvel fora visto com bons olhos por ele e pelos demais membros da Regional Planning Association of America (RPAA) ao longo das décadas de 1920 e 1930. No entanto, ao se deparar com os rumos do urbanismo norte-americano, Mumford critica o modelo de transporte calcado no automóvel e na prática destruidora de construção de rodovias, uma realidade concreta nos anos 1960. Em seu artigo intitulado "The Highway and the City", publicado em 1958, o pensador trata de criticar - como fizera ao longo de sua produção - o conceito de "progresso" resultante do processo de modernização:

"Para a maioria dos norte-americanos, o progresso significa aceitar o que é novo porque é novo, e descartando o que é velho porque é velho. Isso pode ser bom para uma rápida reviravolta nos negócios, mas é ruim para a continuidade e estabilidade na vida. O progresso, no sentido orgânico, deveria ser cumulativo, muito embora uma certa quantidade de lixo seja sempre necessária? Perdemos parte do ganho oferecido por uma nova invenção se descartamos automaticamente todas as invenções ainda valiosas que a precederam" ${ }^{9}$.

O alerta de Mumford trata justamente de combater aquilo que Marx já havia apontado sobre as transformações no espaço urbano resultantes da ação do capital, no que Berman chama de "Autodestruição Inovadora", onde, nas palavras de Berman, "tudo que a sociedade burguesa constrói é construído para ser posto abaixo" ${ }^{10}$ :

"Deparamos aqui com uma estranha dialética, em que um tipo de modernismo ao mesmo tempo encontra energia e se exaure a si mesmo, tentando aniquilar o outro, tudo em nome do modernismo"11.

O Bronx da infância de Marshall Berman compartilhava, até a metade do século XX, de um tipo de modernidade semelhante ao da Paris de Baudelaire, onde o caos resultante da soma de atividades urbanas trazia uma atmosfera ao mesmo tempo caótica e estimulante. Ao cortar o bairro ao meio, a partir da década de 1950, a Cross Bronx Expressway destruía um momento de modernidade em nome do seguinte, como se a modernidade do século XIX estivesse sendo desmantelada para dar lugar à modernidade do século XX. Lewis Mumford, em resposta a essa nova forma de destruição, ataca o modernismo que chegava, e com o qual ele se identificava, o modernismo de sua infância urbana em Manhattan no alvorecer do século XX ${ }^{12}$.

9 "For most Americans, progress means accepting what: is new because it is new, and discarding what is old because it is old. This may be good for a rapid turnover in business, but it is bad for continuity and stability in life. Progress, in an organic sense, should be cumulative, and though a certain amount of rubbish-clearing is always necessary? we lose part of the gain offered by a new invention if we automatically discard all the still valuable inventions that preceded it." MUMFORD, 1963: p. 245.

10 BERMAN, 1986: p. 97,

11 Ibid.: p.159.

12 SWIFT, 2011: p. 235-6. 


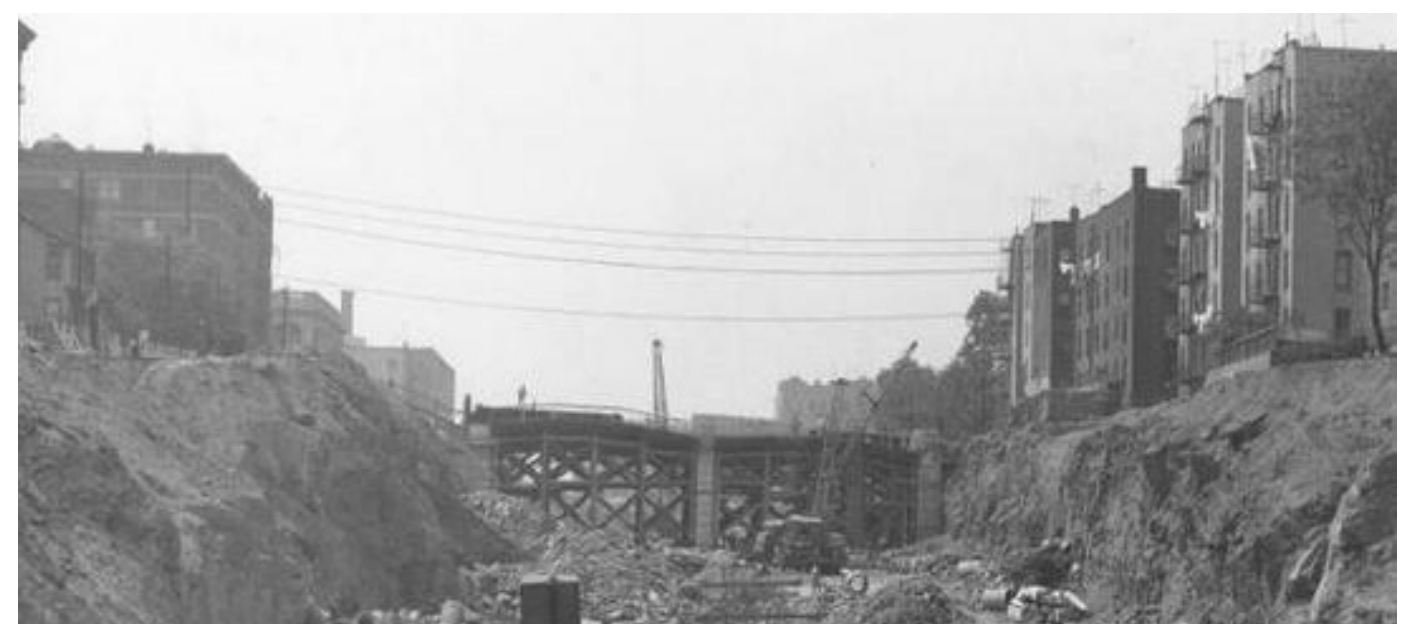

Figura 59 | Obras da Cross Bronx Expressway, 1957

"Talvez nossa idade seja conhecida pelo futuro historiador como a idade da escavadeira e do exterminador; e em muitas partes do país a construção de uma estrada tem aproximadamente o mesmo resultado sobre a vegetação e estruturas humanas como a passagem de um tornado ou a explosão de uma bomba atômica. Em nenhum lugar este hábito em mente é tão desastroso quanto em sua abordagem em relação à cidade. Dado que o engenheiro considera seu próprio trabalho como mais importante do que as outras funções humanas a que serve, ele não hesita em despejar resíduos em bosques, córregos, parques e bairros humanos, a fim de transportar suas estradas diretamente para seu suposto destino" ${ }^{13}$.

O Conceito de "progresso" nos acompanha desde o iluminismo, que parte do conceito de que o homem - e não a natureza - passa a estar no centro das atenções. Pela primeira vez na história, a natureza passa a ter papel coadjuvante, sendo domada para atender aos interesses do homem, como afirmou Marx, citado por David Harvey:

"Pela primeira vez, a natureza se torna para a humanidade mero objeto, mera questão de utilidade, cessando de ser reconhecida como um poder em si mesma; e a descoberta teórica de suas leis autônomas parece somente um artifício destinado à subjugá-las às necessidades humanas." ${ }^{14}$

Assim sendo, descobertas científicas e avanços tecnológicos seriam capazes de afastar os homens de suas origens mais primitivas, para deixar o mundo da barbárie, da religião, do artesanal, do agrário, oligárquico, fragmentado. O novo homem do iluminismo seria transformado: rumaria ao mundo civilizado, da ciência, da máquina, da indústria, da cidade, em uma sociedade laica e democrática, conectada internacionalmente.

\footnotetext{
13 "Perhaps our age will be known to the future historian as the age of the bulldozer and the exterminator; and in many parts of the country the building of a highway has about the same result upon vegetation and human structures as the passage of a tornado or the blast of an atom bomb. Nowhere is this bulldozing habit of mind so disastrous as in the approach to the city. Since the engineer regards his own work as more important than the other human functions it serves, he does not hesitate to lay waste to woods, streams, parks, and human neighborhoods in order to carry his roads straight to their supposed destination." MUMFORD, 1963: p. 247.

14 MARX, apud. HARVEY: 1993, p. 106.
} 
Por trás desse espírito transformador otimista, o conceito de modernização surge intimamente ligado com as necessidades do capital em se multiplicar através do aumento da sua capacidade produtiva e da busca por novos mercados consumidores. Segundo Harvey, Marx afirma que há um princípio unitário que dá forma a esse "distúrbio revolucionário, à fragmentação, e à insegurança perpétua" 15 . Trata-se do que Marx chama de "valor em movimento", ou seja, da característica inerente do capital de estar em constante movimento em busca do lucro. Essa abrupta transformação trazida pelo capital acaba sendo imposta de maneira violenta, passando por cima de valores tradicionais locais, transformando as vidas dos homens e os espaços das cidades, como novamente afirma Marx:

"O capital impele para além das barreiras e preconceitos nacionais e do culto da natureza, bem como [para além] de todas as satisfações tradicionais, confinadas, tolerantes e incrustadas de necessidades presentes e da reprodução de velhos modos de vida. Ele destrói tudo isso e o revoluciona constantemente, fazendo ruir por terra todas as barreiras que impedem o desenvolvimento das forças produtivas, a expansão das necessidades, o desenvolvimento total da produção e a exploração e intercâmbio de forças naturais e mentais." 16

Estamos falando aqui, portanto, de uma substituição. Para que entre o novo, o velho deve sair. Como reparou Mumford, ao mesmo tempo que uma contínua e veloz força progressista nos empurra em direção ao futuro, há um efeito reverso - igual e contrário - de destruição das antigas tradições e organizações sociais. Nesse sentido, Harvey destaca: "A destruição criativa está embutida na própria circulação do capital. O efeito da inovação contínua é desvalorizar, se não destruir investimentos e habilidades de trabalhos passados ${ }^{17}$. No manifesto comunista, de 1848, - segundo Harvey - Marx destaca os aspectos mais agressivos desse processo de transformação: "violência, destruição de tradições, opressão, redução da avaliação de toda atividade ao frio cálculo do dinheiro e do lucro"18. De modo contundente, o excerto do manifesto a seguir também relata a violência com que se instaura o processo de modernização do ponto de vista social:

"Essa subversão contínua da produção, esse abalo constante de todo o sistema social, essa agitação permanente e essa falta de segurança distinguem a época burguesa de todas as precedentes. Dissolvem-se todas as relações sociais antigas e cristalizadas, com seu cortejo de concepções e de ideias secularmente veneradas, as relações que as substituem tornam-se antiquadas antes mesmo de ossificar-se. Tudo que é sólido desmancha no ar, tudo que é sagrado é profanado, e os homens são obrigados finalmente a encarar com serenidade suas condições de existência e suas relações recíprocas ${ }^{\prime 19}$.

Por conta desses aspectos, instaura-se dentro da atmosfera social um clima constante de turbilhão, de instabilidade e insegurança em relação ao que está por vir. A essa condição,

15 HARVEY: 1993.

16 MARX, apud. HARVEY: 1993, p. 106.

17 Ibid.: p. 102.

18 Ibid.: p. 97.

19 Ibid.: p. 97. 


\section{IIII}

na qual o homem imerso nesse processo está condenado, dá-se o nome de Modernidade; uma condição de exacerbação da insegurança, da instabilidade, onde as forças de produção, novos mercados e a necessidades de consumo impostas pela indústria cultural mudam a todo momento. Desse modo, o capitalismo é definido como uma força "permanentemente revolucionária e disruptiva" 20 , ou como conclui Harvey: "A única coisa segura sobre a modernidade é a insegurança" ${ }^{21}$. Já Marshall Berman entende a modernidade como um sentimento ambíguo, numa mistura de euforia e angústia: "Ser moderno é encontrar-se em um ambiente que promete aventura, poder, alegria, crescimento, autotransformação e transformação das coisas em redor - mas ao mesmo tempo ameaça destruir tudo o que temos, tudo o que sabemos, tudo o que somos" ${ }^{22}$.

Dentro da condição imposta pela modernidade, até o próprio conceito de progresso se desintegrou a reboque do desenvolvimento do capitalismo, onde a insegurança em relação ao futuro superou o otimismo. Para Marc Augé, “a ideia de progresso, que implicava que o 'depois' pudesse ser explicado em função do 'antes', encalhou, de certo modo, nos recifes do século XX, ao sair das esperanças ou das ilusões que acompanharam a travessia do mar aberto no século XIX" ${ }^{23}$. Afinal, o fim da barbárie provinda do ambiente natural, prometido pelo progresso iluminista, acaba sendo substituído pela barbárie dos homens, da própria civilização. Para Adorno, a ideia de progresso está relacionada a um indissociável avanço coletivo da sociedade. Para tal, o autor lança mão do conceito de história de Benjamin, que afirmava que "o progresso foi, uma vez, um progresso da própria humanidade (não apenas das suas destrezas e conhecimentos)" ${ }^{24}$. Logo, afirma Adorno:

"Decisiva nisso para a humanidade é a sua constituição social global, enquanto não se forme e intervenha um sujeito global consciente de si. É sobre isso que repousa inteira a possibilidade do progresso, a possibilidade de afastar o desastre extremo, total. Tudo o mais que se refira ao progresso deveria cristalizar-se em torno disso. A carência física, que há muito parecia escarnecer dele, está potencialmente afastada: no estágio atual das forças produtivas técnicas ninguém mais precisaria passar fome na terra. A decisão sobre se persistirão a carência e a opressão - ambas formam uma unidade - repousa inteira no afastamento da catástrofe, mediante uma organização racional da sociedade global como humanidade" ${ }^{25}$.

No artigo "O Mito do Progresso", o pesquisador Gilberto Dupas explicita a construção do conceito de "progresso" como um mito contemporâneo, apropriado pela burguesia na defesa de seus interesses de reprodução do capital. Para Dupas, Merleau-Ponty sintetiza esse movimento ao dizer: "transformar caminhada em progresso é uma elaboração ideológica das elites" ${ }^{26}$. Dupas desenvolve o raciocínio:

"O progresso, assim como hoje é caracterizado nos discursos hegemônicos

HARVEY: 1993, p. 103.

Ibid.

BERMAN: 1980, p.15.

AUGÉ, 1992: p. 27.

BENJAMIN Apud. ADORNO, 1992: p. 219

ADORNO, 1992: p. 218.

MERLEAU-PONTY Apud. DUPAS, 2007: p. 86. 
de parte dominante das elites, não é muito mais que um mito renovado por um aparato ideológico interessado em nos convencer que a história tem um destino certo - e glorioso - que dependeria mais da omissão embevecida das multidões do que da sua vigorosa ação e da crítica de seus intelectuais" 27 .

O autor também admite que evidentemente o desenvolvimento tecnológico trouxe grandes benefícios à vida humana. No entanto, "é inútil tentar atribuir inocência à técnica". "Trata-se aqui de analisar a quem dominantemente esse progresso serve e quais os riscos e custos de natureza social, ambiental e de sobrevivência da espécie que ele está provocando (...). Mas, principalmente, é preciso determinar quem escolhe a direção desse progresso e com que objetivos" 28 .

De modo a justificar sua visão, Dupas lança mão de conceitos desenvolvidos por Habermas em "La Technique et la Science comme 'Idéologie'," de 1968. Para o filósofo, - nas palavras de Dupas - "a racionalização crescente da sociedade estaria ligada à institucionalização da evolução científica e técnica" ${ }^{29}$, onde a racionalidade serviria para cobrir os aspectos exploratórios e repressivos do capitalismo. O desenvolvimento tecnológico resultante das necessidades de incremento produtivo propiciou condições de existência cada vez mais confortáveis aos indivíduos e, consequentemente, o conforto propiciado pelo progresso tecnológico foi capaz de sufocar as questões de classe do capitalismo.

"A legitimação econômica permite ao sistema de dominação adaptar-se às novas exigências de racionalidade. Para Habermas, isso exigiu uma despolitização da grande massa da população, com a opinião pública perdendo sua função política. Para tornar plausível diante das massas sua própria despolitização, surge a ideologia do progresso técnico, no qual ciência e técnica assumem o papel de garantidores da inevitável redenção" ${ }^{30}$.

Talvez nenhum outro produto sintetize o conforto resultante do desenvolvimento tecnológico como o automóvel, o principal sonho de consumo alimentado pela indústria cultural do século XX. Logo, afirma Dupas, que segundo Habermas, é a partir desse momento que a evolução da sociedade parece ser determinada pelo progresso científico e tecnológico" ${ }^{31}$ ao invés das relações sociais e políticas. O conforto que a tecnologia nos proporciona se torna verdadeiro anestésico, a moeda de troca oferecida pela modernidade em contrapartida à instabilidade que ela proporciona. 


\subsection{VIA EXPRESSA E A CRISE DO CONCEITO DE "CIDADE"}

As transformações pelas quais passou o espaço urbano em decorrência do processo de modernização em direção ao capitalismo monopolista foram suficientemente fortes a ponto de romper com o próprio conceito de "cidade", sobretudo nas grandes aglomerações metropolitanas. Regina Meyer afirma que - diferentemente da cidade histórica pré-capitalista - as metrópoles são "indissociáveis da instalação e do desenvolvimento do modo de produção capitalista" ${ }^{32}$. Segundo ela, - a partir da leitura de "O Direito à Cidade", de Henri Lefèbvre "cidade" e "urbano" se tornaram entidades distintas: "o crescimento quantitativo da produção econômica produz um fenômeno quantitativamente novo em termos físico-espaciais, que é o urbano" ${ }^{33}$. Ele encarna, na sua condição de novo fenômeno, a antítese da cidade ${ }^{34}$ :

"A transição de um organismo mais simples - a cidade - para outro mais complexo - o urbano - corresponde, na análise de Lefebvre, à transição de um estágio dominado pela disputa cidade/indústria para um outro onde essa oposição desaparece diante do deslocamento que ambas sofrem frente ao que ele denomina 'problemática urbana',"35

Como em etapas de um processo - afirma Meyer -, o "urbano" só se consolida a partir da dissolução da ideia de "cidade", ou, colocando de forma inversa, "a cidade é a matéria-prima de realização do urbano" ${ }^{36}$. Desse modo, um objeto marcado pela sua tangibilidade -a cidade - se torna, a partir do processo de metropolização, intangível, abstrato. De acordo com a condição imposta pela modernidade, o urbano assume uma forma "em permanente e acelerada transformação" ${ }^{37}$. Como coloca Lefebvre, "redes, fluxos extremamente diferentes se sobrepõem e se mesclam, desde a via pública até o trânsito de informações (...)" ${ }^{38}$. Françoise Choay também chega em conclusões semelhantes sobre às novas dinâmicas urbanas e suas redes de circulação e comunicação:

"A dinâmica das redes de serviços tende, portanto, a substituir a estática dos lugares edificados para condicionar comportamentos urbanos. Um sistema de referência físico e mental, constituído por redes materiais e imateriais, bem como por objetos técnicos, e cuja manipulação põe em jogo um repertório de imagens e informações, ressoa em um circuito que se fecha sobre as relações que mantém nossas sociedades como o espaço, o 
tempo e os homens. Este sistema operativo, válido e factível em qualquer Iugar, na cidade como no campo, pode se chamar de urbano" ${ }^{39}$.

É nesse processo de cisão entre "urbano" e "cidade" que Berman enxerga uma "separação radical entre modernismo e modernização" ${ }^{40}$ que levaria à perda da fé no progresso. $O$ autor identifica a existência de uma estreita relação entre a modernização do meio urbano e o desenvolvimento da arte e do pensamento modernistas até a Segunda Grande Guerra, buscando na condição da modernidade grande inspiração. Segundo ele, nesse momento de transição os artistas deixavam de utilizar o meio urbano como referência principal para sua produção. Assim, Berman conclui:

"essa ausência pode ser tomada como a prova mais notável da pobreza espiritual do ambiente do novo pós-guerra. (...) Ao mesmo tempo, ela devorava a forma sutil, as raízes do modernismo ao segregar a sua vida imaginativa do mundo do dia-a-dia moderno, onde os homens e as mulheres reais tinham que se movimentar e viver" ${ }^{41}$.

Nesse sentido, Flávio Villaça aponta no processo de modernização das cidades brasileiras - em processo análogo ao ocorrido em outras metrópoles mundiais - a transformação dos parâmetros de projeto urbano, deixando de lado questões culturais e sociais em nome dos aspectos econômicos:

"com o crescimento da riqueza do país, com a concentração e centralização crescentes do capital, há a necessidade de obras cada vez mais gigantescas, e as de embelezamento dificilmente teriam porte suficiente para consumir recursos vultuosos. Passa-se assim da 'cidade bela' para a 'cidade eficiente', da cidade do consumo para a cidade da produção"

É dentro dessa lógica que o modelo da via expressa urbana se consolida como realidade das cidades. No caso de São Paulo, esse pragmatismo no urbanismo teve na década de 1950 um momento de inflexão, como Meyer demonstra através da postura de Prestes Maia nesse período. Associado à vertente "progressista" do urbanismo paulistano, "sua única deliberação era adaptar o espaço urbano da 'metrópole do café' de tal forma que a 'metrópole industrial' pudesse instalar-se de forma mais eficiente possível" ${ }^{43}$. Sobretudo na década de 1950, Maia estava comprometido "com o aperfeiçoamento das relações entre a metrópole (espaço físico) e o sistema econômico e produtivo (capitalismo monopolista)" ${ }^{44}$. Consequentemente, ao atender as demandas do capitalismo monopolista, a cidade se torna, de acordo com Castells ${ }^{45}$, não uma vítima, mas um instrumento das forças do capital, verdadeiro agente propiciador. Talvez poucos exemplos sejam tão contundentes para expressar essa relação do que a situação das vias expressas urbanas. Para que

39 CHOAY, Apud. HEREÑÚ, 2016: p. 80

40 BERMAN: 1986. p. 293.

41 Op.cit., p. 293-4.

42 VILLAÇA, 1999: p. 199.

43 MEYER, 1991.

44 Ibid.

45 Anotação de aula expositiva, profa. Regina Meyer, a respeito do livro "A Sociedade em Rede", de Manuel Castells. 
o crescente número de veículos produzidos pela indústria automobilística possa ser absorvido pelo mercado consumidor, cabe a cidade - como agente propiciador - fornecer infraestrutura suficiente para que os motoristas possam trafegar com eficiência pelo espaço urbano. Mais uma vez o caso da cidade de São Paulo é pertinente como exemplo dessa relação, dado que o surto construtivo de vias expressas urbanas alavancado pelo regime militar atende às demandas da indústria automobilística nacional e os interesses do capital estrangeiro.

Nessa oposição entre "cidade" e "urbano", marcada pela perda de tangibilidade da experiência nova em relação à sua precedente, o conceito de "lugar" se torna fundamental. Até a primeira metade do século $X X$, a visão fundamental de desenvolvimento urbano estava enraizada nesse conceito, do ponto de vista físico, econômico e social. Era em torno da tangibilidade desse conceito que orbitava até então o trabalho de planejadores, geógrafos e engenheiros de transporte.

Para o sociólogo norte-americano Melvin Webber - na condição de "lugar" - a cidade era definida como um mecanismo de comunicação entre indivíduos, sobretudo enquanto o contato físico para tal fosse imprescindível ${ }^{46}$. No entanto, para o sociólogo, as modificações no campo da comunicação, seja ela nos transportes ou na telecomunicação, foram fundamentais para transformar o conceito de "cidade", fazendo com que ele se expandisse além das barreiras físicas e sociais dos lugares. É a partir desse momento de derrocada da antiga definição de cidade que Melvin Webber cunha, nos anos 1960, o conceito de "nonplace urban realm", que associado ao conceito de "urbano," é definido de forma abstrata, através de redes de relacionamento de escalas variadas ${ }^{47}$. Desse modo, o foco de seu trabalho deixa o conceito de "lugar" para investigar o conceito de "conectividade" ${ }^{48}$, tanto de maneira mais abstrata, nas diversas formas em que pode ser concebida, até nas reflexões acerca dos grandes centros urbanos. Planejar uma cidade seria pensar as suas redes de comunicação, sua acessibilidade.

Em abordagem semelhante, Marc Augé trabalhou o conceito de "não-lugar" opondo-o ao conceito de "lugar" do ponto de vista antropológico. Para o autor, o conceito de "lugar" estaria relacionado à "construção concreta e simbólica do espaço (...) ao qual se referem todos aqueles a quem ela designa um lugar, por humilde e modesto que seja" ${ }^{49}$. Esses lugares têm pelo menos três características comuns, pretendendo-se "identitários", "relacionais" e "históricos" 50 . Em contrapartida, "um espaço que não pode se definir nem como identitário, nem como relacional, nem como histórico definirá um não-lugar" ${ }^{51}$.

Para Augé, a "supermodernidade" de modo geral é produtora de não-lugares. Ela cria espaços que "não são em si lugares antropológicos e que, contrariamente à modernidade baudelairiana, não integram os lugares antigos" ${ }^{52}$. No entanto, a distinção entre "lugares" e "não-lugares" não é algo claramente determinável, podendo inclusive coexistir: "o primeiro

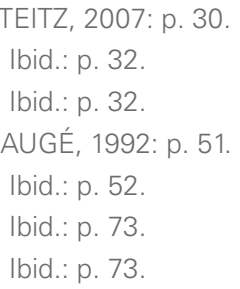


nunca é completamente apagado e o segundo nunca se realiza totalmente" ${ }^{53}$. Enquanto o lugar é o espaço da socialização, o não-lugar é o espaço do indivíduo.

Vias expressas são, para Marc Augé, não-lugares. O fato de estarmos em movimento sobre diversos lugares ao longo de uma viagem rompem nossa relação com o lugar, percebido apenas através de "instantâneos" fragmentados. "A viagem constrói uma relação fictícia entre olhar e paisagem" ${ }^{54}$, tornando o espaço do viajante no "arquétipo do não-lugar" ${ }^{55}$. Segundo o autor, quando viajamos ao longo de uma autoestrada percebemos muitas vezes paisagens "quase aéreas", muito distintas das paisagens das estradas comuns, por estarem distantes da realidade. A experiência com o lugar pelo qual passamos é muitas vezes mediada por uma simples placa, sem que possamos ter contato com as idiossincrasias existentes, estando o viajante "condenado a extrair prazer apenas do conhecimento de sua proximidade" ${ }^{56}$. A rodovia "evita, por necessidade funcional, todos os lugares memoráveis dos quais nos aproxima; mas os comenta" ${ }^{57}$. Em contrapartida, as estradas comuns penetram "na intimidade da vida cotidiana" sendo possível ao cruzar um pequeno vilarejo observar as peculiaridades do local "graças a um sinal vermelho ou a uma diminuição de velocidade que não lhe eram propriamente destinados ${ }^{\prime 58}$.

Nas vias expressas urbanas, a ruptura entre lugar e não-lugar se dá de forma radical. Particularmente no caso das vias elevadas - como o Minhocão - uma laje de concreto separa o não-lugar - via elevada - dos lugares por onde passa. Para Augé, o não-lugar é composto por duas realidades complementares, porém distintas. Seus espaços são constituídos para um certo fim específico, ao mesmo tempo que sua apropriação pelos indivíduos deve corresponder ao seu objetivo principal ${ }^{59}$. Logo, no caso das vias rápidas, o não-lugar se consolida a partir do momento em que automóveis são guiados sobre as pistas dessa infraestrutura designada para esse preciso fim ${ }^{60}$. Numa leitura mais abrangente, é possível também afirmar que, com a chegada do automóvel, a transformação da função social da rua $^{61}$ - de espaço público em infraestrutura, usado primordialmente para a circulação de veículos e pedestres - pode fazer dela um não-lugar. Em contrapartida, todas as atividades que transformam a rua - e por que não a via expressa - em espaço público, utilizando-a para qualquer outra atividade, Ihe devolve o seu caráter de lugar. Nos casos paulistanos do Minhocão e da "Paulista Aberta", basta fechá-los ao trânsito de veículos nos domingos para que as vias percam sua função original e se tornem um lugar por completo. Afinal, como afirma Augé, a distinção entre um lugar e um não-lugar pode ser muito volátil e sutil; "os lugares e os não-lugares misturam-se, interpenetram-se" ${ }^{62}$.

Manuel Herce chama a atenção para o "efeito túnel" que a via expressa cria, tanto no espaço urbano quanto nos lugares que atravessa. Por conta de seus acessos limitados, "a mais-valia urbana gerada é descontínua", ocorrendo apenas em pontos específicos de sua

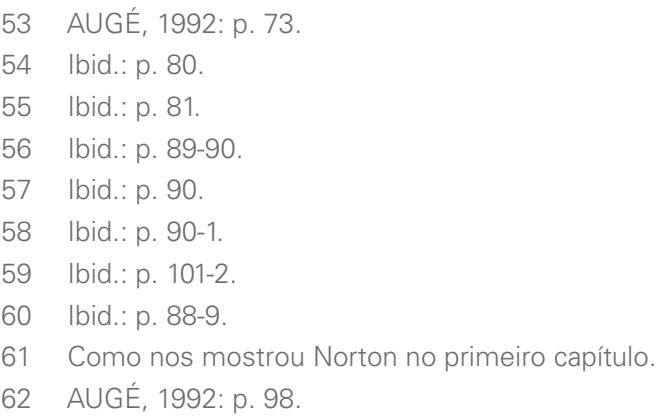


extensão, de entrada e saída, "deixando sem expectativa os espaços intermediários"63. Muitas vezes, além de não serem beneficiados pela passagem de um eixo de infraestrutura, o lugar ainda é afetado negativamente pela sua presença. Como afirma Henri Lefèbvre, "uma autoestrada que brutaliza a paisagem corta, como se fosse uma grande faca, o espaço" ${ }^{\prime 64}$. Em suma, é possível afirmar que a via expressa urbana é um dos grandes emblemas representantes da tensão entre o urbano e o que restou da cidade; entre o lugar e o não-lugar, entre a modernidade de Baudelaire e a supermodernidade.

Contundentes exemplos da tensão mencionada no planejamento das vias expressas urbanas para São Paulo a partir do regime militar, podem ser encontrados. O Plano Urbanístico Básico (PUB), por exemplo, - concebido por técnicos brasileiros e norte-americanos e também conhecido como o "Super-Plano" - propõe uma rede de vias expressas quase abstrata, que pouquíssimo se relaciona com as especificidades da cidade; com suas características físicas, sociais e simbólicas, ou seja, com os seus lugares.

Segundo o próprio relatório, a localização das vias da rede dentro do território não deve ser considerada "precisa" ou "final", devendo ser alvo de posteriores "estudos detalhados" para sua execução ${ }^{65}$. Afinal, a rede viária era de "importância regional" e deveria ser administrada por um órgão metropolitano ${ }^{66}$, ou seja, dada a devida importância ao urbano, a cidade estava em segundo plano. As vias expressas do PUB foram dimensionadas por fatores comprometidos unicamente com a melhor eficiência do próprio sistema, elaborando uma rede de espaçamento regular ${ }^{67}$ em forma de malha - algo nunca antes construído ou sequer proposto para a cidade -, baseando-se nas vias dos rios Tietê e Pinheiros. $\mathrm{O}$ dimensionamento da infraestrutura foi estabelecido de acordo com a demanda, de modo a tornar eficientes todos os quatrocentos quilômetros de eixos rodoviários propostos. Cada via expressa possuiria oito pistas de rolamento, com largura total aproximada de cem metros. As curvas também foram dimensionadas com grandes raios garantindo aos veículos rapidez e segurança em seu deslocamento.

Por outro lado, quando a via expressa do PUB encontra seu entorno, ela se isola completamente. De acordo com os conceitos do seu relatório-síntese, "uma via expressa prejudica menos a comunidade do que uma via arterial com grande volume de tráfego (...)" pois ele é, "até certo grau," "removido do ambiente urbano contíguo." O relatório chega a mencionar a preferência por vias rebaixadas - sem, no entanto, descartar a possibilidade de construção de vias em nível ou elevadas - e aponta para a necessidade de "evitar-se a ruptura de bairros existentes" por onde passam as vias rápidas. No entanto, para se atravessar as pistas com a largura equivalente ao comprimento de um campo de futebol, o plano propõe a construção de "travessias de pedestres a cada quinhentos metros" ${ }^{68}$, perdendo-se completamente a referência da escala do pedestre.

Procedimento não muito distinto foi utilizado nos projetos das vias expressas de fato construídas nesse período. O arquiteto Giancarlo Gasperini, responsável pelo desenho

65 Equipe ASPLAN / DALY-MONTREAL / W. SMITH. Plano Urbanístico Básico - Circulação e Transportes: Recomendações. In. Revista Engenharia Municipal n49, novembro/dezembro de 1970, p. 21.

66 Ibid.: p. 21.

67 Ibid.: p. 22

68 Ibid.: p. 26. 
de diversas infraestruturas de transportes construídas em São Paulo, na década de 1960, - como o complexo viário sobre o Parque Dom Pedro II e a ligação Leste-Oeste - reflete sobre as relações entre "arquitetura e transportes" em sua tese de doutorado, apresentada à FAU USP, em 1972. Logo na introdução ele comenta sobre sua atuação no processo de projeto, afirmando que "embora os problemas técnicos dos sistemas de transportes tenham sido objeto de análises profundas, sob vários aspectos, nunca foram abordados pelos arquitetos os problemas ambientais, que o conjunto das técnicas está criando nas estruturas urbanas (...)" 69 .
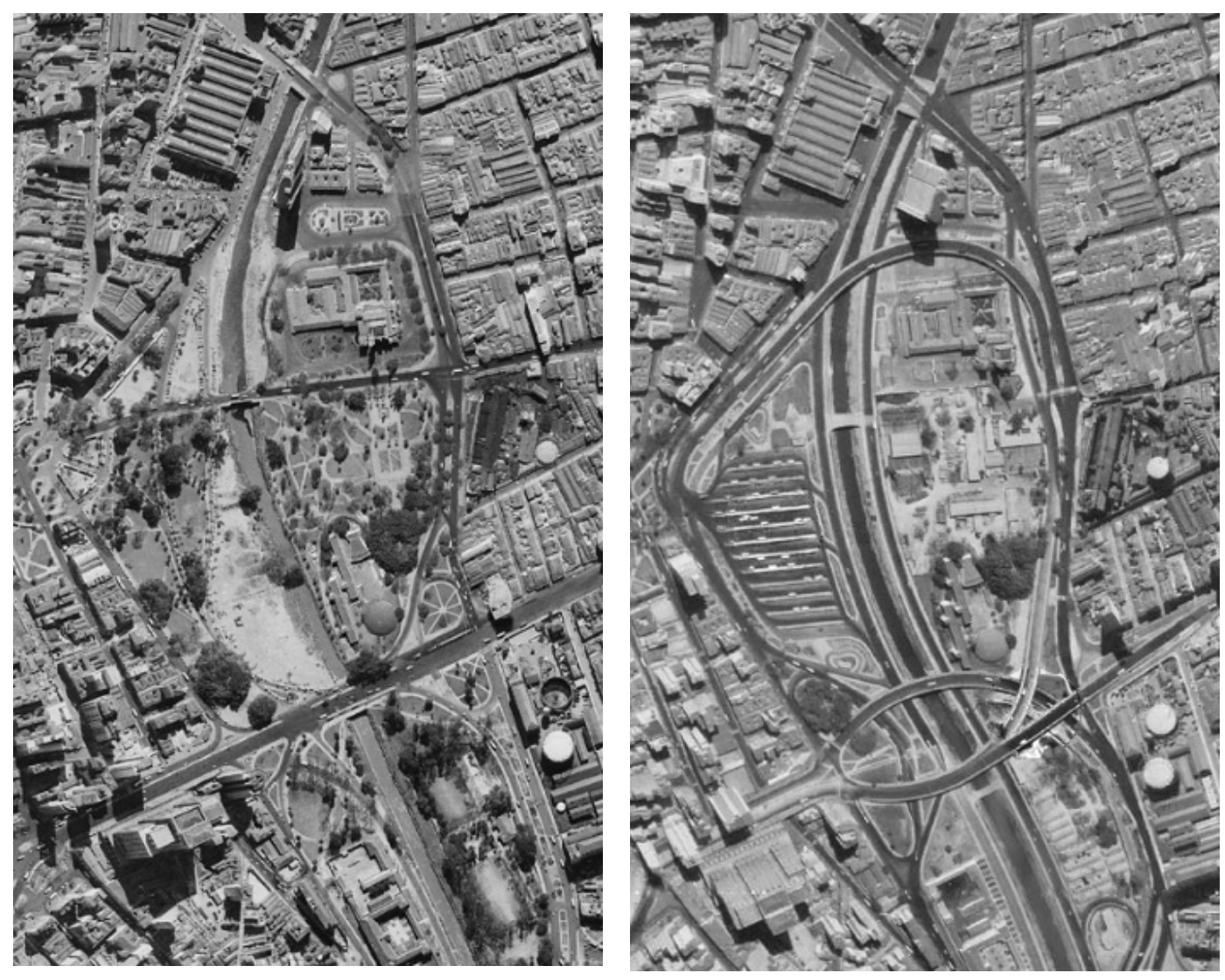

Figura 60 | Duas fotos aéreas do Parque Dom Pedro II, em São Paulo: 1968 e 1974, após a construção da Ligação Leste-Oeste e da Avenida do Estado.

Apesar dos elementos de projeto utilizados por arquitetos e engenheiros serem os mesmos, a ponto de parecerem convergir para um mesmo idea ${ }^{70}$, tais profissionais partiam de visões de cidade muito distintas. As propostas defendidas por arquitetos-urbanistas, com base nos preceitos do desenho urbano modernista, aliavam vias expressas segregadas de acesso limitado a criação de grandes espaços públicos verdes, destinados ao pedestre e desprovidos de função específica. Tal descrição espacial poderia facilmente ser confundida com as modernas autoestradas com canteiros centrais gramados preconizadas por engenheiros de rodovias, que pretendiam apenas evitar que as atividades urbanas atrapalhassem o fluxo de veículos. A apropriação das vias expressas dos engenheiros pelos arquitetos,

69 GASPERINI, 1972: p. 05.

70 Assim como debatido neste trabalho, a professora Regina Meyer também aponta para esse alinhamento na forma de uma "visão comum da metrópole moderna" entre o pragmatismo nova-iorquino e o urbanismo moderno de Le Corbusier e Sigfried Giedion, sobretudo em relação à circulação urbana. MEYER, 1991: p. 88-9. 


\section{IIII}

encampada por Le Corbusier, funcionou como um verdadeiro "Cavalo de Tróia" perante as boas intenções do urbanismo modernista: enquanto as vias expressas segregadas eram imprescindíveis ao projeto urbano moderno, a qualidade do espaço circundante à rodovia era uma preocupação secundária - e muitas vezes inexistente - para os engenheiros rodoviários; um mero resíduo frente aos interesses de ampliação da fluidez do tráfego, tão claramente representado pelo Parque Dom Pedro II, em São Paulo.

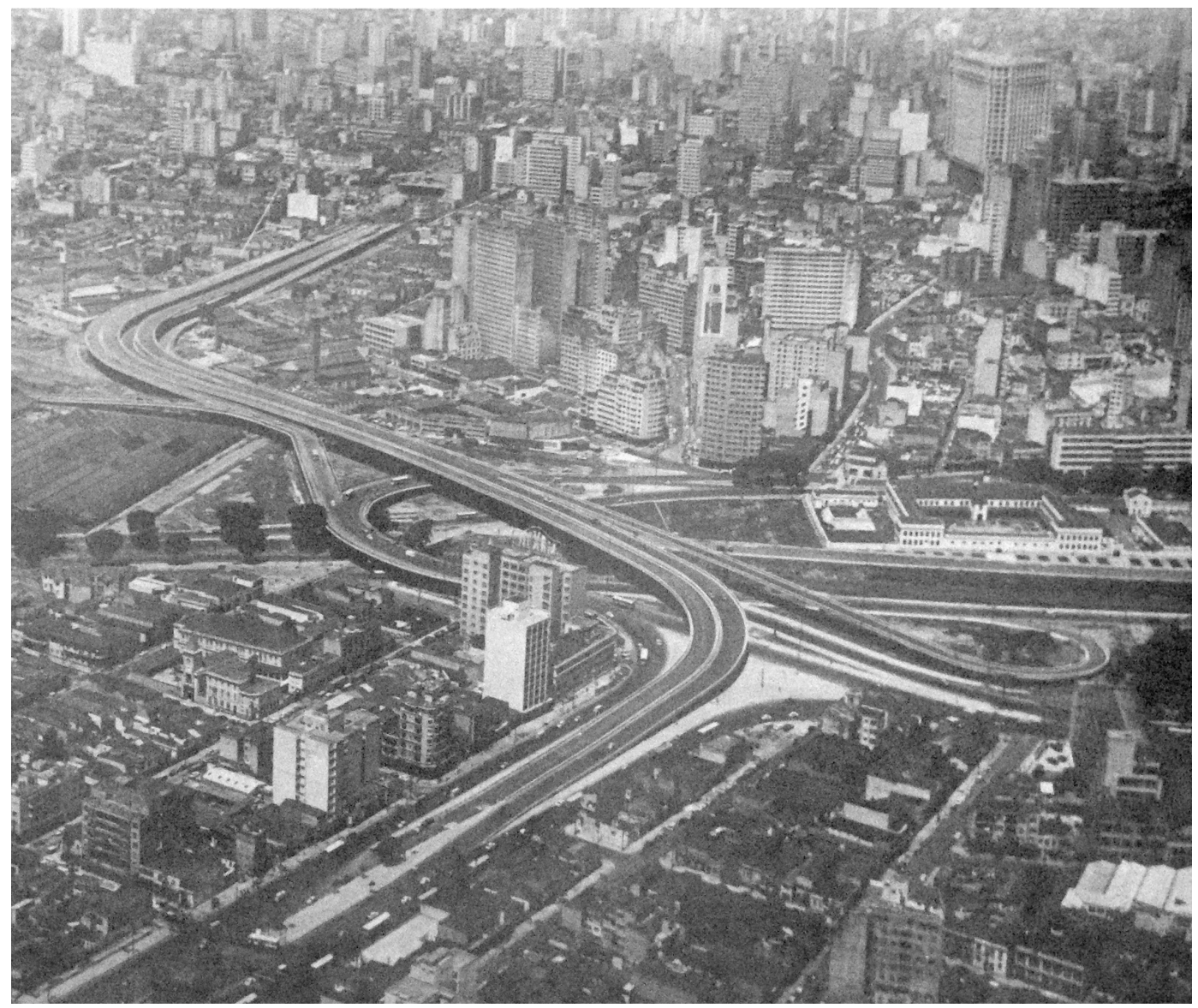

Figura 61 | Corredor Leste-Oeste, trecho sobre o Tamanduateí

Para o arquiteto Rem Koolhaas - em seu ensaio "Junkspace" ${ }^{71}$ - o espaço resultante desse planejamento viário tecnocrático encampado pelos engenheiros de rodovia acaba se tornado um mero resíduo, um "espaço-lixo":

"O espaço-lixo é o que resta depois da modernização seguir seu curso, ou mais concretamente, o que se coagula enquanto a modernização está em marcha, o seu resíduo ${ }^{\prime \prime 2}$.

Desse modo - como já apontava Mumford, nos anos 1950 -, apesar de funcionarem perfeitamente para atingir seu objetivo como agente propiciador das forças do capital, as vias expressas urbanas em contato com a escala local - assim como tantos outros espaços da cidade - podem se tornar de fato resíduo, sem se adequar às necessidades humanas.

71 Traduzido na versão em português para "Espaço-Lixo"

72 KOOLHAAS: 2013, p. 69. 
Ao analisar a história do planejamento e construção de vias expressas, fica claro que infraestruturas de grande escala como essa exigem grande concentração de dinheiro e poder para saírem do papel. Como demonstrado neste trabalho, mesmo em países ricos da América e da Europa, o financiamento bem-sucedido das infraestruturas precisou de grande apoio federal, orquestrado por iniciativa política de governos com amplo poder como nos regimes autoritários de Hitler e Mussolini na Europa, na presidência do popular ex-combatente Eisenhower nos Estados Unidos e no regime militar brasileiro. Fica claro no exemplo norte-americano - única democracia dentre os exemplos citados - que o rápido surto construtivo de rodovias urbanas só se viabilizou ao excluir do debate os agentes da escala local: prefeituras, sociedade civil e comunidades afetadas. A via expressa - sobretudo urbana - torna-se, portanto, um dos maiores símbolos do autoritarismo em favor do capital nas nossas cidades, urbanizando-as "de cima para baixo".

Porém, na condição de espaço-lixo, a via expressa cai num paradoxo. Ao mesmo tempo em que construções de tamanha infraestrutura exigem poder político, econômico, grandes esforços de planejamento e obras demoradas, sua construção é justificada por motivos dos mais imediatistas, destinada a suprir demandas de viagem que estão em constante mutação. Esse processo de transformação está diretamente ligado à transitoriedade dos fluxos de capital que se movimentam cada vez mais, com imensa rapidez ao redor do globo, superando em muitas vezes a velocidade de planejamento e construção de obras de grande porte. Como resultado, vemos muitas vezes acontecimentos inesperados, onde redes viárias recém-inauguradas se mostram sub ou superdimensionadas. Afinal, quando estão prontas, as vias atendem a demandas de uma realidade ultrapassada, do tempo em que foram concebidas. De todo modo, como aponta Koolhaas, a mudança divorciou-se da ideia de melhoramento. Não há progresso, o espaço-lixo se desenvolve em todas as direções. A única certeza é a remodelação: "já há mais espaço-lixo em construção no século XXI do que o que sobreviveu no século $X X^{\prime \prime 73}$, ou como afirma o autor, com a ironia que lhe é particular, "mais importante do que o projeto das cidades será o projeto da sua decadência" ${ }^{74}$.

73 KOOLHAAS, 2013. p. 70.

74 "More important than the design of cities will be the design of their decay". KOOLHAAS, Rem. Imagining Nothingness, p. 199-202. In KOOLHAAS, 1995. 


\subsection{VIA EXPRESSA COMO SOLUÇÃO PARA O TRÂNSITO}

O trabalho também nos mostra - sobretudo através da pesquisa de Peter Norton o papel do lobby automobilístico no convencimento da sociedade norte-americana - e posteriormente do mundo todo - acerca da viabilidade da utilização do automóvel como meio de transporte em larga escala, dentro e fora das cidades. Mesmo com as uníssonas críticas de engenheiros de tráfego a um modelo de transporte já saturado nas cidades norte-americanas da década de 1920, representantes dos interesses da indústria automobilística foram capazes de convencer a sociedade do contrário. Habilmente, o lobby automobilístico sustentou a tese de que o problema da congestão urbana seria resolvido dando mais espaço para os carros na cidade. Como forma de aumentar a capacidade das vias, também seria necessário aumentar a velocidade de circulação das pistas. Em nome do progresso, homens e mulheres do século XX foram convencidos de que a cidade deveria se adequar ao transporte, e não o contrário. Manuel Herce também nos mostrou que, a partir dos anos 1950, modelos matemáticos informatizados foram utilizados de maneira ideológica para dimensionar vias expressas de porte cada vez maior, num modelo "difícil de ser contestado e, da mesma maneira, de ser comprovado" ${ }^{75}$. Afinal, como diz Stan Allen em "Infrastructure Urbanism" - citando Foucault -, "técnicas são sociais antes de serem técnicas" ${ }^{76}$.

Hoje comprovadamente sabemos que o problema do trânsito não é simples resultado de falta de capacidade viária. Modelos matemáticos alternativos e até estudos sobre experiências concretas foram capazes de mostrar como a construção de mais vias pode, em alguns casos, até piorar a situação do trânsito. Ademais, comparando a densidade de diferentes metrópoles com as formas de deslocamentos motorizados mais utilizados em seu território, podemos notar que vias expressas rodoviárias só se tornaram canal principal de circulação individual em cidades com baixa densidade média. Ou seja, para universalizar o automóvel como meio de transportes nos Estados Unidos foi necessário não apenas expandir o espaço de circulação, mas a cidade como um todo.

Estudo realizado pela London School of Economics (LSE), dirigido por Philipp Rode e Graham Floater, intitulado "Acessibility in Cities: Transport and Urban Form", de 2014, comparou em cidades com população semelhante a divisão modal de viagens motorizadas com o tamanho de suas manchas urbanas. Em cidades muito densas, como Hong Kong, na China, (10.110 hab/Km²), a divisão modal em viagens motorizadas mostra predominância absoluta do transporte coletivo. Enquanto apenas $7 \%$ das viagens são feitas através de automóvel individual, os $93 \%$ são realizadas com transporte coletivo. Já em cidades de baixa densidade como Atlanta, nos EUA, (580 hab/ $\left./ \mathrm{Km}^{2}\right)$, a divisão modal se inverte em favor do transporte individual ( $92 \%$ para o transporte individual e $8 \%$ para o transporte 

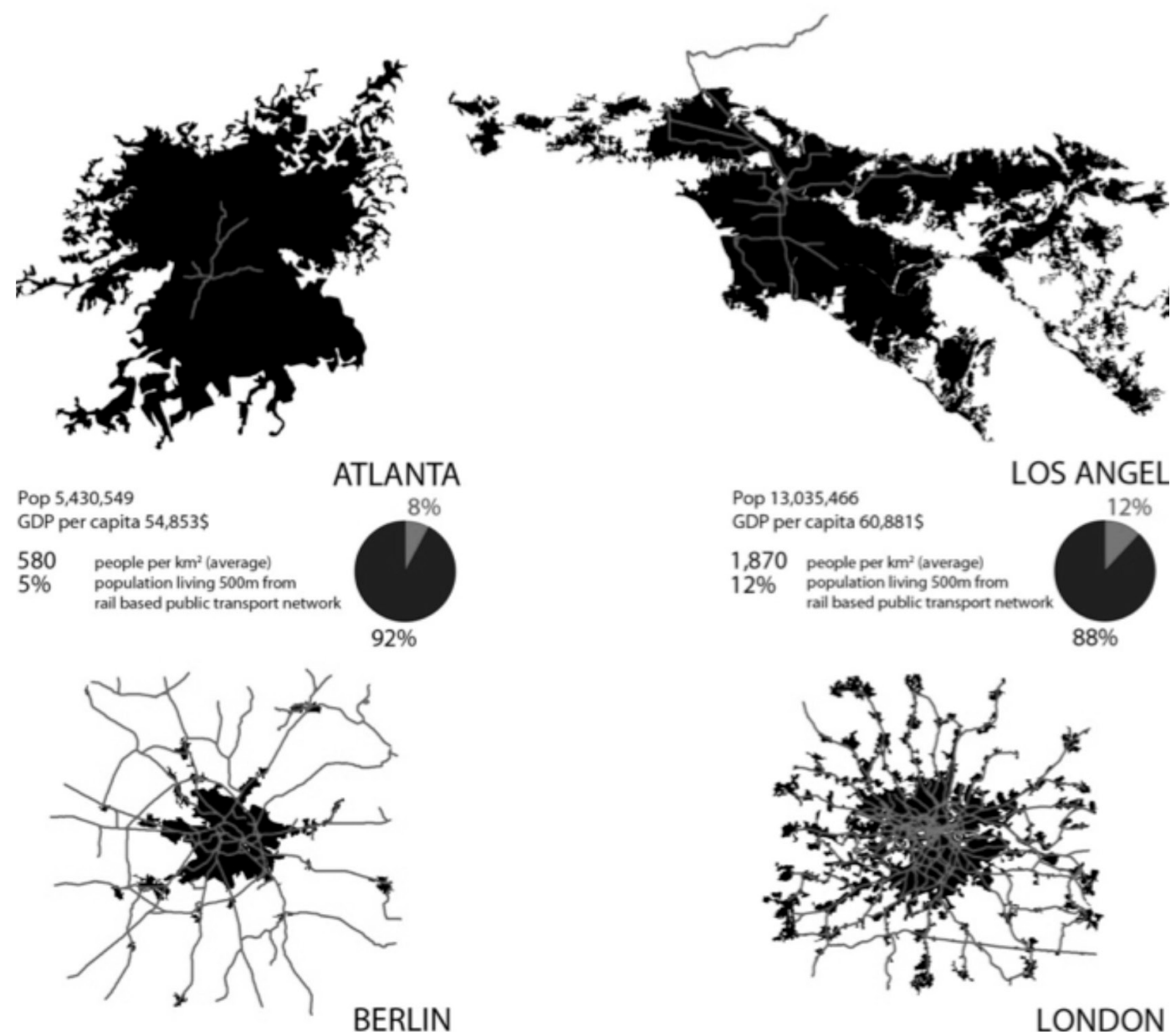

BERLIN

GDP per capita $37,147 \$$

3,930 people per $\mathrm{km}^{2}$ (average)

$33 \%$ population living $500 \mathrm{~m}$ from rail based public transport network
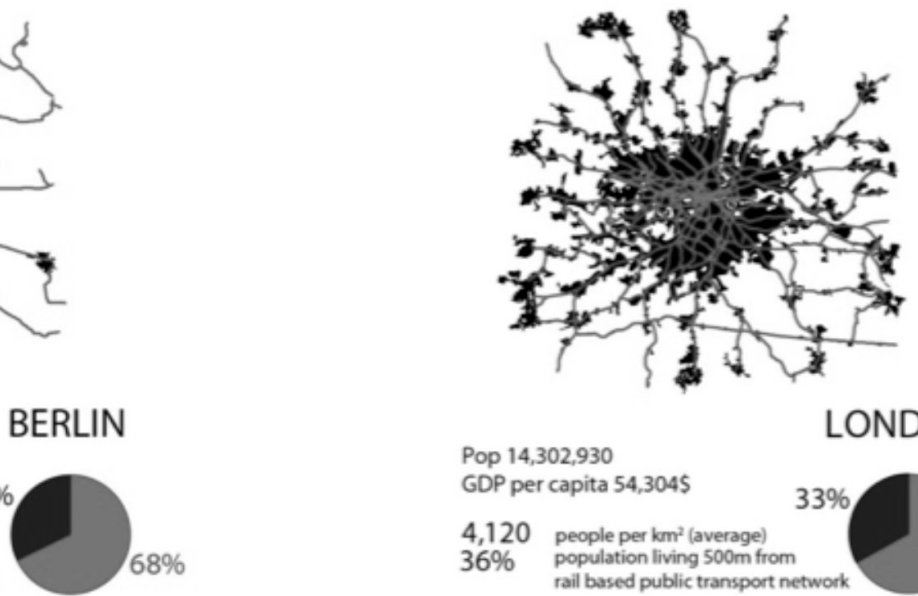

Pop $14,302,930$

GDP per capita 54,3045

4,120 people per $\mathrm{km}^{2}$ (average)
$36 \%$
population living $500 \mathrm{~m}$ from

LONDON
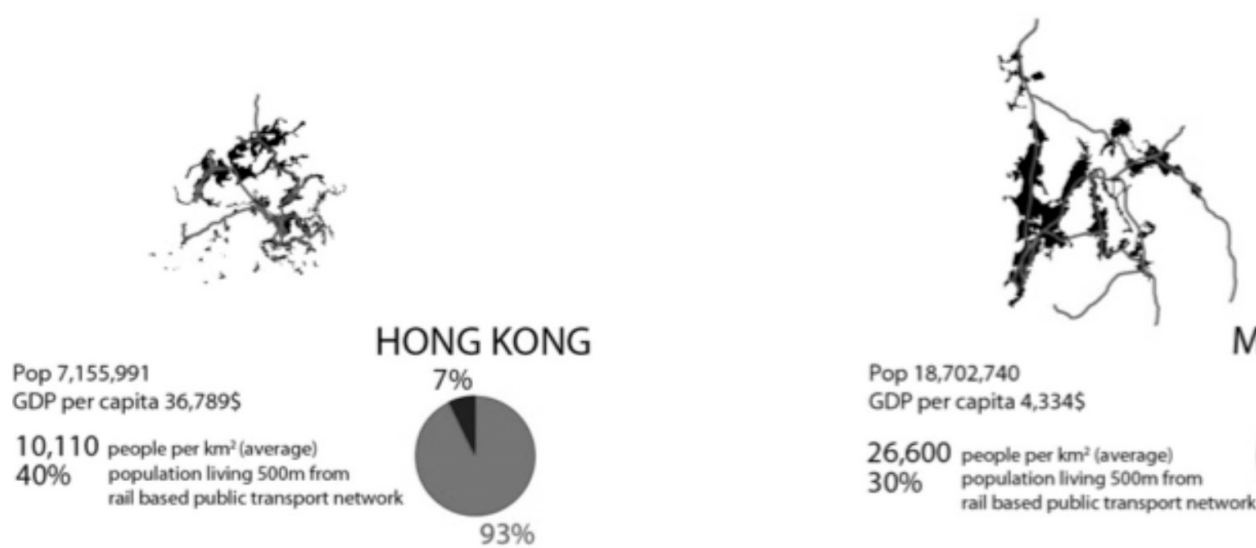

Pop 18,702,740

GDP per capita 4,334\$

26,600 people per $\mathrm{km}^{2}$ (average)

$30 \%$ population living $500 \mathrm{~m}$ from

rail based public transport network

MUMBAI
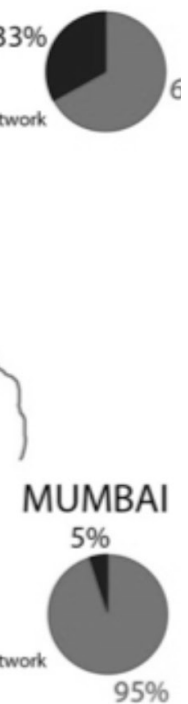

$\begin{array}{ll}\text { LEGEND: } & \text { urban area } \\ \text { rall based public transport network } & \text { Podal share in political city: }\end{array}$

Figura 62 | Estudo Acessibility in Cities: Transport and Urban Form": Comparação entre forma urbana e divisão modal 


\section{IIII}

coletivo). No meio do caminho, cidades europeias, como Berlim, apresentam divisão modal que favorece o transporte coletivo, porém, em proporções menos drásticas, (32\% para o transporte individual e $68 \%$ para o transporte coletivo) ${ }^{77}$.

Desse modo, é possível concluir que uma rede de vias expressas nunca seria capaz de resolver sozinha a problemática da mobilidade urbana de uma cidade tradicional densa e consolidada, como se imaginava desde a década de 1930, nos EUA. Fica clara, portanto, a relação de interdependência existente entre o modelo de moradia de subúrbio e o automóvel. Por conta da grande quantidade de espaço que ambos exigem, apenas juntos esses dois pilares do "sonho americano" foram capazes de criar um modelo alternativo de urbanismo para o século XX. O aumento da taxa de motorização das cidades norte-americanas não só possibilitou o processo de descentralização urbana em direção ao subúrbio; o espraiamento urbano também foi fundamental para viabilizar o automóvel individual como principal meio de transporte urbano. Se não fosse pela suburbanização em larga escala, o automóvel nunca teria se tornado o principal modal de transporte dos Estados Unidos, pois o trânsito entraria em colapso em meio à densidade do modelo de cidade tradicional. 


\subsection{PERSPECTIVAS}

Mesmo não sendo a principal forma de se enfrentar os dilemas da questão da mobilidade urbana, vias expressas - dentro da sua condição de não-lugares - são fundamentais dentro do funcionamento das metrópoles contemporâneas. Que perspectivas restam aos arquitetos para que seja possível tornar tais estruturas menos nocivas e mais integradas ao ambiente das cidades?

Stan Allen em seu ensaio "Infrastructure Urbanism", de 1999, apela aos arquitetos norte-americanos que voltem a se dedicar aos projetos de infraestrutura dos quais se afastaram no momento onde justamente elas foram mais construídas ${ }^{78}$. Inserido no debate arquitetônico norte-americano, Allen acredita que ao trabalhar nos projetos de infraestrutura, os arquitetos devem se dedicar a trabalhar a "complexidade do real", lidando com a grande escala escapando das "noções suspeitas" do planejamento urbano e do "ego heroico do arquiteto individual" 79 . Para Allen, os arquitetos seriam capazes de trabalhar, ao mesmo tempo, com "variáveis culturais e sociais assim como com materiais físicos, e a capacidade da arquitetura de significar é uma ferramenta disponível para o arquiteto trabalhando na cidade" 80 .

Manuel de Solà-Morales segue caminho semelhante, apostando nas possibilidades que tem a materialidade das construções urbanas na definição dos lugares. Em seu livro "De Cosas Urbanas", de 2008, acrescenta à leitura da urbanidade uma abordagem que vai além das questões de convívio, partindo para o seu aspecto tectônico, uma "urbanidade ligada às coisas":

"A urbanidade resulta da articulação de coisas urbanas, que não dependem da função ou atividade, mas da matéria (...). Matéria contínua do espaço construído" ${ }^{81}$

Sua hipótese parte da ideia de que a constituição física do lugar - subjugada pelo urbano do capitalismo monopolista através da criação dos não-lugares - é fundamental, talvez até mais do que as frugais relações sociais da supermodernidade, para que possa haver urbanidade no espaço urbano.

"Para a sociologia, de Georg Simmel a Francois Ascher, o caráter urbano reside naqueles espaços, artificiais e públicos, que resultam especialmente propícios às práticas sociais coletivas. No entanto, não falamos aqui dessas

\footnotetext{
78 ALLEN, 1999 : p. 51.

79 Ibid.: p. 52.

80 Ibid.: p. 53.

81 "La urbanidad resulta de la articulación de cosas urbanas, que no depende de las funciones o la actividad, sino de la materia (...).materia continua del espacio construido" SOLÀ-MORALES: 2008, p. 147.
} 
urbanidades (...). A urbanidade resulta da articulação de coisas urbanas, que não depende das funções ou da atividade, mas sim da matéria de muros e esquinas, em desníveis e fachadas, em calçadas, passeios, janelas, portais e vitrines, em rampas e semáforos, em alinhamentos e recuos (...)" 82

Para entender melhor a "busca de urbanidade nas coisas" de Solà-Morales, vale remeter ao conceito de "lugar" de Heidegger em seu trabalho seminal "Construir, Habitar, Pensar". Para o filósofo, as coisas são determinantes na definição dos lugares, já que a essência do lugar surge a partir da sua leitura. Por sua vez, para Heidegger, é a partir dos lugares que se organizam os espaços: "Os espaços que percorremos diariamente são arrumados pelos lugares, cuja essência se fundamenta nesse tipo de coisa que chamamos de coisas construídas" ${ }^{83}$, ou como colocaria Solà-Morales, "coisas urbanas".

Quanto ao desenho das infraestruturas, olhar para sua inserção no entorno parece fundamental: "diz-se às vezes que a infraestrutura deve levar em conta o entorno, quando quiçá esse entorno seja frequentemente mais importante e mais difícil que a própria infraestrutura". Uma saída, de acordo com o arquiteto, passa pela criação de relações entre as diversas atividades e escalas urbanas. Ao contrário do que propunham as primeiras vias expressas e o modernismo de Le Corbusier, Solà-Morales propõe que as diferentes escalas de circulação estabeleçam relações, que pelo menos se entreolhem, como elementos diferentes, mas complementares:

"Atuar sobre a cidade não é resolver problemas: é clarificar e adicionar ambiguidade a uma só vez, para tornar presente a grande riqueza do que significam os lugares. Criar lugar onde antes não havia. Introduzir escalas de referência imprevistas. Aproveitar qualquer chamada aos sentidos para aumentar a significação mental do lugar. (...) A condição estática ou pausada dos espaços atravessados participa da visão do movimento e das sensações de conexão e interdependência que sua presença sugere. Por isso costumo considerar muito positivo o reforço dessa visão mútua entre vias e passeios, mediante seu desdobramento em níveis distintos onde um se constitui no espetáculo do outro, desde onde, ao passear, também se contemplam os automóveis e, ao circular, se observam os passeios, constituídos em coisas diferentes e complementares, em matérias distintas de urbanidade."

Ademais, as diversas "escalas" presentes na "cidade" e no "urbano" devem ser contempladas simultaneamente no desenvolvimento de um projeto urbano:

"Estabelecer a continuidade das diferenças, valorizando seus tamanhos, mover-se na simultaneidade das escalas (quilómetro e centímetros visto de uma só vez), apreciar os cruzamentos como pontos vitais e comprimentos como adjetivos atributos são práticas essenciais do projeto urbano" ${ }^{84}$.

82 SOLÀ-MORALES Apud. HEREÑÚ, 2016: p. 83.

83 HEIDEGGER: 2006, p. 135-6.

84 "Estabelecer la continuidad de las diferencias valorando sus tamaños, moverse en la simultaneidad de las escalas (el kilómetro y el centímetro vistos a lá vez), apreciar las intersecciones como puntos vitales y las longitudes como atributos adjetivos son prácticas imprescindibles del proyecto urbano" SOLÀ-MORALES: 2008, p. 18. 
Por isso, Solà-Morales defende que devemos olhar com atenção para a matéria existente no urbano, para que dela seja possível tirar algum proveito:

"É o material da epiderme urbana que ensina suas características e diferenças, seu peso, forma, textura e forma. Sua morfologia e tectônica. Mas é preciso olhar para eles com insistência, com atenção o suficiente para nos revelem, como explica Jacques Derrida, as suas respostas escondidas, as suas cavernas" ${ }^{85}$.

"A atenção para as coisas urbanas é o que nos permite fazer da 'quantidade' urbana traduzida em variedade o principal adjetivo do território metropolitano (...). Coisas urbanas onde reconhecer a energia da urbanidade atual." ${ }^{86}$.

Para a realização dessa leitura, o próprio Solá-Morales, com seu olhar propositivo, já aponta uma alternativa afirmando que é possível atingir a totalidade através do fragmento. Segundo ele, um projeto urbano para ser efetivo precisa ser concentrado, pontual, limitado em seu tempo e espaço de intervenção, mas manter-se aberto e extenso em suas influências ${ }^{87}$.

Solà-Morales, assim como Koolhaas, conscientes dessa condição da cidade contemporânea, - cada um à sua maneira - tentam preservar certo otimismo. Defensores da congestão e complexidade como potenciais geradores de urbanidade, ambos apontam para a resignação como ferramenta de projeto. Koolhaas coloca de modo profético que "a cidade contemporânea será um manifesto retroativo em prol da beleza ainda não reconhecida da paisagem urbana do final do século XX" ${ }^{\prime 88}$, enquanto Solà-Morales adiciona: "a cidade contemporânea não é mais feia a cada dia: é cada dia mais rica" ${ }^{89}$. Portanto, caberia a nós, arquitetos e urbanistas, aceitar o urbano como ele é, concentrando a nossa ação no possível, no palpável, na intervenção no espaço existente, sem negar a inexorável concretude das vias expressas.

85 "Es la materia de la epidermis urbana la que nos enseña sus características y sus diferencias, su peso, forma, textura y formato. Su morfología y su tectónica. Pero hay que mirarlas con insistencia, con suficiente atención para que nos revelen, como ya explicaba Jacques Derrida, sus respuestas escondidas, sus cavernas" SOLÀ-MORALES: 2008, p. 24.

86 "La atención a las cosas urbanas es la que nos permite hacer de la 'cantidad' urbana traducida en variedad el principal adjetivo del territorio metropolitano (...). Cosas urbanas en las que reconocer la energía de la urbanidad actual." SOLÀ-MORALES: 2008, p. 27.

87 lbid., p. 153.

88 KOOLHAAS, Apud. NESBITT: 2006, p. 357.

89 SOLÀ-MORALES, 2008: p. 26. Trad. Livre. 



\section{REFERÊNCIAS BIBLIOGRÁFICAS}

ADORNO, T. Progresso. Revista Lua Nova, no27, p. 217-236, 1992.

ADORNO, T.; HORKHEIMER, M. A indústria cultural: o iluminismo como mistificação de massas. In: LIMA, L. C. Teoria da cultura de massa. São Paulo: Paz eTerra, 2002. $202 p$.

ALLEN, S. Points+lines: diagrams and projects for the city. Nova lorque: Princeton Architectural Press, 1999.

ANELLI, R. Plano conformação da base da metrópole: redes de mobilidade paulistanas. Porto Alegre: Marca Visual, 2011.

ANELLI, R.; SEIXAS, A. R. O peso das decisões: o impacto das redes de infraestrutura no tecido urbano. In: Caminhos do elevado: memórias e projetos. São Paulo: Secretaria Municipal de Planejamento/Imprensa oficial do Estado de São Paulo, 2008. p. 59-74.

ARGAN, G. C. Arte moderna: do iluminismo aos movimentos contemporâneos. Traducao Denise Bottmann; Federico Carotti. São Paulo: Companhia das Letras, 1992.

ARGAN, G. C. História da arte como história da cidade. Tradução Pier Luigi Cabra. São Paulo: Martins Fontes, 1993.

AUGE, M. Não-lugares: introdução a uma antropologia da supermodernidade. Campinas: Papirus, 2010.

AUGUSTO, C. Maluf diz que trânsito é progresso. Folha de S. Paulo, 29 fev. 1996.

BANHAM, R. Teoria e projeto na primeira era da máquina. São Paulo: Perspectiva, 2003.

BANHAM, R. Los Angeles: the architecture of four ecologies. Oakland: University of California Press, 2009.

BOTTLES, S. L. Los Angeles and the automobile: the making of the modern city. Oakland: University of California Press, 1987. 
BRAGA, M. L. de A. Infraestrutura e projeto urbano. Tese de Doutorado. Universidade de São Paulo, 2006.

BROWN, J. Building Autopia: The Devellopment of Urban Freeway Planning in the Pre-Interstate Era. 2005a. Disponível em: <http://citeseerx.ist.psu.edu/viewdoc/ download?doi=10.1.1.536.545\&rep=rep1\&type=pdf>. Acesso em: 7 jul. 2016.

BROWN, J. A Tale of Two Visions: Harland Bartholomew, Robert Moses, and the Development of the American Freeway. Journal of Planning History, v. 4, n. 1, p. 3-32, 2 jan. $2005 b$

BROWN, J.; MORRIS, E.; TAYLOR, B. Paved with Good Intentions: Fiscal Politics, Freeways, and the 20th Century American City. Access Magazine, v. 35, p. 30-37, out. 2009.

CABRAL, G. F. O utopista e a autopista: os viadutos sinuosos habitáveis de Le Corbusier e suas origens brasileiras (1929-1936). Arqtexto. n. 9 (2006), p. 54-75, 2006. Disponível em: <http://www.ufrgs.br/propar/publicacoes/ARQtextos/PDFs_revista_9/9_Gilberto\%20 Flores\%20Cabral.pdf>. Acesso em: 8 jun. 2016.

CAMPOS, C. M. Os rumos da cidade: urbanismo e modernização em São Paulo. São Paulo, SP: Editora SENAC São Paulo, 2000.

CAMPOS FILHO, C. M. Um desenho para São Paulo o corredor metropolitano como estrutura urbana aberta para a Grande São Paulo. Tese de Doutorado. Universidade de São Paulo, São Paulo, 1972.

CARO, R. A. The power broker Robert Moses and the fall of New York. New York: Vintage Books, 1975.

CHOAY, F. L'Urbanisme Haussmannien et ses Principes. In: HAUSSMANN, G. E. Mémoires: édition intégrale. Paris: Seuil, 2000.

CHOAY, F. O urbanismo: utopias e realidades, uma antologia. São Paulo: Perspectiva, 2005 (1964).

COHEN, J. 0 futuro da arquitetura desde 1889. São Paulo: Cosac \& Naify, 2013.

CONN, S. Americans against the city: anti-urbanism in the twentieth century. Oxford: Oxford University Press, 2014.

COSTA, L. Lucio costa: registro de uma vivência. São Paulo, Brasil: Empresa das Artes, 1995.

CURTIS, W. J. R. Le corbusier: ideas and forms. London; New York: Phaidon Press, 1994. 
DIMENTO, J. F. C.; ELLIS, C. Changing lanes: visions and histories of urban freeways. Cambridge: The MIT Press, 2014.

DUPAS, G. O mito do progresso. Novos Estudos - CEBRAP, n. 77, p. 73-89, mar. 2007.

EQUIPE ASPLAN / DALY-MONTREAL /W. SMITH. Plano Urbanístico Básico - Circulação e Transportes: Recomendações. Revista Engenharia, n. no49, p. 11-19, dez. 1970.

FABRIS, A. Futurismo: uma poética da modernidade. São Paulo: Editora Perspectiva, 1987.

FLORENCE, L. R. A. Mecanismo e paisagem: Reyner Banham e a América. Dissertação de mestrado. Universidade de São Paulo, 2014.

FOSTER, M. S. From streetcar to superhighway: American city planners and urban transportation, 1900-1940. Philadelphia: Temple University Press, 1981.

FOSTER, M. S. Nation on wheels: the automobile culture in America since 1945. Belmont, CA: Thomson, Wadsworth, 2003.

FRANCO, F. de M. A construção do caminho a estruturação da metrópole pela conformação técnica das várzeas e planícies fluviais da bacia de São Paulo. Tese de Doutorado. Universidade de São Paulo, São Paulo, 2005.

GASPERINI, G. C. Arquitetura e transportes. Tese de Doutorado. Universidade de São Paulo, São Paulo, 1972.

GEDDES, N. B. Magic motorways. [s.I.] Read Books Ltd, 2013.

GIEDION, S. Espaço, tempo e arquitetura o desenvolvimento de uma nova tradição. São Paulo: Martins Fontes, 2004.

GIUCCI, G. A vida cultural do automóvel: percursos da modernidade cinética. Rio de Janeiro: Civilização Brasileira, 2004.

HALL, P. Cidades do amanhã uma história intelectual do planejamento e do projeto urbanos no século XX. Tradução Pérola De Carvalho. São Paulo: Perspectiva, 2013 (1988).

HALPRIN, L. Freeways. Nova lorque: Reinhold Publishing Corporation, 1966.

HARVEY, D. Condição pós-moderna uma pesquisa sobre as origens da mudança cultural. São Paulo: Loyola, 1993.

HARVEY, D. Paris, capital da modernidade. São Paulo: Boitempo, 2015. 
HEIDEGGER, M. Construir, Habitar, Pensar. In: Ensaios e Conferências / Martin

Heidegger. Tradução Emanuel Carneiro Leão; Gilvan Fogel; Márcia Schuback.

Petrópolis: Vozes, 2006.

HERCE, M. O negócio da cidade. Rio de Janeiro: Mauad Editora Ltda, 2015.

HEREÑÚ, P. Sentidos do Anhangabaú. 2007. Dissertação de mestrado. Universidade de São Paulo, São Paulo, 2007.

HEREÑÚ, P. Arquitetura da mobilidade e espaço urbano. Tese de Doutorado.

Universidade de São Paulo, São Paulo, 2016.

IDOETA, I. São Paulo vista do alto 75 anos de aerofotogrametria. São Paulo: Editora Érica, 2004.

JAMESON, F. A virada cultural: reflexões sobre o pós-modernismo. Tradução Carolina Araújo. Rio de Janeiro: Civilização Brasileira, 2006.

JORDAN, D. P. Haussmann and haussmannisation: the legacy for Paris. French Historical Studies, v. 27, n. 1, p. 87-113, 2004.

KAY, J. H. Asphalt nation: how the automobile took over America, and how we can take it back. Oakland: University of California Press, 1997.

KOOLHAAS, R. S M L XL. New York: Monacelli Press, 1995.

KOOLHAAS, R. Delirious NewYork: a retroactive manifesto for Manhattan. New York: Monacelli Press, 1997 (1978).

KOOLHAAS, R. Três textos sobre a cidade. Barcelona: Gustavo Gili, 2013.

LAGONEGRO, M. A. Metrópole sem metrô transporte público, rodoviarismo e populismo em são paulo (1955-1965). Tese de Doutorado. Universidade de São Paulo, 2003.

LAY, M. G.; VANCE, J. E. Ways of the world: a history of the world's roads and of the vehicles that used them. [s.I.] Rutgers University Press, 1992.

LE CORBUSIER. La ville radieuse. eléments d'une doctrine d'urbanisme pour I'équipement de la civilisation machiniste. Paris: Editions Vincent, Fréal \& Cie, 1933.

LE CORBUSIER. Le corbusier the complete architecture works. London: Thames, 1966. v. 2

LE CORBUSIER. Os três estabelecimentos humanos. São Paulo: Perspectiva, 1979. 
LE CORBUSIER. Urbanismo. São Paulo: WMF M. Fontes, 1992.

LE CORBUSIER. Precisões sobre um estado presente da arquitetura e do urbanismo. São Paulo: Cosac \& Naify, 2004.

LEFEBVRE, H. O direito à cidade. São Paulo: Moraes, 1991.

LEWIS, T. Divided highways: building the interstate highways, transforming American life. Ithaca: Cornell University Press, 2013.

LÖWY, M.; VARIKAS, E. A crítica do progresso em Adorno. Lua Nova: Revista de Cultura e Política, n. 27, p. 201-216, dez. 1992.

MACKAYE, B.; MUMFORD, L. Townless highways for the motorist - a proposal for the automobile age. Harpers Magazine, p. 347-356, ago. 1931.

MAIA, F. P. Estudo de um plano de avenidas para a cidade de São Paulo. São Paulo: Melhoramentos, 1930

MAIA, P. Os melhoramentos de São Paulo. São Paulo: Prefeitura da Cidade de São Paulo, 1945.

$M A R X, K . O$ capital - crítica da economia política. livro primeiro - o processo de produção do capital. Tradução Reginaldo Sant'Anna. Rio de Janeiro: Bertrand Brasil, 1989. v. Volume I

MARX, K.; ENGELS, F. Manifesto do partido comunista.

MCSHANE, C. Down the asphalt path. New York: Columbia University Press, 1995.

MEYER, R. M. P. Metrópole e urbanismo São Paulo anos 50. Tese de Doutorado. Universidade de São Paulo, São Paulo, 1991.

MEYER, R. M. P. Mobilidade viária versus contexto urbano. In: SCHICCH, M. C.; BENFATTI, D. (Ed.). Urbanismo: dossiê São Paulo - Rio de Janeiro. Campinas: PUCCAMP/PROURB, 2004.

MOOS, S. von. Le Corbusier I'architecte et son mythe. Paris: SIHorizons de France, 1971.

MOOS, S. von. Le Corbusier, elements of a synthesis. Cambridge, Mass: MIT Press, 1979.

MORAGLIO, M. Real Ambition or Just Coincidence? The Italian Fascist Motorway Project in Inter-war Europe. Journal of Transport History, p. 168-82, fev. 2009. 
MOSES, R. Programa de melhoramentos públicos para a cidade de São Paulo. New York: Internat Basic Economy Corporation, 1950.

MUMFORD, L. Highway and the city. New York: The New American Library, 1963.

MUZI, A. M. Revisão urbanística das perimetrais: as avenidas perimetrais da área central como suporte para o transporte público de São Paulo. Dissertação de mestrado. Universidade de São Paulo, 2014.

NESBITT, K. Uma nova agenda para a arquitetura: antologia teórica 1965-1995. Sao Paulo: Cosac Nsify, 2006.

NORTON, P. D. Fighting traffic: the dawn of the motor age in the American city. Cambridge: MIT Press, 2008.

PEREIRA, J. R. A. Le Corbusier's Dioramas. In: Cuadernos de Proyectos Arquitectónicos. Madri: Universidad Politécnica de Madrid, 2013. 0p. 133-135.

REIS FILHO, N. G. Memória do transporte rodoviário. São Paulo: CPA, 1997.

RODE, P.; FLOATER, G. Acessibility in cities: transport and urban form. The New Climate Economy, p. 1-61, 2014.

RODRIGUES, G. P. Vias públicas: tipo e construção em São Paulo (1898-1945). Dissertação de mestrado. Universidade de São Paulo, 2008.

ROSE, M. H. Interstate: express highway politics, 1939-1989. Knoxville: Univ. of Tennessee Press, 1990.

SÁ, T. Lugares e não lugares em Marc Augé. Tempo Social, v. 26, n. 2, p. 209-229, 1 dez. 2014.

SAKAGUCHI, M. A. Da medicina ao urbanismo, as origens do primado da mobilidade. Dissertação de Mestrado. Universidade de São Paulo, 1998.

SAKAGUCHI, M. A. O espaço das infra-estruturas da cidade bela à cidade eficiente. Tese de doutorado. Universidade de São Paulo, 2005.

SALVI, A. E. Cidadelas da civilização políticas norte-americanas no processo de urbanização brasileira com ênfase na metropolização paulistana dos anos 1950 a 1969. Tese de Doutorado. Universidade de São Paulo, 2005.

SCHIPPER, F. Driving Europe: building Europe on roads in the twentieth century. Amsterdam: Amsterdam University Press, 2008.

SEELY, B. E. Building the American highway system: engineers as policy makers. 
Philadelphia: Temple University Press, 1987.

SEIXAS, A. R. A cidade e a mobilidade na era do automóvel: a obra de

Colin Buchanan (1958-1966). Tese de Doutorado. Universidade de São Paulo, 2010.

SHELTON, T. Automobile utopias and traditional urban infrastructure: visions of the coming conflicct, 1925-1940. Traditional Dwellings and Settlements Review, v. 22, n. 1, p. 14-14, 2010.

SIMMEL, G. As grandes cidades e a vida do espírito. In: CHOAY, F. O urbanismo: utopias e realidades, uma antologia. São Paulo: Perspectiva, 2005.

SOLÀ-MORALES, I. de. Territorios. Barcelona: Gustavo Gili, 2002.

SOLÀ-MORALES, M. de. De cosas urbanas. Barcelona: Editorial Gustavo Gili, SL, 2008. SOMEKH, N.; CAMPOS, C. M. (ed.). A cidade que não pode parar: planos urbanísticos de São Paulo no século XX. São Paulo: Mack Pesquisa, 2008.

SWIFT, E. The big roads: the untold story of the engineers, visionaries, and trailblazers who created the American superhighways. Boston: Houghton Mifflin Harcourt, 2011.

TAFURI, M. Modern architecture. New York: HNAbrams, 1979.

TEITZ, M. B. Melvin Webber and the "Nonplace Urban Realm". ACCESS Magazine, 1 jan. 2007. Disponível em: <http://www.accessmagazine.org/articles/special-issue/me/vin-webber-and-the -nonplace-urban-realm/>. Acesso em: 23 fev. 2017.

TOLEDO, B. L. de. Prestes maia e as origens do urbanismo moderno em São Paulo. São Paulo: Empresa das Artes, 1996.

TOTA, A. P. O imperialismo sedutor a americanização do Brasil na época da segunda guerra. São Paulo: Companhia das Letras, 2005.

UNITED STATES PUBLIC ROADS ADMINISTRATION. Toll roads and free roads. Washington, D.C.: U. S. Government print office, 1939.

UNITED STATES PUBLIC ROADS ADMINISTRATION. Interregional highways. Washington, D.C.: U.S. Government Printing Office, 1944.

VASCONCELLOS, E. A. de. Transporte urbano nos países em desenvolvimento: reflexões e propostas. São Paulo: Annablume, 1996.

VASCONCELLOS, E. A. de. Circular é preciso, viver não é preciso: a história do trânsito na cidade de São Paulo. São Paulo: Annablume, 1999. 
VASCONCELLOS, E. A. Transporte urbano, espaço e equidade: análise da políticas públicas. São Paulo: Annablume, 2001.

VENTURI, R.; BROWN, D. S.; IZENOUR, S. Aprendendo com Las Vegas: o simbolismo (esquecido) da forma arquitetônica. São Paulo: Cosac \& Naify, 2003.

VILLAÇA, F. Uma contribuição para a história do planejamento urbano no Brasil. In: DEÁK, C.

(Ed.). O processo de urbanização no Brasil. São Paulo: EDUSP, FUPAM/EDUSP, 1999.

WEINER, E. Urban transportation planning in the united states: history, policy, and practice. [s.I.] Springer Science \& Business Media, 2012.

WEINGROFF, R. Edward M. Bassett The Man Who Gave us “Freeway" - General Highway History. Disponível em: <https://www.fhwa.dot.gov/infrastructure/freeway.cfm>. Acesso em: 19 out. 2016a.

WEINGROFF, R. A Vast System of Interconnected Highways: Before the

Interstates. Disponível em: <http://www.fhwa.dot.gov/highwayhistory/vast.pdf>. Acesso em: 25 out. $2016 b$.

WELLS, C. W.; CRONON, W. Car country: an environmental history. Seattle: University of Washington Press, 2014.

WHITE, M. G.; WHITE, L. The intellectual versus the city, from Thomas Jefferson to Frank Lloyd Wright. Cambridge: Harvard University Press, 1962.

WILHEIM, J. São Paulo, metrópole 65 subsídios para seu plano diretor. São Paulo: Difusão Européia do Livro, 1965.

X BienAl de ARQUitetura de SÃO PAUlO. Catálogo da Exposição. Revista Monolito, v. 17, p. 16-149, 2013.

ZIEGLER, V. Les Chemins de Le Corbusier de I'autodrome à I'autoroute. In: TSIOMIS, Y. (Ed.). Le Corbusier Rio de Janeiro 1929, 1936. Rio de Janeiro: Centro de Arquitetura e Urbanismo do Rio de Janeiro/Prefeitura da Cidade do Rio de Janeiro, 1998.

ZMITROWICZ, W.; BORGHETTI, G. Avenidas 1950-2000: 50 anos de planejamento da cidade de São Paulo. São Paulo: EdUSP : Pró-Reitoria de Cultura e Extensão Universitária, 2009. 


\section{LISTA DE IMAGENS}

Contracapa | Joseph Stashkevetch - Los Angeles, 1997-1999.

Fonte: Joseph Stashkevetch: los angeles freeways. Disponível em: <http://www. stashkevetch.com/drawings/?c=los-angeles-freeways>. Acesso em: 6 mar. 2017.

Epígrafe capítulo 1 | Laerte: Manual do Minotauro.

Fonte: Manual do Minotauro: 15-03-2012. Disponível em: <http://manualdominotauro. blogspot.com.br/2012/04/15-03-2012.html>. Acesso em: 5 mar. 2017.

Epígrafe capítulo 5 | Crumb: Crumb: A Street History of America

Fonte: Click Here For Closeup Of R. Crumb's "A Short History Of America." - KUNSTLER.

Disponível em: <http://kunstler.com/clusterfuck-nation/click-here-for-closeup-of-r-crum bs-a-short-history-of-america/>. Acesso em: 5 mar. 2017.

Figura 1 | Jean Béraud | Boulevard Piossonniére em automne, 1885

Fonte: Boulevard Poissen automne.jpg. Disponível em: <http://impressionistsgallery. co.uk/artists/Artists/abc/Beraud/pictures/Boulevard\%20Poissen\%20automne.jpg>. Acesso em: 5 mar. 2017.

Figura 2 | Memorial dedicado às crianças vítimas de acidente de trânsito, em Baltimore, 1922.

Fonte: NORTON, P. D. Fighting traffic: the dawn of the motor age in the American city. Cambridge: MIT Press, 2008, p. 42.

Figura 3 | Sacrifice to the Modern Moloch. Charge publicada no St. Louis Star, em 1926

Fonte: NORTON, P. D. Fighting traffic: the dawn of the motor age in the American city. Cambridge: MIT Press, 2008, p. 28

Figura 4 | Cartaz de George Starkey para a No Accident Week de 1920: "keep the kids off the street"

Fonte: NORTON, P. D. Fighting traffic: the dawn of the motor age in the American city. Cambridge: MIT Press, 2008, p. 40.

Figura 5 | Cartaz de Harry De Bauffer, reproduzido no Milwaukee Journal, 1920. 
Fonte: NORTON, P. D. Fighting traffic: the dawn of the motor age in the American city. Cambridge: MIT Press, 2008, p. 41.

Figura 6 | Cartaz da American Automobile Association (1927?)

Fonte: NORTON, P. D. Fighting traffic: the dawn of the motor age in the American city. Cambridge: MIT Press, 2008: p. 230.

Figura 7 | Cartaz de campanha de segurança do Chicago Motor Club, 1932.

Fonte: NORTON, P. D. Fighting traffic: the dawn of the motor age in the American city. Cambridge: MIT Press, 2008, p. 228.

Figura 8 | Chicago em 1929, antes da coordenação semafórica e proibição de estacionamento

Fonte: NORTON, P. D. Fighting traffic: the dawn of the motor age in the American city. Cambridge: MIT Press, 2008, p. 137.

Figura 9 | Chicago em 1929, depois da coordenação semafórica e proibição de estacionamento Fonte: NORTON, P. D. Fighting traffic: the dawn of the motor age in the American city. Cambridge: MIT Press, 2008, p. 137.

Figura 10 | Charge sobre o trânsito nas cidades norte-americanas, 1952.

Fonte: The Herb Block Foundation.

Figura 11 | Chicago, 1907

Fonte: CONN, S. Americans against the city: anti-urbanism in the twentieth century. Oxford: Oxford University Press, 2014, p. 16.

Figura 12 | Bronx River Parkway, sem data.

Fonte: Postcard Tour — Scarsdale Historical Society. Disponível em: <http://www.scar sdalehistoricalsociety.org/postcard-tour/\#itemld=53d3fd8fe4b00000003f5163>. Acesso em: 5 mar. 2017.

Figura 13 | Estrada nacional pavimentada com pedrisco em Ohio, 1917

Fonte: GREY, J. Improving the rutted roadDown the Road, 4 ago. 2011. . Disponível em: <https://blog.jimgrey.net/2011/08/04/improving-the-rutted-road/>. Acesso em: 5 mar. 2017. Figura 14 | Estrada pavimentada em concreto em Ohio, 1933

Fonte: GREY, J. Improving the rutted roadDown the Road, 4 ago. 2011. . Disponível em: <https://blog.jimgrey.net/2011/08/04/improving-the-rutted-road/>. Acesso em: 5 mar. 2017.

Figura 15 | Pedágio de acesso à Autostrada Milano Laghi 
Fonte: Autostrada dei Laghi - Wikipedia. Disponível em: <https://it.wikipedia.org/wiki/ Autostrada_dei_Laghi>. Acesso em: 5 mar. 2017.

Figura 16 | Autostrada Milano Laghi - cruzamento em desnível.

Fonte: Autostrada dei Laghi - Wikipedia. Disponível em: <https://it.wikipedia.org/wiki/ Autostrada_dei_Laghi>. Acesso em: 5 mar. 2017.

Figura 17 | Autobahn Alemã, 1937

Fonte: Es war einmal.......Teil 03 - ddbnews.wordpress.com. Disponível em: <https:// ddbnews.wordpress.com/es-war-einmal/es-war-einmal-teil-3/>. Acesso em: 5 mar. 2017. Figura 18 | Divulgação do empreendimento, sem data

THOMAS ADAMS. Disponível em: <http://www.kosmoid.net/planning/adams>. Acesso em: 5 mar. 2017.

Figura 19 | Frank Lloyd Wright - Broadacre City

Fonte: SHELTON, T. Automobile utopias and traditional urban infrastructure: visions of the coming conflicct, 1925-1940. Traditional Dwellings and Settlements Review, v. 22, n. 1, p. 14-14, 2010, p. 70

Figura 20 | Estudos de Encontros Viários para a Ville Radieuse

Fonte: LE CORBUSIER. La ville radieuse. eléments d'une doctrine d'urbanisme pour I'équipement de la civilisation machiniste. Paris: Editions Vincent, Fréal \& Cie, 1933, p. 167.

Figura 21 | Ville Radieuse - Cortes transversais

Fonte: LE CORBUSIER. La ville radieuse. eléments d'une doctrine d'urbanisme pour I'équipement de la civilisation machiniste. Paris: Editions Vincent, Fréal \& Cie, 1933, p. 167.

Figura 22 | Le Corbusier - Ville Radieuse, 1933

Fonte: LE CORBUSIER. La ville radieuse. eléments d'une doctrine d'urbanisme pour I'équipement de la civilisation machiniste. Paris: Editions Vincent, Fréal \& Cie, 1933, p. 130.

Figura 23 | Le Corbusier - Ville Radieuse, 1933

Fonte: LE CORBUSIER. La ville radieuse. eléments d'une doctrine d'urbanisme pour I'équipement de la civilisation machiniste. Paris: Editions Vincent, Fréal \& Cie, 1933, p. 92. 
Figura 24 | Henry Hudson Parkway,

Fonte: UNITED STATES PUBLIC ROADS ADMINISTRATION. Interregional highways: Washington, D.C.: U.S. Government Printing Office, 1944.

Figura 25 | Mapa das intervenções Haussmannianas na cidade de Paris.

Fonte: Réalisations urbaines du Second Empire à Paris - Wikipédia. Disponível em: <https://fr.wikipedia.org/wiki/R\%C3\%A9alisations_urbaines_du_Second_Empire_\% C3\%A0_Paris>. Acesso em: 5 mar. 2017.

Figura 26 | Planta de um típico "percement"

Fonte: José Ortega y Gasset: “Meditación de la Técnica” | EL BLOG DE JOSÉ FARIÑA. Disponível em: <https://elblogdefarina.blogspot.com.br/2008/05/jos-ortega-ygasset-meditacin-de-la.html>. Acesso em: 5 mar. 2017.

Figura 27 | Gustave Caillebotte | Jour de pluie à Paris, 1877

Fonte: Gustave Caillebotte - Jour de pluie à Paris.jpg - Wikimedia Commons. Disponível em: <https://commons.wikimedia.org/wiki/File:Gustave_Caillebotte_-_Jour_de_pluie_\% C3\%A0_Paris.jpg>. Acesso em: 5 mar. 2017.

Figura 28 | Camille Pissaro - Boulevard Montmartre, 1897

boulevard montmartre, afternoon sun, 1897 - Camille Pissarro - www.camille-pissarro. org. Fonte: Disponível em: <http://www.camille-pissarro.org/boulevard-montmartre,afternoon-sun,-1897.html>. Acesso em: 5 mar. 2017.

Figura 29 | H. W. Corbett: City of the Future, 1913

Fonte: The Skyscraper Museum: Future City: New York Modern. Disponível em: <http:// www.skyscraper.org/EXHIBITIONS/FUTURE_CITY/NEW_YORK_MODERN/walkthrou gh_corbett.php>. Acesso em: 5 mar. 2017.

Figura 30 | E. Hénard: Cidade Futura, 1910

Fonte: HENARD, CITIES OFTHE FUTURE. Disponível em: <http://urbanplanning.library. cornell.edu/DOCS/henard.htm>. Acesso em: 5 mar. 2017.

Figura 31 | H. W. Corbett: Proposta para Manhattan, 1923.

Fonte: The Skyscraper Museum: Future City: New York Modern. Disponível em: <http:// www.skyscraper.org/EXHIBITIONS/FUTURE_CITY/NEW_YORK_MODERN/walkthrou gh_corbett.php>. Acesso em: 5 mar. 2017.

Figura 32 | Proposta para aliviar o trânsito em Nova lorque em suas fases de implementação 
Fonte: MAIA, F. P. Estudo de um plano de avenidas para a cidade de São Paulo. São Paulo: Melhoramentos, 1930, p. 99. p. 94.

Figura 33 | Sant'Elia - La Cittá Nuova, 1914

Fonte: The Cities Science Fiction Built - Motherboard. Disponível em: <https://mother board.vice.com/en_us/article/the-cities-science-fiction-built?trk_source=recommended >. Acesso em: 5 mar. 2017.

Figura 34 | Le Corbusier - Plan Voisin, 1925

Fonte: LE CORBUSIER. Le corbusier the complete architecture works. London: Thames, 1966. v. 2

Figura 35 | Le Corbusier - Proposta para São Paulo, 1929

Fonte: LE CORBUSIER. Precisões sobre um estado presente da arquitetura e do urbanismo. São Paulo: Cosac \& Naify, 2004.

Figura 36 | Le Corbusier - Proposta para São Paulo, 1929

Fonte: LE CORBUSIER. La ville radieuse. eléments d'une doctrine d'urbanisme pour I'équipement de la civilisation machiniste. Paris: Editions Vincent, Fréal \& Cie, 1933, p. 225

Figura 37 | Norman Bell Guedes - Futurama, 1939

Fonte: GEDDES, N. B. Magic motorways. [s.I.] Read Books Ltd, 2013.

Figura 38 | Norman Bell Guedes - Futurama, 1939

Fonte: GEDDES, N. B. Magic motorways. [s.I.] Read Books Ltd, 2013.

Figura 39 | Norman Bell Guedes - Futurama, 1939

Fonte: GEDDES, N. B. Magic motorways. [s.I.] Read Books Ltd, 2013.

Figura 40 | Detroit Rapid Transit Commission - Detroit Superhighway System, 1928

Fonte: DIMENTO, J. F. C.; ELLIS, C. Changing lanes: visions and histories of urban freeways. Cambridge: The MIT Press, 2014, : p.19.

Figura 41 | Detroit Rapid Transit Commission - Detroit Superhighway System, 1928

Fonte: Discuss Detroit: Detroit Expressway Planning circa 1945. Disponível em: <http:// wWw.atdetroit.net/forum/messages/6790/43221.html?1160845287>. Acesso em: 5 mar. 2017.

Figura 42 | Woodward Avenue, Detroit 
Fonte: The "super-highways" of Detroit. Disponível em: <http://www.aaroads.com/ forum/index.php?topic=8737.0 > . Acesso em: 5 mar. 2017.

Figura 43 | Plano de Fritz Malcher para Havana, 1928

Fonte: MAIA, F. P. Estudo de um plano de avenidas para a cidade de São Paulo. São Paulo: Melhoramentos, 1930, p. 99.

Figura 45 | Report on a Thoroughfare Plan for Boston, 1930

Fonte: DIMENTO, J. F. C.; ELLIS, C. Changing lanes: visions and histories of urban freeways. Cambridge: The MIT Press, 2014, p. 41.

Figura 46 | Boston - Central Artery, 1972

Fonte: Boston From The Air Pictures | Getty Images. Disponível em: <http://www. gettyimages.com/detail/news-photo/aerial-view-of-downtown-and-the-central-arteryboston-news-photo/138772837\#aerial-view-of-downtown-and-the-central-arteryboston-massachusetts-picture-id138772837>. Acesso em: 5 mar. 2017.

Figura 47 | Boston - The Big Dig, 2007

Fonte: With The Central Artery Gone, Walking And Driving Through Boston Is New Experience Pictures | Getty Images. Disponível em: <http://www.gettyimages.com/ detail/news-photo/walking-and-driving-through-boston-is-an-entirely-new-newsphoto/111902145\#walking-and-driving-through-boston-is-an-entirely-new-experiencewith-picture-id111902145>. Acesso em: 5 mar. 2017.

Figura 48 | West Side Elevated Highway, 1944

Fonte: DIMENTO, J. F. C.; ELLIS, C. Changing lanes: visions and histories of urban freeways. Cambridge: The MIT Press, 2014, p. 37.

Figura 49 | proposta para freeway elevada através de Manhattan, 1946

Fonte: DIMENTO, J. F. C.; ELLIS, C. Changing lanes: visions and histories of urban freeways. Cambridge: The MIT Press, 2014, p. 87.

Figura 50 | Toll Roads and Free Roads, 1939 - Estudos de traçado viário para a cidade de Baltimore

Fonte: UNITED STATES PUBLIC ROADS ADMINISTRATION. Toll roads and free roads. Washington, D.C.: U. S. Government print office, 1939.

Figura 51 | Toll Roads and Free Roads - Via Expressa Urbana

Fonte: UNITED STATES PUBLIC ROADS ADMINISTRATION. Toll roads and free roads. 
Washington, D.C.: U. S. Government print office, 1939.

Figura 52 | Interregional Highways, 1944 - Mapa do sistema de vias expressas com gráfico de demanda.

Fonte: UNITED STATES PUBLIC ROADS ADMINISTRATION. Interregional highways: Washington, D.C.: U.S. Government Printing Office, 1944.

Figura 53 | Interregional Highways, 1944 - Entrada das vias inter-regionais em cidades de tamanhos diferentes.

Fonte: UNITED STATES PUBLIC ROADS ADMINISTRATION. Interregional highways: Washington, D.C.: U.S. Government Printing Office, 1944.

Figura 54 | Interregional Highways, 1944 - proposta de via elevada.

Fonte: UNITED STATES PUBLIC ROADS ADMINISTRATION. Interregional highways: Washington, D.C.: U.S. Government Printing Office, 1944

Figura 55 | Proposta de Via Expressa para Los Angeles, 1937.

Fonte: DIMENTO, J. F. C.; ELLIS, C. Changing lanes: visions and histories of urban freeways. Cambridge: The MIT Press, 2014, p. 74.

Figura 56 | Pennsylvania Turnpike, 1942

Fonte: File:Pennsylvania Turnpike in 1942.jpg - Wikimedia Commons. Disponível em: <https://commons.wikimedia.org/wiki/File:Pennsylvania_Turnpike_in_1942.jpg>. Acesso em: 5 mar. 2017.

Figura 57 | Santa Monica Freeway em construção, Los Angeles, 1961

Fonte: Before the "Carmageddon": A Photographic Look at the Construction of 5 So Cal Freeways | KCET. Disponível em: <https://www.kcet.org/shows/lost-la/before-the-carm ageddon-a-photographic-look-at-the-construction-of-5-socal-freeways>. Acesso em: 5 mar. 2017.

Figura 58 | Santa Monica Freeway (Interstate 10) , Los Angeles, 1964

Fonte: Before the "Carmageddon": A Photographic Look at the Construction of 5 So Cal Freeways | KCET. Disponível em: <https://www.kcet.org/shows/lost-la/before-the-carm ageddon-a-photographic-look-at-the-construction-of-5-socal-freeways>. Acesso em: 5 mar. 2017.

Figura 59 | Santa Monica Freeway (Interstate 10) , Los Angeles, 1970

Fonte: Before the "Carmageddon": A Photographic Look at the Construction of 5 So 
Cal Freeways | KCET. Disponível em: <https://www.kcet.org/shows/lost-la/before-the-carm ageddon-a-photographic-look-at-the-construction-of-5-socal-freeways $>$. Acesso em: 5 mar. 2017.

Figura 60 | Elvis Presley com seu Cadillac

Fonte: A coleção de carros de Elvis Presley |VEJA.com. Disponível em: <http://veja. abril.com.br/galeria-fotos/a-colecao-de-carros-de-elvis-presley/>. Acesso em: 5 mar. 2017.

Figura 62 | Obras da Cross Bronx Expressway, 1957

Fonte: Minhocão || Cross Bronx : Photo. Disponível em: <http://minhocross.tumblr. com/image/128727517214>. Acesso em: 5 mar. 2017.

Figura 64 | Duas fotos aéreas do Parque Dom Pedro II, em São Paulo: 1968 e 1974, após a construção da Ligação Leste-Oeste e da Avenida do Estado.

Fonte: IDOETA, I. São Paulo vista do alto 75 anos de aerofotogrametria. São Paulo: Editora Érica, 2004.

Figura 63 | Corredor Leste-Oeste, trecho sobre o Tamanduateí

Fonte: GASPERINI, G. C. Arquitetura e transportes. Tese de Doutorado. Universidade de São Paulo, São Paulo, 1972, p.12.

Figura 65 | Forma urbana e divisão modal

Fonte: RODE, P.; FLOATER, G. Acessibility in cities: transport and urban form. The New Climate Economy, p. 1-61, 2014, p. 06. 
